\title{
ЕЖКЕМЕСЯЧНЫЙ НАУЧНО-ТЕХНИЧЕСКИЙ
}

ИПРОИЗВОДСТВЕННО-ЭКОНОМИЧЕСКИЙ ЖУРРНАЛ
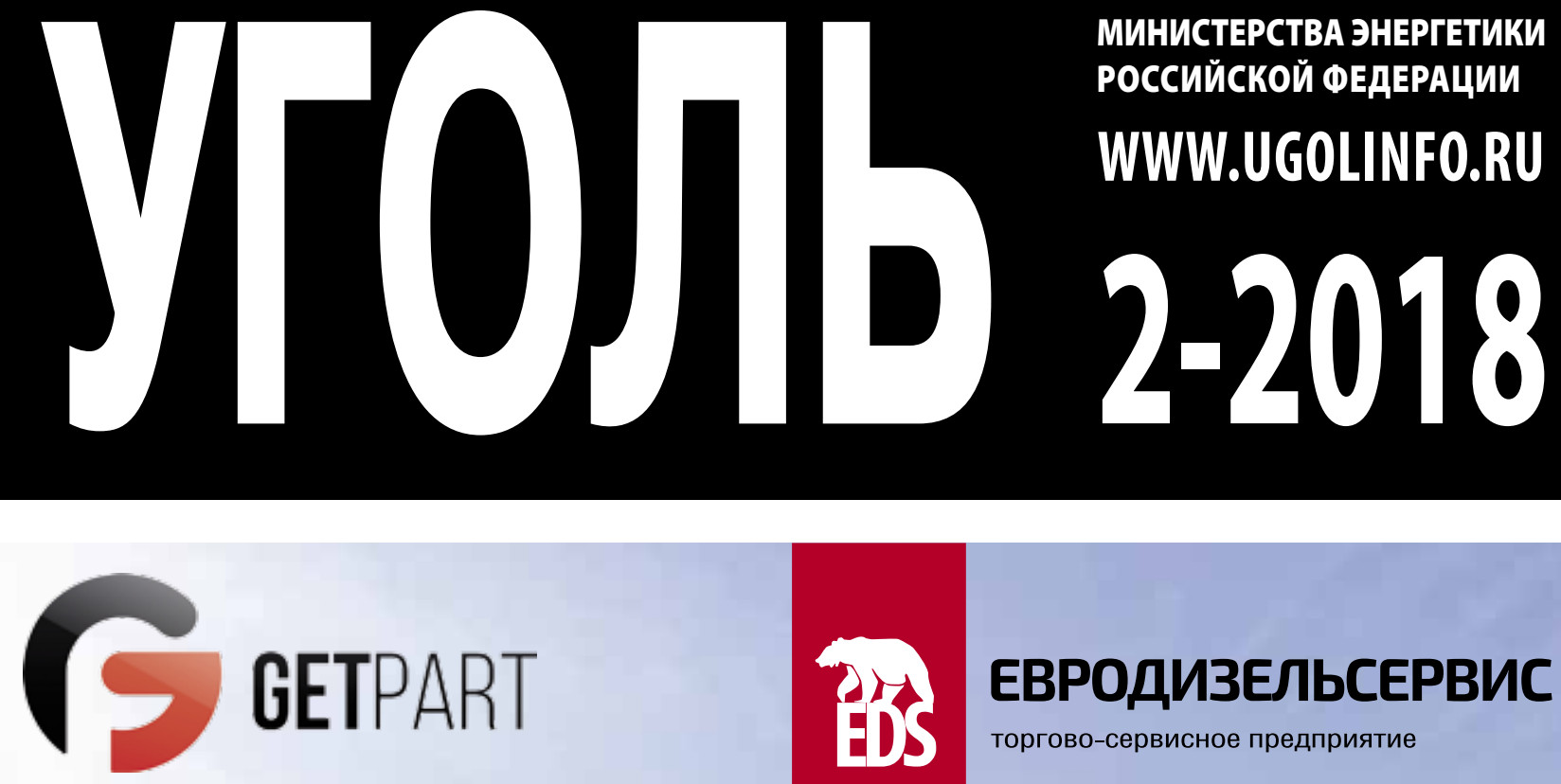

ЕВРОДИЗЕЛЬСЕРВИС

торгово-сервисное предприятие

Технические специалисты компании «ГЕТПАРТ» и сервисного предприятия «ЕВРОДИЗЕЛЬСЕРВИС» разработали полноценный комплекс ИСУА (Интеллектуальная Система Управления Автотранспортом)

Читайте статью на стр. 26 

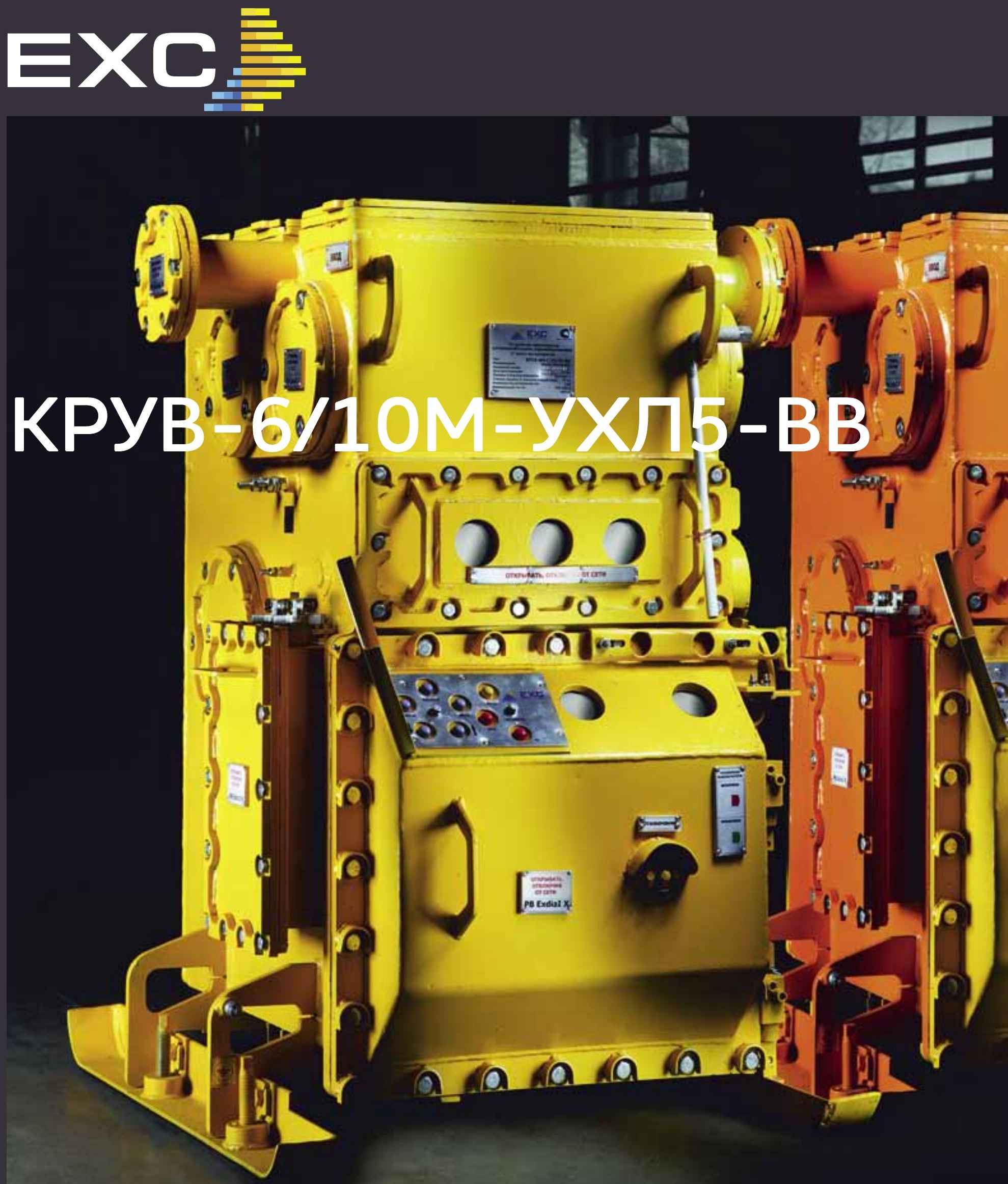

Комплектные распределительные устройства КРУВ-6/10М производятся компанией «EXC» с 2002 года, применяются в шахтах, опасных по пыли и газу, и предназначены для:

-распределения электрической энергии напряжением 6/10 кB;

-защиты отходящих электрических сетей от аварийных процессов;

-управления токоприемниками (в том числе по цифровым интерфейсам);

-выполнения функций автоматики (в том числе в составе распределительных пунктов). 


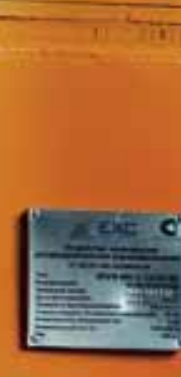

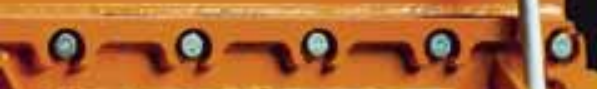

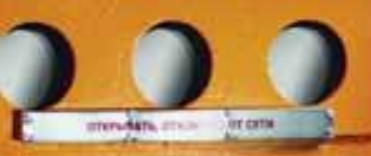

$0-0-0-0,[2$

a

$90 \% 7$

$80 \div$

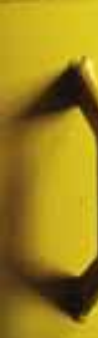
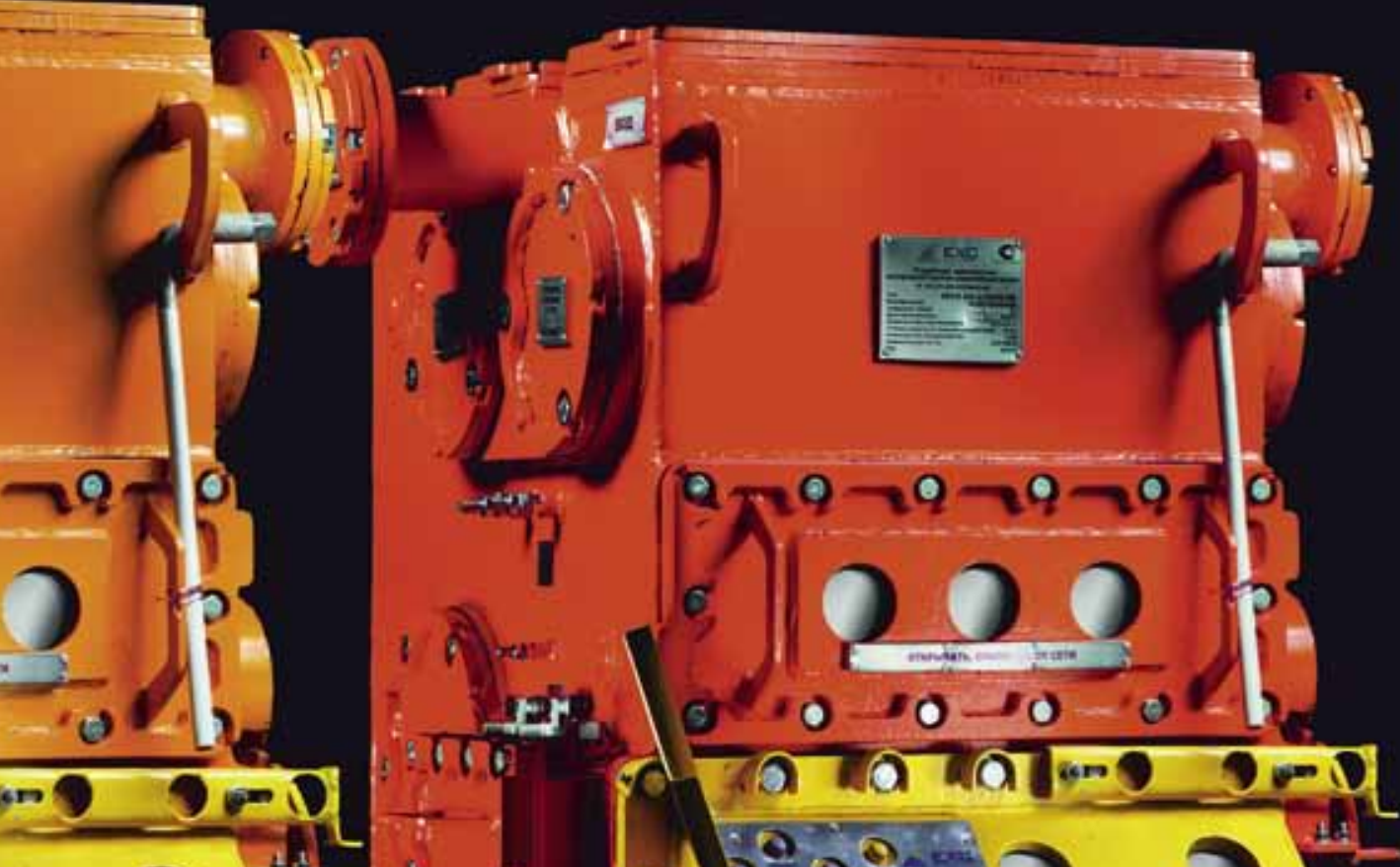


\title{
и стал лидером по итогам производственного соревнования АО «СУЭК» по итогам 2017 года
}

\begin{abstract}
Коллектив экскаваторно-транспортной бригады разрезоуправления «Новошахтинское» $О 00$ «Приморскуголь» достиг рекордного результата работы экскаватора PC-3000 № 9 в объеме 7400000 куб. м. По итогам года экипаж экскватора Komatsu PC-3000 №9 занял первое место в соревновании СУЭК среди экскаваторов с вместимостью ковша 15-19 куб. м.
\end{abstract}

«Безукоризненная трудовая дисциплина, стремление к совершенствованию технологического прочесса, грамотное и ответственное отношение квыполнению взятых на себя обязательств позволили бригаде экскаватора превысить 7-миллионную отметку годового объема по вскрыше и одержать победу в производственном конкурсе среди экскаваторных бригад аналогичного класса в $А О$ «СУЭК», - отметил генеральный директор ООО «Приморскуголь» Александр Заньков.

Высокопроизводительный электрогидравлический экскаватор KOMATSU PC-3000 С вместимостью ковша 16 куб. м введен в эксплуатацию в разрезоуправлении «Новошахтинское» в 2016 г. В 2017 г. - достиг и стабилизировал уровень ежемесячной производительности в объеме более 600 тыс. куб. м.

В 2017 г. коллектив РУ «Новошахтинское» ООО «Приморскуголь» достиг значимых производственных вершин.

В год 35-летия разреза «Павловский № 2» предприятие установило рекорд по отгрузке угля за месяц в объеме 525000 т.

Годовые планы по добыче, вскрыше и отгрузке угля выполнены с опережением календарных сроков.

В сжатые сроки был построен новый разрез «Некковый» на Липовецком каменноугольном месторождении.

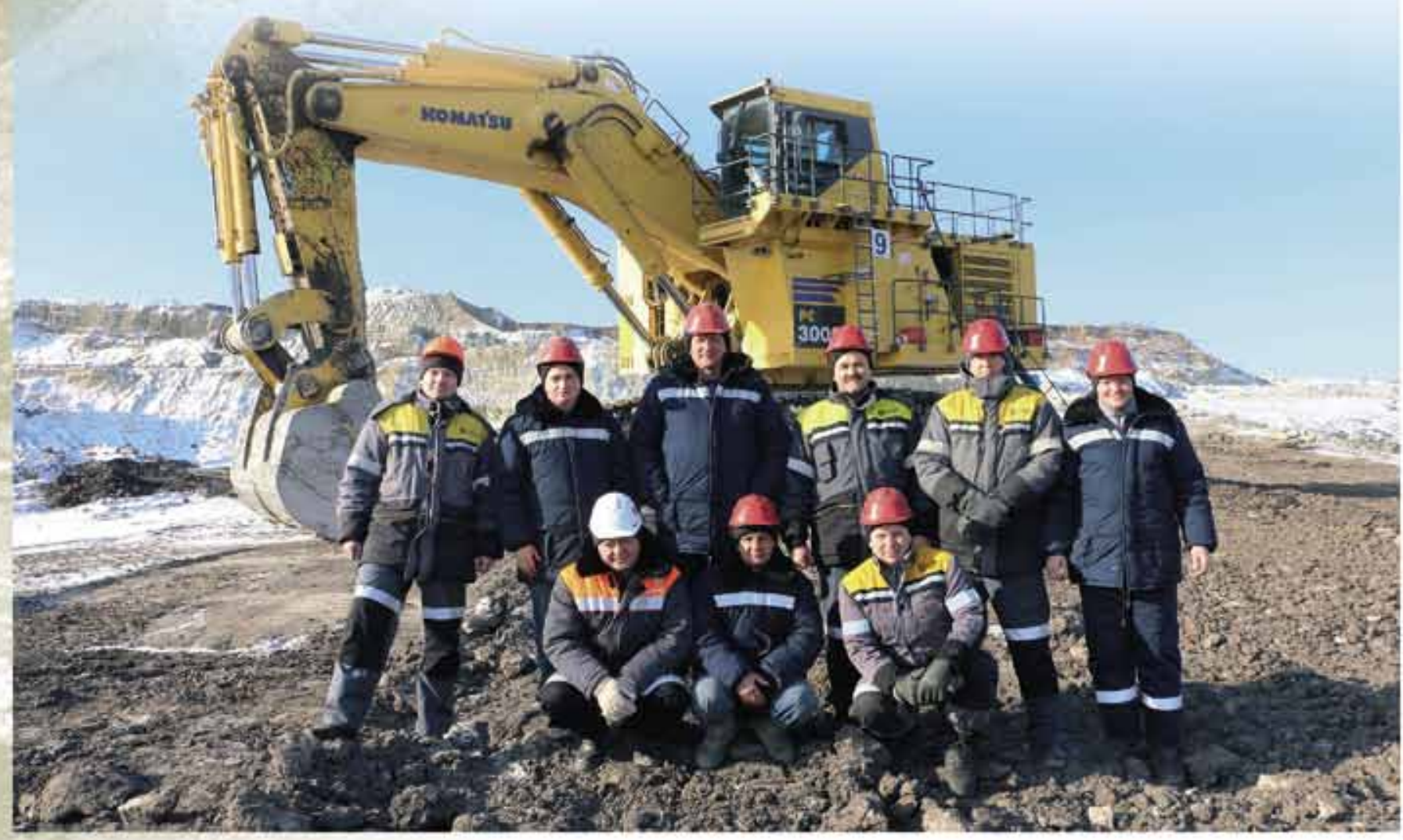


Главный редактор

ЯНОВСКИЙ А.Б.

Заместитель министра энергетики

Российской Федерачии,

доктор экон. наук

\section{Зам. главного редактора}

ТАРАЗАНОВ И.Г.

Генеральный директор

ООО «Редакция журнала «Уголь»,

горный инженер, чл.-корр. РАЭ

\section{РЕДАКЦИОННАЯ КОЛЛЕГИЯ}

АРТЕМЬЕВ В.Б, доктор теХн. наук

ВЕРЖАНСКИЙ А.П.,

доктор техн. наук, профессор

ГАЛКИН В.А., Әоктор техн. наук, профессор

ЗАЙДЕНВАРГ В.Е.,

доктор техн. наук, профессор

ЗАХАРОВ В.Н., ЧЛ.-КОрр. РАН,

Әоктор техн. Наук, профессор

КОВАЛЬЧУК А.Б.,

доктор техн. наук, профессор

ЛИТВИНЕНКО В.С.,

доктор техн. наук, профессор

МАЛЫШЕВ Ю.Н., академИК РАН,

доктор техн. наук, профессор

МОХНАЧУК И.И., КаНд. эКОН. НаУК

МОЧАЛЬНИКОВ С.В., Канд. эКОН. Наук

ПЕТРОВ И.В., доктор эКон. наук, профессор

попов В.Н., доктор экон. наук, профессор

ПОТАПОВ В.П.,

доктор техн. наук, профессор

ПучкОВ л.А., чл.-корр. РАН,

доктор техн. наук, профессор

РОЖков А.А., доктор экон. наук, профессор

РЫБАК Л.В., доктор экон. наук, профессор

СКРЫЛЬ А.И., горный инженер

СУСлОВ В.И., чл.-корр. РАН, доктор экон.

наук, профессор

ЩАДОВ В.М., доктор техн. наук, профессор ЩУКИН В.К., доктор экон. наук

ЯКОВЛЕВ Д.В., доктор техн. наук, профессор

\section{Иностранные члены редколлегии}

Проф. Гюнтер АПЕЛЬ,

доктор техн. наук, Германия

Проф. Карстен ДРЕБЕНШТЕДТ,

доктор техн. наук, Германия

Проф. Юзеф дУБИНьСКИ,

доктор техн. наук, чл.-корр. Польской

академии наук, Польша

Сергей НИКИШИЧЕВ, комп. лицо FIMMM,

канд. экон. наук, Великобритания, Россия,

страны СНГ

Проф. Любен ТОТЕВ,

доктор наук, Болгария

\section{ЕЖЕМЕСЯЧНЫЙ \\ НАУЧНО-ТЕХНИЧЕСКИЙ \\ И ПРОИЗВОДСТВЕННО-ЭКОНОМИЧЕСКИЙ ЖУРНАЛ}

Основан в октябре 1925 года

\section{УЧРЕДИТЕЛИ}

МИНИСТЕРСТВО ЭНЕРГЕТИКИ

РОССИЙСКОЙ ФЕДЕРАЦИИ

РЕДАКЦИЯ ЖУРНАЛА «УГОЛЬ»

ФЕВРАЛЬ

$2-2018 / 1103 /$

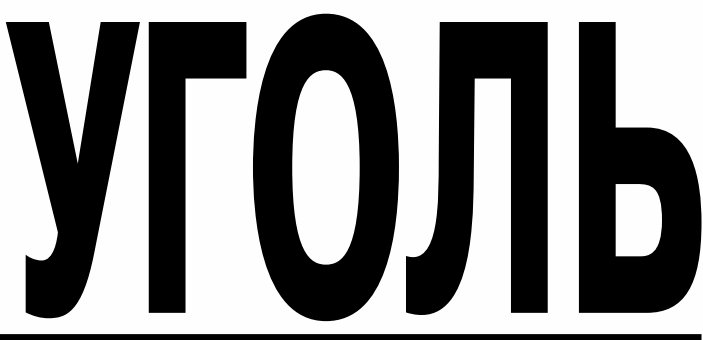

СОДЕРЖАНИЕ

\section{ПРЕСПЕКТИВЫ ТЭК}

Глинина $0 . И$

Итоги III Национального горнопромышленного форума 6

\section{ОТКРЫТЫЕ РАБОТЫ}

Глинина 0.И.

Уралмашзавод и Газпромбанк: комплексные решения для горной промышленности

10

\section{TPAHСПОРТ}

Исайченков А.Б., Довженок А.С., Степанов А.А., Роженко В.В.

Поиск новых возможностей повышения безопасности и эффективности

автотранспортных подразделений АО «СУЭК» 20

Бизнес масел ЛукойЛ: позитивные итоги 24

Шаршавенкова Н.А.

Движение к успеху с помощью инноваций 26

\section{ПОДЗЕМНЫЕ РАБОТЫ}

Попов М.В.

Нагнетание воды в пласт антрацита повышенного давления через скважины направленного бурения благоприятствует экономике и экологии 28

ГОРНЫЕ МАШИНЫ

Габов В.В., Нгуен К.Л., Нгуен В.С., Ле Т.Б., Задков Д.А.

Обоснование геометрических и режимных параметров шнековых исполнительных органов, обеспечивающих эффективность погрузки угля на забойный конвейер 32

\section{РЕСТРУКТУРИЗАЦИЯ}

Моисеенков А.B.

ФГБУ «ГУРШ»- двадцать лет спустя

\section{ЭКОНОМИКА}

Рожков А.А., Соловенко И.С.

Формирование и трансформация институциональной системы регулирования структурных

преобразований в угольной отрасли и на углепромышленных территориях России

Воскобойник М.П., Рожков А.А.

Ретроспективная и прогнозная оценки эффективности технологического развития угольной промышленности России

Бакурова Е.В.

Соглашение о государственно-частном партнерстве как форма реализации проекта переработки углей в синтетическое жидкое топливо на территории Приморского края

ОРГАНИЗАЦИЯ ПРОИЗВОДСТВА

Фомин А.В., Лапаева 0.А., Смолин А.В., Михно М.В.

Особенности культуры труда на японских предприятиях

БЕЗОПАСНОСТЬ

Филатов Ю.М., Игишев В.Г., Шлапаков П.А., Ширяев С.Н., Шлапаков Е.А.

0 новой нормативной базе проблем борьбы с эндогенными пожарами в шахтах 67

\section{ХРОНИКА}

Компания Dassault Systèmes

Цифровизация в России

Хроника. События. Факты. Новости 
ООО «РЕДАКЦИЯ ЖУРНАЛА «УГОЛЬ»

119049, г. Москва,

Ленинский проспект, д. 2А, офис 819

Тел.: +7 (499) 237-22-23

E-mail:ugol1925@mail.ru

E-mail:ugol@land.ru

Генеральный директор

Игорь ТАРАЗАНОВ

Ведущий редактор

Ольга ГЛИНИНА

Научный редактор

Ирина КОЛОБОВА

Менеджер

Ирина ТАРАЗАНОВА

Ведущий специалист

Валентина ВОЛКОВА

ЖУРНАЛ ЗАРЕГИСТРИРОВАН

Федеральной службой по надзору

в сфере связи и массовых коммуникаций.

Свидетельство о регистрации

средства массовой информации

ПИ № ФС77-34734 от 25.12.2008

ЖУРНАЛ ВКЛЮЧЕН

В Перечень ВАК Минобразования и науки РФ

(в международные реферативные базы

данных и системы цитирования) -

по техническим и экономическим наукам

Пятилетний импакт-фактор РИНЦ

без самоцитирования - 0,315

ЖУРНАЛ ПРЕДСТАВЛЕН

в Интернете на вэб-сайте

\section{www.ugolinfo.ru www.ugol.info}

и на отраслевом портале «РОССИЙСКИЙ УГОЛЬ»

\section{www.rosugol.ru}

информационный партнер журнала - УгОЛьНЫЙ ПОРТАЛ

\section{www.coal.dp.ua}

НАД НОМЕРОМ РАБОТАЛИ: Ведущий редактор О.И. ГЛИНИНА

Научный редактор И.М. КОЛОБОВА

Корректор В.В. ЛАСТОВ

Компютерная верстка Н.И. БРАНДЕЛИС

Подписано в печать 05.02.2018.

Формат 60×90 1/8.

Бумага мелованная. Печать офсетная.

Усл. печ. л. 13,0 + обложка.

Тираж 5100 экз.

Тиражэл. версии 1600 экз.

Общий тираж 6700 экз.

Отпечатано:

ООО «РОЛИКС

117218, г. Москва, ул. Кржижановского, 31

Тел.: (495) 661-46-22;

www.roliksprint.ru

Заказ № 45924

Журнал в App Store $и$ Google Play

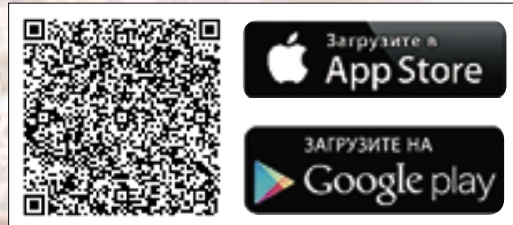

๑ ЖУРНАЛ «УГОЛЬ», 2018
ПЕРЕРАБОТКА УГЛЯ

Ефимов В.И., Корчагина Т.В., Антонов А.И.

К вопросу переработки угольных шламов

ГЕОЛОГИЯ

Гриб Н.Н., Кузнецов П.Ю.

Кластерная организация месторождения как основа планирования

оптимальной плотности сети углеразведочных скважин

81

эКология

Быкадоров А.И., Чернуха А.В., Свирко С.В.

Аспекты ликвидации шахт Прокопьевско-Киселевского угольного месторождения

88

Зеньков И.В., Барадулин И.М.

0боснование горнотехнической рекультивации карьеров

по добыче нерудных материалов для производства щебня

Харионовский А.А., Франк Е.Я.

Обоснование горнотехнической рекультивации по созданию

культурного ландшафта в карьере по разработке глиежей

100

ЮБИЛЕИ

Гизатулин Рифат Хабибулович (к 95-летию со дня рождения) 102

НЕКРОЛОГИ

Кузнецов Виктор Иванович (04.08.1938- 30.12.2017) 104

Сухов Виталий Никитович (29.08.1934- 23.12.2017) 104

Список реклам:

\begin{tabular}{|c|c|c|c|}
\hline GЕTРАRТ ЕВРОДИЗЕЛЬСЕРВИС & 1-я обл. & МУФТА ПРО & 25 \\
\hline EXC & 2-я обл. & НПП Завод Мду & 71 \\
\hline СУЭК & 3-я обл. & & \\
\hline
\end{tabular}

\section{Журнал «Уголь» входит \\ в международные ресеративные базы данных и систем цитирования \\ SCOPUS, GeoRef, Chemical Abstracts}

Журнал «Уголь» является партнером CROSSREF

Редакция журнала «Уголь» является членом Международной ассоциации по связям издателей / Publishers International Linking Association, Inc. (PILA).

Всем научным статьям журнала присваиваются Digital Object Identifier (DOI).

\section{Журнал «Уголь» является партнером EBSCO}

Редакция журнала «Уголь» имеет соглашение с компанией EBSCO Publishing, Inc. (США). Все публикации журнала «Уголь» с 2016 г. входят в базуданных компании EBSCO Publishing (www.ebsco.com), предоставляющей свою базу данных для академических библиотек по всему миру. EBSCO имеет партнерские отношения с библиотеками на протяжении уже более 70 лет, обеспечивая содержание исследований качества, мощные технологии поиска и интуитивные платформы доставки.

\section{Журнал «Уголь» представлен в «КиберЛенинке»}

Электронная научная библиотека «КиберЛенинка» (CYBERLENINKA) входит в mon-10 мировых электронных хранилищ научных публикачий и построена на парадигме открытой науки (Open Science), основными задачами которой являются популяризация науки и научной деятельности, общественный контроль качества научных публикаций, развитие междисциплинарных исследований и повышение цитируемости российской науки. Это третья в мире электронная библиотека по степени видимости материалов в Google Scholar.

Подписные индексы:

- Каталог Роспечати «Газеты. Журналы» - 71000, 71736, 73422

- Объединенный каталог «Пресса России» - 87717, 87776, 987717

- Каталог «Почта России» - П3724

- Каталог «Российской прессы» - 11538

- Каталог «Урал-Пресс» - 71000; 007097; 009901 
UGOL' / RUSSIAN COAL JOURNAL UGOL' JOURNAL EDITORIAL BOARD

Chief Editor

YANOVSKY A.B., Dr. (Economic), Ph.D. (Engineering), Deputy Minister of Energy of the Russian Federation, Moscow, 107996, Russian Federation

Deputy Chief Editor

TARAZANOV I.G., Mining Engineer, Moscow,

119049, Russian Federation

Members of the editorial council:

ARTEMIEV V.B., Dr. (Engineering),

Moscow, 115054, Russian Federation

VERZHANSKY A.P., Dr. (Engineering), Prof.,

Moscow, 125009, Russian Federation

GALKIN V.A., Dr. (Engineering), Prof.,

Chelyabinsk, 454048, Russian Federation

ZAIDENVARG V.E., Dr. (Engineering), Prof.,

Moscow, 119019, Russian Federation

ZAKHAROV V.N., Dr. (Engineering), Prof.,

Corresp. Member of the RAS,

Moscow, 111020, Russian Federation

KOVALCHUK A.B., Dr. (Engineering), Prof.,

Moscow, 119019, Russian Federation

LITVINENKO V.S., Dr. (Engineering), Prof.,

Saint Petersburg, 199106, Russian Federation

MALYSHEV Yu.N., Dr. (Engineering), Prof.,

Acad. of the RAS, Moscow, 125009, Russian

Federation

MOKHNACHUK I.I., Ph.D. (Economic),

Moscow, 109004, Russian Federation

MOCHALNIKOV S.V., Ph.D. (Economic),

Moscow, 107996, Russian Federation

PETROV I.V., Dr. (Economic), Prof.,

Moscow, 119071, Russian Federation

POPOV V.N., Dr. (Economic), Prof.,

Moscow, 119071, Russian Federation

POTAPOV V.P., Dr. (Engineering), Prof.,

Kemerovo, 650025, Russian Federation

PUCHKOV L.A., Dr. (Engineering), Prof.,

Corresp. Member of the RAS, Moscow, 119049,

Russian Federation

ROZHKOV A.A., Dr. (Economic), Prof.,

Moscow, 119071, Russian Federation

RYBAK L.V., Dr. (Economic), Prof.,

Moscow, 119034, Russian Federation

SKRYL' A.I., Mining Engineer,

Moscow, 119049, Russian Federation

SUSLOV V.I., Dr. (Economic), Prof., Corresp.

Member of the RAS, Novosibirsk, 630090, Russian

Federation

SHCHADOV V.M., Dr. (Engineering), Prof.,

Moscow, 119034, Russian Federation

SHCHUKIN V.K., Dr. (Economic),

Ekibastuz, 141209, Republic of Kazakhstan

YAKOVLEV D.V., Dr. (Engineering), Prof.,

Saint Petersburg, 199106, Russian Federation

Foreign members of the editorial council:

Prof. Guenther APEL, Dr.-Ing.,

Essen, 45307, Germany

Prof. Carsten DREBENSTEDT, Dr. (Engineering),

Freiberg, 09596, Germany

Prof. Jozef DUBINSKI, Dr. (Engineering), Corresp.

Member PAS, Katowice, 40-166, Poland

Sergey NIKISHICHEV, FIMMM, Ph.D. (Economic),

Moscow, 125047, Russian Federation

Prof. Luben TOTEV, Dr., Sofia, 1700, Bulgaria

Ugol' Journal Edition LLC

Leninsky Prospekt, 2A, office 819

Moscow, 119049, Russian Federation

Tel.: +7 (499) 237-2223

E-mail: ugol1925@mail.ru

www.ugolinfo.ru
MONTHLY JOURNAL, THAT DEALS WITH SCIENTIFIC, TECHNICAL, INDUSTRIAL AND ECONOMIC TOPICS

Established in October 1925

FOUNDERS

MINISTRY OF ENERGY

THE RUSSIAN FEDERATION,

UGOL' JOURNAL EDITION LLC

FEBRUARY

$2^{\prime} 2018$

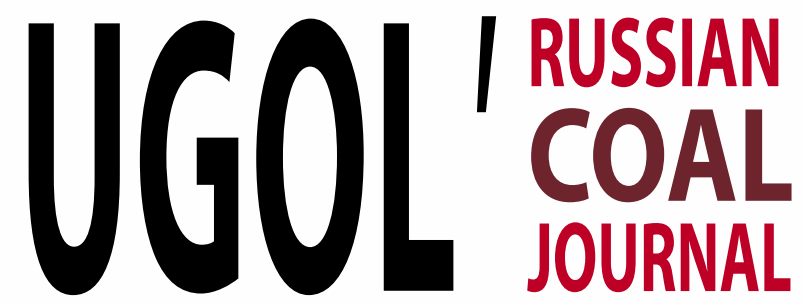

\section{FUEL AND ENERGY COMPLEX OUTLOOK}

CONTENT

Glinina 0.1 .

III National Mining Forum results

SURFACE MINING

Glinina 0.I.

Uralmashplant and Gazprombank: integrated solutions for mining industry 10

TRANSPORT

Isaychenkov A.B., Dovzhenok A.S., Stepanov A.A., Rozhenko V.V.

SUEK, JSC transportation companies in search for new safety and efficiency opportunities

Sharshavenkova N.A.

Reaching success through innovations

UNDERGROUND MINING

Popor M.V.

Water injection in high pressure anthracite stratum through directional drilling boreholes

is beneficial for economics and environment

COAL MINING EQUIPMENT

Gabov V.V., Nguyen K.L., Nguyen V.X., Le T.B., Zadkov D.A.

The rationale of geometric and modal parameters of cutter drums ensuring

the efficiency of coal loading onto a downhole conveyor

RESTRUCTURING

Moiseenkov A.V.

"GURSH" FSBI - twenty years later

ECONOMIC OF MINING

Rozhkov A.A., Solovenko I.S.

Formation and transformation of the institutional system for the Russian coal industry

and coal provinces structural transformations management

Voskoboinik M.P., Rozhkov A.A.

Russian coal industry technological development efficiency historical and predictive analysis

Bakurova E.V.

Agreement on public-private partnership as a form of realization of the project

of processing coal into synthetic liquid fuels on the territory of Primorsky Krai

PRODUCTION SETUP

Fomin A.V., Lapaeva O.A., Smolin A.V., Mikhno M.V.

Specific features of the Japanese enterprises work culture

SAFETY

Filatov Yu.M., Igishev V.G., Shlapakov P.A., Shiryaev S.N., Shlapakov E.A.

New regulatory framework for endogenous fires problems in coal mines

CHRONICLE

The chronicle. Events. The facts. News

COAL PREPARATION

Efimov V.I., Korchagina T.V., Antonov A.I.

On coal slurry processing

GEOLOGY

Grib N.N., Kuznetsov P.Yu.

Cluster-based arrangement of the deposit as a basis of the planning reasonable density of coal wells 81

ECOLOGY

Bykadorov A.I., Chernukha A.V., Svirko S.V.

Aspects of liquidation of mines of the Prokopyevsko-Kiselevsky coal deposit

Zenkov I.V., Baradulin I.M.

Substantiation of mining-engineering reclamation of nonmetallic materials quarries for ballast production

96

Kharionovsky A.A., Frank E.Ya.

Substantiation of mining-engineering reclamation for burnt clay mines cultivated landscaping

ANNIVERSARIES

Gizatulin Rifat Habibulovich (to a 95-anniversary from birthday) 102

NECROLOGUE

Kuznetsov Victor Ivanovich (04.08.1938 - 30.12.2017)

104

Sukhov Vitaly Nikitovich $(29.08 .1934-23.12 .2017)$ 


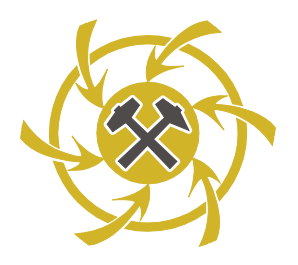

\section{Итоги III Национального горнопромышленного форума}

DOI: http://dx.doi.org/10.18796/0041-5790-2018-2-6-9

\author{
ГЛИНИНА Ольга Ивановна \\ Горный инженер, ведущий редактор \\ ООО «Редакция журнала «Уголь», \\ 119049, г. Москва, Россия, \\ e-mail:ugol1925@mail.ru
}

В ноябре 2017 г. в г. Москве состоялся III Национальный горнопромышленный форум. Руководители ведущих российских горнопромышленных предприятий обсудили стратегии инновационного развития отрасли, представили новейшие технологии, рассказали о проектах восстановления экологии на территориях, где велись разработки месторождений. Участники форума привлекли внимание к проблемам минерально-сырьевого комплекса страны и решению задач, поставленных государством, что подтверждается участием в форуме руководителей профильных федеральных министерств, представителей крупных компаний российского минеральносырьевого комплекса и горного бизнеса зарубежных стран.

Ключевые слова: минерально-сырьевые ресурсы, горная промышленность, топливноэнергетический комплекс, недропользование, стратегическое планирование, техническое регулирование, инновачионное развитие, подготовка кадров, экология.

\section{ВВЕДЕНИЕ}

В рамках III Национального горнопромышленного форума прошло обсуждение актуальных вопросов функционирования и развития минерально-сырьевого сектора экономики России по темам:

- повышение конкурентоспособности и перспективы развития минерально-сырьевого комплекса России;

- четвертая технологическая революция: стратегии и перспективы промышленного партнерства в минерально-сырьевой сфере.

В адрес участников Форума поступили приветствия: от председателя Совета Федерации Федерального Собрания Российской Федерации В.И. Матвиенко и заместителя председателя Правительства Российской Федерации А.Г. Хлопонина.

Форум открыли: председатель Высшего горного совета Ю.К. Шафраник виче-президент Торгово-промышленной палаты Российской Федерачии Д.Н. Курочкин депутат Государственной Думы России, Почетный председатель Высшего горного совета С.М. Миронов.

С докладами по основным вопросам обсуждаемых тем выступили: президент НП «Горнопромышленники России» В.А. Язев; директор государственного геологического музея им. В.И. Вернадского РАН, президент Академии горных наук, академик РАН Ю.Н. Малышев; заместитель министра энергетики Российской Федерации А.Б. Яновский; первый вице-президент, операционный директор ПАО «ГМК «Норильский никель» С.Н. Дяченко; Советник председателя Союза старателей России П.Д. Луняшин; вице-президент Российского геологического общества Л.В. Оганесян; директор Института проблем комплексного изучения недр РАН, чл.-кор. РАН В.Н. Захаров; президент ОЮЛ «Горнопромышленный союз Казахстана», президент Национальной академии горных наук Казахстана,

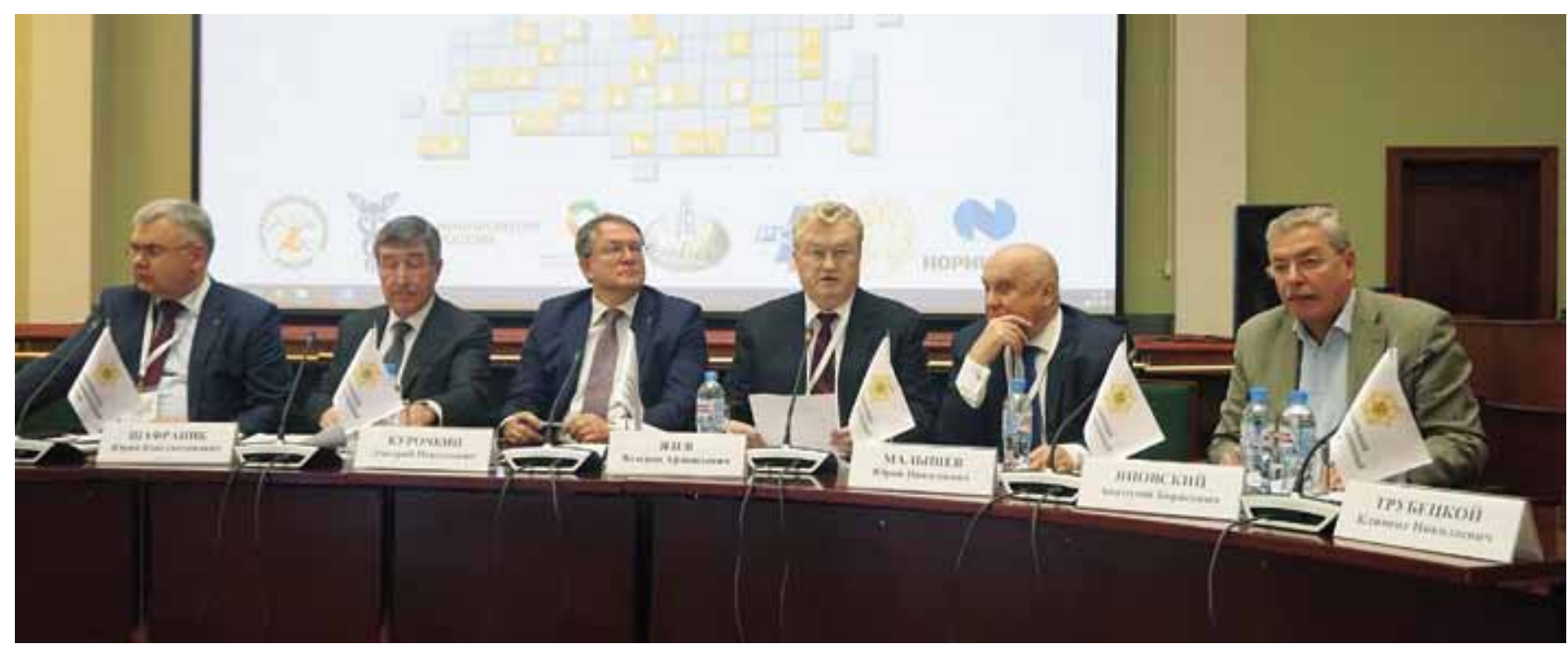


Почетный член Национальной академии наук Казахстана Н.Б. Рыспанов; заместитель председателя Комитета Совета Федерации России по экономической политике С.В. Шатиров; заместитель министра промышленности и торговли Российской Федерации В.С. Осьмаков; научный руководитель Горного института Кольского научного центра РАН, академик РАН Н.Н. Мельников; начальник отдела стратегического развития АО «Концерн «Морское подводное оружие - Гидроприбор» В.Н. Пылаев; заместитель генерального директора $\mathrm{AO}$ «НПО «РИВС» Ю.А. Чертков; директор Института горного дела Уральского отделения РАН, президент НП «Горнопромышленная Ассоциация Урала» С.В. Корнилков; генеральный директор АО «ПромТяжМаш» Р.В. Лабурцев; генеральный директор Института комплексного использования минерального сырья и отходов при РАЕН (ИКИМСО) В.Н. Лыгач; генеральный директор АО «СОМЭКС» А.Ю. Никитин.

\section{МИНЕРАЛЬНО-СЫРЬЕВОЙ КОМПЛЕКС ПО-ПРЕЖНЕМУ ОСТАЕТСЯ ФУНДАМЕНТОМ \\ РОССИЙСКОЙ ЭКОНОМИКИ}

Участниками Форума было отмечено, что сегодня минерально-сырьевые ресурсы обеспечивают в стоимостном выражении более $80 \%$ экспорта страны. Рост объемов производства и экспорта предприятий горной промышленности фактически обеспечивает основную долю роста российской экономики $[1,2,3]$.

За 2017 г. значение горной промышленности для экономики страны и благосостояния населения возросло. Произошло это в первую очередь благодаря существенному росту цен на основные виды продукции: нефть, уголь, алюминий, медь, никель и другие минералы. Доходы от экспорта в значительной степени компенсировали негативное влияние рецессии российской экономики в 2014-2016 гг.

Вместе с тем перспективы развития горнопромышленного комплекса в ближайшие годы вызывают глубокую озабоченность с точки зрения как ситуации на мировом рынке сырья, так и состояния внутреннего рынка и обеспечения наших предприятий необходимым оборудованием. Подавляющее большинство экспертов считают, что мировая экономика вступила в очередной длительный период относительно низких цен на сырьевые товары. По всем прогнозам, ожидать возвращения к прежним уровням цен на основные экспортные товары нереально, также невероятен и сколько-нибудь серьезный рост спроса, за исключением, может быть, меди и никеля в связи с ростом производства электромобилей.

Стагнация спроса автоматически влечет за собой дальнейшее обострение ценовой конкуренции. Внутренний спрос практически на всю номенклатуру рос- сийской продукции также сокращается. Из-за международных санкций серьезно затруднено обновление оборудования. По заключениям специалистов, по отдельным видам оборудования доля импорта доходит до 80 - 100\%. Особую тревогу вызывает обеспеченность российским оборудованием подземных горных работ и обогатительных фабрик.

За последние два года ухудшилась ситуация и на внутреннем рынке. С одной стороны, сократился спрос на минерально-сырьевые ресурсы, а с другой - продолжается рост тарифов на электроэнергию, газ, транспорт. В качестве самого актуального примера можно привести последние предложения Минэнерго России по изменению перекрестного субсидирования цен на электроэнергию, грозящие существенным ростом цен для промышленных предприятий.

Наиболее острыми проблемами в минеральносырьевых отраслях являются:

- за прошедшие два года не произошло никаких позитивных изменений в системе налогообложения горнопромышленного комплекса. Она по-прежнему не способствует вложениям в геологоразведочные работы и воспроизводству минерально-сырьевой базы. Нет стимулов для роста малых и средних предприятий;

- размеры стартовых платежей для получения лицензий не соответствуют нынешнему уровню цен на отечественную продукцию;

- своевременному перемещению отрасли на восток препятствует отсутствие инфраструктуры, строительство которой невозможно без помощи государства;

- для разработки малых месторождений необходимо возродить «правило двух ключей»;

- по-прежнему слишком высокой для развития отрасли является ставка кредитования. При такой ставке практически невозможен рост малых и средних предприятий, являющихся драйверами прогресса в отрасли;

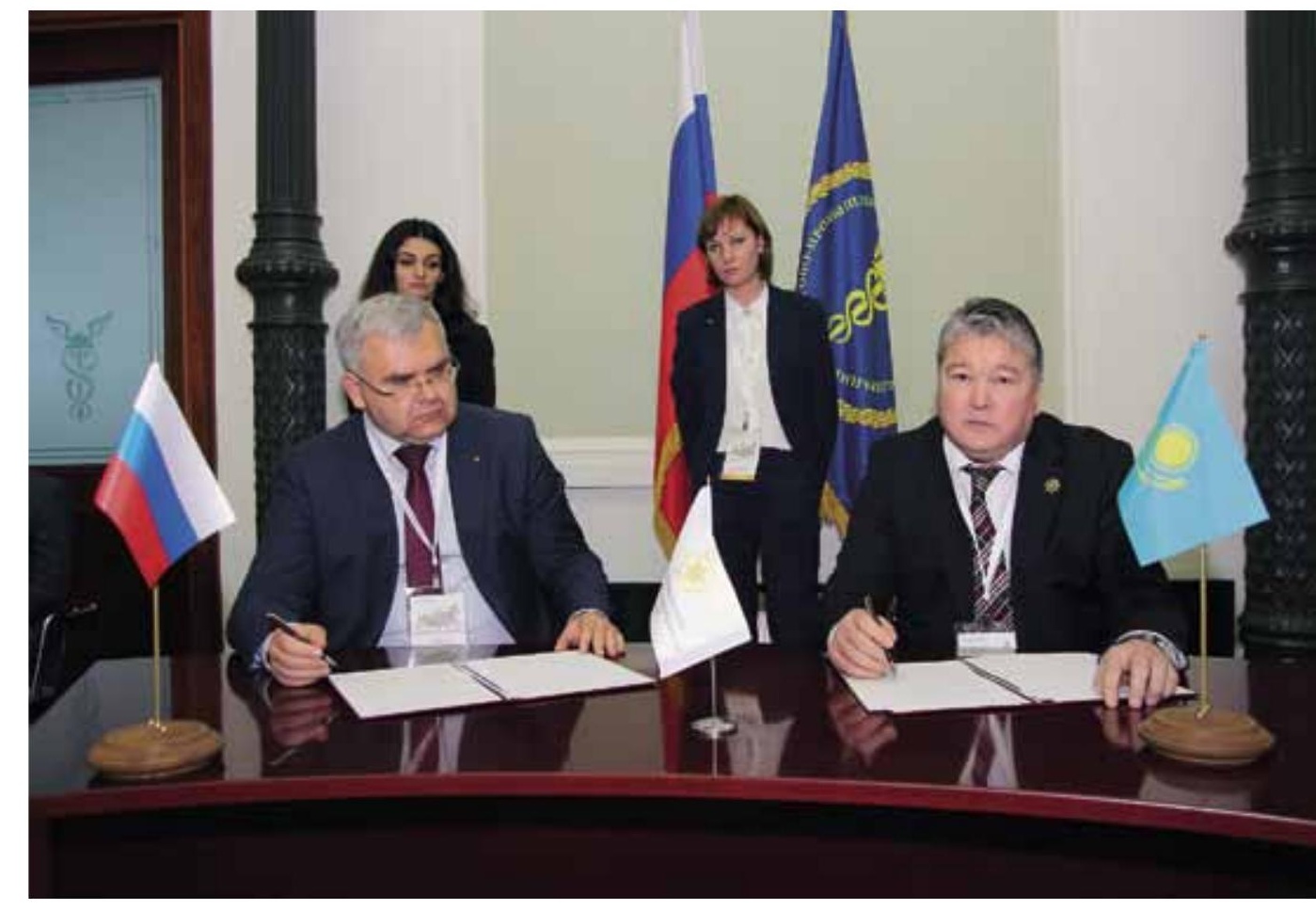


- в последнее время участились жалобы предпринимателей на пристрастность судебной системы и недостаточную защищенность прав собственности.

В долгосрочных прогнозах доля горной промышленности в ВВП России останется значительной до 2030 г.

\section{СТРАТЕГИЯ РАЗВИТИЯ}

\section{МИНЕРАЛЬНО-СЫРЬЕВОЙ БАЗЫ}

\section{РОССИЙСКОЙ ФЕДЕРАЦИИ ДО 2030 Г.}

В настоящее время идет разработка Стратегии развития минерально-сырьевой базы Российской Федерации до 2030 г. Успех ее реализации может обеспечить только полный учет интересов отраслей горнопромышленного комплекса.

Особую важность для высокорисковых и капиталоемких минерально-сырьевых отраслей представляют такие факторы, как стабильное государственное регулирование, разумные условия кредитования и благоприятный инвестиционный климат - прежде всего с точки зрения защиты прав собственности.

Собственные, внутренние инвестиции в горнорудную и нефтегазовую отрасли поддерживаются устойчивым притоком выручки от экспорта и внутреннего потребления минерально-сырьевых ресурсов. Это основной источник инвестиций в отрасль. Но структура инвестиций не позволяет за счет амортизационных отчислений «омолаживать» основные средства горнодобывающих предприятий. Большая доля - в структуре у заемных средств, доступ к которым ухудшается. Износ основных фондов высокий - в среднем 60 - 80\%. Тем не менее средний возраст машин и оборудования в секторе добычи полезных ископаемых с 2012 г. неуклонно снижается (с 8,3 лет в 2012 г. до 7,2 лет в 2016 г.). И предприятиям, и государству необходимо совершенствовать амортизационные механизмы, чтобы они работали на восстановление основных фондов.

Рост прямых внешних инвестиций в горнодобывающий и горно-обогатительный бизнес будет сдерживаться санк- циями, угрозой новых санкций, ухудшением доступа к финансированию новых проектов, общей осторожностью инвесторов в связи с неясностью для них внешнеэкономической политики США, политическим кризисом в Европейском Союзе.

Многие эксперты оценивают, что для портфельных инвестиций в горнорудную промышленность из-за ситуации на мировых минерально-сырьевых рынках сегодня не самое лучшее время. Динамика курсов акций российских минерально-сырьевых компаний часто оказывается «в красной зоне».

Затраты на проведение геологоразведочных работ на углеводородное сырье снижаются с 2014 г., но остаются существенно выше затрат 2011 г. Государственное финансирование геологоразведочных работ на твердые полезные ископаемые также снижается. Низкий уровень выполнения показателей программы локализации прогнозных ресурсов по цветным и редкоземельным металлам. Разведка не обеспечивает воспроизводство минерально-сырьевой базы по титану, железным рудам, цирконию, никелю, хрому.

\section{ВАЖНЫЕ ИНИЦИАТИВЫ}

\section{НЕКОММЕРЧЕСКОГО ПАРТНЕРСТВА}

\section{«ГОРНОПРОМЫШЛЕННИКИ РОССИИ»}

Участники III Национального горнопромышленного форума одобрили важные инициативы Некоммерческого партнерства «Горнопромышленники России», в числе которых:

- проведение совместно с Министерством промышленности и торговли Российской Федерации в Москве в апреле 2018 г. международной выставки горной промышленности «ГОРПРОМЭКСПО-2018», посвященной развитию отраслей минерального сырьевого комплекса и продвижению российских экспортеров на международные рынки;

- подготовка и проведение в 2019 г. совместно с Советом Федерации, Государственной Думой, Союзом маркшейдеров России юбилейных мероприятий, посвященных 300-летию российского горного законодательства;

- создание на базе Некоммерческого партнерства «Горнопромышленники России» экспертно-переговорной площадки для открытого обсуждения вопросов производства новых видов оборудования представителями горнодобывающих предприятий, машиностроительных предприятий и предприятий обороннопромышленного комплекса;

- проведение на регулярной основе изучения планов и практики применения горнопромышленными предприятиями информационно-технических справочников по наилучшим доступным технологиям;

- создание постоянной рабочей группы по мониторингу реализации государственных стратегий, государственных программ, планов законопроектной деятельности федеральных и региональных органов государственной власти в области недропользования, подготовке от имени горнопромышленников отзывов и предложений по разрабатываемым, рассматриваемым 
и принятым федеральным законам, а также законам субъектов Российской Федерации;

- вхождение в состав Торгово-промышленной палаты Российской Федерации. Расширение сотрудничества с ТПП РФ путем участия в Совете по промышленному развитию и конкурентоспособности экономики России, Совете по развитию информационных технологий и цифровой экономики и Комитете по промышленной безопасности;

- поддержка проектов дистанционного повышения квалификации горных инженеров, горных мастеров, других инженернотехнических работников горнодобывающих отраслей;

- укрепление связей и развитие партнерства с зарубежными профессиональными ассоциациями и союзами предприятий минерально-сырьевой сферы, в частности, с Горнопромышленным союзом Казахстана и Российско-Германским сырьевым форумом.

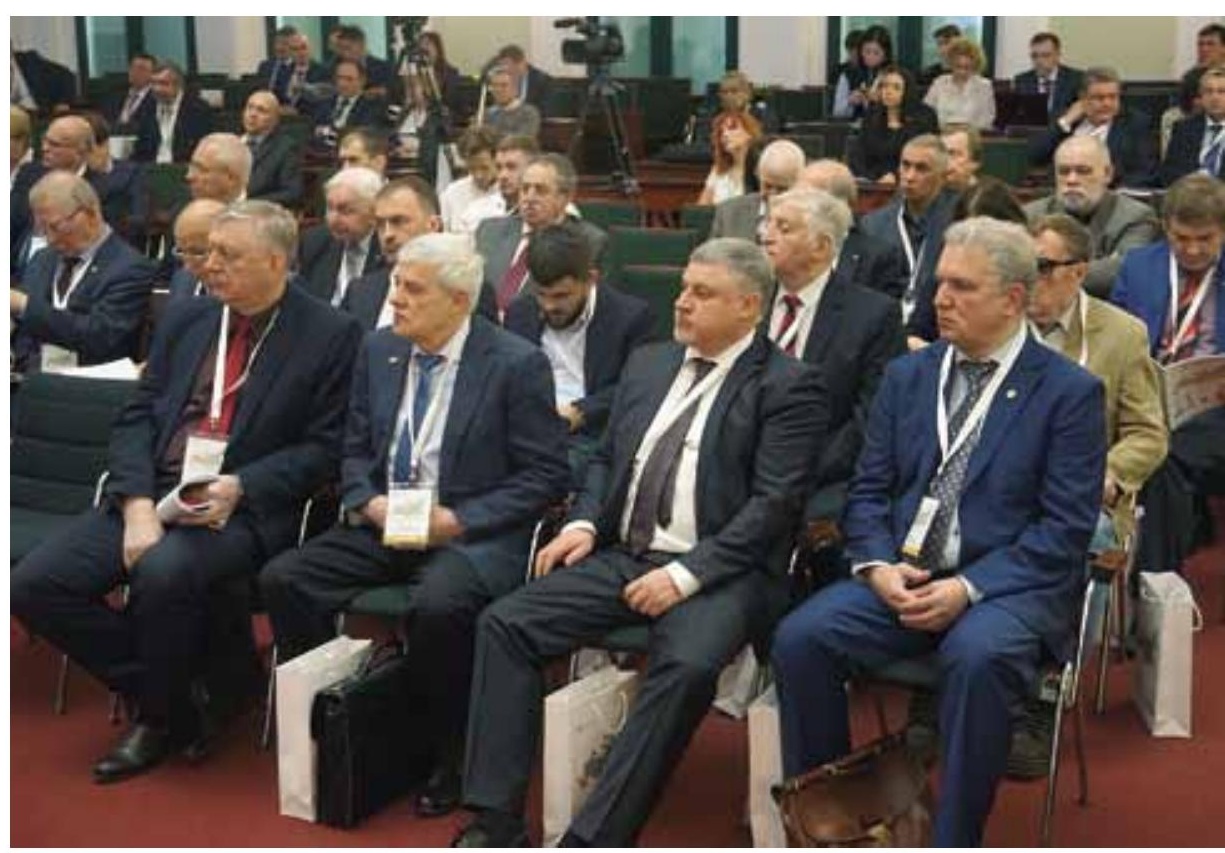

\section{ЗАКЛЮЧЕНИЕ}

Участниками Форума стали около 300 представителей горнопромышленного бизнеса, образования, науки, руководителей федеральных и региональных органов власти. В рамках мероприятия, организованного в здании Торговопромышленной палаты Российской Федерации, были представлены также выставочные экспозиции российских компаний, научно-исследовательских и проектных организаций, работающих в горнопромышленном комплексе.

На Форуме обсуждались ключевые направления развития отечественного горного комплекса, вопросы привлечения инвестиций и совершенствования отраслевого законодательства, стимулирующие механизмы для эффективного использования техногенных месторождений и реализации проектов переработки минерального сырья.

Участники Форума поручили Некоммерческому партнерству «Горнопромышленники России» довести до уполномоченных федеральных органов государственной власти и органов власти субъектов Российской Федерации в соответствии с их компетенцией рекомендации в области стратегического планирования, в области законодательства и технического регулирования, в области инновационного развития, в области подготовки кадров.

\section{Список литературы}

1. Таразанов И.Г. Итоги работы угольной промышленности России за январь-декабрь 2016 года // Уголь. 2017. № 3. C. 36-50. doi: 10.18796/0041-5790-2017-3-36-50. URL: http://www.ugolinfo.ru/Free/032017.pdf (дата обращения: 15.01.2018).

2. Таразанов И.Г. Итоги работы угольной промышленности России за январь-сентябрь 2017 года // Уголь. 2018. № 1. С. 18-32. doi: 10.18796/0041-5790-2018-1-18-32

3. Яновский А.Б. Основные тенденции и перспективы развития угольной промышленности России // Уголь. 2017. № 8. C.10-14. doi: 10.18796/0041-5790-2017-8-10-14. URL: http://www.ugolinfo.ru/Free/082017.pdf (дата обращения: 15.01.2018).

\section{FUEL AND ENERGY COMPLEX OUTLOOK}

UDC 061.3:622.3(470) ๑ O.I. Glinina, 2018

ISSN 0041-5790 (Print) • ISSN 2412-8333 (Online) •

Ugol' - Russian Coal Journal, 2018, № 2, pp. 6-9

\section{Title}

III NATIONAL MINING FORUM RESULTS

DOI: http://dx.doi.org/10.18796/0041-5790-2018-2-6-9

\section{Author}

Glinina O.I. ${ }^{1}$

${ }^{1}$ Ugol' Journal Edition LLC, Moscow, 119049, Russian Federation

\section{Authors' Information}

Glinina O.I., Mining Engineer, Leading Editor of the Russian Coal Journal (Ugol'), e-mail: ugol1925@mail.ru

\section{Abstract}

In November 2017, the III National Mining Forum was held in Moscow. The top tier Russian mining companies'leaders discussed the strategies for the industry innovative development, presented the advanced technologies and environmental remediation projects in the territories where deposits were developed.

The forum participants drew attention to the problems of the country's mineral resources complex and the resolution of the tasks set by the state, which was facilitated by involvement of the relevant federal ministries leaders and representatives of the major Russian mineral resources complex and international mining companies.

\section{Keywords}

Mineral resources, Mining industry, Fuel and energy complex, Subsoil resources management, Strategic planning, Technical regulation, Innovative development, Staff training, Environment.

\section{References}

1. Tarazanov I.G. Russia's coal industry performance for January - December, 2016. Ugol' - Russian Coal Journal, 2017, No. 3, pp. 36-50. doi: 10.18796/0041-5790-2017-3-36-50. Available at: http://www.ugolinfo.ru/ Free/032017.pdf (accessed 15.01.2018).

2. Tarazanov I.G. Russia's coal industry performance for January - September, 2017. Ugol' - Russian Coal Journal, 2018, No. 1, pp. 18-32. doi: 10.18796/0041-5790-2018-1-18-32.

3. Yanovsky A.B. Main trends and prospects of the coal industry development in Russia. Ugol' - Russian Coal Journal, 2017, No. 8, pp. 10-14. doi: 10.18796/0041-5790-2017-8-10-14. Available at: http://www.ugolinfo.ru/ Free/082017.pdf (accessed 15.01.2018). 


\section{(43TM VPAПMAШЗАBOA}

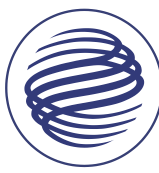

ГАЗПРОМБАНК

\section{Уралмашзавод и Газпромбанк: комплексные решения для горной промышленности}

DOI: http://dx.doi.org/10.18796/0041-5790-2018-2-10-15

\author{
ГЛИНИНА Ольга Ивановна \\ Горный инженер, ведущий редактор \\ ООО «Редакция журнала «Уголь», \\ 119049, г. Москва, Россия, \\ e-mail:ugol1925@mail.ru
}

В статье приводятся основные сведения о III конференции «Уралмашзавод и Газпромбанк: комплексные решения для горной промышленности», которая прошла в г. Екатеренбурге 23-24 ноября 2017 г. На конференцию ежегодно собираются представители крупнейших российских горнодобывающих и горно-металлургических предприятий, а также профильныхинжиниринговых компаний. На пленарном заседании и на двух секциях конференции рассматривался широкий круг вопросов: современная горная техника, импортозамещающие продукты, инновационные технологии и их эффективность. Речь шла об основных тенденциях развития технологий открытых горных работ и рудоподготовки, стратегии развития продуктовой линейки горного оборудования, возможностях комплексных поставок. Отдельно в рамках конференции работали секции экскаваторного и дробильно-размольного оборудования.

Ключевые слова:ПАО «Уралмашзавод», горная промышленность, горная техника, инновационные технологии, открытые горные работы, экскаватор, рудоподготовка, дробильно-размольное оборудование.

\section{ВВЕДЕНИЕ}

ПАО «Уралмашзавод» - один из лидеров российского рынка оборудования для металлургии, горнодобывающей промышленности, промышленности строительных материалов и энергетики. Стратегия развития компании предусматривает создание машиностроительного предприятия мирового уровня, которое сможет комплексно обеспечивать потребности заказчиков в оборудовании. На Уралмашзаводе при поддержке стратегического партнера - AО «Газпромбанк» разработана и реализуется ин- вестиционная программа, предусматривающая коренную реконструкцию производства.

Новая инвестиционная программа рассчитана на 2017 2019 гг. Основной объем средств направлен на модернизацию и приобретение станков для производства ключевой продукции предприятия. Так, в 2018 г. предусмотрены приобретение шести новых станков для механосборочных цехов Уралмашзавода, а также модернизация 18 уже существующих станков механосборочного передела.

Помимо затрат на техническое переоснащение основных производственных цехов часть средств пойдет на реализацию мероприятий по обеспечению промышленной безопасности и подготовку площадки под сборку новых гидравлических экскаваторов.

Благодаря обновлению производственной базы на Уралмашзаводе рассчитывают сократить время на исполнение контрактов, а также повысить качество продукции. Портфель заказов УЗТМ на экскаваторное оборудование сформирован вплоть до середины 2019 г., идет контрактация на последующие годы.

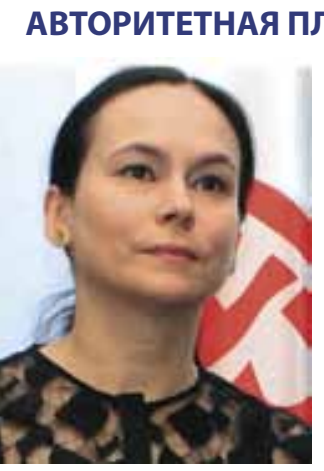

Приветствуягостей и участников конференции, заместитель министра промышленности и науки Свердловской области Виктория Казакова отметила, что данное мероприятие зарекомендовало себя в качестве авторитетной площадки, позволяющей бизнесу, науке и инвестору вести полноценный диалог и вырабатывать комплексные подходы для решения актуальных вопросов развития отрасли.

«В Свердловской области выстроена четкая система государственной промышленной политики -отвыполнения мероприятий в сфере поддержки проектной деятельности до стратегического планирования развития обрабатывающих производств надолгосрочную перспективу. 
По инициативе губернатора региона Евгения Куйвашева принята программа «Пятилетка развития», предусма тривающая развитие промышленности в качестве базиса для обновления реального сектора экономики. Сформированная конструкторская школа УзТМ позволяет решать самые сложные задачи, участие в проектах Газпромбанка дает возможность формировать для потребителя комплексные предложения сучетом всех потребностей заказчика», - сказала Виктория Казакова.

Генеральный директор ПАО «Уралмашзавод» Андрей Кузнецов выразил уверенность, что конференция станет важным этапом сотрудничества с другими компаниями, он также отметил, что за прошедший год на заводе произошло несколько знаковых изменений, в том числе расширение линейки выпуска горного оборудования.

«Уралмашзавод может похвастаться увеличением объема продаж, объемов контрактации, объемов выпуска продукции. В Кузбассе завершается монтаж нашего самого крупного экскаватора ЭКГ-35, уверен, до конца года он будет сдан в опытно-промышленную эксплуатацию. При посещении завода вы увидите в цехах узлы гидравлического экскаватора, который мы изготавливаем для $3 А О$ «Стройсервис». Специально для организации этой сборки и дальнейшего производства мы выделили отдельный цех, провели его реконструкцию, там будем на постоянной основе производить и гидравлические экскаваторы, и шахтоподъемные машины - еще одна наша новая продуктовая линейка», - отметил Андрей Кузнецов.

В рамках конференции между УзтМ и Уральским государственным горным университетом было подписано соглашение о сотрудничестве, направленное на обеспечение качественной подготовки, переподготовки и повышения квалификации сотрудников предприятия и реализацию совместных образовательных, научноисследовательских и опытно-конструкторских программ.

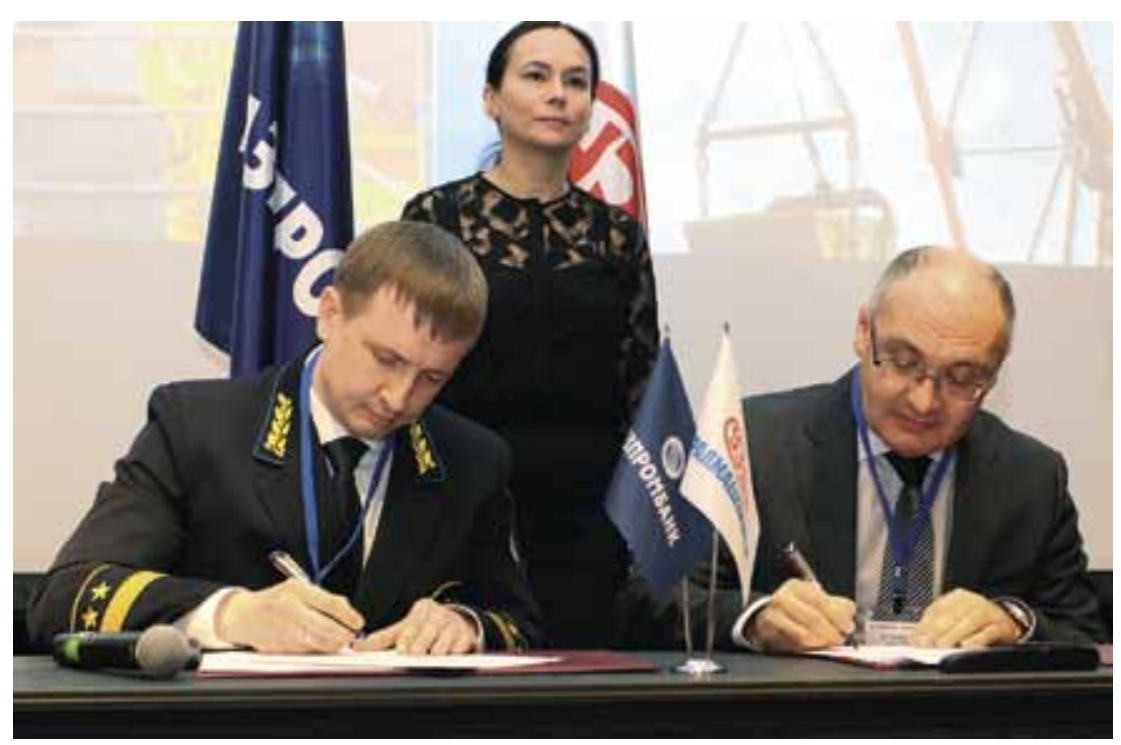

«Горный университет активно развивает взаимодействие с производством. И мы рады, что Уралмашзавод становится все более значимым партнером для нас. Мы готовы выпускать квалифицированных специалистов, востребованных на предприятиях, и заниматься вопросами инжиниринга, проектирования, разработки решений, в том числе в области машиностроения», - отметил и.о. ректора УггУ Алексей Душин.

Подписание соглашения проходило в присутствии заместителя областного министра промышленности и науки Виктории Казаковой. Договор сроком на пять лет призван укрепить существующие связи между вузом и Уралмашзаводом (входит в группу Газпромбанка). Одним из важнейших направлений работы станет подготовка специалистов, востребованных на Уралмашзаводе. Интересы организации будут учитываться при разработке ряда образовательных программ УГГУ. Кроме того, студенты, сориентированные для работы в подразделениях предприятия, примут участие в научно-исследовательской и опытно-конструкторской деятельности по направлениям, предложенным заводом. Потребности работодателя найдут отражение и в выборе тем для курсовых и дипломных работ.

Студенты и магистранты, которые учатся на востребованных на предприятии направлениях подготовки, будут проходить на Уралмашзаводе практики, а наиболее перспективных горных инженеров рекомендуют к трудоустройству начиная с третьего курса. Для работников предприятия на базе УГГУ планируется проведение курсов повышения квалификации и профессиональной переподготовки.

Помимо образовательного, соглашение предполагает и научное сотрудничество. К созданию опытно-конструкторских разработок будут привлечены молодые ученые и опытные научные работники Горного университета.

\section{ВРЕМЯ РЕКОРДОВ}

На пленарном заседании и на двух секциях конференции рассматривался широкий круг вопросов. Речь шла об основных тенденциях развития технологий открытых горных работ [1] и рудоподготовки, о стратегии развития продуктовой линейки горного оборудования, о совершенствовании горного оборудования ПАО «Уралмашзавод", о возможностях комплексных поставок. Обзор и анализ достижений на этом пути, эффективные варианты дальнейших улучшений производства были заслушаны болеечем в 22 докладах участников конференции. И ведь им было о чем рассказать и что показать.

На экскаваторе ЭКГ-20 производства Уралмашзавода в 2017 г. были поставлены два рекорда по объему экскавации [3]. Первый рекорд - 675 тыс. куб. м был достигнут в июле на Калтанском разрезе УК «Кузбассразрезуголь» (входит в УГМК-Холдинг), второй - 604 тыс. куб. м в октябре на разрезе «Березовский» ЗАО «Стройсервис». 


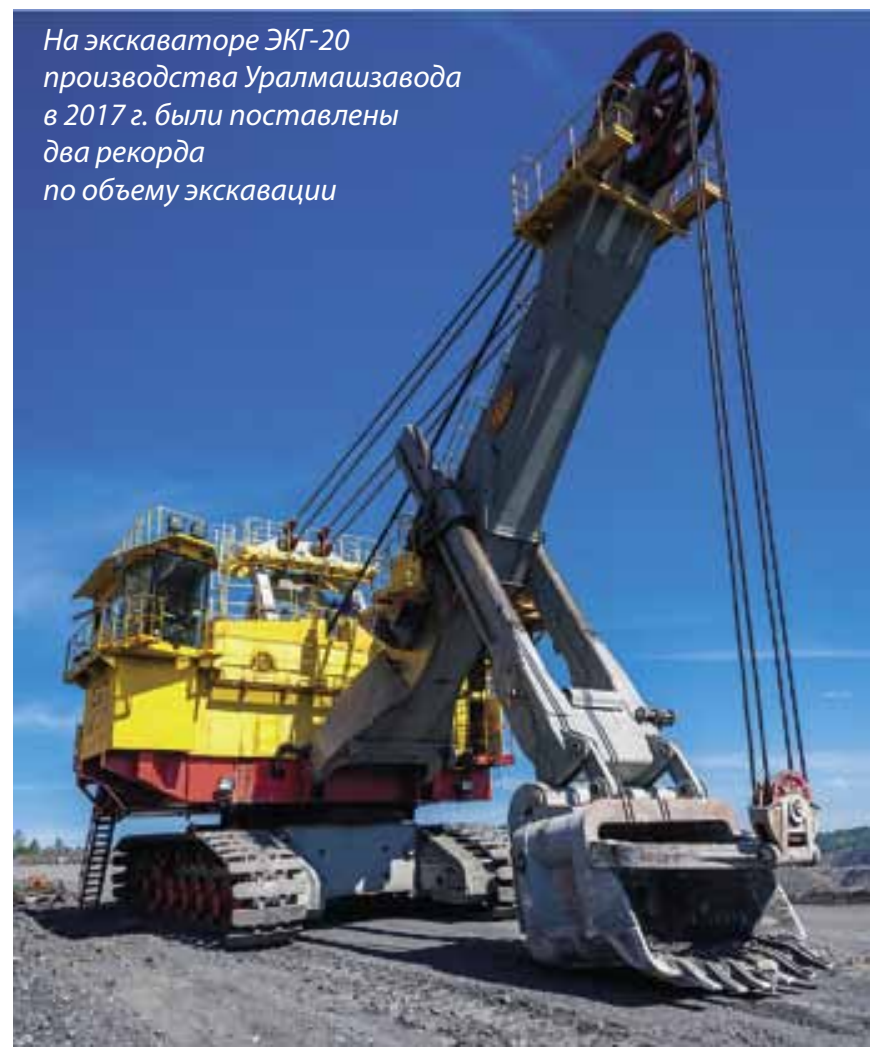

Экскаватор ЭКГ-20 - флагманская машина Уралмашзавода. В настоящее время в эксплуатации находятся 13 машин ЭКГ-20 (ОАО «УК «Кузбассразрезуголь», ПАО «Южный Кузбасс», АО «Полюс», ОАО «УК «КРУ», ООО «Разрез «БерезовСКий», ОАО «ХК «Якутуголь»). В монтаже находятся три машины, а в производстве - 13 машин. И все они расписаны под конкретного заказчика. Практически завод должен отгружать минимум по одной серийной машине ЭКГ-20 в месяц, но объемы производства продолжают увеличиваться, и на IV кв. 2018 г. руководство предприятия ставит задачу выйти на производство двух ЭКГ-20 в месяц. Сварочное и сборочное производства готовятся к переходу на плановую работу в две смены, механообрабатывающие цеха - на круглосуточный график. Если сравнивать основные линейные параметры ЭКГ-20 с моделями-конкурентами, то можно увидеть, что экскаватор УЗТМ превосходит конкурентов по параметру максимальной высоты разгрузки ковша. Это делает его оптимальным для совместного использования с 220-тонными карьерными самосвалами, например марки БелАЗ.

На заводе специально спроектирован под тяжелые железные руды экскаватор ЭКГ-25 с полезным весом в ковше 55 т и вместимостью 25 куб. м. При таких показателях сокращается время погрузки самосвала - увеличивается производительность экскаваторно-автомобильного комплекса. Потенциальные заказчики - железнорудные ГОКи: Ковдорский, Лебединский, Михайловский, Стойленский, Карельский Окатыш, Качканарский ГОК и др.

На Краснобродском разрезе УК «Кузбассразрезуголь» ждут ввода в эксплуатацию нового гиганта Уралмашзавода - карьерного гусеничного экскаватора ЭКГ-35. Это самый крупный из выпускаемых в России карьерных экскаваторов. У машины самый большой радиус копания среди 35-кубовых экскаваторов - меньше переездов, больше экскавации. За счет увеличенных линейных и силовых па- раметров ЭКГ-35 превосходит конкурентов по производительности и технологическим возможностям. При этом у машины самое низкое удельное давление на грунт в своем классе - устойчивая работа на слабонесущих грунтах.

Уже выполнены сборка и монтаж стенок кузова, полным ходом идет установка электрооборудования. Очень скоро под руководством уралмашевских шеф-инженеров начнутся пусконаладочные работы.

Гигант с рабочей массой 1200 т и диапазоном вместимости ковша до 40 куб. м проектировался при непосредственном участии специалистов УК «Кузбассразрезуголь», которые имеют богатый опыт эксплуатации различной экскаваторной техники. Он позволяет максимально эффективно по времени и затратам загружать 220- и 320-тонные самосвалы. В этой машине представлены передовые конструкторские разработки, среди которых привод переменного тока, информационно-диагностическая система и система автоматических защит рабочего оборудования.

И наконец, один из приоритетных для Уралмашзавода проектов - изготовление гидравлического экскаватора УГЭ-300 № 1 для ЗАО «Стройсервис».Уралмашзавод - единственное предприятие в России, которое производит гидравлические экскаваторы. Доля российских комплектующих - более 70\% [4]. На сегодняшний день практически все крупные узлы УГЭ-300 - нижняя рама, поворотная платформа, гусеничные рамы - находятся на сборочной площадке. Над изготовлением новой машины станочники трудятся круглосуточно (табл. 1). В 2018 г. пройдет монтаж рабочего оборудования, систем управления, смазки и пожаротушения. После пусконаладки и испытаний машина будет отгружена заказчику.

В то же время на Уралмашзаводе ведется работа над проектом гидравлического экскаватора УГЭ-300 № 2, обратная лопата с вместимостью ковша 16 куб. м (заказчик ОАО «УК «Кузбассразрезуголь») и УГЭ-120, обратная лопата с вместимостью ковша 7 куб. м.

Доля тяжелых гидравлических экскаваторов с ковшами вместимостью более четырех куб. м составляет порядка 60-70\% всего мирового парка экскаваторного оборудования [5]. Их неоспоримые преимущества - большая мобильность и независимость от электрических сетей, высокаяпроизводительность.ЗадачаУралмашзавода -выйти на рынок гидравлических экскаваторов, предложив российским горнякам машины с техническими решениями, максимально адаптированными к нашим условиям.

На Уралмашзаводе продолжается расширение линейки шагающих экскаваторов. Машины этого типа с маркой УЗТМ хорошо зарекомендовали себя на вскрышных работах с укладкой породы на большие расстояния в выработанное пространство или за борт карьера. Простота монтажа, технического обслуживания и ремонта, надежность,

Таблича 1

Гидравлический экскаватор УГЭ-300, прямая лопата

\begin{tabular}{l|c|} 
Рабочая масса, т & 300 \\
\hline Мощность двигателя, кВт/л.с. & $1119 / 1500$ \\
\hline Температурный диапазон эксплуатации, ${ }^{\circ} \mathrm{C}$ & от -40 до +40 \\
\hline Вместимость ковша, куб. м & 16 \\
\hline $\begin{array}{l}\text { Максимальное усилие копания ковшом, кH, } \\
\text { не менее }\end{array}$ & 1200 \\
\end{tabular}




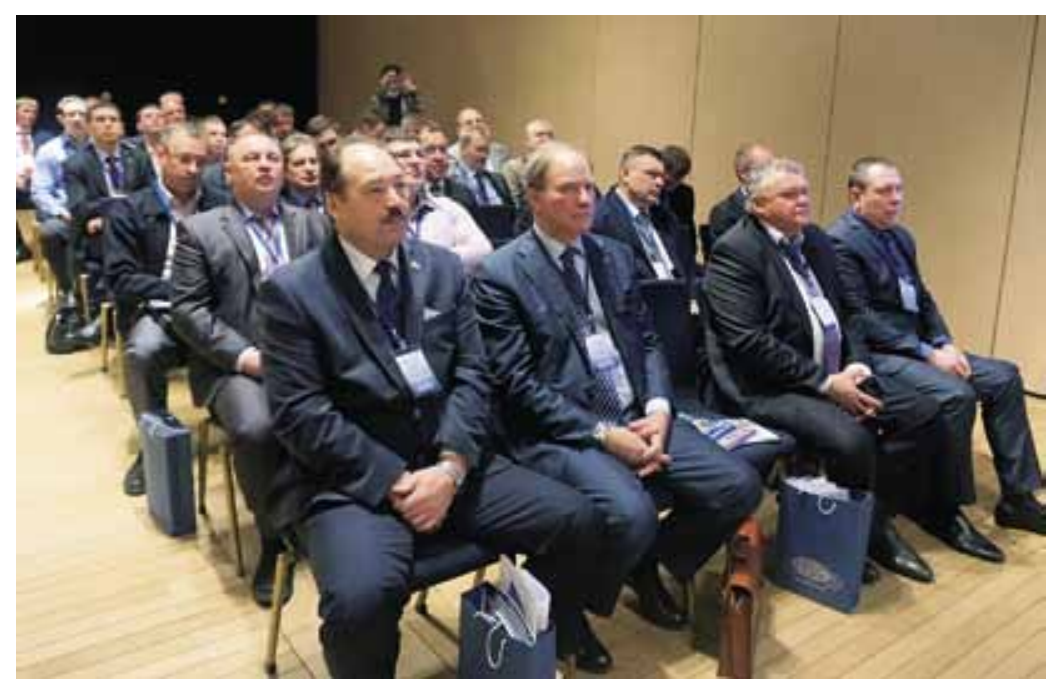

станет большим шагом в области импортозамещения.

Цена шахтной подъемной машины Уралмашзавода вполне конкурентна, при этом она максимально экономична с точки зрения расхода электроэнергии, что в итоге позволит уменьшить себестоимость производства конечной продукции.

Большое внимание было уделено безопасности работы. Для этого в конструкции машины будут применены гидравлические дисковые тормоза, которые также улучшат технологическое управление добычей.

Предусмотрен высокий уровень автоматизации: машина будет оснащена современной системой управления, разработанной отечественными программистами, с визуализацией

повышенная готовность механизмов к работе, высокая маневренность, хорошая проходимость, широкие технологические возможности позволяют эксплуатировать драглайны с большой эффективностью. Экскаваторы надежно работают при температуре от -50 до $+40^{\circ} \mathrm{C}$. Уралмашзавод предлагает заказчикам 13 типоразмеров драглайнов с ковшами вместимостью 11 - 40 куб. м и длиной стрелы 75 - 100 м, в том числе варианты с пониженным удельным давлением на грунт.

Выпущен драглайн ЭШ-11.75 на переменном токе. Если сравнивать машину с ближайшим конкурентом ЭШ-10.70, то видим увеличенные линейные параметры, увеличена концевая нагрузка (33 т), снижено удельное давление на грунт (0,92 кгс/см²), повышен ресурс работы рельсов и роликового круга.

Еще одна приятная новость - на Уралмашзаводе ведется активная работа над заказом по производству шахтной подъемной машины (ШПМ) для Гайского ГОКа (входит в УГМК-Холдинг). Летом 2018 г. машина поступит заказчику. В России в настоящий момент это единственное предприятие, которое изготавливает шахтные подъемные машины.

Для разработки первой уралмашевской ШПМ была создана специальная группа, в состав которой вошли опытные инженеры из нескольких подразделений предприятия. За их плечами успешная реализация различных проектов, в том числе строительство «под ключ» комплекса фабрики окомкования на Михайловском ГОКе.

Приступая к работе, специалисты УзтМ понимали, что машины будут востребованы. Сегодня на российских предприятиях эксплуатируется порядка 1000 шахтных подъемных машин. Ежегодно до четырех из них нуждаются в реконструкции или замене. Еще по две машины в год требуются для строительства новых шахт.

Посколькуаналогичное оборудование в России сегодня не производится, реализация этого проекта важна не только для Уралмашзавода и Гайского ГОКа, но и для экономики страны в целом. Это всех технологических параметров работы на пульте оператора, необходимыми защитами и блокировками, которые позволят избегать ошибок в работе оборудования и персонала.

На секции «Горноперерабатывающее оборудование» рассматривались такие темы, как развитие и совершенствование дробильно-размольного оборудования, выпускаемого ПАО «Уралмашзавод». Были также заслушаны доклады представителей Учалинского ГОКа, ГТО ООО «НИОГР», ОАО «Уралмеханобр», ИГД УрО РАН.

Своим заказчикам ПАО «Уралмашзавод» предлагает широкий размерный ряд конусных дробилок, крупного, редукционного, среднего и мелкого дробления, щековые дробилки. С 1935 г. предприятием изготовлено около 3000 дробилок, которые устойчиво работают как за Полярным кругом, так и в тропиках; на дробильных фабриках и непосредственно на карьерах; на переработке любых типов горных пород; на горнообогатительных предприятиях металлургии, в алмазодобывающей и горнохимической индустриях, а также в производстве нерудных материалов.

В настоящее время к гамме выпускаемого заводом дробильно-размольного оборудования добавляются щековые дробилки с простым и сложным качанием щеки. Новые модели ЩДС-12×15У ЩДС-9×12У оснащены гидравли-

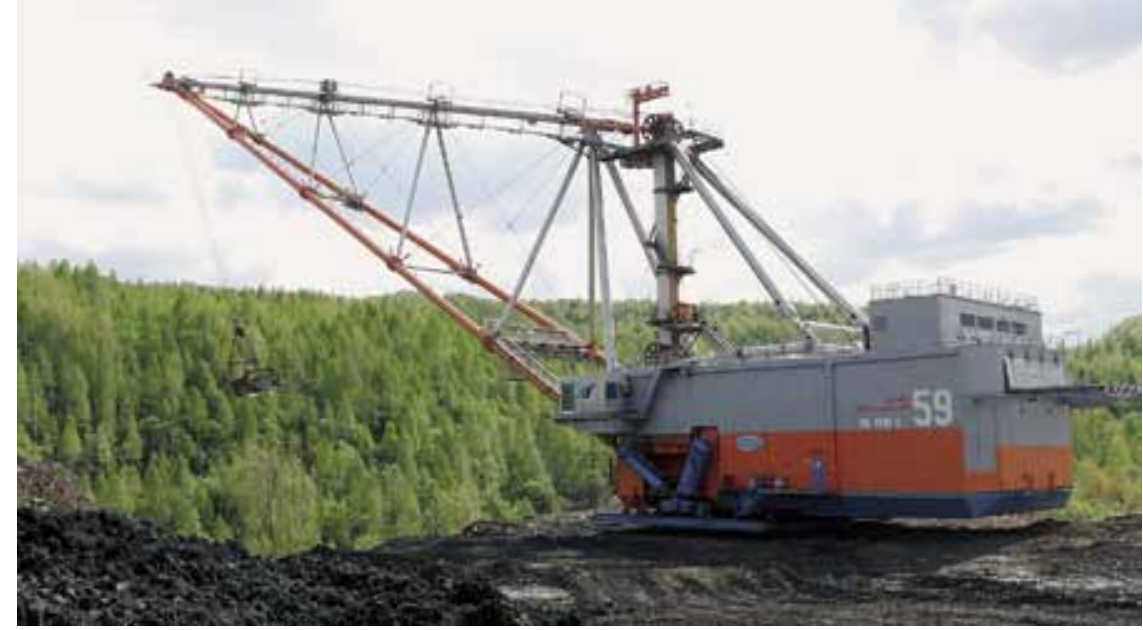

ЭШ-0.90С - одна из самых современных и высокопроизводительных машин в своем классе, спроектированная и изготовленная специально для работы в самых сложных горно-геологических и климатических условиях (разрез «Красногорский», ПАО «Южный Кузбасс») 
ческой системой дистанционного регулирования щели, усиленными подшипниковыми узлами, системой ЦАСС и АСУ. Можно сказать, что УЗТМ создает конкуренцию для импортных дробилок.

Для предприятий рудной и строительной промышленности, щебеночных карьеров и комплексов на Уралмашзаводе начали проектирование и подготовку к производству высокопроизводительных дробильных агрегатов типа «Гидроконус» большой единичной мощности (табл. 2). В России такое оборудование нигде больше не производится.

В 2017 г. Уралмашзавод выиграл тендер на поставку двух дробилокдля РуПП «Гранит» (Республика Беларусь) - крупнейшего предприятия в Европе по добыче и переработке плотных горных пород. Победа в тендере - это продолжение давнего сотрудничества Уралмашзавода и РУПП «Гранит». Парк горного оборудования заказчика практически полностью состоит из машин производства Уралмашзавода.

Среди крупных совместных проектов последних лет строительство дробильно-сортировочного завода РуПП «Гранит», технологической линии по производству кубовидного щебня - самого практичного и востребованного материала для строительства дорог.Дробильно-сортировочный завод был поставлен заказчику «под ключ»: Уралмаш отвечал не только за комплексную поставку всего оборудования, но и за достижение всех заявленных технологических показателей. Пуск в эксплуатацию состоялся в 2012 г., производительность технологической линии составляет 3 млн куб. м щебня в год. В октябре 2017 г. РУПП «Гранит» подтвердило, что технологическая линия работает надежно и выдает 3 млн куб. м щебня в год.

В 2016 г. Уралмашзавод поставил белорусскому заказчику две дробилки среднего дробления КСД-2200Гр-ВД. Оборудование введено в эксплуатацию и успешно работает. Сейчас Уралмашзавод изготовит для РУПП «Гранит» две дробилки среднего дробления КСД-2200Гр-ВД.

\section{УК «УЗТМ-КАРТЭКС» ПОЛУЧИЛА КОНТРОЛЬ НАД ОМЗ - ЛИТЕЙНОЕ ПРОИЗВОДСТВО»}

Присоединение к Группе - часть долгосрочной стратегии развития промышленных активов «Газпромбанка», конечная цель которой - создание успешного промышленного кластера по производству техники для добычи и переработки полезных ископаемых.

В рамках Группы изменится оперативное и операционноеуправление процессами:упростятся торгово-закупочные процедуры, появится возможность сквозного контроля качества, что положительно отразится на сроках поставок и расширении продуктовой линейки предприятия.

Литейное производство в Колпино - уникально, поскольку позволяет производить крупное литье, аналогов которому нет в России, необходимое под нужды конкретного предприятия. Ожидается, что качественной заготовкой будет обеспечен не только Уралмашзавод, но и ряд других промышленных предприятий. Для уральских машиностроителей это событие имеет колоссальное значение еще и потому, что портфель заказов УзТМ в последние годы изменился. Поми-
Таблица 2

Инновационные высокопроизводительные дробилки «Гидроконус»

\begin{tabular}{l|c|c|c|}
\hline \multicolumn{1}{|c|}{ Показатели } & КГМД & КГСД & ККД \\
\hline $\begin{array}{l}\text { Приемное отверстие, мм } \\
\text { Размер продукта, мм }\end{array}$ & $11\left(\mathrm{P}_{80}\right)$ & $85\left(\mathrm{P}_{80}\right)$ & $300\left(\mathrm{P}_{95}\right)$ \\
\hline $\begin{array}{l}\text { Диаметр основания конуса, мм, } \\
\text { не менее }\end{array}$ & 2000 & 2000 & 2520 \\
\hline $\begin{array}{l}\text { Диапазон регулирования } \\
\text { разгрузочной щели, мм }\end{array}$ & $8-20$ & $20-70$ & $140-215$ \\
\hline $\begin{array}{l}\text { Производительность (при насып- } \\
\text { ной плотности 2,25 т/куб. м), т/ч, } \\
\text { не менее }\end{array}$ & 800 & 1500 & 6000 \\
\hline $\begin{array}{l}\text { Мощность электродвигателя } \\
\text { главного привода, кВт, не менее }\end{array}$ & 750 & 750 & 500 \\
$\begin{array}{l}\text { Масса дробилки (без комплектов } \\
\text { запасных частей инструмента } \\
\text { и принадлежностей), т, не более }\end{array}$ & 110 & 110 & 500 \\
\hline
\end{tabular}

мо производства экскаваторов, где доля крупного литья составляет всего 15\%, предприятие обеспечено заказами на горное оборудование (различного типа дробилки, мельницы), где на долю крупного литья приходится почти 80\%. Поэтому присоединение актива «ОМ3-Литейное производство» к управляющей компании Уралмаша - это стратегический шаг в будущее.

Во второй день участники конференции посетили цеха Уралмашзавода и познакомились с производством серийных экскаваторов ЭКГ-18(20) для отечественных горнодобывающих предприятий, сборкой шагающего драглайна ЭШ 11.75, производством подъемно-транспортного, атомного и другого вида оборудования.

\section{ЗАКЛЮЧЕНИЕ}

Выступления с докладами, их обсуждение и общее настроение участников конференции показали наличие большого инновационного потенциала руководящего персонала и специалистов Уралмашзавода. В состав предприятия входят сварочное, механосборочное, термическое и инструментальное производства.

В этом году на конференции презентовались новые разработки [2]: крупный гидравлический экскаватор УГЭ-300, который сейчас находится в производстве предприятия, новые модели электрических экскаваторов ЭКГ-15 и

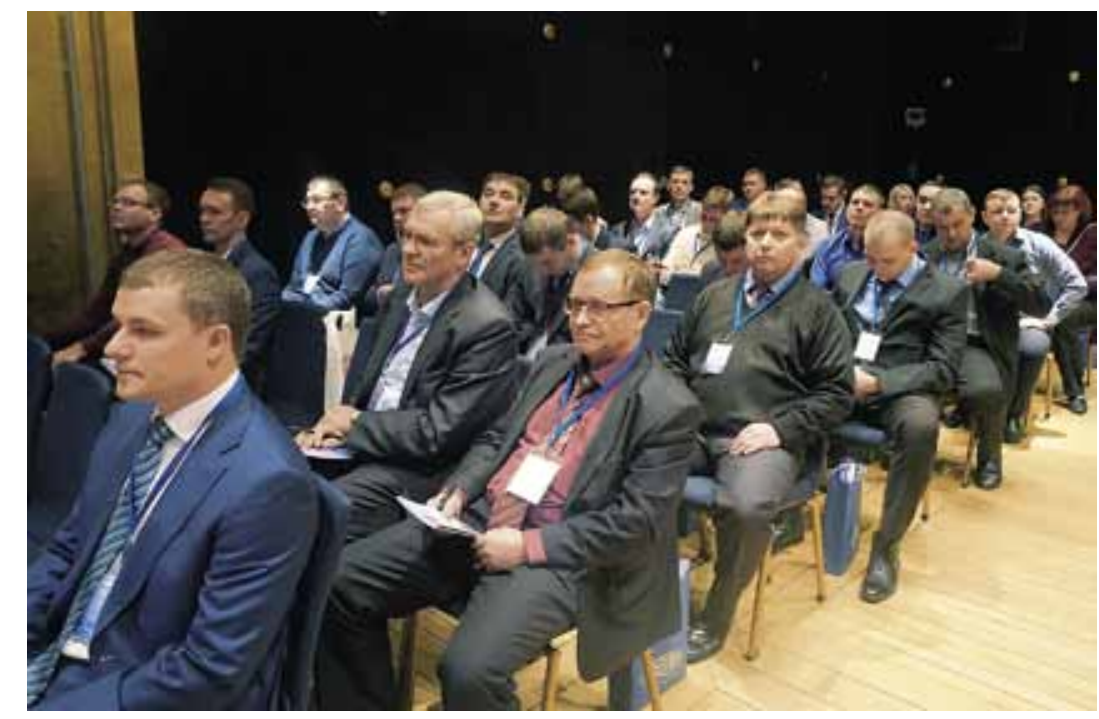


ЭКГ-25, а также первые наработки по новому виду оборудования для УзТМ - шахтной подъемной машины для Гайского ГОКа (УГМКХолдинг). Также здесь обсуждался успешный опыт эксплуатации модернизированных конусных и щековых дробилок на отечественных предприятиях, подводились итоги работы модернизированных шагающих экскаваторов, оценивались результаты работы серийных карьерных экскаваторов на примере ЭКГ-18(20).

Уралмашзавод предлагает заказчикам комплексные решения: от разработки технологий, инжиниринга до поставки, монтажа и сервисного обслуживания оборудования [6]. Техника завода высокопроизводительна, надежна, неприхотлива в эксплуатации, имеет высокий уровень автоматизации и создается с учетом современных экологических требований.

\section{Список литературы}

1. Глинина О.И. II Международная научно-практическая конференция «Открытые горные работы в XXI веке»: итоги работы // Уголь. 2015. № 12. С. 4-16. URL: http://www. ugolinfo.ru/Free/122015.pdf (дата обращения: 15.12.2017).

2. Продукция и услуги. URL: https://www.uralmash.ru (дата обращения 15.12.2017).

3. Баранов С.Л., Липатников А.А., Смирных К.В. Карьерный экскаватор Уралмашзавода побил рекорд в Кузбассе//Уголь. 2017. № 11. С.4-7.

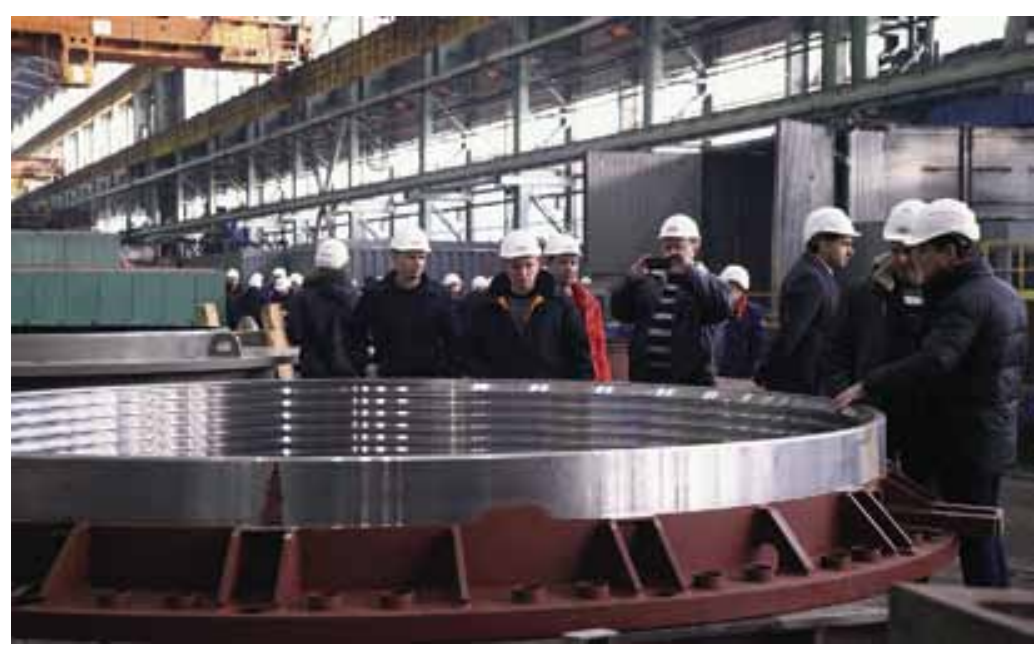

4. Глинина О.И. Импортозамещение - поддержка отечественного промышленного комплекса // Уголь. 2017. № 1. C.10-14. doi: 10.18796/0041-5790-2017-01-10-14.

5. Анистратов К.Ю. Карьерные экскаваторы - гидравлика или канат? // Уголь. 2010. № 6. С.31-35. URL: http://www.ugolinfo.ru/Free/062010.pdf (дата обращения 15.12.2017).

6. Уралмашзавод зашел на рынок Caterpillar и Hitachi. Горнякам обещают падение цен. «Заказчики подтверждают свой интерес к новой технике. URL: http://pravdaurfo.ru/ articles/159481-uralmashzavod-zashel-na-rynok-caterpillar-i (дата обращения 15.12.2017).

SURFACE MINING

UDC 061.3:621.879.3:622.271.4 @ O.I. Glinina, 2018

ISSN 0041-5790 (Print) • ISSN 2412-8333 (Online) • Ugol' - Russian Coal Journal, 2018, № 2, pp. 10-15

Title

URALMASHPLANT AND GAZPROMBANK: INTEGRATED SOLUTIONS FOR MINING INDUSTRY

DOI: http://dx.doi.org/10.18796/0041-5790-2018-2-10-15

Author

Glinina O.I. ${ }^{1}$

${ }^{1}$ Ugol' Journal Edition LLC, Moscow, 119049, Russian Federation

\section{Authors' Information}

Glinina O.I., Mining Engineer, Leading Editor of the Russian Coal Journal (Ugol'), e-mail: ugol1925@mail.ru

\section{Abstract}

The article provides basic information on III conference "Uralmashplant and Gazprombank: Integrated Solutions for Mining Industry", which was held in Ekaterinburg on November 23-24, 2017. The conference is attended annually by representatives of the topmost Russian mining and metallurgical enterprises, as well as profile engineering companies. The plenary session and two sections of the conference dealt with a wide range of issues: modern mining equipment, import substituting products, innovative technologies and their effectiveness. They discussed the main trends of open-pit mining and ore-preparation technologies development, mining equipment product line development strategy, complex deliveries advantages. Excavating, crushing and grinding equipment specific conference divisions were active within the conference scope.

\section{Keywords}

Uralmashplant, Mining industry, Mining machinery, Innovation technologies, Surface mining, Dredge, Ore preparation, Crushing and grinding equipment.

\section{References}

1. Glinina O.I. II Mezhdunarodnaya nauchno-prakticheskaya konferentsiya Otkrytye gornye raboty $v$ XXI veke itogi raboty [II International theoretical and practical conference "Surface mining in XXI century": Summary record ]. Ugol' - Russian Coal Journal, 2015, No. 12, pp. 4-16. Available at: http://www. ugolinfo.ru/Free/122015.pdf (accessed 15.12.2017).

2. Produktsiya i uslugi [Products and services]. Available at URL: https://www. uralmash.ru (accessed 15.12.2017).

3. Baranov S.L., Lipatnikov A.A., Smirnykh K.V. Karernyy ekskavator Uralmashzavoda pobil rekord $v$ Kuzbasse [Uralmashplant open-pit excavator broke record in Kuzbass]. Ugol' - Russian Coal Journal, 2017, No. 11, pp.4-7.

4. Glinina O.I. Importozameshchenie podderzhka otechestvennogo promyshlennogo kompleksa [Import substitution - domestic industrial complex support]. Ugol' - Russian Coal Journal, 2017, No. 1, pp. 10-14. doi: 10.18796/00415790-2017-01-10-14.

5. Anistratov K.Yu. Karernye ekskavatory gidravlika ili kanat? [Career dredges hydraulics or a rope?]. Ugol' - Russian Coal Journal, 2010, No. 6, pp. 31-35. Available at: http://www.ugolinfo.ru/Free/062010.pdf (accessed 15.12.2017). 6. Uralmashzavod zashel na rynok Caterpillar i Hitachi Gornyakam obeshchayut padenie tsen Zakazchiki podtverzhdayut svoy interes k novoy tekhnike [Uralmashplant entered Catepillar and Hitachi market. Miners are promised price collapse. Customers confirm their interest to new machinery]. Available at: http://pravdaurfo.ru/articles/159481-uralmashzavod-zashel-na-rynokcaterpillar-i (accessed 15.12.2017). 


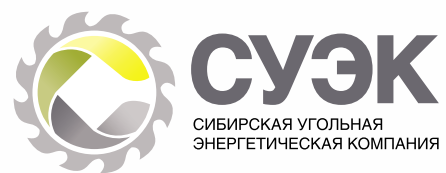

ЭНЕРГЕТИЧЕСКАЯ КОМПАНИЯ

\section{На «Восточно-Бейском разрезе» установлен новый мировой рекорд}

Коллектив ООО «Восточно-Бейский разрез» (Сибирская угольная энергетическая компания) 19 января 2018 г. чествовал экипаж экскаватора Komatsu PC 1250 SP № 5 в составе бригадира Евгения Журавина, машинистов Сергея Лощинина, Виталия Карчигашева, Степана Абдулина. Поводом для торжества стал мировой рекорд по отгрузке горной массы в автосамосвалы в объеме 517,5 тыс. куб. м за месяц.

Этого результата бригада достигла в декабре 2017 г. Поставщик техники - «Сумитек Интернейшнл» - в своем письме сообщил, что результат работы бейских горняков «является наивысшим показателем производительности для машин данного класса, работающих на угольных разрезах всего мира».

«В новом рекорде экипажа Евгения Журавина хочется отметить эффрективное и бережное отношение к технике, - говорит генеральный директор ООО «СУЭК-Хакасия» Алексей Килин. - Бригада уже не первый год эксплуатирует экскаватор, при этом обеспечивает высокий коэффициент использования техники, что позволило ей работать на уровне лучших мировых достижений не только в рамках месяча, но и в целом по 2017 году».

«На «Восточно-Бейском разрезе» установлено уже 7 мировых рекордов, из них три приходятся на долю экипажа экскаватора Komatsu PC 1250 SP № 5, - отметил исполнительный директор ООО «Восточно-Бейский разрез» Денис Попов. Предыдущий рекорд по отгрузке горной массы в автосамосвалы за месяц бригада под руководством Е. Журавина установила ровно год назад. Тогда этот показатель составил 422,8 тыс. куб. м; таким образом, рост максимальной производительности составил более 20 прочентов».

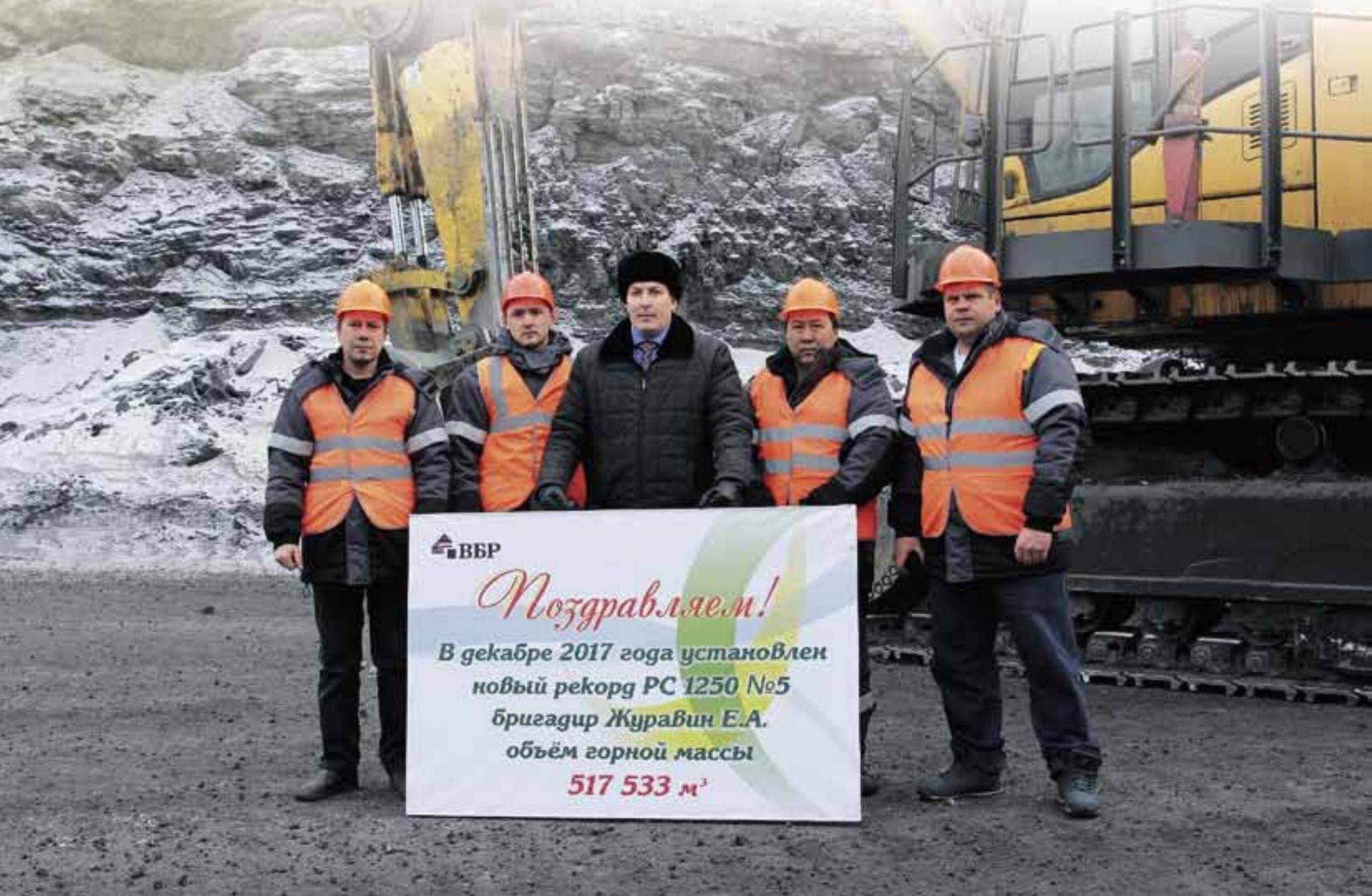




\section{0 «Сибэнергоуголь» - предприятие с открытой добычей угля включилось в вахту производственных достижений}

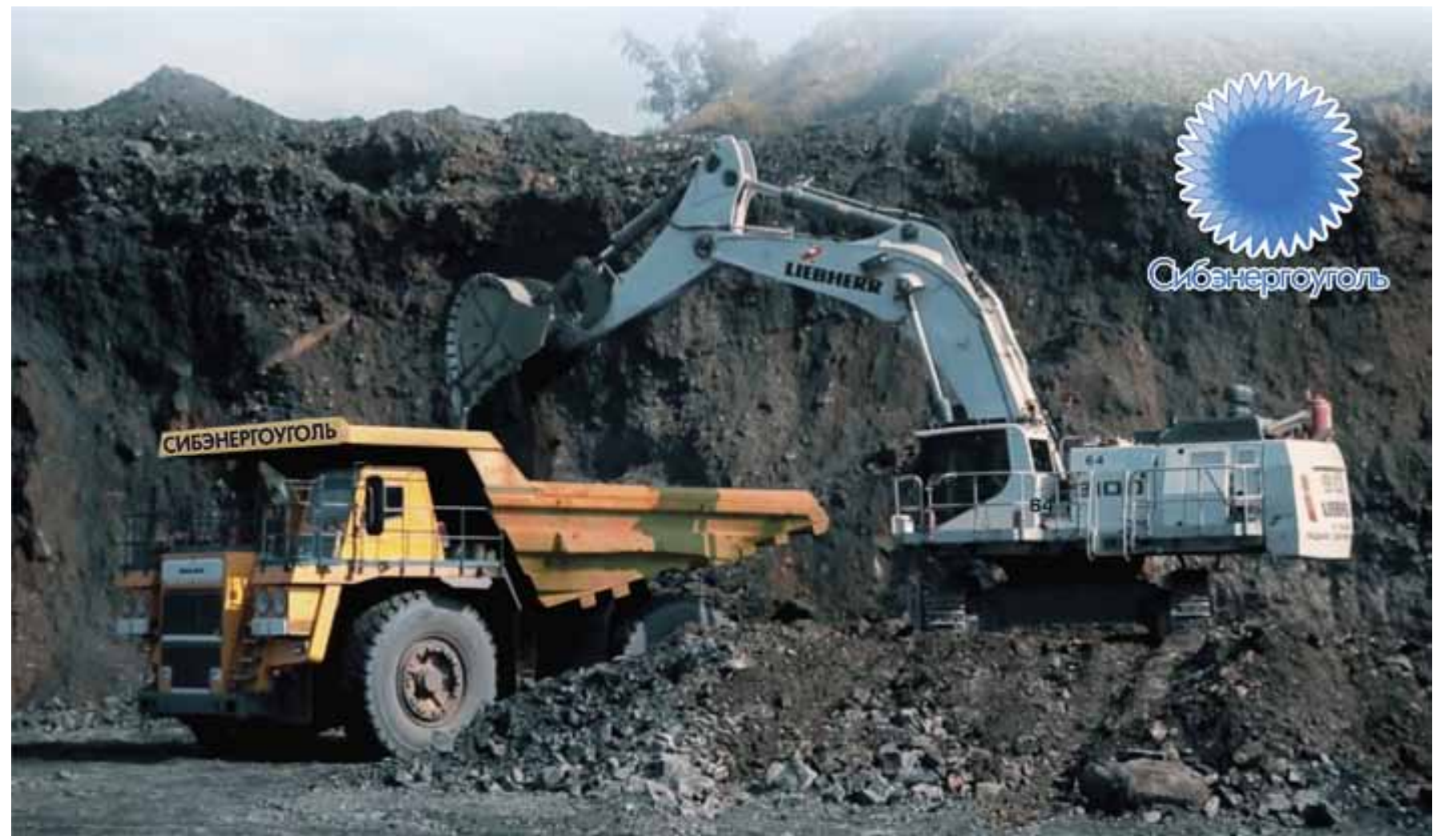

В 2017 г. установлено несколько рекордов по добыче угля и отгрузке горной массы. Ярким примером стал результат экипажа экскаватора Liebherr R 9100 № 36064 во главе с бригадиром Литвиновым Николаем Юрьевичем.

Благодаря проявленному высокому профессионализму экипажа Liebherr R 9100 достигнут рекордный показатель по объему отгрузки горной массы в автотранспорт в объеме 3005745 куб. м. Теперь Всероссийский рекорд станет новым ориентиром для горняков.
Подведение итогов состоялось на собрании коллектиВа, где генеральный директор ООО «Сибэнергоуголь» $\boldsymbol{B a}$ лерий Васильевич Устинов поблагодарил за безопасную и производительную работу, вручил грамоты и денежные премии, а горняки в свою очередь пообещали продолжить вахту производственных достижений.

Желаем коллективу ООО «Сибэнергоуголь» не останавливаться на достигнутых результатах и в будущем добиться еще более высоких производственных показателей.

\section{Харанорский разрез установил российский рекорд}

Новый российский рекорд по переработке горной массы установлен на Харанорском разрезе, входящем в состав АО «Сибирская угольная энергетическая компания» (СУЭК). За 12 мес.

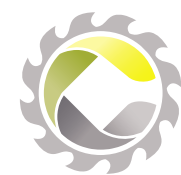
2017 г. экипаж экскаватора ЭКГ-12,5 № 82 под руководством бригадира Андрея Рыжакова отгрузил в автотранспорт свыше 5,3 млн куб. м вскрышной породы.

Настолько высокий показатель на подобной технике достигнут впервые. Предыдущий российский рекорд 5,25 млн куб. м - был установлен на этой же машине в 2015 г. Экипажу Андрея Рыжакова также принадлежит российский рекорд месячной отгрузки: в июне того же года он переместил в отвалы 602 тыс. куб. м горной массы, что вдвое превышает установленную для данного типа экскаваторов норму. Тогда за выдающиеся производственные результаты СУЭК отметила экипаж автомобилем Ford Mondeo.

Достижению нынешнего высокого показателя способствовала плановая стабильная работа многих подразделе- ний. Например, была усовершенствована система разработки месторождения, внедрена новая технология погрузки, позволившая значительно сократить время на производство вскрышных работ. КроСИБИРСКАЯ УГОЛЬНАЯ ме того, на разрезе ведутся постоянная модернизация и
обновление технологического парка. Так, в ходе модернизации на экскаваторе ЭКГ-12,5 № 82 была установлена современная цифровая система управления. По инвестиционной программе СУЭК в 2017 г. на предприятие поступили автосамосвал БелАЗ, колесный бульдозер ТК-25, два грейдера, автомобильный кран КАТО.

В 2018 г. харанорские горняки ждут еще один БелАЗ, экскаватор, буровую установку, седельный тягач, универсальную дорожную машину. Наращивание технической мощи способствует увеличению производственных объемов: в 2018 г. перед предприятием стоит задача - выполнить годовой план по добыче угля в объеме 3,2 млн т - это на 200 тыс. т больше, чем в 2017 г. 


\section{Разрез «Изыхский» получил новый экскаватор Komatsu PC 1250}

На разрезе «Изыхский» (Хакасия) Сибирской угольной энергетической компании состоялся торжественный ввод в эксплуатацию нового экскаватора Komatsu PC 1250 .

«Поставка современной новой техники - это свидетельство заслуг коллектива и уверенности руководства компании в том, что новая машина даст дополнительные возможности горнякам разреза «Изыхский» укрепить стабильность своего предприятия, на новый уровень вывести эффективность и безопасность производства», - говорит генеральный директор ООО «СУЭК-Хакасия» Алексей Килин.

Торжественный ввод новой техники в эксплуатацию является традицией предприятия. В декабре 2017 г. аналогичным образом был дан старт работе нового бульдозера Liebherr 764: красную ленточку перерезают бригадир экипажа и генеральный директор разреза «Изыхский»; затем в присутствии коллектива звучат напутственные слова руководителей об эффективном и бережном использовании новой машины.

В прошедшем 2017 году коллектив разреза «Изыхский» уже к 17 ноября выполнил годовой план, всего же за год добыча составила 1 млн 252 тыс. т угля.

\section{Наша справка.}

АО «СУЭК»-одна из ведущихугледобывающих компаний мира, крупнейший в России производитель угля, крупнейший поставщик на внутренний рынок и на экспорт. Добывающие, перерабатывающие, транспортные и сервисные предприятия СУЭК расположены в восьми регионах России. На предприятиях СУЭК работают более 33500 человек. Основной акционер - Андрей Мельниченко.

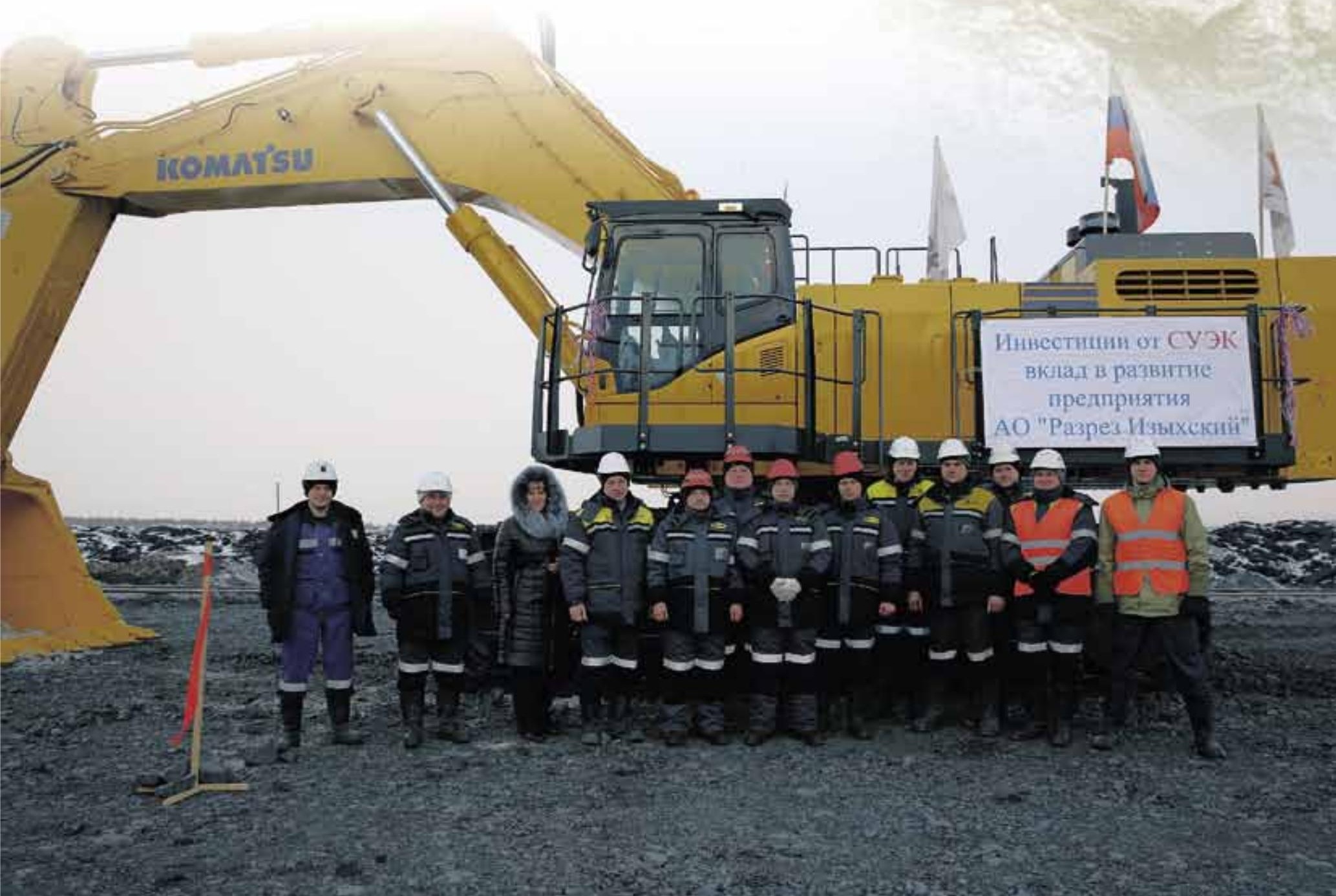




\section{Поиск новых возможностей повышения}

\section{безопасности и эффективности автотранспортных подразделений АО «СУЭК»}

DOI: http://dx.doi.org/10.18796/0041-5790-2018-2-20-23

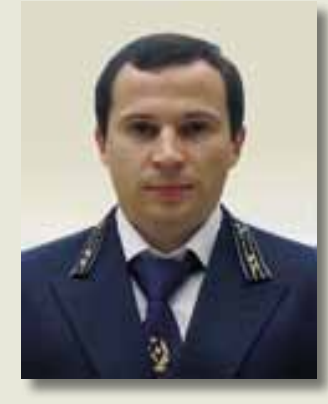

ИСАЙЧЕНКОВ

Александр Борисович

Канд. техн. наук, начальник отдела технического обеспечения и технологии ОГР $A O$ «СУЭК», 115054, г. Москва, Россия e-mail:IsaychenkovAB@suek.ru

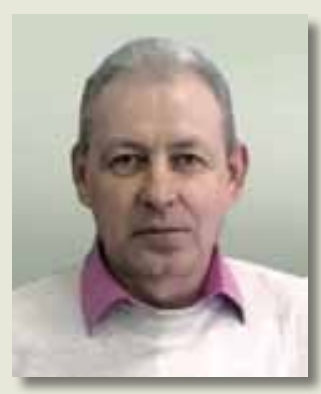

ДОВЖЕНОК Александр Сергеевич Доктор техн. наук, ведущий научный сотрудник 000 «НИИОГР», 454048, г. Челябинск, Россия, тел.: +7 (351) 2161792 , e-mail:dovgenok@bk.ru

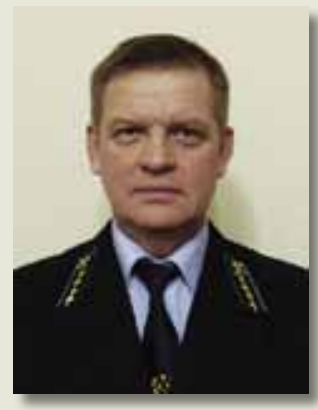

\section{CTEПАНОВ}

Александр Александрович Начальник АТЦ АО «Разрез Березовский», 662305, г. Шарыпово, Россия

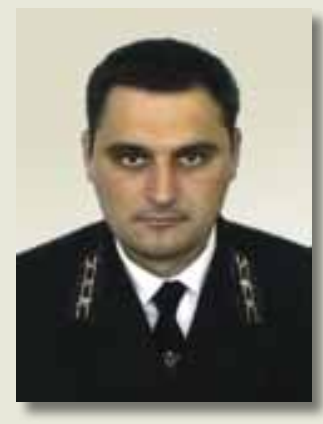

\section{РОЖЕНКО}

Виктор Викторович

Начальник

автотранспортного цеха

Ру «Новошахтинское»

ООО «Приморскуголь», 692656, пос. Новошахтинский, Приморский край, Россия, тел.: +7 (42346) 25845, доб. 3-03
23-27 октября 2017 г. состоялось шестое ежегодное совещание автомобилистов СУЭК по повышению безопасности и эффективности производственных процессов на транспорте, которое в этот раз проходило на заводе БелАЗ. Важным аспектом было обсуждение конструктивных доработок карьерных автосамосвалов, поскольку СУЭК является стратегическим партнером завода. Ключевой темой совещания руководителей и специалистов была проработка концепции программы развития автотранспортного подразделения как системы, являющейся важным звеном в технологической цепи угледобычи. Такой подход позволил увидеть новые возможности повышения безопасности и эффективности производства.

Ключевые слова: совещание автомобилистов, безопасность и эффективность производства, автотранспортная системаугледобывающего предприятия, концепция программы развития, рейтинги.

\section{ВВЕДЕНИЕ}

С 23 по 27 октября 2017 г. состоялось шестое ежегодное совещание автомобилистов СУЭК по повышению безопасности и эффективности производства, которое проходило в Республике Беларусь (г. Жодино). Участниками совещания были представители головного офиса компании СУЭК, руководители и специалисты автотранспортных подразделений производственных единиц, руководители сервисных предприятий и партнеров СУЭК, сотрудники НИИОГР - всего более 50 человек.

\section{ОСНОВНЫЕ АСПЕКТЫ СОВЕЩАНИЯ}

Проведено ознакомление с заводом БелАЗ, по завершении которого с заместителями генерального директора, главного конструктора и начальниками конструкторских бюро (13 чел.) были обсуждены слабые конструктивные места, выявленные на автосамосвалах БелАЗ в процессе их эксплуатации на предприятиях СУЭК и предложения по улучшению качества машин. Представители завода вынесли на обсуждение конструктивные изменения в автосамосвалах грузоподъемностью 130-220 т, осуществленные в период 2012-2017 гг.

Состоялось рассмотрение семнадцати докладов руководителей автотранспортных участков и цехов СУЭК о результатах улучшений в своих подразделениях за 2017 г. В выступлениях участников отмечен высокий уровень внимания со стороны Компании к обеспечению средствами механизации вспомогательных и трудоемких процессов, а также позитивная динамика в росте культуры производства и результатах деятельности [1, 2]. В выступлениях руководителей сторон- 
них сервисных предприятий (четыре доклада) были даны предложения по сотрудничеству, обеспечивающие взаимную выгоду сторон.

Дискуссия в отношении мер по повышению качества рабочих процессов при эксплуатации и ремонте машин наглядно показала участникам, что основные резервы сосредоточены в управлении производством. Если величину этих резервов принять за 100\%, то, по мнению участников, по функциям управления: планирование (П), организация (О), мотивация (М) и контроль (К) резервы распределяются следующим образом: П - 20\%, О - 50\%, М и К - по 15\%. Основные резервы - 70\% - в планировании и организации производства.

Участниками отмечено, что у автомобилистов возрастает уровень заинтересованности в объединении усилий в области повышения безопасности и эффективности функционирования автотранспортных подразделений.

Ключевой аспект совещания - обсуждение концепции программы развития автотранспортной системы угледобывающего предприятия.

В 2013 г. СУЭК была разработана и принята стратегия по развитию автотранспорта. Для улучшения деятельности по освоению стратегии на совещании была предложена и обсуждена концепция программы развития автотранспортной системы как важнейшего звена в технологической цепи угледобывающего предприятия [3]. Обсуждение этой концепции позволило участникам уяснить, что главным в ней является развитие профессионализма персонала, в первую очередь руководителей автотранспортных цехов, до уровня, обеспечивающего требуемую динамику безопасности и эффективности производства $[4,5]$.

\section{ТРАДИЦИОННЫЙ АСПЕКТ СОВЕЩАНИЯ - \\ ОПРЕДЕЛЕНИЕ РЕЙТИНГОВ}

Расчет рейтингов предприятий показал высокий интерес к этому этапу работы совещания, поскольку позволяет увидеть результаты функционирования своих подразделений среди других.

По принятым на предыдущих совещаниях ключевым показателям соревнования: удельные затраты труда, чел.-ч/ маш.-ч на линии; удельная производительность автосамосвалов, тыс. т/авто-тонну и тыс. т·км/авто-тонну; удельные затраты на $1 \mathrm{~m}^{3}$ перевезенной горной массы и 1 т·км, руб./м³ и руб./т·км; травматизм - количество несчастных случаев и их тяжесть определен рейтинг автотранспортных подразделений разрезов [6]. Места распределились следующим образом (табл. 1).

\section{КОНЦЕПЦИЯ ПРОГРАММЫ РАЗВИТИЯ автотранспортной системы угледобывающего предприятия}

Автотранспортная система - это важнейшее звено угледобывающего предприятия в его технологической цепи. Она включает подсистемы эксплуатации и ремонта автосамосвалов, функционирование и развитие которых обеспечивают руководители, специалисты и операторы.

Предназначение автотранспортной системы - обеспечение безопасных и эффективных грузопотоков на основе рационального использования ресурсов предприятия.

Цель программы - формирование устойчиво и динамично развивающейся автотранспортной системы на основе роста профессионализма персонала и прежде всего руководителей.

Критерии результативности - требуемая динамика повышения качества транспортной услуги и обеспечение снижения ее стоимости в сравнении с конкурентами.

\section{Основные положения:}

- привлекательность автотранспортной системы для руководства Компании, РПО и ПЕ достигается наилучшим сочетанием цены и качества транспортной услуги на основе формирования высокой культуры производства и динамики развития автотранспортной системы;

- привлекательность для ее работников обеспечивается высокой культурой производства, возможностями удовлетворения своих профессиональных и социальноэкономических потребностей;

- основное требование к каждому руководителю, специалисту, оператору - постоянное развитие своего профессионализма.

\section{Эmanb:}

- социально-экономические улучшения - усиление мотивации к безопасному, эффективному и производительному труду, улучшение связи «результат - оплата» по всем категориям работников;

- организационное развитие - улучшение отношений к труду, предприятию; совершенствование функций и взаимодействия персонала по уровням управления; повышение культуры производства;

- технико-технологическая модернизация в эксплуатации и ремонте - обеспечение надежности оборудования, механизация трудоемких операций и процессов.

Результаты - высокая динамика развития автотранспортной системы с приемлемым уровнем:

- безопасности, производительности труда персонала и автосамосвалов;

- удельной себестоимости автоперевозок;

- культуры производства.

Таблича 1

Рейтинги предприятий

\begin{tabular}{|c|c|c|c|}
\hline \multicolumn{2}{|c|}{2016 г. } & & 9 мес. 2017 г. \\
\hline № места & Предприятие & № места & Предприятие \\
\hline 1 & Разрез «Березовский» & 1 & Разрез «Березовский» \\
\hline 2 & Разрез «Восточно-Бейский» & 2 & Разрез «Восточно-Бейский» \\
\hline 3 & Разрез «Тугнуйский» & 3 & Разрез «Тугнуйский», Разрез «Харанорский» \\
\hline 4 & Разрез «Изыхский» & 4 & Разрез «Изыхский» \\
\hline 5 & Разрез «Харанорский» & 5 & РУ «Новошахтинское» \\
\hline 6 & РУ «СУЭК-Кузбасс» & 6 & РУ «СУЭК-Кузбасс», Разрез «Черногорский» \\
\hline 7 & Разрез «Черногорский» & 7 & АО «Ургалуголь», Разрез «Апсатский» \\
\hline 9 & АО «Ургалуголь» & - & - \\
\hline 10 & РУ «Новошахтинское» & - & - \\
\hline
\end{tabular}


Основные результаты совещаний автомобилистов за 2012-2017 гг.

\begin{tabular}{|c|c|c|c|}
\hline \multirow{2}{*}{ Год и место } & \multicolumn{2}{|c|}{ Количество участников } & \multirow{2}{*}{ Результаты } \\
\hline & Предприятий & Человек & \\
\hline $\begin{array}{l}\text { 16-17.10.2012 г., } \\
\text { Разрез } \\
\text { «Восточно-Бейский» }\end{array}$ & 6 & $17 / 15$ & $\begin{array}{l}\text { Скорректирован стандарт работы экскаваторно-автомобильного ком- } \\
\text { плекса на разрезе «Восточно-Бейский». } \\
\text { Участники продемонстрировали заинтересованность в проведении по- } \\
\text { добных форумов для продуктивного обмена опытом и совместного реше- } \\
\text { ния общих проблем }\end{array}$ \\
\hline $\begin{array}{l}\text { 21-25.10.2013 г., } \\
\text { Разрез «Тугнуйский» }\end{array}$ & 9 & $34 / 32 / 1^{*}$ & $\begin{array}{l}\text { Разработан проект положения о соревновании автотранспортных цехов } \\
\text { (участков). } \\
\text { Участники увидели на предприятии много интересных улучшений }\end{array}$ \\
\hline $\begin{array}{l}\text { 6-11.10.2014 г., } \\
\text { Разрез «Березовский» }\end{array}$ & 11 & $19 / 17 / 1$ & $\begin{array}{l}\text { Начался реальный обмен опытом - ряд полезных улучшений руководи- } \\
\text { тели внедрили у себя на производстве без привлечения дополнительных } \\
\text { инвестиций. } \\
\text { Оценена деятельность автотранспортных цехов (участков) за прошедший } \\
\text { период, что вызывает соревновательный эффект и позволяет руководите- } \\
\text { лям обоснованно сравнивать себя с другими руководителями аналогич- } \\
\text { ных подразделений }\end{array}$ \\
\hline $\begin{array}{l}\text { 14-18.09.2015 г., } \\
\text { ОАО «Приморскуголь» }\end{array}$ & 11 & $25 / 24 / 1$ & $\begin{array}{l}\text { Расширяется внедрение полезных улучшений. } \\
\text { Принято, что необходимо освоение всем персоналом автотранспортных } \\
\text { подразделений безопасной культуры производства как основы его эф- } \\
\text { фективности. } \\
\text { Подведены итоги соревнований автотранспортных цехов, что усиливает } \\
\text { интерес к проведению совещаний }\end{array}$ \\
\hline $\begin{array}{l}\text { 24-29.10.2016 г., } \\
\text { АО «СУЭК-Кузбасс» }\end{array}$ & 18 & $40 / 27 / 3$ & $\begin{array}{l}\text { Продемонстрировано освоение безопасной культуры производства в мо- } \\
\text { бильном ремонтном боксе на основе повышения уровня чистоты, поряд- } \\
\text { ка и организации процессов. } \\
\text { Уяснено, что необходимо перейти к системе непрерывных улучшений в цехах }\end{array}$ \\
\hline $\begin{array}{l}\text { 23-27.10.2017 г., } \\
\text { Минск, завод БелАЗ }\end{array}$ & 19 & $50 / 34 / 15$ & $\begin{array}{l}\text { С руководством завода БелАЗ проведено совещание по конструктивным } \\
\text { улучшениям карьерных автосамосвалов. } \\
\text { Обсуждена Концепция развития автотранспортных подразделений } \\
\text { на основе роста профессионализма персонала и прежде всего } \\
\text { руководителей, }{ }^{* *} \text { которая принята как Программа }\end{array}$ \\
\hline
\end{tabular}

Необходимо отметить, что с 2015 г. в тройке передовиков сохраняют свои позиции разрезы «Березовский», «Восточно-Бейский», «Тугнуйский» $[7,8]$.

\section{ОСНОВНЫЕ РЕЗУЛЬТАТЫ СОВЕЩАНИЙ}

\section{3А 2012-2017 гг.}

Компанией ведется целенаправленная работа по сплочению руководителей автотранспортных подразделений в регулярно функционирующую организационную структуру по эффективному обмену опытом, идеями и замыслами, по совместному поиску методов решения общих проблем [9]. Значимое место в формируемой структуре занимает ежегодное совещание автомобилистов, которое позволяет подвести итоги и наметить план на будущее. Основные результаты этой работы за период с 2012 по 2017 г. представлены в табл. 2.

\section{ЗАКЛЮЧЕНИЕ}

Осуществление стратегии компании «СУЭК» по развитию карьерного автотранспорта предопределяет необходимость ускоренного повышения профессионализма персонала, и прежде всего руководителей транспортных цехов, до уровня, обеспечивающего требуемую динамику безопасности и эффективности производства на осно- ве подготовки и освоения соответствующей Программы. Участники совещания пришли к выводу, что для формирования устойчиво и динамично развивающейся автотранспортной системы целесообразно каждому заинтересованному руководителю автотранспортного подразделения подготовить и реализовать такую Программу.

\section{Список литературы}

1. Bowers M.R., Hall J.R., Srinivasan M.M. Organizational culture and leadership style: The missing combination for selecting the right leader for effective crisis management // Business Horizons. 2017. Vol. 60. Issue 4, p. 551-563.

2. Pollard J., Heberger J., Dempsey P.G. Maintenance and repair injuries in US mining //Journal of Quality in Maintenance Engineering. 2014. Vol. 20. Issue 1, pp. 20-31. doi: 10.1108/ JQME-02-2013-0008.

3. Кулецкий В.Н., Жунда С.В., Галкин А.В. Формирование эффективной системы производственного контроля на разрезе «Тугнуйский» для устранения условий труда, при которых возможны групповые, смертельные и тяжелые травмы // Уголь. 2017. № 2. С. 23-28. URL: http://www. ugolinfo.ru/Free/022017.pdf (дата обращения: 15.01.2018).

4. Роль руководителя и персонала в обеспечении безопасности производства / В.Б. Артемьев, В.В. Лисов- 
ский, А.И. Добровольский и др. Отдельная статья Горного информационно-аналитического бюллетеня. М.: Горная книга, 2017.48 с. (Сер. «Б-ка горного инженераруководителя». Вып. 32).

5. Phakathi S.T. Production, Safety and Teamwork in a DeepLevel Mining Workplace: Perspectives from the Rock-Face. Emerald Publishing Limited, 2017. 259 p.

6. Совещание автотранспортников ОАО «СУЭК» / B.Н. Кулецкий, А.В. Горохов, И.Б. Строгий, А.С. Довженок // Уголь. 2013. № 12. С. 14-16. URL: http://www.ugolinfo.ru/ Free/122013.pdf (дата обращения 15.01.2018).

7. Повышение безопасности и эффективности функционирования автотранспортных подразделений $\mathrm{AO}$ «СУЭК»
/ Ю.В. Примачев, А.В. Дьяконов, В.В. Роженко и др. // Уголь. 2015. № 11. С. 30-32. URL: http://www.ugolinfo.ru/ Free/112015.pdf (дата обращения 15.01.2018).

8. Повышение эффективности и безопасности функционирования автотранспортных подразделений ОАО «СУЭК» / А.С. Мануильников, А.А. Степанов, И.Б. Строгий и др. // Уголь. 2014. № 12. С. 48-49. URL: http://www.ugolinfo.ru/ Free/122014.pdf (дата обращения 15.01.2018).

9. Franco Jefferds dos Santos Silva, Herbert Ricardo Garcia Viana, André Nasser Aquino Queiroz. Availability forecast of mining equipment // Journal of Quality in Maintenance Engineering. 2016. Vol. 22. Issue 4, pp. 418-432. doi: 10.1108/ JQME-12-2015-0067.

UDC 061.3:622.684:656.13 @ A.B. Isaychenkov, A.S. Dovzhenok, A.A. Stepanov, V.V. Rozhenko, 2018

ISSN 0041-5790 (Print) • ISSN 2412-8333 (Online) • Ugol' - Russian Coal Journal, 2018, № 2, pp. 20-23

\section{Title}

SUEK, JSC TRANSPORTATION COMPANIES IN SEARCH FOR NEW SAFETY AND EFFICIENCY OPPORTUNITIES

DOI: http://dx.doi.org/10.18796/0041-5790-2018-2-20-23

\section{Authors}

Isaychenkov A.B. ${ }^{1}$, Dovzhenok A.S. ${ }^{2}$, Stepanov A.A. ${ }^{3}$, Rozhenko V.V. ${ }^{4}$

'SUEK, JSC, Moscow, 115054, Russian Federation

${ }^{2}$ Institute of efficiency and safety of mining production ("NIIOGR" LLC), Chelyabinsk, 454048, Russian Federation

3 "Berezovsky" Open-pit mine, JSC, Sharypovo, 662305, Russian Federation

${ }^{4} \mathrm{RU}$ "Novoshahtinskoe" of "Primorskugol" LLC, Novoshahtinskoe village, Primorsky Krai, 692656, Russian Federation

\section{Authors' Information}

Isaychenkov A.B., PhD (Engineering), Head of Department of surface mining, e-mail: IsaychenkovAB@suek.ru

Dovzhenok A.S., Doctor of Engineering Sciences, Leading Scientific Assistant, tel.: +7 (351) 216-17-92, e-mail: dovgenok@bk.ru

Stepanov A.A., Head of Department of transport

Rozhenko V.V., Head of Department of transport, tel.: +7 (42346) 2-58-45 ex. 3-03

\section{Abstract}

The sixth annual meeting of SUEK automotive specialists, was held on October 23-27, 2017, to improve safety and efficiency of transportation production processes; this time the meeting took place at the BelAZ plant. Mine dump trucks meaningful modifications was an important aspect of discussions, as SUEK is a strategic partner of the plant. The key topic of the managers and specialists meeting was the elaboration of the program concept for the development of road transport unit as an important coal mining process chain component. This approach highlighted new opportunities for safety and production efficiency improvement.

\section{Keywords}

Automotive specialists meeting, Production safety and efficiency, Coal mining enterprise motor transportation system, Development program concept, Ratings.

\section{References}

1. Bowers M.R., Hall J.R. \& Srinivasan M.M. Organizational culture and leadership style: The missing combination for selecting the right leader for effective crisis management. Business Horizons, 2017, Vol. 60(4), pp. 551-563.

2. Pollard J., Heberger J., Dempsey P.G. Maintenance and repair injuries in US mining. Journal of Quality in Maintenance Engineering, 2014, Vol. 20(1), pp. 20-31. doi: 10.1108/JQME-02-2013-0008.

3. Kuletsky V.N., Zhunda S.V. \& Galkin A.Val. Formirovanie effektivnoy sistemy proizvodstvennogo kontrolya na razreze «Tugnuyskiy» dlya ustraneniya usloviy truda, pri kotorykh vozmozhny gruppovye, smertel'nye i tyazhelye travmy [Efficient production monitoring system arrangement in "Tugnuisky" open-pit mine for elimination of the labor conditions, raising the possibility of group, fatal and severe injuries]. Ugol' - Russian Coal Journal, 2017, No. 2, pp. 23-28. Available at: http://www.ugolinfo.ru/Free/022017.pdf (accessed 15.01.2018).

4. Artemiev V.B., Dobrovolskiy A.I., Lisovskiy V.V., Galkin V.A., Makarov A.M., Kravchuk I.L., Kaledina N.O., Vorobyova O.V. \& Galkin A.V. Rol rukovoditelya i personala v obespechenii bezopasnostiproizvodstva [Manager's and personnel role in production safety provision]. Separate article in the Mining Information and Analytical Bulletin. Moscow, Gornaya Kniga Publ., 2017, 47 p. (Mining Engineer-Manager's Library series, issue 32)

5. Phakathi S.T. Production, Safety and Teamwork in a Deep-Level Mining Workplace: Perspectives from the Rock-Face. Emerald Publishing Limited, 2017, 259 p.

6. Kuletsky V.N., Gorokhov A.V., Strogiy I.B. \& Dovzhenok A.S. Soveshchanie avtotransportnikov OAO "SUEK" [Meeting of "SUEK" company motor transport unit employees]. Ugol' - Russian Coal Journal, 2013, No. 12, p. 14-16. Available at: http://www.ugolinfo.ru/Free/122013.pdf (accessed 15.01.2018).

7. Primachev Yu.V., Dyakonov A.V., Rozhenko V.V. \& Dovzhenok A.S. Povyshenie bezopasnosti i effektivnosti funktsionirovaniya avtotransportnykh podrazdeleniy AO "SUEK" [Improving Safety and Efficiency of Operation of SUEK's Motor Divisions]. Ugol' - Russian Coal Journal, 2015, No. 11, pp. 30-32. Available at: http://www.ugolinfo.ru/Free/112015.pdf (accessed 15.01.2018). 8. Manuilnikov A.S., Stepanov A.A., Strogiy I.B. \& Dovzhenok A.S. Povyshenie effektivnosti i bezopasnosti funktsionirovaniya avtotransportnykh podrazdeleniy OAO "SUEK" [Improving the Efficiency and Safety of the Motor Transport Departments of "SUEK" JSC]. Ugol' - Russian Coal Journal, 2014, No. 12, pp. C. 48-49. Available at: http://www.ugolinfo.ru/Free/122014.pdf (accessed 15.01.2018).

9. Franco Jefferds dos Santos Silva, Herbert Ricardo Garcia Viana, André Nasser Aquino Queiroz. Availability forecast of mining equipment. Journal of Quality in Maintenance Engineering, 2016, Vol. 22(4). pp. 418-432. doi: 10.1108/ JQME-12-2015-0067. 


\title{
БИЗНЕС МАСЕЛ ЛУКОЙЛ: ПОЗИТИВНЫЕ ИТОГИ
}

\begin{abstract}
В Москве в конце декабря 2017 г. состоялся прием для прессы, посвященный деятельности компании смазочных материалов «ЛУКОЙЛ» в 2017 г. В прошедшем году Компания продемонстрировала рекордный объем продаж готовых масел в премиальном сегменте. По предварительным оценкам, в 2017 г. объем продаж масел ЛУКОЙл современных спецификаций увеличился на 12\% по сравнению с 2016 г.
\end{abstract}

Высокую динамику показали сегменты смазок - рост на $40 \%$ и судовых масел - рост на 23\%. Объем реализации присадок (ЛЛК-НАФТАН) превзошел показатели 2016 г. на 19\%. Компания также существенно упрочила свои позиции на международном рынке. Рост экспортных продаж фирменных масел составил $22 \%$, а реализация продукции зарубежными дочерними обществами выросла на 20\%.
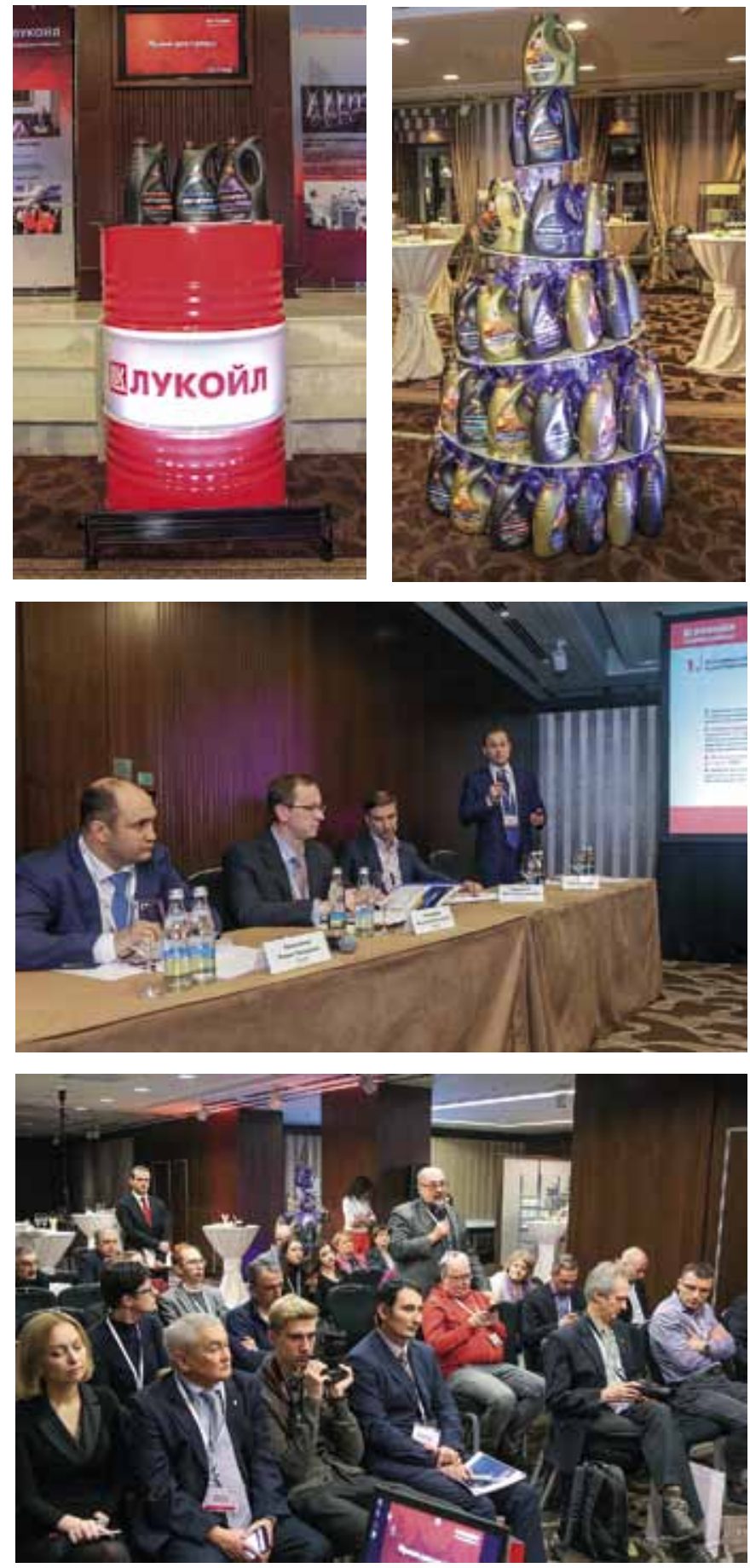

«Успех уходящего года для бизнеса масел ЛУкОЙЛа можно измерить не только в объемных показателях. Зарегистрировав дочерние компании в Мексике и Китае, компания начала прямые продажи на этих крупнейших рынках. Мы приступили к реализации масштабной программы совместных разработок срядом зарубежных производителей, и по итогам аудитов успешно сертифицировали наше производство согласно стандартам ведущих автоконцернов. Все это приблизило нас к участию в глобальных проектах поставок международным автопроизводителям», - отметил генеральный директор ООО «ЛЛК-Интернешнл» (100\% дочернее предприятие ПАО «ЛУКОЙЛ») Максим Дондэ.

\section{ЦИФРЫ И ФАКТЫ}

- 40\% производства смазочных материалов России;

- ежегодный объем производства и продаж - около 1 млн т смазочных материалов;

- производство охватывает семь собственных, два совместных предприятия и 25 привлеченных заводов по всему миру.

Продажи масел ЛУКОЙЛ осуществляются более чем в 100 странах мира. Рост объема продаж фирменных масел ЛУКОЙЛ в 2017 г. достиг 12\%. Ассортимент продукции за 12 лет увеличился в 9 раз (с 80 до 700). Количество одобрений автопроизводителей и производителей промышленного оборудования увеличилось в 40 раз (с 30 в 2006 г. до 1200 в 2017 г.).

Судовые масла ЛУКОЙЛ используются в 950 портах более чем в 100 странах - 12\% мирового рынка.

Стратегическое партнерство с ведущими присадочными компаниями. Собственное, крупнейшее на территории СНГ, производство присадок - ЛЛК-НАФТАН (27 тыс. Т в 2017 г.).

ИНТЕСМО (СП ЛУКОЙЛа и РЖД) - крупнейшее в России производство смазок (около 20 тыс. т ежегодно). Выпускается 115 наименований смазок для различных отраслей

Около 20 действующих контрактов на первую заливку для мировых автопроизводителей: Volkswagen, FordSollers, Renault-Nissan, GM, Chery, Lifan, MAN, MAZ-MAN, МАЗ, ГАЗ, и др.

Предприятия Компании в России, Австрии и Финляндии сертифицированы по главному международному автомобильному стандарту ISO/TS 16949, что подтверждает мировой уровень качества продуктов ЛУКОЙЛ и производственных процессов Компании

Австрийская производственная площадка лУКОЙЛ единственный в Европе завод смазочных материалов, сертифицированный по высшей категории стандарта Ассоциации автомобильной промышленности Германии VDA 6.3, что дает ему статус одного из приоритетных поставщиков масел для немецких автоконцернов. 


\section{0-е судно с начала работы порта погружено на терминале АО «Дальтрансуголь»}

17 января 2018 2. бригада № 1 под руководством сменного диспетчера Александра Пацкова погрузила 71500 m на судно DL Carnation.

Российский уголь, добытый шахтерами Сибирской угольной энергетической компании, отправился потребителям Южной Кореи.

DL Carnation стало 2000-м судном, погруженным с начала деятельности терминала. 1000-й балкер был обработан в порту 11 июня 2014 г.

Бригада № 1 под руководством бригадира Виктора Мартынюка стала лучшей по итогам 2017 года по выгрузке вагонов. В активе бригады 69337 выгруженных вагонов, а также безаварийная работа в течение всего года!

«Бригада дружная, как, впрочем, все наши бригады. Ребята здесь работают сильные, перспективные. Бригадир молодой, но очень инициативный парень, Виктор Мартынюк, бригаду он возглавил недавно, но мы возлагаем на него большие надежды и уверены, он справится. Ежегодно коллектив порта увеличивает количество обрабатываемых судов. В 2016 г. рост составил 4 судна, в 2017 г. - 6», - сказал директор по производству Владимир Франчишин.

В бригаде № 1 работает и самая первая в истории терминала династия докеров Андрей Голядинец и его сын Дмитрий. Вместе с мужем и сыном, в одной смене, работает жена и мама - приемосдатчик Ирина Голядинец.

Дирекция компании поздравила коллектив с юбилейным, 2000-м, судном и пожелала новых трудовых побед и рекордов.
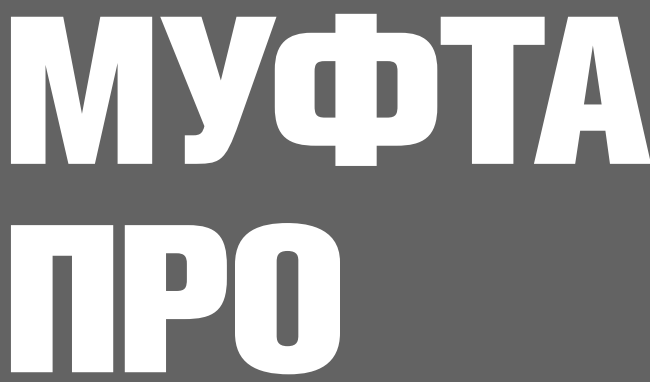

\section{Мы предлагаем:}

- Системы для заправки карьерной техники

- Краны топливозаправочные

- Заправочные клапаны

- Вентиляционные клапаны

- Системы учёта топлива SAMPI S.p.A.

- АЗС, мобильные топливные блоки и автотопливозаправщики со скоростью до 1500 л/ минуту

\section{Контакты:}

О०० «МУФТА ПРО тел.: +7 (499) 3946660 e-mail: muftapro@gmail.com www.muftapro.ru www.muftapro.com

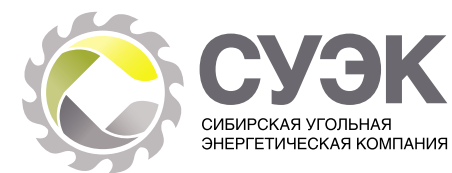

FAST FILL SYSTEMS

WIGGINS
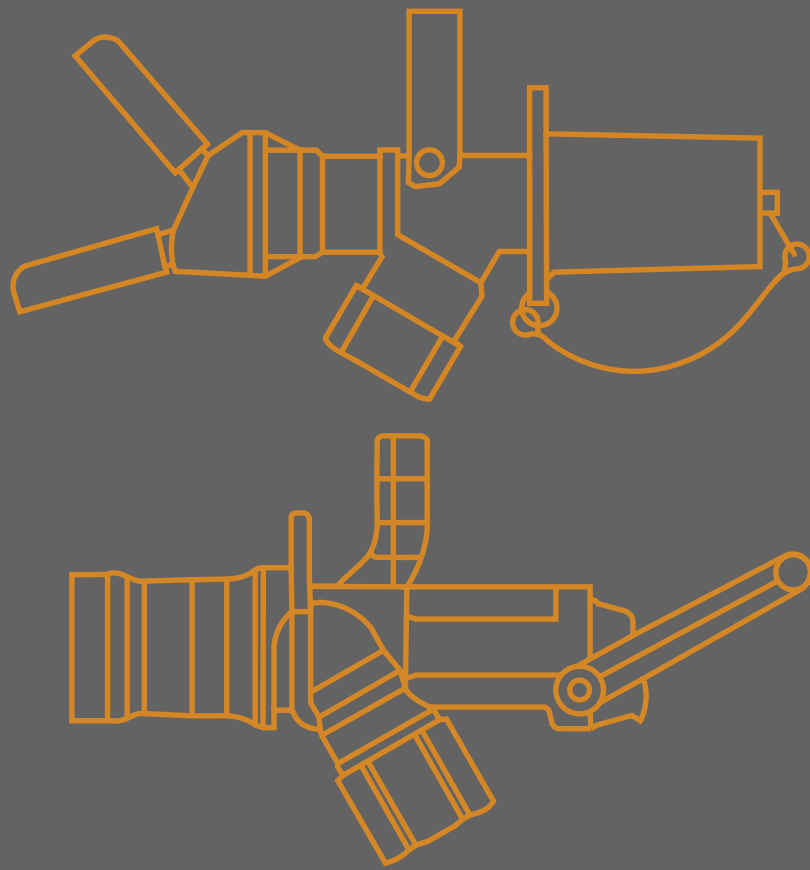

FLOMAX 


\section{Движение к успеху с помощью инноваций}

DOI: http://dx.doi.org/10.18796/0041-5790-2018-2-26-27

\author{
Наталия ШАРШАВЕНКОВА \\ (2. Гомель, Республика Беларусь)
}

Компания ГЕТПАРТ продолжает шагать вверхпо лестнице прогресса, и новой ступенью стало создание Интеллектуальной Системы Управления Автотранспортом - ИСУА. Разработанная в ходе выполнения НИОКР интеллектуальная система управления автотранспортом предназначена для мониторинга работы спецтехники: БелАЗов, экскаваторов, погрузчиков и т.Д. с целью предотвращения возможных аварий, связанных с работой двигателя.

Ключевые слова: ИСУА, ГЕТПАРТ, ЕВРОДИЗЕЛЬ, КаммИнз КТТА 19 и КТА 50, блокуправления двигателем, система мониторинга двигателя.

\section{НОВЫЙ ШАГ НА ПУТИ К РАЗВИТИЮ}

Стремление к прогрессу в развитии собственного бизнеса - рискованный выбор, потому что он требует больших энерго- и временных затрат, но результат всегда непредсказуем: шансы получить многое и многое потерять примерно равны. Без риска невозможно прогрессировать, и технические специалисты компаний ГЕТПАРТ и ЕВРОДИЗЕЛЬ СЕРВИС (ЕДС) знают это не понаслышке. Воспользовавшись своим знанием, они рискнули и сумели добиться положительного результата путем огромного количества потраченных усилий и потраченных не зря.

Компания ГЕТПАРТ продолжает шагать вверх по лестнице прогресса, и новой ступенью стало создание Интеллектуальной Системы Управления Автотранспортом (ИСУА). Специалисты компании понимают, что действительно важно для своих партнеров: их основной ценностью является качество поставляемых запасных частей, которое обеспечит бесперебойную работу технических средств и, как следствие, продуктивную работу предприятий. Но какими надежными ни являлись бы продукты производства WETZ, любые детали рано или поздно подвергаются износу и деформации, и для специалистов выгодно вовремя знать о возможности поломок или факте их происшествия, дабы как можно скорее устранить неполадки и нормализовать работу предприятия. Технические специалисты очень долго готовились к этому шагу, прежде чем смогли его сделать. Слова благодар-
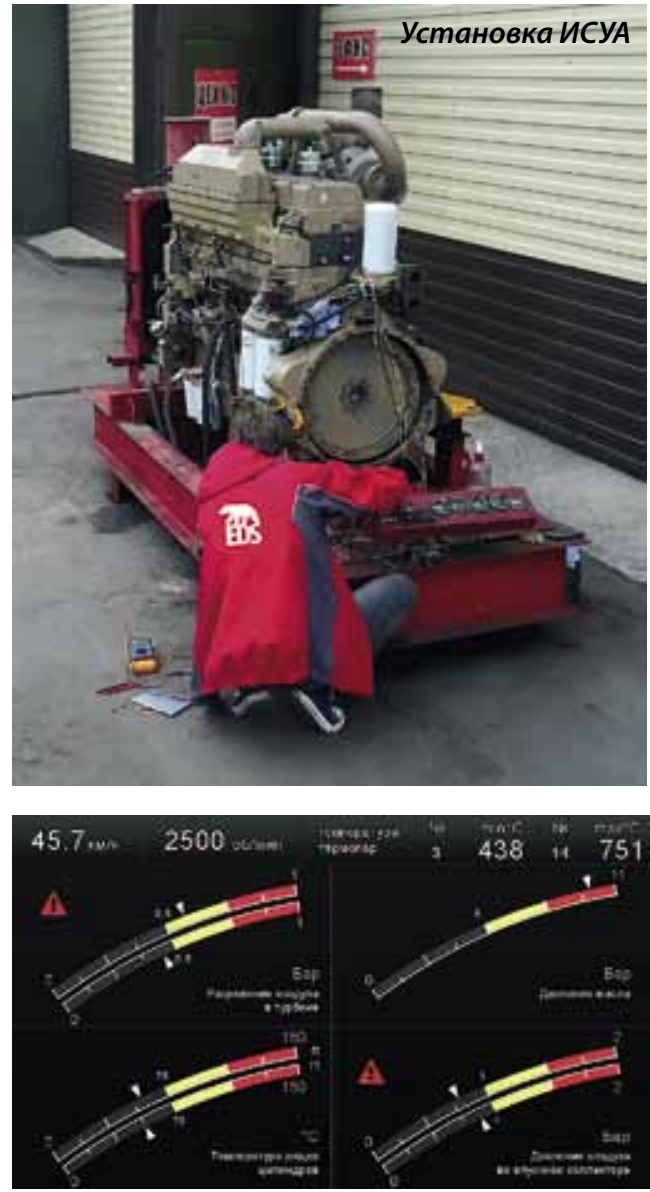

Показания на экране ности можно выразить федеральному Фонду содействия инновациям, который помог в осуществлении этих планов. Компания ГЕТПАРТ получила грант на разработку опытного образца, и деньги, выделенные фондом, были потрачены эффективно: было проведено множество испытаний, доработок, исследований, прежде чем результат удовлетворил создателей, а также технических специалистов, причастных к работе над данным проектом.

Интеллектуальная Система Управления Автотранспортом была представлена на 21-й Международной выставке машин и оборудования для добычи, обогащения и транспортировки полезных ископаемых, которая состоялась весной 2017 г. в г. Москве. ИСУА пользовалась немалой популярностью среди посетителей этого мероприятия. Также ИСУА получила бронзовый диплом в рамках международной выставки «Уголь России и Майнинг», которая проводилась летом 2017 г. в г. Новокузнецке.

\section{ФУНКЦИОНАЛЬНОЕ НАЗНАЧЕНИЕ СИСТЕМЫ}

Разработанная в ходе выполнения НИОКР Интеллектуальная Система Управления Автотранспортом предназначена для мониторинга работы спецтехники: БелАЗов, экскаваторов, погрузчиков и т.д. с целью предотвращения возможных аварий, связанных с работой двигателя. Система способна не только передавать данные в реальном времени, но и оповещать водителя и оператора о возможной неисправности, которая может произойти в ближайшее время, более того, система будет выдавать рекомендации для предотвращения аварии, основываясь на собранных данных с множества датчиков, установленных на двигателе.

В системе заложены тщательно проработанные сценарии, по которым принимается решение о рекомендациях для дальнейшей безопасной эксплуатации техники.

Одной из основных особенностей является возможность установки комплекса контроля с максимальной простотой для потребителя, не требуя особых навыков в установке подобных систем. ИСУА способна максимально точно и подробно отображать состояние автотранспорта, на котором будет установлена, а также обеспечить полный контроль за состоянием агрегатов техники.

Оповещение о нештатных ситуацияхвозможно и при помощи е-mail, CMC, различных мессенджеров. 
В результате исследований было установлено, что на качество эксплуатации двигателя влияет множество факторов, таких как: качество ремонта, качество запчастей и, конечно, человеческий фактор. Как следствие, двигатель мог быстро выходить из строя и влек за собой дорогостоящий ремонт. ИСУА способна предотвращать такие ситуации путем анализа получаемой телеметрии.

На данный момент комплекс успешно работает более чем на 10 предприятиях на различной технике.

\section{АДАПТАЦИЯ СИСТЕМЫ НА БЕЛАЗЕ}

Распространенные на самосвалах БелАЗ двигатели Cummins серии «К» (K19, K38, К50) имеют только стандартный набор датчиков, который не может в полной мере отображать текущее состояние работы ДВС.

Для установки ИСУА на БелАЗе была произведена разработка усовершенствованных, более точных датчиков для передачи цифровых и аналоговых данных. ИСУА может контролировать такие параметры, как:

- обороты двигателя;

- давление масла;

- температура охлаждающей жидкости;

- датчик разреженности воздуха (вакуума) между турбиной и фильтром;

- давление нагнетаемого воздуха;

- высота над уровнем моря;

- температура выхлопных газов с каждого цилиндра;

- многое другое.

\section{ГЛАВНЫЙ ПОМОЩНИК В РАБОТЕ}

По мнению механиков, которым уже удалось поработать с новой системой, ИСУА изменила работу предприятий в лучшую сторону и предотвратила ряд поломок.

По результатам проведенных исследований было установлено, что функционирование ИСУА повысило продуктивность и производительность работы предприятий, при этом уменьшив операционные расходы и решив вопрос нехватки квалифицированных кадров в труднодоступных местах.

Системный блок ИСУА, который иначе называют контроллером, и его защитный короб состоят из трех уровней и представляет собой аналог черного ящика - все данные, полученные системой, будут под самой надежной защитой.

Проводка всей системы и ее защита обладают хорошим уровнем гибкости и высокой термоустойчивостью. Программное обеспечение ИСУА позволяет следить за всеми показателями, обрабатывая их и предоставляя подробную статистику. Прием и передача данных осуществляются через системы GSM, GPS и ГЛОНАСС от контроллера к серверу, обеспечивают надежную связь. В случае если соединение отсутствует, информация может накапливаться в контроллере около месяца, а при возобновлении соединения выгружает ее. Данная функция является залогом сохранения всех данных и обеспечивает надежность работы системы. Через удаленный доступ возможно отслеживать маршрут, определять наиболее трудные места, рассчитывать более выгодную траекторию.

\section{КОНКУРЕНТНЫЕ ПРЕИМУЩЕСТВА}

Интеллектуальная Система Управления Автотранспортом довольно проста в использовании, что позволяет техническим специалистам, работающим с данной системой, не тратить большое количество времени и сил на установку и сра-

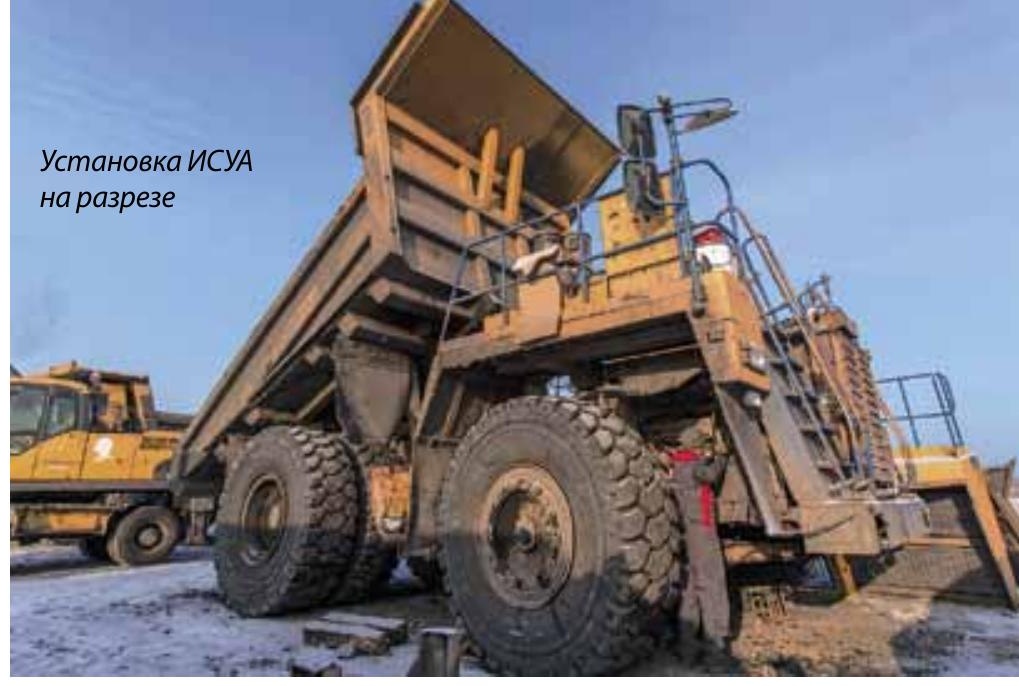

зу же после приобретения данной системы иметь возможность приступить к ее установке и непосредственному использованию.

Монтаж датчиков на двигателе и прокладка всей необходимой проводки производятся в цехе или любом другом закрытом помещении. Двигатель должен быть полностью собран, исправен и пройти предварительную обкатку. Время монтажа занимает от 1 ч до 1 дня в зависимости от типа двигателя, количества датчиков и сложности. Далее двигатель отдается заказчику на установку в машину. После его монтажа в машине и подключения ко всем узлам проводится окончательное подключение - монтаж блока управления, антенн, дисплея. Время установки составляет от 1 до 3 ч в зависимости от сложности прокладки проводки. Специалисты компаний ГЕТПАРТ и ЕДС готовы обеспечить высокий уровень сервисной поддержки на протяжении всего срока службы ИСУА.

Разработка и инжиниринг - компания ГЕТПАРТ: тел.: +7 (3842) 452-469 (2. Кемерово).

Сервис и обслуживание - компания ЕДС: тел.: +7 (3843) 734-088 (2. Новокузнецк)

TRANSPORT

UDC 622.684.004.67:656.13 @ N.A. Sharshavenkova, 2018 ISSN 0041-5790 (Print) • ISSN 2412-8333 (Online) • Ugol' - Russian Coal Journal, 2018, № 2, pp. 26-27

\section{Title}

\section{REACHING SUCCESS THROUGH INNOVATIONS}

DOI: http://dx.doi.org/10.18796/0041-5790-2018-2-26-27

\section{Author}

Sharshavenkova N.A. ${ }^{1}$

${ }^{1}$ Gomel, 246001, Republic of Belarus

\section{Authors' Information}

Sharshavenkova N.A., Journalist, Independent Correspondent

\section{Abstract}

The company GETPART continues ascending the ladder of progress, creation of the Intelligent Vehicle Management System - ISUA being a new step. The intelligent vehicle management system, developed during $R \& D$, is designed to monitor the operation of special equipment: BelAZ trucks, excavators, loaders, etc. in order to prevent possible accidents, associated with motor operation.

\section{Keywords}

ISUA, GETPART, EURODIESEL, Cummins KTTA19 and KTA 50, Motor control module, Motor monitoring system 


\section{Нагнетание воды в пласт антрацита повышенного давления через скважины направленного бурения благоприятствует экономике и экологии}

DOI: http://dx.doi.org/10.18796/0041-5790-2018-2-28-31

В статье представлены сведения о запасах антрацитовыхуглей в Восточном Донбассе, качественные показатели после их обогащения. Приводятся коэффициенты крепости пластов антрацита по шкале проф. М.М. Протодьяконова, рост цен на его сорта. Излагаются способы снижения крепости пластов антрацита, что вызовет увеличение выхода его сортов при обогащении, повысит производительность струговых комплексов и горнопроходческих комбайнов. Нагнетание воды в пласт антрацита повышенного давления вызовет кислотно-восстановительную реакцию находящихся в угле ангидридов и оксидов, образуя в конечном итоге соли, предупреждая выбросы токсичных веществ в атмосферу, чем снизит негативные последствия экологии на флору и фауну.

Ключевые слова: нагнетание воды, повышенное давление, скважины направленного бурения, экология, сорта антрачита, зола, сера, влага, струговый комплекс, ангидрид, нанотехнология, мельчайшие частицы, кислотно-восстановительная реакция, физический прочесс.

\section{ВВЕДЕНИЕ}

Основные запасы антрацитовых углей в европейской части России находятся в Восточном Донбассе. Разведанные запасы составляют 6 млрд т, прогнозных насчитывается еще 6 млрд т. Из числа оставшихся шахт после проведенной реорганизации угольной промышленности наиболее значимой считается шахта «Обуховская» с проектной мощностью 3 млн т в год, отрабатывающая пласт $\mathrm{K}_{2}$ с коэффициентом крепости по М.М. Протодья- конову $f=2-2,5$ и с получением сортов антрацита после обогащения, представленных в табл. 1.

На шахте «Садкинская» разрабатывают самый крепкий из всех пластов антрацита - $m_{8}^{1}$ с коэффициентом крепости по М.М. Протодьяконову $f=2,5-3$. При такой крепости антрацита становится неприемлемым использование для его выемки струговых комплексов. Для выемки такого угля в лавах всех оставшихся антрацитовых шахт применяют только очистные комбайны, которые сильно измельчают антрацит. После его обогащения на выходе все шахты имеют примерно, как и на шахте «Садкинская», равные итоги:штыба - 40\%, семечки - $13 \%$, мелкого - $12 \%$, ореха - $10 \%$, кулака - до $1 \%$.

В прошлом, еще в Краснодонецком шахтоуправлении, когда в лавах работали врубовые машины, из этого же пласта $m_{8}^{1}$ выходило 52\% самых крупных сортов, кулака и плиты. При селективной выемке пласта уголь и прослой добывались отдельно, таких сортов было 70\%. В то же время, например, шахта «Юбилейная» в Ростовской области добывала антрацит только струговыми комплексами и имела на выход штыба всего 15\%, а остальные, средние и крупные сорта, не имея своей обогатительной фабрики, вынуждена была транспортировать на соседнюю шахту «Аютинская» с обогатительной фабрикой и терять еще больше штыба на $2 \%$, т.е. $17 \%$.

Если удастся добывать на шахтах «Садкинская» и «Обуховская» с проектной мощностью каждой по 3 млн т в год уголь струговыми комплексами, то дополнительная выручка составит 1,5 млрд руб. в год по каждой шахте. Ана-

Таблича 1

\section{Сорта антрацита шахты «Обуховская» после обогащения}

\begin{tabular}{|l|c|c|c|c|c|}
\hline \multicolumn{1}{|c|}{ Сорт } & Размеры, мм & Зола, \% & Сера, \% & Влага, \% & Теплотворность, ккал/K \\
\hline Штыб & $0-6$ & 14 & 0,9 & 11 & 5000 \\
\hline Семечка & $6-13$ & 7,5 & 0,9 & 5 & 6500 \\
\hline Мелкий & $13-25$ & 6,5 & 0,9 & 4 & 6500 \\
\hline Орех & $27-70$ & 4,5 & 0,9 & 4 & 7000 \\
\hline Кулак & $75-120$ & 4,0 & 0,9 & 4 & 7500 \\
\hline Прита & $>120$ & 4,0 & 0,9 & 4 & 7700 \\
\hline
\end{tabular}


логичная выручка будет получена и на других антрацитовых шахтах, если удастся добывать уголь струговыми комплексами. Кроме того, за последний год цена на сортовой антрацит выросла в два и более раз.

Сегодня экономика антрацитовых шахт имеет для роста две составляющие: увеличение выручки за счет увеличения средних и крупных сортов при одновременном сокращении выхода штыба при внедрении струговых комплексов по новой технологии добычи угля и уверенный рост цен на сортовой антрацит.

\section{СПОСОБ ПОЛУЧЕНИЯ \\ СРЕДНИХ И КРУПНЫХ СОРТОВ АНТРАЦИТА \\ В УСЛОВИЯХ ЕГО ПОВЫШЕННОЙ КРЕПОСТИ, \\ ГДЕ ОБЫЧНЫЕ СТРУГОВЫЕ КОМПЛЕКСЫ \\ ДЛЯ ЭТИХ ЦЕЛЕЙ СЧИТАЛИСЬ НЕПРИЕМЛЕМЫМИ \\ (Заявка на изобретение № 2017108555. \\ Автор М.В. Попов)}

В 1963 г. в шахтоуправлении «Краснодонецкое» комбината «Ростовуголь», разрабатывавшем высокогазоносный пласт $m_{8}^{1}$ (мощностью 0,95-1,65 м, относительная газообильность 106,5 м³/т), при бурении двух разведочных скважин на воду было замечено обильное газовыделение из них: одна из скважин была направлена по восстанию пласта, а вторая - близко к простиранию. Особенно интенсивно газ выделялся из последней скважины, расположенной поперек кливажных трещин.

Как установлено в дальнейшем из анализа, из скважин, пробуренных по простиранию пласта, поперек кливажных трещин, газа выделилось в десятки раз больше, чем из скважин, пробуренных по восстанию пласта, вдоль кливажных трещин. Количество выделяемого газа из скважин определялось при свободном его истечении газосчетчиком ГКФ.

С учетом достигнутого положительного результата в шахтоуправлении «Краснодонецкое» абсолютное газовыделение рабочего пласта уменьшилось на 44-50\%. Была принята и внедрена схема бурения скважин для дегазации рабочего пласта, что позволило увеличить нагрузку на лаву, улучшить технико-экономические показатели и обеспечить безопасные условия работы.

К сожалению, буровые станки 1960-х гг. не обладали производительным и направленным бурением, были громоздкими, способными бурить с нескольких попыток до 100 м. В связи с этим дальнейшее развитие дегазации неразгруженного пласта было приостановлено. В результате полученного опыта было установлено, что пласт $m_{8}^{1}$ обладает наибольшей проницательной способностью вдоль кливажа, как для воздуха, так и для воды и, наоборот, с наименьшей - поперек кливажу [1, 2].

В Краснодонецком шахтоуправлении, отрабатывающем пласт $m_{8}^{1}$ с относительной газообильностью 106,5 м $3 /$ т, возникла необходимость в проведении навстречу проходимому сверху вниз по углю (с подрывкой породы) фланговому шурфу № 1 большой протяженности сбойки под углом $14^{\circ}$. Но буровзрывной способ на сверхкатегорной шахте по метану при проведении выработок, тем более по углю (снизу вверх), по условиям безопасности недопустим, да и сам пласт антрацита с коэффициентом крепости угля по М.М. Протодьяконову $f=2,5-3$ не мог быть отработан с использованием других известных способов выемки угля в таких условиях.

Невозможно было применять в лавах для выемки угля и струговые комплексы, так как рабочий орган струга не мог скалывать уголь такой крепости. В результате было принято решение, в которое мало кто верил, - проходить выработку с выемкой угля отбойными молотками после предварительного опережающего увлажнения пласта повышенным давлением. В центре выработки параметрами 2×1,4 м бурили шпур глубиной 2,5 м и нагнетали воду в пласт (по качественным показателям близка к питьевой) под давлением 11 МПа (110 атм.) в течение 1-1,1 ч до тех пор, пока давление не начинало резко падать. При нагнетании воды в пласт слышался множественный треск разной громкости, сопровождаемый периодическими глухими ударами. После окончания нагнетания воды в пласт двое рабочих очистного забоя производили выемку угля отбойными молотками с подвиганием забоя на 2 м до конца смены.

После окончания выемки угля периодически из забоя бурили шпуры в бока выработки для определения ширины зоны увлажнения, которая составляла 1-1,2 м. При переходе в неувлажненный антрацит сопротивление бурению резко возрастало, заметно увеличивалось выделение метана из пробуренного шпура. Установлено, что зона увлажнения поперек кливажу достигала 4-4,5 м. Из всех операций, выполняемых рабочими в смене, на выемку угля оставалось не более 3 ч при шестичасовом рабочем дне. В сутки четыре смены по 6 ч проходили 8 м выработки по углю отбойными молотками, а за месяц до сбойки 182 м. Эксперимент удался. Главным критерием, определившим успех, было то, что при нагнетании воды с давлением 11 МПа в течение 1-1,1 ч антрацит потерял крепость до минимума, что позволило успешно производить его выемку отбойными молотками.

Итак, в результате практических работ было установлено, что пласт $m_{8}^{1}$ подвержен природной трещиноватости с кливажом, направление расположения которого - по восстанию-падению, как в границах шахтного поля Краснодонецкого шахтоуправления, так и в границах шахты «Садкинская». В результате направленных скважин, пробуренных для спуска воды и дегазации пласта $m_{8}^{1}$, обнаружено, что он значительно проницаем как для газа, так и воды вдоль кливажных трещин и, наоборот, почти непроницаем поперек кливажным трещинам. На этом природном явлении и была проведена дегазация рабочего пласта двух лав при свободном истечении метана в течение года [3].

Известно, что наибольший выход сортов антрацитового угля происходит при выемке его в лавах струговыми комплексами. Чтобы создать благоприятные условия для работы высокопроизводительных комплексов на антрацитовых пластах с ярко выраженным кливажом и другими трещинами, параллельными ему, и повышенным содержанием крепких углей, подготовку выемочных столбов следует располагать так, чтобы рабочий орган стругал забой лавы вдоль кливажных трещин, снимая каждую последующую стружку угля, внедряясь с наименьшим усилием в трещины кливажа и скалывая ее.

Наибольший эффект при предварительном нагнетании воды произойдет при поперечном расположении скважин к кливажу, ибо согласуется с предлагаемой подготов- 
кой лав, располагая скважины на таком удалении друг от друга, чтобы образовалась единая зона надежного увлажнения со значительным снижением крепости антрацита. В настоящее время это возможно. Как показала международная практика в Австралии, современные буровые установки направленного бурения могут бурить на расстояние до 2 км, а за смену - 500 м. У нас в России сегодня есть такие установки, например на шахте им. Кирова и других шахтах Кузбасса.

\section{СПОСОБ ПРОВЕДЕНИЯ ГОРНЫХ ВЫРАБОТОК ПО ПЛАСТУ УГЛЯ С ПОВЫШЕННОЙ КРЕПОСТЬЮ И ПОДРЫВКОЙ БОКОВЫХ ПОРОД}

\section{(Заявка на изобретение № 2017120706.}

\section{Автор М.B. Попов)}

Основываясь на достигнутом практическом опыте, в целях снижения крепости угля и сопротивления его скалыванию-резанию по углю при проведении горных выработок горнопроходческими комбайнами и другими видами машин и механизмов, из забоя выработки по углю бурят скважины по направлению движения выработок длиной не менее 1 м цикла подвигания выработки или на всю длину ее прохождения при программном направленном бурении скважины. Производят нагнетание воды в пласт с замерами давления воды, количества ее расхода, времени нагнетания; проходят выработки на величины циклов увлажненного пласта или на полную их длину, если пласт увлажнен на всю длину проведения.

Для выбора параметров выработок в зависимости от ширины увлажненного угля со снижением его крепости и сопротивлением резания-скалывания, которая может быть разной в зависимости от кливажа угля и его трещиноватости, периодически, через каждые 5-10 м в бока выработки бурят шпуры по увлажненному углю до начала сопротивления его из-за крепости. Увлажненный уголь значительно снижает запыленность при выемке, транспортировке и переработке, что улучшает санитарно-гигиенические условия труда.

В свете изложенных практических результатов снижения крепости антрацита путем нагнетания воды в пласт предлагаются два способа проходки горных выработок по пластам с повышенной крепостью.

1-й способ. Цикличный способ проходки выработки через пробуренные шпуры с увлажнением и снижением крепости угля на ширину проводимой выработки с последующей выемкой угля горнопроходческими комбайнами или другими способами до целика неувлажненного угля с выраженным кливажом. Периодически в бока выработки бурятся шпуры для определения зоны увлажнения пласта. Цикл может замыкаться в течение нескольких часов, смены, суток.

2-й способ. Поточный способ проходки выработок. Скважина бурится современной буровой установкой по углю на всю длину выработки с последующим нагнетанием воды в нее с увлажнением пласта и снижением крепости его на ширину не менее ширины проводимой выработки с последующей выемкой угля горнопроходческими комбайнами или другими способами и выполнением видов работ, предусмотренных паспортом или проектом. Вначале через каждые 5-10 м в бока выработки бурят шпуры, опре- деляя площадь увлажнения угля. При нагнетании воды в пласт производятся замеры ее давления, количества, расхода, времени ее нагнетания. Расположение кливажа в целике угля влияет на ширину увлажнения, количество расходуемой воды и времени нагнетания соответственно.

\section{РЕШЕНИЕ ЭКОЛОГИЧЕСКИХ, \\ САНИТАРНО-ГИГИЕНИЧЕСКИХ \\ И ЭКОНОМИЧЕСКИХ ВОПРОСОВ}

В результате исследований Новосибирского научноисследовательского института установлено, что в составе золы в антрацитовых углях шахты «Садкинская» Ростовской области содержатся элементы, представленные в табл. 2.

Таблица 2

\begin{tabular}{|c|c|}
\hline Элементы & Содержание, \% \\
\hline $\mathrm{SiO}_{2}$ & 53,3 \\
\hline $\mathrm{A}_{2} \mathrm{O}_{3}$ & 28,9 \\
\hline $\mathrm{Fe}_{2} \mathrm{O}_{3}$ & 7,8 \\
\hline $\mathrm{CaO}$ & 0,78 \\
\hline $\mathrm{MgO}$ & 1,20 \\
\hline $\mathrm{Na}_{2} \mathrm{O}$ & 1,03 \\
\hline $\mathrm{K}_{2} \mathrm{O}$ & 5,25 \\
\hline $\mathrm{MnO}_{2}$ & 0,02 \\
\hline $\mathrm{TiO}_{2}$ & 0,90 \\
\hline $\mathrm{P}_{2} \mathrm{O}_{3}$ & 0,07 \\
\hline $\mathrm{SO}_{3}$ & 0,50 \\
\hline Others (прочие) & 0,25 \\
\hline Bcero & 100 \\
\hline
\end{tabular}

При нагнетании воды в пласт происходят физические процессы и химические реакции. Под большим давлением водой разрушаются связи в угле, значительно снижается его крепость с вероятным образованием макро-, микро- и наночастиц.

На основании последних исследований в области нанотехнологий доказано, что нейтральные твердые вещества (в данном случае антрацит) при разрушении до мельчайших частиц в сочетании со средой (в данном случае с водой) приобретают новые свойства и вступают в химические реакции с веществами, присутствующими в угле [4].

При соединении с водой агидрид серы образует серную кислоту $\mathrm{SO}_{3}+\mathrm{H}_{2} \mathrm{O}=\mathrm{H}_{2} \mathrm{SO}_{4}$ [5].

Наличие шумовых эффектов при нагнетании воды в пласт угля свидетельствует об активных окислительновосстановительных реакциях, образуя кислоты, которые, соединяясь с оксидами других веществ (см. табл. 2), превращают их в соли, тем самым способствуют ликвидации выбросов их в атмосферу, пройдя через ТЭС, предотвращают негативные воздействия на флору и фауну.

В результате нагнетания воды под повышенным давлением в пласт угля происходит значительное увлажнение его, тем самым значительно снижается уровень пыли, улучшаются санитарно-технические условия, связанные с добычей и переработкой угля. Снижение измельчен- 
ности антрацита при струговой выемке вместо комбайновой способствует и снижению уровня его запыленности. В состав золы (см. табл. 2) входят до $30 \% \mathrm{~A}_{2} \mathrm{O}_{3}$ и ряд других оксидов. Это значит, что при ее нагреве можно будет получить ряд элементов и изделий облегченной конструкции для строительства, а также вещества из области углехимии.

\section{ЗАКЛЮЧЕНИЕ}

В результате нагнетания воды с повышенным давлением в антрацитовый пласт с выраженной трещиноватостью, образованной в основном природным кливажем, значительно снижается крепость угля и, соответственно, сопротивление скалыванию-резанию, и предоставляется возможность применить для выемки угля высокопроизводительные струговые комплексы с рабочим органом и резцами, производящими резание-скалывание вдоль кливажных трещин.

Значительно увеличивается после обогащения выход ценных средних и крупных сортов антрацита, существенно решается экономическая целесообразность эксплуатации антрацитовых шахт.

Существенно повышается производительность проходческих комбайнов при проведении горных выработок преимущественно по крепким антрацитовым пластам, тем самым увеличиваются темпы проведения этих выработок и удешевляется их себестоимость.

Вода при нагнетании с повышенным давлением в антрацитовые пласты обладает реакционным свойством, сое- диняясь со многими оксидами металлов и неметаллов, ангидридами, расположенными преимущественно в трещинах и микротрещинах кливажа, вызывает бурную реакцию с образованиями оснований и кислот, переходящих в соли, предупреждая после сжигания угля на ТЭЦ выброс в атмосферу, тем самым не загрязняется атмосфера токсичными веществами.

Из-за снижения измельченности антрацита в результате перехода с комбайновой на струговую выемку и увлажнения угля в целике значительно снижается уровень запыленности.

\section{Список литературы}

1. Попов М.В. Способ дегазации неразгруженных угольных пластов // Безопасность труда в промышленности. 1969. № 4.

2. Патент на изобретение № 2442899 «Способ дегазации неразгруженных угольных пластов». Патентообладатели: Попов М.В., Попов Е.М. Приоритет изобретения 25 июня 2010 г.

3. Патент на изобретение № 2466277 «Способы проведения горных выработок в шахтах, опасных по газу метану». Патентообладатели: Попов М.В., Попов Е.М. Приоритет изобретения 15 октября 2010 г.

4. Попов М.В., Попов Е.М. Нанотехнологии, реальна ли их опасность // Безопасность труда в промышленности. 2010. № 4.

5. Глинка Н.Л. Общая химия. М.: Интеграл-пресс, 2008. С. 463.

UNDERGROUND MINING

UDC 622.272:622.335:622.233.016.25:539.217.3 @ M.V. Popov, 2018

ISSN 0041-5790 (Print) • ISSN 2412-8333 (Online) • Ugol' - Russian Coal Journal, 2018, № 2, pp. 28-31

Title

WATER INJECTION IN HIGH PRESSURE ANTHRACITE STRATUM THROUGH DIRECTIONAL DRILLING BOREHOLES IS BENEFICIAL FOR ECONOMICS AND ENVIRONMENT

DOI: http://dx.doi.org/10.18796/0041-5790-2018-2-28-31

Author

Popov M.V. ${ }^{1}$

${ }^{1}$ Shahty, 346503, Russian Federation

Authors' Information

Popov M.V., PhD (Engineering), Mining Engineer, tel.: +7-960-46-46-591

\section{Abstract}

The paper presents data on anthracite coal reserves in the Eastern Donbass and post beneficiation quality indicators. Anthracite strata Protodyakonov hardness index with respective coal grades price escalation are also indicated. Methods of anthracite strata hardness reduction are presented, thus causing anthracite grades recovery improvement during beneficiation with plough complex and heading machines efficiency increase. Water injection in high pressure anthracite stratum will launch oxidation-reduction reaction of coal contained anhydrides and oxides, ultimately generating salts and preventing emission of toxic substances to atmosphere, thus minimizing negative environmental impact for flora and fauna.

\section{Keywords}

Water injection, High pressure, Directional drilling boreholes, Environment Anthracite grades, Ash, Sulphur, Moisture, Plough complex, Anhydride, Nanotechnology, Fine particles, Oxidation-reduction reaction, Physical process.

\section{References}

1. Popov M.V. Sposob degazatsii nerazgruzhennyh ugolnyh plastov [Unrelieved coal strata gas drainage]. Bezopasnost truda v promyshlennosti - Industrial Labor safety, 1969, No. 4.

2. Invention patent No. 2442899"Sposob degazatsii nerazgruzhennyh ugolnyh plastov" [Unrelieved coal strata gas drainage]. Patent holders: Popov M.V., Popov E.M. Invention priority 25 June 2010.

3. Invention patent No. 2466277 "Sposoby provedeniya gornyh vyrabotok v shahtah opasnyh po gazu metanu" [Methods of methane hazardous mines workings]. Patent holders: Popov M.V., Popov E.M. Invention priority 15 October 2010.

4. Popov M.V., Popov E.M. Nanotekhnologii realna li ih opasnost [Nanotechnologies, if their danger is real]. Bezopasnost truda $v$ promyshlennosti Industrial Labor safety, 2010, No. 4.

5. Glinka N.L. Obshchaya himiya [General chemistry]. Moscow, Integral-press Publ., 2008, p. 463. 


\section{Обоснование геометрических и режимных параметров шнековых исполнительных органов, обеспечивающих эффективность погрузки угля на забойный конвейер}

DOI: http://dx.doi.org/10.18796/0041-5790-2018-2-32-35

\section{ГАБОВ Виктор Васильевич}

Доктор техн. наук, профессор кафедры Машиностроения ФГБОУВО «Санкт-Петербургский горный университет», 199106, г. Санкт-Петербург, Россия

\section{НГУЕН Кхак Линь}

Аспирант кафедры Машиностроения

ФГБОУВО «Санкт-Петербургский горный университет», 199106, г. Санкт-Петербург, Россия,

e-mail:khaclinhhumg@gmail.com

\section{НГУЕН Ван Суан}

Аспирант кафедры Машиностроения,

ФГБОУВО «Санкт-Петербургский горныйуниверситет», 199106, г. Санкт-Петербург, Россия

\section{ЛЕ Тхань Бинь}

Аспирант кафедры Машиностроения

ФГБОУ ВО «Санкт-Петербургский горный университет», 199106, г. Санкт-Петербург, Россия

\section{ЗАДКОВ Денис Александрович,}

Канд. техн. наук,

дочент кафедры Машиностроения

ФГБОУВО «Санкт-Петербургский горный университет», 199106, г. Санкт-Петербург, Россия

Анализируются процессы выгрузки угля из зоны разрушения и погрузки его на забойный конвейер шнековыми исполнительными органами очистных комбайнов в комплексно-механизированных очистных забоях угольных шахт. Рассмотрены возможности повышения эффективности погрузки угля на забойный конвейер по критериям снижения дополнительного измельчения угля и удельного расхода энергии, что достигается увеличением площади сечения погрузочного окна и объема зоны погрузки на конвейере.

Ключевые слова: подземная добыча угля, комплексномеханизированный очистной забой, комбайн, шнековый исполнительный орган, забойный конвейер, уголь, погрузка, измельчение, эффективность.

\section{ВВЕДЕНИЕ}

Шнековый исполнительный орган очистного комбайна в очистных механизированных комплектах (ОМК) выполняет основную функцию - отделение угля от массива и погрузку его на забойный конвейер. Шнековые исполнительные органы отличаются технологичностью работы, компактностью, простотой конструкции, надежностью и долговечностью $[1,2,3]$. Однако отстающим по ходу движения комбайна шнековым исполнительным органам свойственна неудовлетворительная зачистка почвы, которая приводит к снижению производительности комбайна, повышению удельного расхода энергии и к дополнительному измельчению угля при погрузке его на конвейер. Основными причинами такого положения являются ограниченные размеры погрузочного окна и большое расстояние между шнеком и конвейером $[1,4,5]$. Проблема заключается в том, что нет технических решений и апробированных методик определения структуры и параметров шнековых исполнительных органов очистных комбайнов, их вписываемости совместно с конвейером и погрузочными щитами в пространство забоя с требуемыми значениями показателей эффективности процесса погрузки отбитого угля на забойный конвейер.

\section{ОБОСНОВАНИЕ ПАРАМЕТРОВ ШНЕКОВЫХ ИСПОЛНИТЕЛЬНЫХ ОРГАНОВ ОЧИСТНЫХ КОМБАЙНОВ}

Исследование процесса погрузки и обоснование параметров шнековых исполнительных органов очистных комбайнов, обеспечивающих повышение эффективности погрузочно-транспортирующего процесса, являются актуальной научной задачей.

Перемещение сыпучего материала в горизонтальных и слабонаклонных шнековых погрузочных и транспортирующих механизмах с относительно небольшим коэффициентом заполнения рабочего пространства (до 0,3-0,4) сопровождается формированием перед каждой лопастью тела волочения. Внутри тела волочения происходят циркуляционные процессы, вызванные разнонаправленными силами тяжести, инерции и трения $[6,7]$. Этим обусловлен основной недостаток шнековых транспортеров - повышенные энергозатраты на перемещение материала и его дополнительное, вторичное (часто нежелательное) измельчение. Интенсивность циркуляции транспортируемого материала в объеме тела волочения резко возрас- 


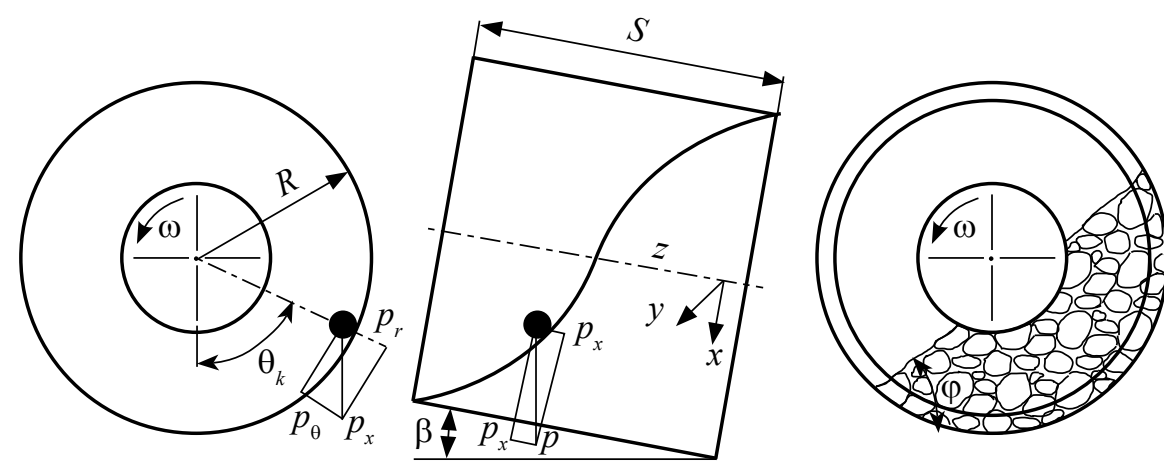

Puc. 1. Массы перемещения в шнеке

Fig. 1. Screw conveyor mass haul

тает при достижении некоторого критического угла отклонения $\theta_{\kappa}$ тела волочения (рис. 1) в направлении вращения шнека, при котором создаются условия для осыпания материала по линии наименьшего сопротивления на его свободной поверхности.

Угол отклонения материала может быть определен по выражению [6]:

$\theta_{\kappa}=\arcsin \left(\frac{\operatorname{tg} \beta+\frac{f_{2} R \omega^{2}}{g \cos \beta}}{\sqrt{\left[\frac{2 \pi R}{S}\left(1-f_{1} \sqrt{\operatorname{ctg}^{2} \gamma+\left(\frac{S}{2 \pi R}\right)^{2}+1}+f_{2} \operatorname{ctg} \gamma\right)+f_{2}^{2}\right]}}\right)+$

$+\operatorname{arctg} \frac{f_{2}}{\frac{2 \pi R}{S}\left(1-f_{1} \sqrt{\operatorname{ctg}^{2} \gamma+\left(\frac{S}{2 \pi R}\right)^{2}+1}+f_{2} \operatorname{ctg} \gamma\right)}$,

где: $\gamma$ - угол наклона оси шнека к горизонтальной плоскости; $\beta$-угол наклона оси шнека к горизонтальной плоскости; $R$ - радиус направляющей поверхности, м; $S$ - шаг винтовой линии шнека, м; $f_{1}$ - коэффициент трения материала по ограничивающей поток поверхности (поверхности забоя, подпорного щитка, направляющей трубы, скважины); $f_{2}$ - коэффициент трения движения материала по лопасти; $\omega$ - частота вращения шнека, 1 сс; $g$-ускорение свободного падения, $\mathrm{m} / \mathrm{c}^{2}$.

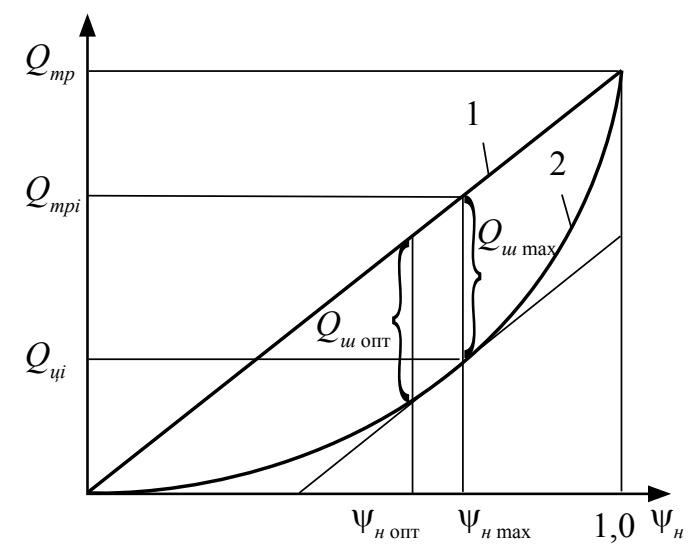

Рис. 2. Зависимость производительности шнекового исполнительного органа по отбитому $Q_{m p}$ и ииркулирующему углю $Q_{u}$ в функции коэффициента заполнения сечения шнека [1]

Fig. 2. Screw operating device broken-down coal $Q_{m p}$ and circulating coal $Q_{u}$ ratio in the screw conveyor section filling index function [1]
Степень и характер влияния геометрических и режимных параметров шнека и свойств транспортируемого материала на величину $\theta_{K}$ представлены в исследованиях М.С. Сафохина, И.М. Питбаума, В.Н. Вернера и др. [5, 6, 8]. Учитывая приведенные зависимости, можно судить об эквивалентности влияния различных факторов на угол отклонения движения материала в шнеке по линиям идентичных режимов. Чем больше угол отклонения материала $\theta_{K^{\prime}}$ тем выше интенсивность циркуляции $k_{u}$.

Заполнение сечения шнека зависит от разности диаметров шнека и его ступицы. Как указано в работах [1, 6], увеличение заполнения шнека приводит к росту коэффициента циркуляции. Значения коэффициента заполнения $\psi_{н}$ и интенсивности циркуляции $k_{u}$ существенно зависят от скорости подачи комбайна и диаметра шнека. Кроме того, интенсивность циркуляции зависит от метательной способности шнека, которая возрастает с ростом угла подъема винтовой линии, так как составляющие усилий $p_{r}$ и $p_{\theta}$ (см. рис. 1), перебрасывающих материал, возрастают с ростом угла подъема винтовой линии $\alpha_{i}$. Кривая имеет минимум при значениях $\alpha_{i}=18-23^{\circ}[1]$.

Интенсивность циркуляции материала в процессе погрузки можно оценить коэффициентом циркуляции $k_{u}$ для любого значения коэффициента заполнения $\psi_{н}$ :

$$
k_{u}=\frac{Q_{u}}{Q_{m p}-Q_{u}},
$$

где: $Q_{m p}$ - производительность шнекового исполнительного органа по отбойке; $Q_{u}$ - производительность шнека по циркулирующему материалу (рис. 2).

Линия 1 (см. рис. 2) характеризует зависимость производительности шнека по отбитому углю, а линия 2 - объем угля по циркулирующему материалу. Значение $\psi_{н \max }$ определяет величину коэффициента заполнения, превышение которым критического значения приводит к возрастанию объема циркулирующего материала.

В зависимости от направления вращения отстающего шнекового исполнительного органа очистных комбайнов отбитый материал располагается внутри шнекового пространства определенным образом (рис. 3).

При попутном вращении шнека (от почвы к кровле) по отношению к скорости подачи комбайна (cм. puc. 3, a) основная масса отбитого угля падает вниз и подается шнеком на забойный конвейер, оставаясь в призабойном рабочем пространстве. В этом случае измельчение угля снижается.

Угол $\varphi$ (см. рис. 3.) зависит от коэффициента трения угля о поверхность лопастей шнека и ступицы и пропорционален отклонению угла в положении материала $\theta_{\kappa}$. $\mathrm{C}$ ростом производительности шнека уровень его наполнения на выходе увеличивается (см. рис. 3, положения I, II).

При встречном вращении шнека (от кровли к почве), по отношению к скорости подачи (см. рис. 2, 6), основная масса погружаемого угля располагается со стороны погрузочного щита, образуя угол $\varphi$ с почвой пласта. По мере увеличения скорости подачи комбайна поток угля в шнеке уве- 

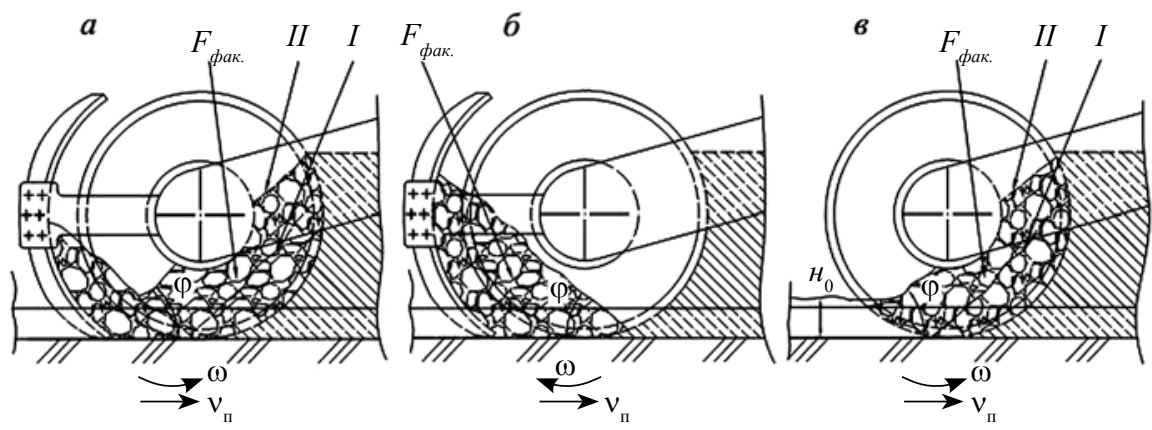

Puс. 3. Схемы расположения отбитого угля в рабочем пространстве отстающего шнека

Fig. 3. Diagrams of broken-down coal layout in the second advance screw
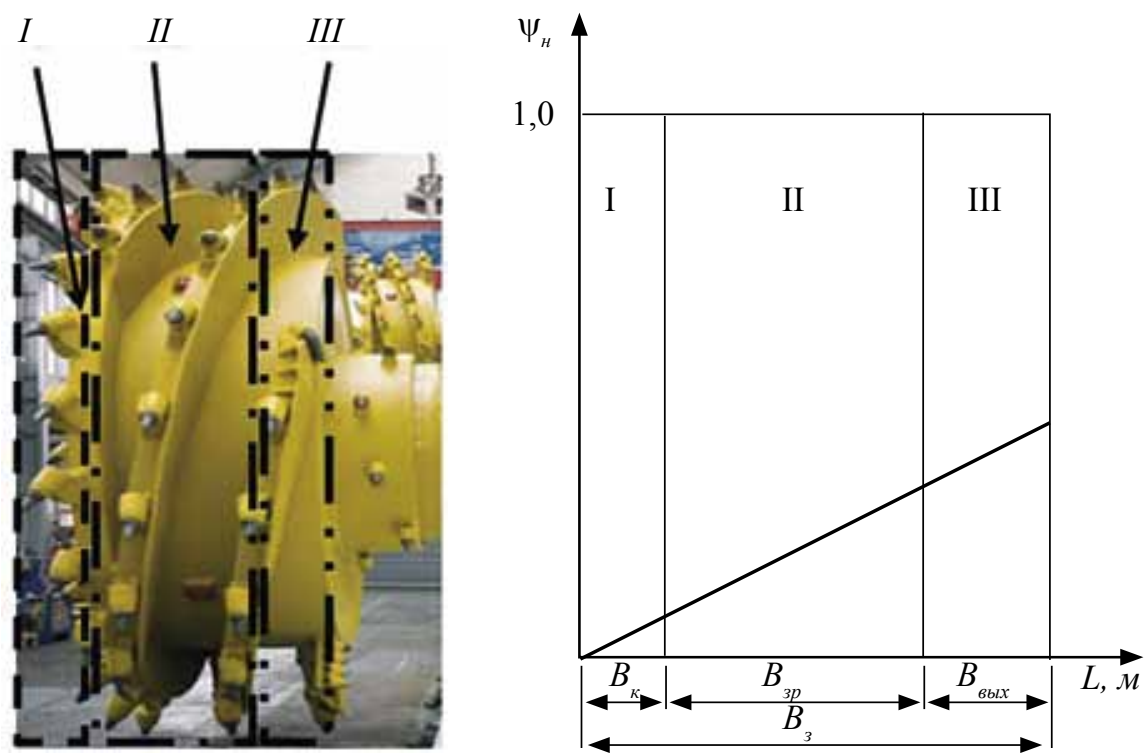

Pис. 4. Коэффициент заполнения сечения шнека по ширине захвата $B$

Fig. 4. Coefficient of screw conveyor cross-section filling by $B_{3}$ web width. conveyor work space

ного органа. При детальном рассмотрении процесс погрузки в целом по физической его сущности может быть представлен тремя разными процессами, проходящими в смежных зонах I, II, III (рис. 4).

Значения коэффициента заполнения и интенсивность циркуляции материала в шнеке изменяются по ширине захвата $B_{3}$ (см. рис. 4). В кутковой зоне I, поток отделенного от массива угля мал, не сформировано тело волочения, повышены метание, циркуляция и измельчение угля. В зоне II (зона разрушения массива забойными резцами) коэффициент заполнения шнека возрастает, формируется тело волочения. В зоне III (выгрузки угля на конвейер) коэффициент заполнения шнека увеличивается из-за подпора потока, что вызывается ограниченной пропускной способностью погрузочного окна.

При попутном вращении шнека поток расположен между почвой и щитком (см. рис. 3, б). При равной производительности шнеков по отбойке угля высота потока в этом случае ниже, чем при встречном движении, при этом снижается интенсивность циркуляции. Вместе с тем увеличение площади потока снижает его скорость.

\section{ЗАКЛЮЧЕНИЕ}

Исходя из вышеизложенного, можно сделать следующие выводы:

- процесс погрузки угля на конвейер недостаточно исследован, сущеличивается. Скорость потока при постоянных значениях частоты вращения, числа заходов и хода шнека будет неизменной. Возможен момент, когда материал будет скатываться на обечайку шнека и перекидываться в зону зачистного щитка. Здесь он или остается на почве пласта при отсутствии зачистного щитка (рис. 3, в), увеличивая высоту непогруженного слоя $H_{\text {o }}$ [1], либо будет собираться движущимся щитком и подаваться шнеком на конвейер и частично увлекаться в зону рабочего пространства шнека, образуя поток циркулирующего материала.

На рис. 3 показано, что поток угля не выгружается по всей площади сечения шнека. Зона его выгрузки зависит от геометрических и режимных параметров шнека. В реальных конструкциях площадь погрузочного окна ограничена в зоне выгрузки диаметром ступицы шнека, высотой борта забойного конвейера и размерами корпуса редуктора шнека. Ограниченные размеры окна увеличивают сопротивление перемещению угольного потока, что приводит к повышению коэффициента заполнения шнека.

При встречном вращении (см. рис. 3, a, в) и увеличении скорости подачи увеличивается площадь потока угля, расположенного в рабочем пространстве шнека $[10,11,12]$. Увеличение высоты потока приводит к росту циркуляции угля в рабочем пространстве шнекового исполнитель- ственно значимые затраты энергии, попутное измельчение угля и пылеобразование оказывают негативное влияние на эффективность процесса добычи;

- исследуемый процесс перемещения угля на конвейер шнековым исполнительным органом следует рассматривать состоящим из трех сопряженных процессов: выгрузки угля из кутковой зоны; транспонирования угля лопастями вдоль шнека по ширине захвата и продавливания сыпучего груза на конвейер через окно погрузки;

- необходимы исследования влияния коэффициента заполнения шнека и размера площади погрузочного окна на интенсивность циркуляции угля и эффективность процесса погрузки;

- необходимы поиск и разработка технических решений, обеспечивающих уменьшение интенсивности циркуляции и измельчения угля, уменьшение сопротивления его перемещению увеличением окна погрузки.

\section{Список литературы}

1. Солод В.И., Гетопанов В.Н., Рачек В.М. Проектирование и конструирование горных машин и комплексов. М.: Недра, 1982. 350 с.

2. Wang F., Tu S., Bai Q. Practice and prospects of fully mechanized mining technology for thin coal seams in 
China // Journal of the South African Institute of Mining and Metallurgy. 2012. Vol. 112(2). P. 161-170.

3. Peng S.S. Longwall Mining. U.S.: $2^{\text {nd }}$ edition, October 2006. $621 \mathrm{p}$.

4. Беликов К.Н. Экспериментальные исследования погрузочной способности шнекового исполнительного органа выемочной машины // Сборник научных трудов ПНИУИ. 1973. Вып. 16. С.135-146.

5. Шпитбаум И.М. Определение режимов работы слабонаклонного винтового конвейера // Вестник машиностроения. 1970. №4. С. 8-14.

6. Вернер В.Н. Исследование и обоснование рациональныхпараметров шнековыхпогрузочно-транспортирующих органов выемочных машин: дис. ...доктора. техн. наук. Кемерово, 1999. 319 с.

7. Банников А.А. Снижение усилий отделения угля от массива совершенствованием привода резца выемочного модуля: дис. ....канд. техн. наук. СПб: Горный университет, 2012. 157 c.
8. Машины и инструмент для бурения скважин в угольных шахтах / М.С. Сафохин, Б.А. Катанов, В.Е. Тарасенко, А.А. Алейников. М.: Недра, 1972. 216 с.

9. Ayhan M. и Eyyuboglu E.M. Comparison of globoid and cylindrical shearer drums'loading performance //The Journal of The South African Institute of Mining and Metallurgy. 2006. Vol. 106. P. 51-56.

10. Kuidong Gao, Changlong Du, Jianghui Dong и Qingliang Zeng. Influence of the Drum Position Parameters and the Ranging Arm Thickness on the Coal Loading Performance // Minerals. 2015. Vol. 5. P. 723-736. doi: 10.3390/min5040520

11. Skryabin R.M., Timofeev N.G. Development of an innovative shneko-heat-sink boring shell for drilling of shurfowells in the conditions of a kriolitozona // Eurasian mining. 2016. N 1. P. 33-36.

12. Zvonarev I.E., Shishlyannikov D.I. Efficiency improvement of loading of potassium ore by means of «Ural-20R» headingand-winning machine // IOP Conference Series: Earth and Environmental Science. 2017. Vol. 87. 022025.

UDC 622.232.72.054:622.647.1 @ V.V. Gabov, K.L. Nguyen, V.X. Nguyen, T.B. Le, D.A. Zadkov, 2018

COAL MINING EQUIPMENT

ISSN 0041-5790 (Print) • ISSN 2412-8333 (Online) • Ugol' - Russian Coal Journal, 2018, № 2, pp. 32-35

Title

THE RATIONALE OF GEOMETRIC AND MODAL PARAMETERS OF CUTTER DRUMS ENSURING

THE EFFICIENCY OF COAL LOADING ONTO A DOWNHOLE CONVEYOR

DOI: http://dx.doi.org/10.18796/0041-5790-2018-2-32-35

\section{Authors}

Gabov V.V. ${ }^{1}$, Nguyen K.L. ${ }^{1}$, Nguyen V.X. ${ }^{1}$, Le T.B. ${ }^{1}$, Zadkov D.A.

1 "Saint-Petersburg Mining University" (Mining University), the Federal State Budgetary Educational Institution of Higher Education (FSBEI HE),

Saint-Petersburg, 199106, Russian Federation

\section{Authors' Information}

Gabov V.V., Doctor of Engineering Sciences, Professor, Department of mechanical engineering,

Nguyen K.L., Postgraduate student of the mechanical engineering, e-mail: khaclinhhumg@gmail.com

Nguyen V.X., Postgraduate student of the mechanical engineering, Le T.B., Postgraduate student of the mechanical engineering

Zadkov D.A., PhD (Engineering), Associate professor, Department of mechanical engineering,

\section{Abstract}

Processes of coal unloading from destruction zone and its loading onto the downhole conveyor by cutter drum of shearer in complex-mechanized clearing faces of coal mines are analyzed. Possibilities of increasing efficiency of coal loading on the downhole conveyor by reduction criteria of additional grinding and specific energy consumption by increasing of the sectional area of loading window and volume of the loading zone on the conveyor are considered.

Figures:

Fig. 1. Screw conveyor mass haul

Fig. 2. Screw operating device broken-down coal $Q_{m p}$ and circulating coal $Q_{u}$ ratio in the screw conveyor section filling index function [1]

Fig. 3. Diagrams of broken-down coal layout in the second advance screw conveyor work space

Fig. 4. Coefficient of screw conveyor cross-section filling by $B_{3}$ web width.

\section{Keywords}

Coal, Underground mining, Clearing face, Shearer, Cutter drum, Conveyor, Loading, Efficiency.

\section{References}

1. Solod V.I., Getopanov V.N. \& Rachek V.M. Proektirovanie i konstruirovanie gornyh mashin i kompleksov [Mining machines and complexes design and construction]. Moscow, Nedra Publ., 1982, 350 p.
2. Wang F., Tu S. \& Bai Q. Practice and prospects of fully mechanized mining technology for thin coal seams in China. Journal of the South African Institute of Mining and Metallurgy, 2012, Vol. 112(2). pp. 161-170.

3. Peng S.S. Longwall Mining. U.S.: 2nd edition, October 2006.621 p.

4. Belikov K.N. Eksperimentalnye issledovaniya pogruzochnoy sposobnosti shnekovogo ispolnitelnogo organa vyemochnoy mashiny [Experimental studies of mining machine screw operating device loading capacity]. PNIUI collection of scientific papers, 1973, issue 16, pp.135-146.

5. Shpitbaum I.M. Opredelenie rezhimov raboty slabonaklonnogo vintovogo konveyera [Low inclined screw conveyor operation modes determination]. Vestnik mashinostroeniya - Machine Building Newsletter, 1970, No. 4, pp. 8-14. 6.VernerV.N. Issledovanieiobosnovanie ratsionalnyh parametrov shnekovyh pogruzochno-transportiruyushchih organov vyemochnyh mashin. Diss. dokt. techn. nauk [Mining machines screw loading and conveying devices rational parameters investigation and substantiation. Dr. eng. sci. diss.]. Kemerovo, 1999, 319 p.

7. Bannikov A.A. Snizhenie usiliy otdeleniya uglya ot massiva sovershenstvovaniem privoda reztsa vyemochnogo modulya. Diss. kand. techn. nauk. [Coal breaking off force reduction through mining block cutter actuator improvement. PhD (Eng.) diss.]. St-Petersburg, Mining University Publ., 2012, 157 p. 8. Safokhin M.S., Katanov B.A., Tarasenko V.E. \& Aleinikov A.A. Mashiny i instrument dlya bureniya skvazhin $v$ ugolnyh shahtah [Coal mines borehole drilling machines and tools]. Moscow, Nedra Publ., 1972, 216 p.

9. Ayhan M. \& Eyyuboglu E.M. Comparison of globoid and cylindrical shearer drums'loading performance. The Journal of The South African Institute of Mining and Metallurgy, 2006, Vol. 106, pp. 51-56.

10. Kuidong Gao, Changlong Du, Jianghui Dong \& Qingliang Zeng. Influence of the Drum Position Parameters and the Ranging Arm Thickness on the Coal Loading Performance. Minerals, 2015, Vol. 5, pp. 723-736. doi: 10.3390/ $\min 5040520$

11. Skryabin R.M. \&Timofeev N.G. Development of an innovative shneko-heatsink boring shell for drilling of shurfo-wells in the conditions of a kriolitozona. Eurasian mining, 2016, No. 1, pp. 33-36.

12. Zvonarev I.E. \& Shishlyannikov D.I. Efficiency improvement of loading of potassium ore by means of "Ural-20R" heading-and-winning machine. IOP Conference Series: Earth and Environmental Science, 2017, Vol. 87. 


\section{ФГБУ «ГУРШ»- двадцать лет спустя}

DOI: http://dx.doi.org/10.18796/0041-5790-2018-2-36-39

\section{МОИСЕЕНКОВ Андрей Валентинович}

Канд. экон. наук, директор ФГБУ «ГУРШ», 119019, г. Москва, Россия, e-mail:gursh@gursh.ru

В статье представлены итоги работы ФГБУ «ГУРШ» по реализациимероприятий по ликвидации особо убыточных шахт и разрезов за двадцать лет. Дана общая оценка результатов реструктуризации угольной промышленности России. Представлены показатели, характеризующие результаты текущей работы, а также мероприятия на этапе завершения реструктуризации. Ключевые слова:угольная промышленность, реструктуризация, горноэкологический мониторинг, экология, социальная инфраструктура.

\section{ВВЕДЕНИЕ}

В 1993-1994 гг. в России начался процесс реструктуризации угольной отрасли. Основными целями ее являлись: формирование конкурентоспособныхугольных компаний, обеспечивающих самофинансирование в длительной перспективе; обеспечение социальной защищенности высвобождаемых трудящихся отрасли; снижение государственной дотации предприятиям отрасли; социально-экономическое и экологическое оздоровление угледобывающих регионов.

Инициатором реструктуризации угольной отрасли выступила компания «Росуголь», которая и осуществляла эти работы в период с 1993 по 1997 г.

Во исполнение постановления Правительства Российской Федерации от 20.11.1997 № 1462 «О совершенствовании управления угольной промышленностью» создано и зарегистрировано 22.12.1997 как юридическое лицо Государственное учреждение по вопросам реорганизации и ликвидации нерентабельных шахт и разрезов «ГУРШ», которое в ноябре 2010 г. преобразовано в федеральное государственное бюджетное учреждение по вопросам реорганизации и ликвидации нерентабельных шахт и разрезов «ГУРШ» (ФГБУ «ГУРШ»).

\section{РЕСТРУКТУРИЗАЦИЯ УГОЛЬНОЙ ОТРАСЛИ}

ФГБУ «ГУРШ» с февраля 1998 г. принимает самое непосредственное участие в процессах, связанных с реструктуризацией угольной отрасли России.

Мировая практика не знает более масштабных объемов ликвидации нерентабельных, особо убыточных шахт и разрезов, приведения последствий от вредного влияния горных работ целых угольных бассейнов в безопасное состояние, разгазирования и выполнения мероприятий по предотвращению затопления огромного выработанного пространства, надежной изоляции горных выработок, приведения промышленных площадок в экологически нормаль- ное состояние, рекультивации нарушенных земель для хозяйственного использования местными органами, создания нормальных социальных условий для проживания населения в шахтерских городах и поселках $[1,2,3]$. Все эти годы работники ФГБУ «ГУРШ» стоят на передовых позициях по решению целого комплекса правовых, технических, экологических и социальных проблем реструктуризации угольной промышленности в стране и, безусловно, добились впечатляющих результатов.

Положительные результаты работы ФГБУ «ГУРШ» во многом зависят от повседневного сотрудничества с Департаментом угольной и торфяной промышленности Минэнерго России, экономическими и юридическими службами министерства.

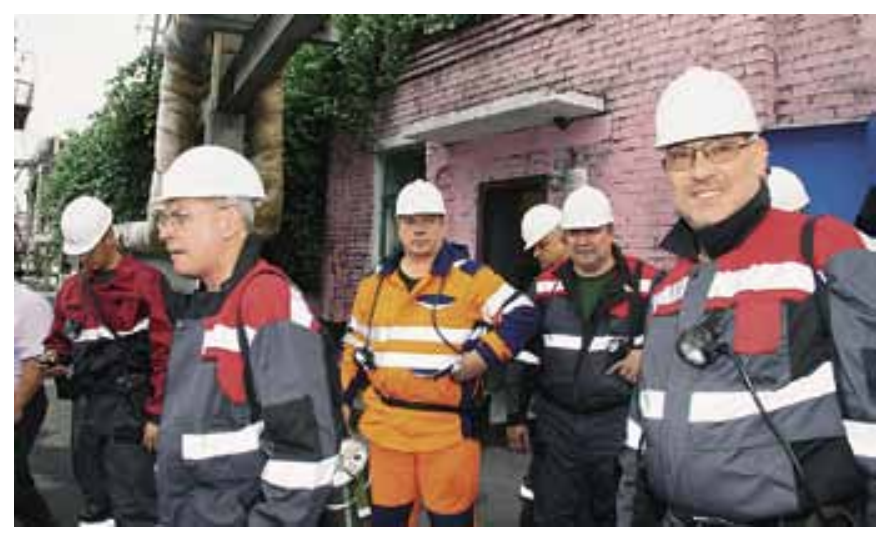

В первом ряду слева заместитель министра энергетики Российской Федерачии А.Б. Яновский и директор ФГБУ «ГУРШ» А.В. Моисеенков

Важную роль играет то, что руководит этим направлением высококвалифицированный опытный горный инженер, изнутри знающий все этапы горного производства, заместитель министра энергетики Российской Федерации Анатолий Борисович Яновский. Именно благодаря его деловому подходу, принципиальности и требовательности все вопросы реструктуризации угольной промышленности решаются своевременно и качественно.

В течение этих 20 лет, несмотря на внесение отдельных изменений в выполняемые функции и задачи, ФГБУ «ГУРШ» успешно осуществляет деятельность по подготовке предложений и реализации мероприятий по реструктуризации угольной промышленности в части технической ликвидации особо убыточных и неперспективных предприятий; разработке проектов ликвидации организаций угольной промышленности и проектно-сметной документации по предусмотренным в них объектам; сносу ветхого жилищного фонда, ставшего в результате ведения горных работ непригодным для проживания по критериям безопасности, и содействия гражданам в приобретении (строительстве) жилья взамен сносимого; реконструкции и замены пострадавших в связи с ликвидацией шахт и разрезов объектов 
социальной инфраструктуры шахтерских городов и поселков во всех основных угледобывающих регионах Российской Федерации; участия в мониторинге хода работ по ликвидации организаций угольной промышленности.

В 2002 г. во всех основных угледобывающих регионах Российской Федерации были созданы филиалы учреждения, основными видами деятельности которых являются:

- технический контроль за ликвидацией горных выработок, выходящих на дневную поверхность, разборкой зданий и сооружений технологического комплекса, демонтажем оборудования и выдачей его на поверхность;

- координация проектных, научно-исследовательских и технических работ по экологическим и социальным аспектам, связанным с ликвидацией шахт;

- ликвидация последствий вредного влияния горных работ на подработанных территориях закрытых шахт;

- реконструкция объектов социнфраструктуры в связи с закрытием шахт;

- исследовательские работы по экологическим проблемам.

Филиалы ФГБУ «ГУРШ» работают в тесном взаимодействии с местными администрациями и с созданными в угледобывающих регионах центрами социально-экологического мониторинга.

За годы реструктуризации в 24 субъектах Российской Федерации (78 шахтерских муниципальных образованиях) ликвидировано 203 угледобывающих предприятия, из них 188 шахт и 15 разрезов. Все организации- юридические лица исключены из единого государственного реестра.

Структура финансирования мероприятий по реструктуризации угольной промышленности России на 01.01.2018 приведена на рис. 1.

По состоянию на 01.01.2018 за счет средств федерального бюджета профинансированы технические работы по ликвидации организаций угольной промышленности на сумму 28 963,2 млн руб., за счет чего:

- ликвидированы все горные выработки общей протяженностью 5 тыс. км; снесены 5247 зданий и сооружений в объеме 15,2 млн куб. м;

- реконструированы и построены 54 водоотливных комплекса;

- построено 12 очистных сооружений шахтных вод;

- потушены пожары на 65 породных отвалах и 7 пожаров в подземных горных выработках;

- завершены работы по капитальному ремонту, реконструкции пострадавших в результате подработки горными работами и строительству 61 социального объекта;

- выполнены 83 мероприятия по обеспечению защиты от затопления смежных действующих шахт, от загрязнения питьевых источников и подтопления объектов земной поверхности шахтными водами;

- завершены работы по рекультивации 6 740,9 га нарушенных земель по 222 рабочим проектам;

- осуществлялось ведение мониторинга экологическихпоследствийлик- видации угольных (сланцевых) шахт и разрезов в Подмосковном, Печорском и Кузнецком угольных бассейнах, Восточном Донбассе, Уральском регионе, Приморском крае, Сахалинской и Ленинградской областях, включая мероприятия по оперативной ликвидации провалов земной поверхности.

За этотже период ФГБУ «ГУРШ» проведена интенсивная работа по реализации программ местного развития и обеспечения занятости населения шахтерских городов и поселков.

Приведено в состояние, пригодное для дальнейшего использования, 802 социальных объекта по реконструкции и замене объектов социальной инфраструктуры, пострадавших в связи с ликвидацией шахт и разрезов, на сумму 8 720,8 млн руб., полностью завершены работы на 794 объектах.

Проведен снос ветхого жилищного фонда, ставшего в результате ведения горных работ на ликвидируемых шахтах непригодным для проживания по критериям безопасности, в объеме 2 705,5 тыс. куб. м с затратами 456,1 млн руб.

Переселению из ветхого жилья подлежат 52926 семей. По состоянию на 01.01.2018 переселено 42200 семей с затратами 40 242,5 млн руб.

Количество переселенных семей по отдельным субъектам Российской Федерации и затраты на содействие гражданам в приобретении (строительстве) жилья приведены на рис. 2, 3.

На эксплуатацию 13 природоохранных объектов из федерального бюджета на 01.01.2018 выделено 1 706,4 млн руб.

Реализация и финансирование мероприятий по реструктуризации угольной промышленности осуществляются в соответствии с требованиями законодательства Российской Федерации на основании разработанной и утвержденной проектной и рабочей документации, на разработку (корректировку) и экспертизу которой за период с 1994 по 2018 г. из средств федерального бюджета направлено 2 252,7 млн руб.

Проводимая Минэнерго России, при активном участии ФГБУ «ГУРШ», работа позволила угольной отрасли успешно справиться с трудностями, возникшими и на начальном этапе проводимых в угольной промышленности реформ, и

Всего: 82 341,7 млн руб.

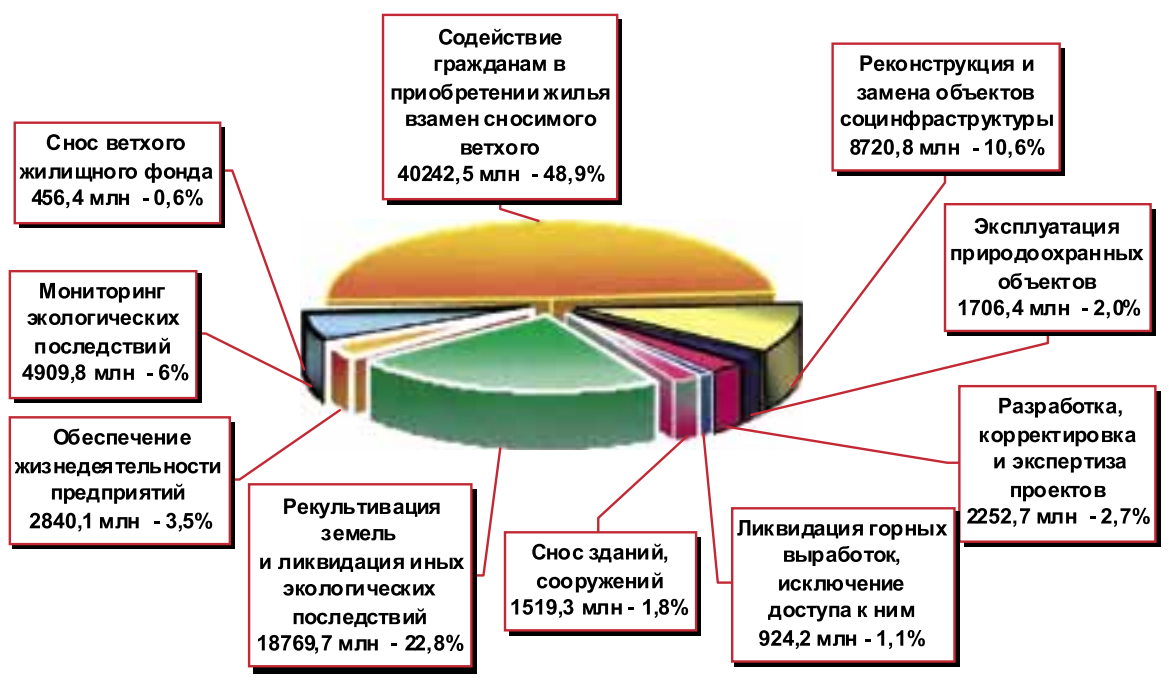

Puc. 1. Структура финансирования мероприятий по реструктуризации угольной промышленности России на 01.01.2018. 


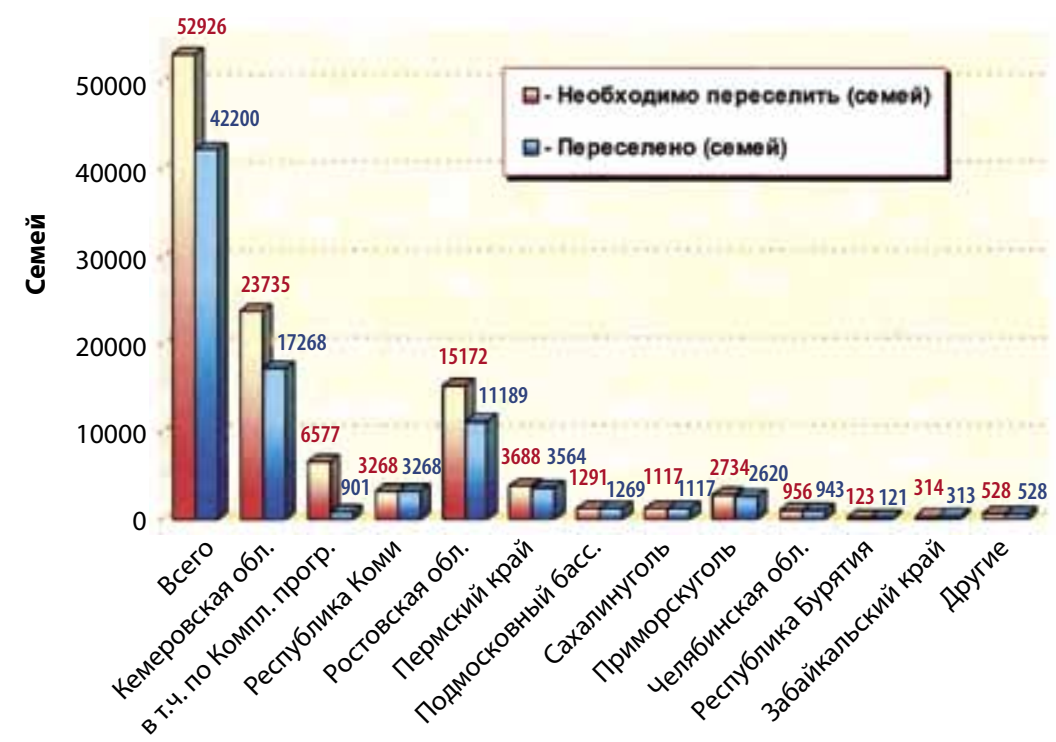

Рис. 2. Количество переселенных семей по основным регионам на 01.01.2018.

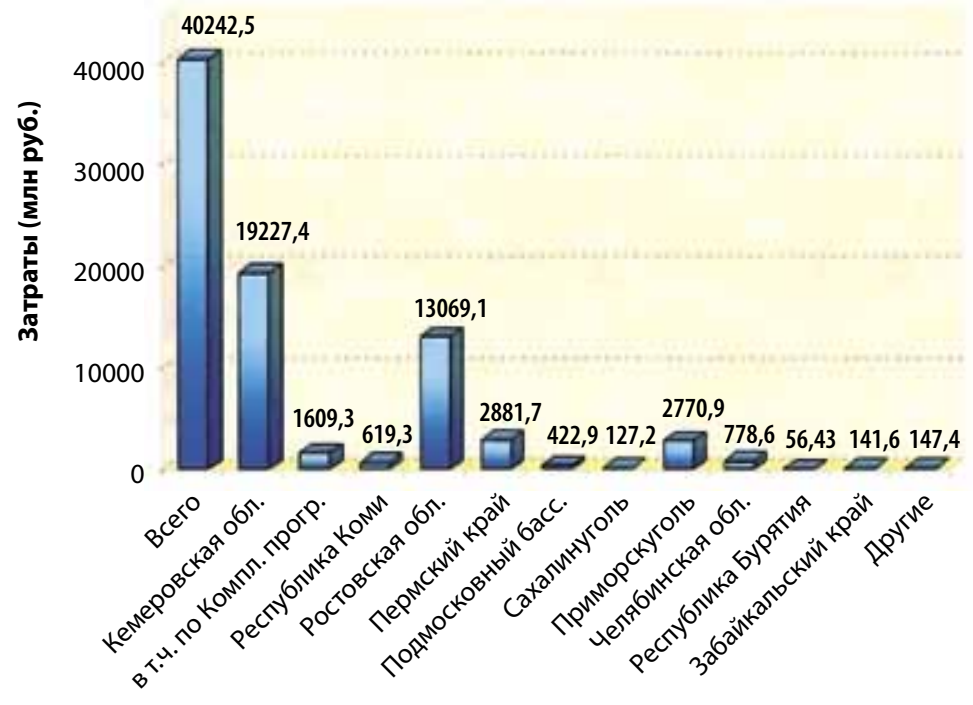

Puс. 3. Затраты на содействие гражданам в приобретении жилья по основным регионам на 01.01.2018, млн руб.

в 2008-2009 гг., и в 2014-2015 гг., когда резко ухудшился экономический фон для предприятий. Угольная отрасль еще раз продемонстрировала свою устойчивость и конкурентоспособность. Угольные компании наращивали объемы добычи, обогащения и сортировки угля.

С 1994 г. численность работников отрасли сократилась с 950 тыс. до 150 тыс. человек, производительность труда выросла в три раза, исключились полностью дотации из федерального бюджета на поддержку шахт.

В последние годы ФГБУ «ГУРШ» активно работает над проблемой ликвидации нерентабельных шахт, не имеющих государственного пакета акций. По этим шахтам нет четких государственных нормативно-правовых актов, а организация и координация ликвидационных работ возложены на межведомственные рабочие комиссии, в состав которых входят заинтересованные министерства, ведомства и администрации регионов. Организация всех заседаний межведомственных комиссий, подготовка всего комплекса документации, координация работ и контроль за исполнением решений этих комиссий осуществляет ФГБУ «ГУРШ».

Так, в Кузбассе в 2015 г. была принята Комплексная программа поэтапной ликвидации убыточных шахт, расположенных на территории городов Прокопьевска, Киселевска, АнжероСудженска, и переселения жителей с подработанных территорий (І очередь- 2015-2017 гг.), утвержденная губернатором Кемеровской области и министром энергетики Российской Федерации, которая предусматривает выполнение конкретных мероприятий по консервации 12 шахт, находящихся в частной собственности.

Изучив совместно с Минэнерго России передовой опыт в различных областях производственной деятельности, проведя анализ обеспечения безопасного ведения горных работ и использовав собственный опыт поэтапной ликвидации особо опасных шахт, при непосредственном участии ФГБУ «ГУРШ» в указанной программе были привлечены дополнительные ресурсы для ликвидации убыточных шахт и реконструкции объектов социальной инфраструктуры, в результате чего в Кузбассе на принципах государственно-частного партнёрства реализована І очередь Комплексной программы поэтапной ликвидации убыточных шахт, расположенных на территории городов Прокопьевска, Киселевска, Анжеро-Судженска, и переселения жителей с отработанных территорий. При реализации этой программы использовался новый механизм предоставления права пользования новыми участками недр с обременением недропользователя обязательствами по проведению ликвидационных мероприятий на убыточных шахтах. В настоящее время разработана и находится на утверждении II очередь Комплексной программы, предусматривающая полную ликвидацию 12 шахт.

Не менее сложным является вопрос ликвидации уникального по своим параметрам угольного разреза «Коркинский». По решению Правительственной комиссии по предупреждению и ликвидации чрезвычайных ситуаций и обеспечению пожарной безопасности с начала 2011 г. действует межведомственная рабочая группа, образованная Минэнерго России, в состав которой вошли представители различных ведомств и организаций, основной задачей которой является мониторинг в районе разреза «Коркинский» с целью недопущения возможных негативных ситуаций.

ФГБУ «ГУРШ» в соответствии с решениями Правительственной комиссии и Межведомственной рабочей группы начиная с 2012 г. активно участвовало в разработке и контроле за выполнением комплекса мероприятий по обеспечению устойчивости бортов разреза, локализации эндогенных пожаров, блокированию оползневых подвижек, направленных на обеспечение технической безопасности деятельности разреза, защиту граждан, проживающих в его прибортовой зоне.

Все эти годы ФГБУ «ГУРШ» контролировало объемы и сроки выполнения комплекса инженерных мероприятий, что позволило стабилизировать деформационные процессы на бортах разреза, переселить жителей пос. Роза из аварийногожилья, значительно уменьшить количество очагов 
эндогенных пожаров в недрах разреза, обеспечить мониторинг негативных последствий от ведения горных работ.

В настоящее время ФГБУ «ГУРШ» совместно с ЗАО «Русская медная компания» и администрацией Челябинской области решает комплекс вопросов, предусмотренный Дорожной картой по ликвидации отработанной выработки разреза путем заполнения и рекультивации с размещением отходов обогатительной фабрики медного производства.

Отметим, что впервые в истории отечественного горного дела может быть реализован такой комплексный проект, связанный сликвидацией последствия ведения горных работ и решением экологических проблем.

В ближайшее время предстоит разработать и осуществить комплекс ликвидационных работ по остановленным 7 шахтам Ростовской области, которые находились в частной собственности, и не допустить неуправляемых перетоков и подтопления жилых территорий шахтными водами.

За эти годы сделано многое, но работы по завершению реструктуризации угольной промышленности России будут продолжены.

В перспективе намечается в полном объеме реализовать обязательства государства по обеспечению мер социальной поддержки высвобожденных работников ликвидированных предприятий и охраны территорий от экологических и иных последствий добычи угля.

Использование наиболее современных экологически чистых технологий при модернизации старых и строительстве новых угледобывающих и углеперерабатывающих предприятий позволит минимизировать вредные выбросы в окружающую среду.

Объем необходимых бюджетных средств на завершение мероприятий по технической ликвидации и программам местного развития составляет 30486 млн руб. В настоящее время согласно Федеральному закону от 05.12.2017 № 362Ф3 «О федеральном бюджете на 2018 год и на плановый период 2019 и 2020 годов» предусматривается ежегодное финансирование в рамках бюджета направлений, курируемых ФГБУ «ГУРШ», в размере 2000 млн руб., что позволит в течение 15 лет завершить данные мероприятия. Конечно, этот срок можно сократить в случае ежегодного увеличения финансирования в рамках возможностей бюджета.

\section{ЗАКЛЮЧЕНИЕ}

Прошедшие двадцать лет были наполнены напряженной работой, победами, достижениями и разочарованиями, мы создавали сплоченный коллектив, развивали его, решали возникающие в регионах проблемы в сфере трудовых, социальных правоотношений, встречались с руководством предприятий по наболевшим вопросам, формировали систему социального партнерства, на законодательном уровне закрепляли необходимость привлечения дополнительных ресурсов для ликвидации убыточных шахт, реконструкции объектов социальной инфраструктуры, проводили взвешенную кадровую политику, направленную в том числе на обеспечение преемственности поколений, и растили молодые кадры.

ФГБУ «ГУРШ», начавшее деятельность двадцать лет назад, продемонстрировало свою устойчивость и профессионализм. Здесь гордятся богатой историей, огромным опытом работы, и главное- своим коллективом, который и является самым ценным капиталом учреждения.
Высоко оценен труд сотрудников ФГБУ «ГУРШ» Правительством Российской Федерации, Минэнерго России и, что особенно впечатляет, лично Президентом Российской Федерации. Это подтверждается врученными правительственными и ведомственными наградами, благодарностями, почетными грамотами.

20 лет- это много или мало? Для человека- это значительный отрезок жизни в его биографии, для учреждения, у которого, надеюсь, впереди долгая жизнь- пожалуй, небольшой, но достойный отрезок в его истории.

Я поздравляю коллектив ФГБУ «ГУРШ» с нашим юбилеем! Желаю всем здоровья, успехов в работе, стабильного развития учреждения и экономики в целом, мира и благополучия.

\section{Список литературы}

1. Таразанов И.Г.Итоги работы угольной промышленности России за январь-декабрь 2016 года //Уголь. 2017. № 3. С. 3650. doi: 10.18796/0041-5790-2017-3-36-50. URL: http://www. ugolinfo.ru/Free/032017.pdf (дата обращения: 15.01.2018).

2. Таразанов И.Г. Итоги работы угольной промышленности России за январь-сентябрь 2017 года //Уголь. 2018. № 1. С. 18-32. doi: 10.18796/0041-5790-2018-1-18-32

3. Яновский А.Б. Основные тенденции и перспективы развития угольной промышленности России // Уголь. 2017. № 8. C.10-14. doi: 10.18796/0041-5790-2017-8-10-14. URL: http://www.ugolinfo.ru/Free/082017.pdf (дата обращения: 15.01.2018).

RESTRUCTURING

UDC 658.155:622.33(470):65.016.8 @ A.V. Moiseenkov, 2018

ISSN 0041-5790 (Print) • ISSN 2412-8333 (Online) •

Ugol' - Russian Coal Journal, 2018, № 2, pp. 36-39

Title

FEDERAL STATE BUDGETARY INSTITUTION ON REORGANIZATION AND LIQUIDATION OF NON-EFFICIENT MINES ("GURSH" FSBI) TWENTY YEARS LATER

DOI: http://dx.doi.org/10.18796/0041-5790-2018-2-36-39

\section{Author}

Moiseenkov A.V. ${ }^{1}$

${ }^{1}$ Federal State Budgetary Institution on Reorganization and Liquidation of Non-efficient Mines ("GURSH"FSBI), Moscow, 119019, Russian Federation

\section{Authors' Information}

Moiseenkov A.V., PhD (Economic), Director, e-mail: gursh@gursh.ru

\section{Abstract}

The articles presents the 20-year results of "GURSH" FSBI activities, aimed at extra non-efficient mines and open pits liquidation. It provides the general assessment of the Russian coal industry reorganization results. It presents the data, indicative of the current activities results, and describes the activities during the final reorganization stage.

\section{Keywords}

Coal Industry, Reorganization, Mining and ecological monitoring, Ecology, Social infrastructure.

\section{References}

1. Tarazanov I.G. Russia's coal industry performance for January - December, 2016. Ugol' - Russian Coal Journal, 2017, No. 3, pp. 36-50. doi: 10.18796/0041-5790-2017-3-36-50. Available at: http://www.ugolinfo.ru/ Free/032017.pdf (accessed 15.01.2018).

2. Tarazanov I.G. Russia's coal industry performance for January - September, 2017. Ugol' - Russian Coal Journal, 2018, No. 1, pp. 18-32. doi: 10.18796/0041-5790-2018-1-18-32.

3. Yanovsky A.B. Main trends and prospects of the coal industry development in Russia. Ugol' - Russian Coal Journal, 2017, No. 8, pp. 10-14. doi: 10.18796/0041-5790-2017-8-10-14. Available at: http://www.ugolinfo.ru/ Free/082017.pdf (accessed 15.01.2018). 


\section{Формирование и трансформация}

\section{институциональной системы регулирования структурных преобразований в угольной отрасли и на углепромышленных территориях России}

DOI: http://dx.doi.org/10.18796/0041-5790-2018-2-40-47

\author{
РОЖкОВ Анатолий Алексеевич \\ Доктор экон. наук, профессор, \\ Институт экономики и управления \\ промышленными предприятиями НИТУ «МИСИС», \\ 119049, г. Москва, Россия, \\ тел.: +7 (499) 230-24-78, \\ e-mail:aarozhkov@mail.ru
}

\section{СОЛОВЕНКО Игорь Сергеевич}

Канд. ист. наук, дочент,

Юргинский технологический институт (филиал)

ФГАОУ ВО «Начиональный исследовательский

Томский политехнический университет»,

652055 , г. Юрга, Россия,

тел.: +7 (38451) 7-77-62,

e-mail:solovenko71@mail.ru

В ноябре 1997 г. постановлением Правительства РФ № 1462 «О совершенствовании управления угольной промышленностью» были созданы два государственных учреждения - «ГУРШ» и «СОЦУГОЛЬ» (ныне ФГБУ), практическая деятельность которых началась двадцать лет назад - в феврале 1998 г. и которые до сих пор остаются опорными звеньями институциональной системы структурных преобразований на углепромышленных территориях. В этой связи представляется целесообразным проанализировать исторический опыт формирования и трансформации институциональной системы в ходе реструктуризации угольной промышленности, а также при государственной поддержке моногородов, в том числе угольной специализации. Ключевые слова: Россия, институциональная система, структурные преобразования, угольная отрасль, углепромышленные территории, моногорода.

\section{ВВЕДЕНИЕ}

Конец XX в. - начало XXI в. стали временем серьезных трансформаций во всех сферах общественной жизни суверенной России. Успех перемен в стране во многом определялся динамикой формирования и развития институциональных основ новой, либерально-демократической системы.
В этой связи особый интерес вызывает анализ опыта формирования и развития социально-экономических институтов в сфере угольной промышленности России, так как данная отрасль в течение рассматриваемого времени превратилась из «главного иждивенца» страны в одного из крупнейших доноров госбюджета [1], а некогда главные возмутители общественно-политического спокойствия в стране - шахтеры стали одной из социальных опор новой государственной системы. Сегодня уже можно не только давать оценки либеральным реформам в сфере угольной промышленности, но и определять стратегию укрепления институциональных основ социально-экономических преобразований на углепромышленных территориях России.

Цель статьи - показать особенности формирования и трансформации институциональной системы регулирования структурных преобразований в угольной отрасли и на территориях ее дислокации, прежде всего в углепромышленных моногородах России.

\section{ФОРМИРОВАНИЕ ИНСТИТУЦИОНАЛЬНОЙ СИСТЕМЫ В ПЕРИОД 1993-2000 гг.}

Процесс реформирования угольной промышленности в условиях системного перехода к либеральнорыночным отношениям в 1990-е годы имел свои особенности, которые во многом ослабляли экономический и социальный потенциал базовой отрасли народного хозяйства. Несмотря на уже второстепенную роль в топливно-энергетическом комплексе России, уголь по-прежнему имел определяющее значение в формировании макроэкономических процессов. Свободные цены на уголь могли серьезно дестабилизировать обстановку в народном хозяйстве, поэтому до июля 1993 г. угольщики не имели той ценовой свободы, которую уже имели предприятия и компании других отраслей. Потеря конкурентоспособности отрасли, по этой и ряду других причин, осложняла решение широкого спектра вопросов жизнедеятельности не только шахт и разрезов, но и всех углепромышленных территорий. В наиболее сложном положении оказались те из них, которые были не столь масштабны, а эксплуатация недр здесь имела 
долгосрочный период (например, Кизеловский угольный бассейн, имевший более чем 200-летнюю историю).

Системный характер проблем в угольной отрасли инициировал создание в ноябре 1993 г. нового органа, который должен был решать жизненно важные вопросы шахтеров - Межведомственной комиссии по социальноэкономическим проблемам угледобывающих регионов (МВК). На ее заседаниях рассматривался широкий спектр вопросов, которые напрямую затрагивали интересы шахтерских семей, а для их реализации привлекались органы власти и управления всех уровней, научноисследовательские учреждения, а также профсоюзы и первые представители угольного бизнеса. Появление данного органа можно считать первым шагом на пути формирования институциональной системы регулирования структурных преобразований на углепромышленных территориях России. Между тем структурное оформление институциональной базы в решении социальноэкономических проблем углепромышленных территорий подрывалось политическими противоречиями основных участников рассматриваемого процесса. В условиях отсутствия достаточных финансово-материальных средств и полномочий деятельность МВК свелась к роли органа, действующего в чрезвычайных обстоятельствах.

Тем временем отрасль нуждалась в системных реформах, которые бы позволили вывести ее на качественно иной, конкурентоспособный уровень. Революционным шагом в этом направлении стало принятое в 1994 г. решение о реструктуризации угольной промышленности России. Данный курс обещал не только выход российских шахт и разрезов на мировой рынок угля, но и решение еще более обострившихся к тому времени социальноэкономических проблем шахтерских семей - это снижение уровня жизни, отсутствие эффективного механизма социальной защиты и др.

Первый этап реструктуризации угольной промышленности (1994-1997 гг.) протекал весьма неоднозначно. Были серьезные достижения, но имелось немало проблем, которые с трудом преодолевались даже самыми перспективными угледобывающими предприятиями и компаниями. Очевидным был и хронический разрыв между экономическими интересами участников угледобычи и социальными обязательствами перед трудящимися отрасли.

Резкое обострение социальных проблем на углепромышленных территориях в середине 1990-х годов активизировало действия местных органов власти. В 1995 г. десятки шахтерских городов и поселков создали Ассоциацию шахтерских городов (АШГ). Ее основной целью стали консолидация и координация работы администраций углепромышленных городов и поселков, защита социально-экономических интересов их населения. АШГ стала противовесом отраслевым интересам шахтерских профсоюзов и приватизировавшихся угольных компаний. Во многом благодаря ее деятельности удалось наладить поступление средств на социальные программы без дополнительных этапов и посредников, а следовательно, без риска коррупции [2, с. 44]. Деятельность АШГ способствовала реализации важных социальных про- грамм на муниципальном уровне и обеспечению социальных гарантий горнякам и членам их семей; содействовала динамичному и рациональному развитию экономики шахтерских городов и поселков. Однако попытка институализировать социально-экономические процессы на углепромышленных территориях посредством создания АШГ имела ограниченный успех, так как сохранялась противоречивость интересов между местными органами власти и отраслевыми профсоюзами, а в некоторых случаях и представителями бизнеса. Недостаточным являлось и взаимодействие АШГ с федеральными органами власти, которые «не успевали» реагировать на проблемы угольной отрасли. Дефицит политико-экономических полномочий руководителей региональных органов власти также снижал уровень их взаимодействия с АШГ. Таким образом, в середине 1990-х годов еще отсутствовала четкая координация действий ключевых участников угольной политики как на уровне регионов, так и всей страны в целом.

В этих условиях центральной задачей являлось усиление взаимодействия между органами исполнительной власти всех уровней. Рост напряженности на всех углепромышленных территориях, особенно в ведущем, Кузнецком угольном бассейне страны, подталкивал все органы власти и управления к более активному вмешательству в решение шахтерских проблем. В условиях сохранения высокой степени централизации управления отраслью организовать все заинтересованные в выполнении такой задачи силы мог только главный исполнительный орган страны. В июле 1996 г. решением Правительства РФ в шестидесяти углепромышленных муниципальных образованиях были созданы Наблюдательные советы. В них вошли местные профсоюзные лидеры, представители администраций шахтерских городов и районов, руководители организаций угольной отрасли, влиятельные общественные деятели и представители местного бизнеса. Создание Наблюдательных советов стало важным этапом в части развития системы социального партнерства в угольной отрасли и демократических начал на углепромышленных территориях в целом.

Однако реструктуризация угольной промышленности нуждалась в серьезной корректировке ее регулирования на федеральном уровне. Важным решением Правительства РФ стало создание в ноябре 1997 г. двух государственных учреждений - «ГУРШ» и «СОЦУГОЛЬ»'. Их активная деятельность началась с февраля 1998 г., и в рамках своих компетенций они активно до сих пор взаимодействуют с органами исполнительной власти всех уровней, общественными организациями и профсоюзами. Ключевым элементом в реализации деятельности данных организаций стала широкая опора на отечественную науку и практику. Серьезная теоретическая и мето-

1 ГУ «ГУРШ»-Государственное учреждение по вопросам реорганизации и ликвидации нерентабельных шахт и разрезов (ныне ФГБУ «ГУРШ»).

ГУ «СОЦУГОЛЬ» - Государственное учреждение по координации программ местного развития и решению сочиальных проблем, вызванных реструктуризацией предприятий угольной промышленности (ныне ФГБУ «СОЦУГОЛЬ»). 
дологическая база, ориентированная на прогнозирование и планирование социально-экономических процессов, позволила эффективно расходовать средства государственной поддержки и совместно с местными властями оказывать адресную помощь углепромышленным территориям и трудовым коллективам ликвидируемых убыточных организаций.

В рамках деятельности ГУ «ГУРШ» стали более эффективно решаться такие вопросы, как снос ветхого жилья, реконструкция социальной инфраструктуры, эксплуатация природоохранных объектов и др. Если в первые годы реструктуризации угольной отрасли наибольший объем средств из федерального бюджета направлялся на технические работы по ликвидации организаций, то начиная с 1998 г. акцент реформ сместился на реализацию социально ориентированных мероприятий в рамках программ местного развития и восстановления экологического баланса в районах, где велись разработки угля.

ГУ «СОЦУГОЛЬ» разработало и далее активно реализовывало комплексную систему регулирования и оптимизации социальных последствий структурной перестройки угольной промышленности, основными особенностями которой являлись следующие: адресный характер социальной защиты высвобождаемых работников; повышение уровня целевого использования средств государственной поддержки путем перехода на казначейскую систему доведения средств до их получателей; разработка новых социальных технологий, связанных с обеспечением занятости высвобождаемых работников; развитие системы социального партнерства между субъектами реструктуризации угольной отрасли и др. [3, с. 99-104].

В середине 1998 г. в угольной промышленности появились очертания новой институциональной системы социально ориентированного регулирования структурных преобразований в угольной отрасли и на углепромышленных территориях. Центральным звеном новой системы стали администрации углепромышленных муниципальных образований - конечные получатели средств государственной поддержки на реализацию программ местного развития и обеспечение занятости населения на основе развития малого и среднего предпринимательства. На углепромышленных территориях начали действовать такие новые институциональные структуры, как муниципальные фонды поддержки предпринимательства, бизнес-центры, инвестиционные (инновационные) фонды местного развития.

Благодаря позитивным процессам в деле реформирования отрасли с конца 1998 г. приоритетными направлениями реструктуризации угольной промышленности стали финансирование мероприятий по социальной защите трудящихся, созданию безопасных условий работы и финансирование технических работ по ликвидации особо убыточных и неперспективных угольных (сланцевых) шахт и разрезов, предоставление инвестиций и др. [4].

Впервые за годы реформ динамика угледобычи стала расти, существенно выросла производительность труда в отрасли, снизились травматизм и число несчастных случаев на угольном производстве. В 1999 г. на углепромышленных территориях было введено около 600 новых рабочих мест по добыче угля (в 1998 г. только 242), почти девять тысяч рабочих мест в сфере малого и среднего бизнеса неугольного профиля [5, с. 38]. Позитивные результаты деятельности в сфере угольной промышленности стали одним из факторов роста доверия шахтеров и резкого снижения уровня конфликтности на углепромышленных территориях [6, 7]. Все эти положительные факты свидетельствуют о создании в конце 1990-х годов достаточно эффективной институциональной системы регулирования структурных преобразований в угольной отрасли и на углепромышленных территориях России.

\section{ТРАНСФОРМАЦИЯ}

\section{ИНСТИТУЦИОНАЛЬНОЙ СИСТЕМЫ}

(начало 2000-х гг.)

До рубежа 2000-х гг. формирование институциональной системы проходило в условиях острых политических и экономических противоречий. В начале XXI в. ее развитие вышло на качественно новый уровень. Этому способствовали: укрепление государственной стабильности, проведение ряда социально-экономических реформ (налоговой, земельной, пенсионной, банковской и других), а также повышение темпов экономического роста.

В период 2004-2008 гг. созданная в ходе реструктуризации угольной промышленности институциональная система претерпела значительную трансформацию, связанную прежде всего с реформированием исполнительных органов власти на федеральном уровне. Так в соответствии с Указом Президента России были образованы Министерство промышленности и энергетики РФ, а также входящее в его структуру Федеральное агентство по энергетике (Росэнерго), осуществляющее свою деятельность непосредственно и через подведомственные организации (в том числе через государственные учреждения «ГУРШ» и «СОЦУГОЛЬ»), во взаимодействии с другими федеральными органами исполнительной власти, органами исполнительной власти субъектов Российской Федерации, органами местного самоуправления, общественными объединениями и иными организациями [8]. Таким образом, институциональная система в сфере угольной отрасли и на углепромышленных территориях России приобрела более централизованный характер.

В связи супорядочением состава координационных, совещательных, иных органов и групп, образованных Правительством РФ, была упразднена и МВК. Основные этапы реструктуризации угольной промышленности были завершены, а первоочередные социально-экономические задачи выполнены [9]. Соответственно, на региональном уровне прекратили свою деятельность региональные MBK, а на муниципальном - Наблюдательные советы, которые трансформировались в различные общественные институты (общественные советы) при региональных и муниципальных органах власти.

В ходе дальнейшего реформирования федеральных органов исполнительной власти было упразднено Минпромэнерго России и создано Министерство энергетики Российской Федерации, осуществляющее и в настоящее время функции по выработке и реализации государственной политики и нормативно-правовому регу- 
лированию в сфере топливно-энергетического комплекса, в том числе по вопросам угольной промышленности [10]. Данные преобразования окончательно сформировали существующую сегодня отраслевую институциональную систему.

На заключительном этапе структурныхпреобразований угольной промышленности (начиная с 2005 г.) началась реализация новой сбалансированной территориальноотраслевой корпоративной социальной политики с элементами государственного регулирования в части завершения бюджетного финансирования социально ориентированных мероприятий реструктуризации по линии Минэнерго России (ФГБУ «Соцуголь» и «ГУРШ»), окончание которых предполагается к 2020 г. Данные мероприятия включают: обеспечение бесплатным пайковым углем льготных категорий граждан; дополнительное негосударственное пенсионное обеспечение; реализацию программ местного развития (ПМР).

Всего в рамках созданной институциональной среды регулирования структурных преобразований в угольной отрасли и на углепромышленных территориях России по состоянию на начало 2009 г. за счет социальноэкономических механизмов, координируемых и реализуемых государственными учреждениями «Соцуголь» и «ГУРШ», были решены все наиболее актуальные проблемы шахтерских семей, а также созданы условия стабильного функционирования социальных механизмов поддержки населения углепромышленных городов и поселков [11, с.7-8; 12, с. 5].

Таким образом, в ходе реструктуризации была создана государственная институциональная организационноэкономическая среда, обеспечивающая функционирование практически всех механизмов ее проведения, в том числе социально ориентированных.

Постепенное расширение полномочий региональных и местных органов власти позволило активнее привлекать бизнес к реализации социально значимых проектов, в том числе на основе развития институтов и механизмов государственно-частного партнерства (ГЧП) и муниципально-частного партнерства (МЧП). Работники предприятий угольной промышленности получили дополнительные формы поддержки за счет отраслевых соглашений и договоров о социальном партнерстве [13, с. 237]. Увеличивалось количество работников угольной отрасли, направленных на отдых в лечебнооздоровительные санатории и профилактории, стали проводиться спортивные соревнования среди угольных компаний и т.д. [14, с. 221]. Активнее других руководителей шахтерских территорий новые возможности использовал губернатор Кемеровской области А. Тулеев, что стало дополнительным фактором динамичного развития ведущего угольного бассейна [15, С. 215].

В Кузбассе впервые получила развитие практика заключения региональных соглашений о социальноэкономическом сотрудничестве областной администрации с крупными частными угольными компаниями, которая затем нашла широкое распространение и в других углепромышленных регионах. В этих соглашениях предусматриваются не только программно-целевые ме- роприятия по диверсификации и модернизации угольного и смежных производств, но и социально ориентированные мероприятия. Государственно-частное партнерство здесь последовательно развивается по уровням комплексности и масштабности конкретных экономических и социальных мероприятий [16, с. 58].

В качестве положительного примера институционализации территориально-отраслевой корпоративной социальной политики следует отметить создание на принципах ГЧП некоммерческой организации Фонд социально-экономической поддержки регионов «СУЭКРегионам», созданной в конце 2007 г. для разработки и реализации социальных и благотворительных программ AO «СУЭК» [17]. Кроме Кемеровской области деятельность Фонда осуществляется еще в шести регионах страны.

\section{ВЛИЯНИЕ ИНСТИТУЦИОНАЛИЗАЦИИ РОССИЙСКОЙ ЭКОНОМИКИ НА СТРУКТУРНЫЕ ПРЕОБРАЗОВАНИЯ В УГОЛЬНОЙ ОТРАСЛИ И НА УГЛЕПРОМЫШЛЕННЫХ ТЕРРИТОРИЯХ}

Параллельно с функционированием институциональной системы регулирования структурных преобразований в угольной отрасли и на углепромышленных территориях с 2005 г. на федеральном уровне началась массовая институционализация российской экономики в целях стимулирования региональных инновационных процессов и реализации инфраструктурных проектов с использованием механизмов ГЧП, в результате которой были созданы: Инвестиционный фонд РФ (2005 г.); особые экономические зоны (2005 г.); государственные корпорации «Внешэкономбанк» (2007 г.), «Российская корпорация нанотехнологий» (2007 г.), реорганизованная в 2011 г. в АО «Роснано», ГК «Фонд содействия реформированию ЖКХ» (2007 г.); зоны территориального развития (2011 г.); территории опережающего социальноэкономического развития (2014 г.); Фонд развития промышленности (2014 г.); Фонд развития моногородов (2014 г.) и др.

По аналогии с мировым опытом с 2006 г. в России начал внедряться новый инновационный институт технопарков и индустриальных парков, представляющий собой особую форму взаимодействия науки, производства и образования с целью стимулирования развития передовых технологий и наукоемкого бизнеса. Была развернута государственная программа «Создание в Российской Федерации технопарков в сфере высоких технологий» [18]. Кроме того, началось создание частных технопарков и индустриальных парков [19]. При этом только в одном углепромышленном регионе - в Кемеровской области действует с 2008 г. «Кузбасский технопарк» (входит в состав 12 технопарков, поддержанных Минкомсвязью России), среди резидентов которого пока только одно ОАО «Газпром добыча Кузнецк» реализует проект, связанный с угольной отраслью - добыча метана из угольных пластов на первоочередных площадях в Кузбассе [20].

Следует отметить, что, несмотря на некоторую стихийность формирования, институты развития заняли определенную нишу в национальной инновационной структу- 


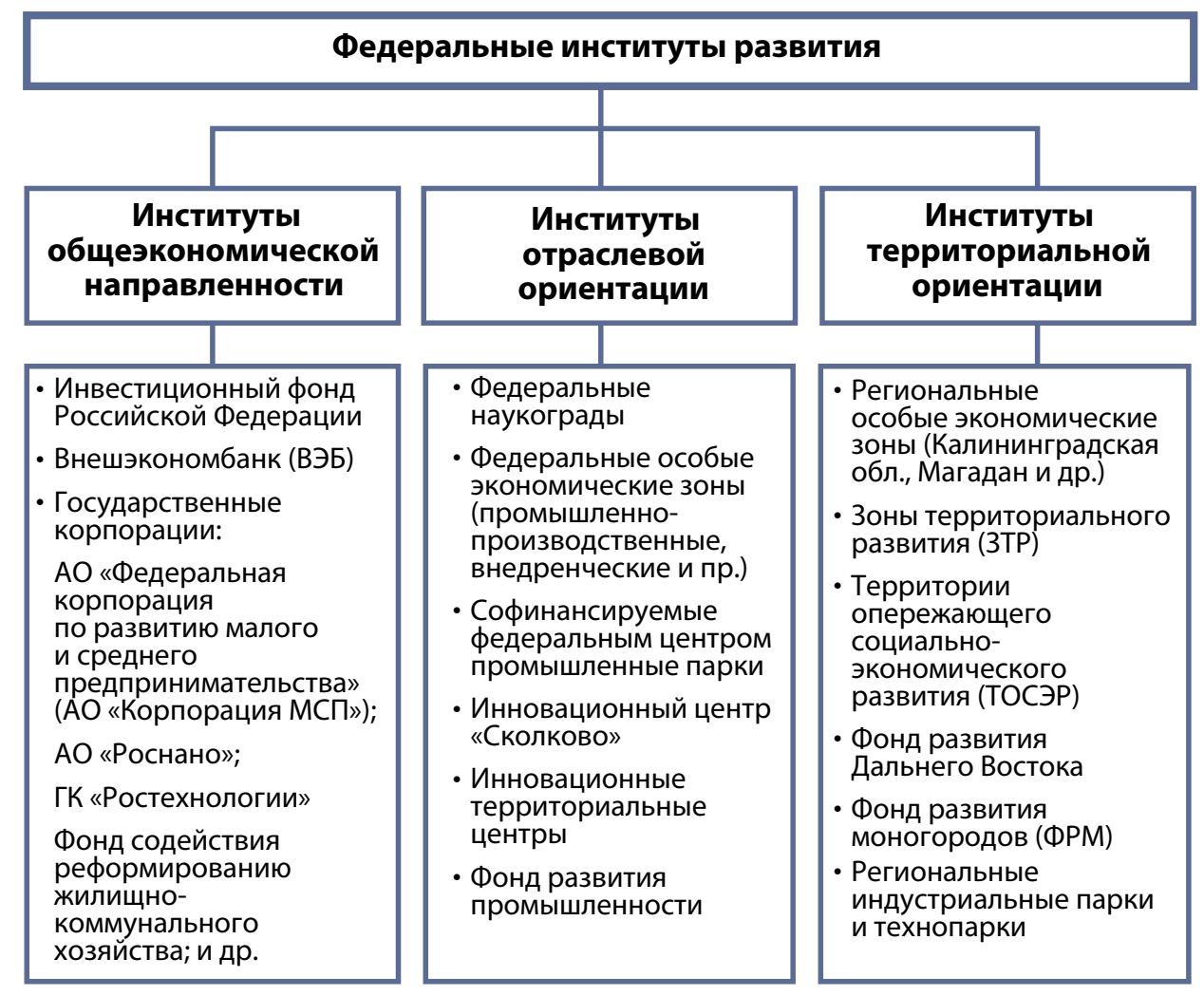

Федеральные институты развития, оказывающие влияние на регулирование структурных преобразований в угольной отрасли и на углепромышленных территориях России

ре и до сих пор доказывают свою состоятельность. Фактически сегодня можно выделить три уровня функционирования институтов развития в зависимости от того, кто является инициатором их создания: федеральные институты развития, федеральные институты развития на региональном уровне, региональные институты развития [21]. В свою очередь федеральные институты развития можно классифицировать как общеэкономические, отраслевые и территориальные (см. рисунок) [22, с. 14].

Экономический кризис 2008-2009 гг. больно затронул добывающие отрасли промышленности, в том числе и угольную. Несмотря на сложную финансовую ситуацию, Правительство РФ приняло ряд мер по поддержанию социально-экономической стабильности на углепромышленных территориях. В 2009-2011 гг. на федеральном и региональных уровнях был принят ряд специальных институциональных и методологических решений по поддержанию жизнедеятельности моногородов России, в том числе угольной специализации, когда по решению Правительства России при институциональной и финансовой поддержке государства и участии бизнес-структур начались разработка и реализация комплексных инвестиционных планов (КИП) модернизации моногородов на период до 2020 г.

Из шахтерских городов в качестве пилотных были определены Гуково, Ленинск-Кузнецкий и Прокопьевск, которые частично получили бюджетные средства на реализацию своих КИПов в 2010-2011 гг. через федеральные общеэкономические институты развития (Инвестиционный фонд РФ, Фонд содействия реформированию ЖКХ, Фонд развития промышленности). Средства в виде дотаций и кредитов предоставлялись субъектам РФ для реализации инвестиционных проектов по строительству, реконструкции и модернизации объектов коммунальной и инженерной инфраструктуры, необходимых для создания условий реализации на территории моногородов этих инвестиционных проектов. Кроме того, оказывалась господдержка моногородам через субсидии бюджетам субъектов РФ на конкурсной основе по линии Минэкономразвития России на поддержку малого и среднего предпринимательства, а по линии Федеральной службы по труду и занятости - на реализацию дополнительных мероприятий, направленных на снижение напряженности на рынке труда.

В этот период были также разработаны КИПы по городам: Междуреченск, Анжеро-Судженск, Белово, Киселевск, Осинники и др. Но государственная поддержка моногородов на основе финансирования комплексных инвестиционных планов не получила должного развития. Проблема заключалась в том, что разработка КИПов не регламентировалась какими-либо нормативными правовыми актами, кроме того, требования к КИПам по содержанию, срокам разработки и другим параметрам не учитывали существенных различий в ресурсах и возможностях моногородов, и, как следствие, только 49 городов из 327 получили господдержку [23, с. 153]. При этом реализация мероприятий, софинансируемых из федерального бюджета в 2010-2011 гг., по состоянию на 1 июля 2016 г. не была завершена в 11 моногородах [24, с. 7] .

Всего в рамках основных направлений антикризисных действий Правительства РФ в 2010-2011 гг. Минфин Рос- 
сии предоставил дотации на поддержку мер по обеспечению сбалансированности бюджетов субъектов РФ в рамках государственной поддержки реализации мероприятий КИПов и (или) бюджетных кредитов 41 субъекту РФ в сумме17165 млн руб., в том числе 2237,7 млн руб. углепромышленным территориям - Кемеровской области (г. Прокопьевск и г. Ленинск-Кузнецкий) и Ростовской области (г. Гуково) [25, с. 69-71].

К сожалению, из-за того, что часть средств в 2010-2011 гг. оказалась невостребованной регионами и была возвращена в федеральный бюджет в 2012 и 2013 гг., дополнительные средства на поддержку моногородов в федеральном бюджете уже не предусматривались.

В целом, институциональные преобразования в целях стимулирования региональных инновационных процессов и реализации инфраструктурных проектов с использованием государственной поддержки российских моногородов в период 2010-2013 гг., по мнению авторов, не оказали существенного влияния на изменение социальноэкономического положения и снижение уровня монозависимости в моногородах, включая территории угольной специализации.

С 2014 г. прямая господдержка моногородов осуществляется через негосударственную некоммерческую организацию «Фонд развития моногородов» на основе заключения соглашений с субъектами РФ о софинансировании расходов в целях реализации мероприятий по строительству и реконструкции объектов инфраструктуры, необходимых для реализации инвестиционных проектов в конкретном монопрофильном муниципальном образовании. В настоящее время такие соглашения имеются в Кемеровской и Ростовской областях, а также Хабаровском крае.

Однако, по мнению Счетной палаты Российской Федерации, целесообразно пересмотреть механизм предоставления субсидий из федерального бюджета на софинансирование расходов субъектов РФ на поддержку моногородов в части возможности предоставления данных субсидий непосредственно через Минэкономразвития России, что позволит эффективно осуществлять контроль за использованием субсидий и достижением целевых показателей их предоставления [24, с. 60].

С 2014 г. предусмотрена также мера поддержки моногородов в форме создания территории опережающего социально-экономического развития (ТОСЭР) в соответствии с Федеральным законом от 29.12.2014 № 473-Ф3 «О территориях опережающего социально-экономического развития в Российской Федерации». В соответствии с распоряжением Правительства РФ от 16 апреля 2015 г. № 668-р монопрофильные муниципальные образования разделены на три категории, к которым отнесены:

- снаиболее сложным социально-экономическим положением (категория 1) - 10 углепромышленных территорий, включая моногорода Анжеро-Судженск (Кемеровская обл.) и Гуково (Ростовская обл.), получившие статус ТОСЭР;

- с риском ухудшения социально-экономического положения (категория 2) - 20 углепромышленных территорий;
- со стабильной социально-экономической ситуацией (категория 3) - две углепромышленные территории Кузбасса (пос. Краснобродский и г. Новокузнецк).

Экономическое положение в моногородах Российской Федерации за период 2014-2016 гг. характеризуется следующими особенностями [24, с. 5; 25, с. 4]:

- больше всего моногородов в углепромышленной Кемеровской области - 24 моногорода, в Свердловской и Челябинской областях - 17 и 16 соответственно;

- наибольшее количество «кризисных» моногородов отмечается в углепромышленной Кемеровской области - 9 моногородов, в Челябинской области - 7, в Республике Карелия - 6 и Пермском крае - 6;

- количество моногородов с наиболее сложным социально-экономическим положением увеличилось с 75 до 100;

- в 71 моногороде уровень регистрируемой безработицы превышает среднероссийский показатель в два и более раз.

Как отмечается в Бюллетене Счетной палаты РФ [24, с. 56], в настоящее время оценить эффективность использования субсидий из федерального бюджета на реализацию мероприятий, направленных на формирование необходимых условий для создания новых рабочих мест и привлечение инвестиций в моногородах, практически не представляется возможным, поскольку ни данные Минэкономразвития России, ни данные «Фонда развития моногородов» и субъектов Российской Федерации и муниципальных образований не дают объективной информации. При этом, в целом, несмотря на финансовую поддержку моногородов со стороны государства, на сегодняшний день существует негативная динамика в сфере занятости их населения.

\section{ЗАКЛЮЧЕНИЕ}

Итак, в последнее десятилетие XX в. шел процесс формирования институциональной системы регулирования структурных преобразований в угольной отрасли и на углепромышленных территориях России. Одним из важнейших результатов этого процесса стало создание государственных учреждений «ГУРШ» и «СОЦУГОЛь» - организаций, сумевших объединить и реализовать на принципах социального и государственно-частного партнерства интересы всех участников территориально-отраслевых структурных преобразований и продолжающих свою деятельность на заключительном этапе реструктуризации. Успешные результаты развития угольной отрасли на рубеже веков $[26,27]$ позволили трансформировать и сориентировать институциональную систему регулирования структурных преобразований на реализацию задач конкурентоспособного и инновационного уровня. Однако слабым звеном современной институциональной системы остаются финансовые институты, через которые до сих пор не отработаны четкие и прозрачные механизмы доведения бюджетных средств государственной поддержки до конечных получателей на реализацию инвестиционных проектов по диверсификации экономики и программ социально-экономического развития углепромышленных территорий. В этой связи целесообраз- 
но использовать накопленный опыт институциональных взаимодействий в ходе реструктуризации угольной промышленности России, адаптировав его к современным социально-экономическим условиям.

\section{Список литературы}

1. Краснянский Г.Л. Реструктуризацию угольной промышленности России следует изучать в профильных вузах // Forbes. URL: http://www.forbes.ru/biznes/343035-georgiykrasnyanskiy-restrukturizaciyu-ugolnoy-promyshlennostirossii-sleduet-izuchat (дата обращения: 15.01.2018).

2. День шахтера (реструктуризация угольной промышленности глазами участников и журналистов). М.: 2004. $132 \mathrm{c}$.

3. Угольная промышленность. Социально-экономический словарь-справочник. / Н.И. Гаркавенко, А.Н. Гаркавенко, В.Н. Попов и др. М.: ООО «Редакция журнала «Уголь», 2007. 514 с.

4. Постановление Правительства РФ от 03.09.1998 № 1026 «О внесении изменений и дополнений в Постановление Правительства Российской Федерации от 3 декабря 1997 г. № 1523 «О государственном финансировании мероприятий по реструктуризации угольной промышленности». URL: http://legalacts.ru/doc/postanovlenie-pravitelstva-rf-ot03091998-n-1026/ (дата обращения: 15.01.2018).

5. Рожков А.А., Анистратов М.К., Фролов А.А. Трансформация социально-экономических механизмов структурных преобразований в угольной промышленности России // Горная промышленность. 2015. № 5. С. 36-42.

6. «Рельсовые войны» стали историей // Искра (Инта, Республика Коми). 10 апреля 1999.

7. Проблемы и перспективы развития угольной промышленности. Федеральный справочник. Топливноэнергетический комплекс России [Электронный ресурс]. URL: http://federalbook.ru/files/FS/Soderjanie/FS-7/IV/ Problemi\%20i\%20perspektivi.pdf (дата обращения: 15.01.2018).

8. Указ Президента РФ от 9 марта 2004 г. № 314 «О системе и структуре федеральных органов исполнительной власти». URL: http://base.garant.ru/186816/\#friends (дата обращения: 15.01.2018).

9. Постановление Правительства РФ от 16 апреля 2004 г. № 215 «Обупорядочении состава координационных, совещательных, иных органов и групп, образованных Правительством Российской Федерации». URL: https://normativ. kontur.ru/document?moduleld=1\&documentld=99516 (дата обращения: 15.01.2018).

10. Указ Президента РФ от 12 мая 2008 г. № 724 «Вопросы системы и структуры федеральных органов исполнительной власти». URL: http://base.garant.ru/12160263/ (дата обращения: 15.01.2018).

11. Интервью с директором ГУ «Соцуголь», доктором экономических наук, профессором А.А. Рожковым // Уголь. 2009, № 3. C. 7-12. URL: http://www.ugolinfo.ru/Free/032009. pdf (дата обращения: 15.01.2018).

12. Агапов А.Е. Анализ выполнения работ по реализации программы ликвидации особо убыточных шахт и разрезов в 2008 году // Уголь. 2009, № 3. С. 3-6. URL: http://www. ugolinfo.ru/Free/032009.pdf (дата обращения: 15.01.2018).

13. Буфина Н.Э. Развитие системы социального партнерства на угольных предприятиях Кузбасса в XXIв. // Интел- лектуальный и индустриальный потенциал регионов России. Кемерово, 2012. С. 237-243.

14. Бирюкова О.В. Реструктуризация угольной промышленности Кузбасса в середине 1980-х - начале 2000-х гг. (на примере г. Кемерово) // Интеллектуальный и индустриальный потенциал регионов России. Кемерово, 2012. C. 217-222.

15. Harte S., Grävingholt J., Pleines H., Schröder $\mathrm{H}-\mathrm{H}$. Geschäfte mit der Macht. Bremen, 2003. 383 p.

16. Пяткин А.М., Рожков А.А. Государственно-частное партнерство в жизнедеятельности углепромышленных моногородов //Уголь. 2013. № 6. С. 58-63. URL: http://www. ugolinfo.ru/Free/062013.pdf (дата обращения: 15.01.2018).

17. Некоммерческая организация «Фонд социальноэкономической поддержки регионов «СУЭК - РЕГИОНАМ». URL: http://fond.suek.ru/ (дата обращения: 15.01.2018).

18. Комплексная программа «Создание в Российской Федерации технопарков в сфере высоких технологий» (Одобрена распоряжением Правительства РФ от 10 марта 2006 г. № 328-p). URL: http://minsvyaz.ru/ru/documents/3269/ (дата обращения: 15.01.2018).

19. Индустриальные парки и технопарки России. URL: http://russiaindustrialpark.ru/tehnopark_catalog_ perecheny_spisok_russia (дата обращения: 15.01.2018).

20. АО «Кузбасский технопарк». URL: http://technopark42. ru/departments/park/rezidents-technopark (дата обращения: 15.01.2018).

21. Институты развития России: ретроспектива формирования. URL: http://kapital-rus.ru/articles/article/instituty_ razvitiya_rossii_retrospektiva_formirovaniya/ (дата обращения: 15.01.2018).

22. Научный доклад: институты развития как инструмент региональной политики. М.: ФГБУН «Институт экономики PAН», 2015. С. 14.

23. Петрина О.А. Государственная поддержка моногородов в России // Вестник Государственного университета управления. 2015. № 6. С. 151-156.

24. Агапцов С.А., Перчян А.В., Росляк Ю.В. Сводный отчет о результатах контрольного мероприятия «Проверка эффективности использования средств федерального бюджета, направленных в некоммерческую организацию «Фонд развития моногородов» в 2014-2016 гг.» // Бюллетень Счетной палаты Российской Федерации. 2017. № 3. C. 3-67.

25. Отчет о результатах экспертно-аналитического мероприятия «Анализ результативности мер, принимаемых органами государственной власти по поддержке моногородов» (утвержден Коллегией Счетной палаты Российской Федерации, протокол от 7 апреля 2017 г. № 19K (1164, п.1). URL: http://komitet4.km.duma.gov.ru/ Sostoyavshiesya-meropriyatiya/item/12870343/ (дата обращения: 15.01.2018).

26. Яновский А.Б. Основные тенденции и перспективы развития угольной промышленности России //Уголь. 2017. № 8. C.10-14. doi: 10.18796/0041-5790-2017-8-10-14. URL: http://www.ugolinfo.ru/Free/082017.pdf (дата обращения: 15.01.2018).

27. Таразанов И.Г.Итоги работы угольной промышленности России за январь-сентябрь 2017 года // Уголь. 2018. № 1. C. 18-32. doi: 10.18796/0041-5790-2018-1-18-32/ 
UDC 338.45:331.96:622.33(470):65.016.8 @ A.A. Rozhkov, I.S. Solovenko, 2018

\title{
Title \\ FORMATION AND TRANSFORMATION OF THE INSTITUTIONAL SYSTEM FOR THE RUSSIAN COAL INDUSTRY AND COAL PROVINCES STRUCTURAL TRANSFORMATIONS MANAGEMENT
}

\author{
DOI: http://dx.doi.org/10.18796/0041-5790-2018-2-40-47
}

\section{Authors}

Rozhkov A.A.' , Solovenko I.S. ${ }^{2}$

"National University of Science and Technology "MISIS" (NUST "MISIS"), Moscow, 119049, Russian Federation

${ }^{2}$ Yurginsky Institute of Technology (branch) of FSAEI HE "National Research Tomsk Polytechnic University", Yurga, 652055, Russian Federation

\section{Authors' Information}

Rozhkov A.A., Doctor of Economic Sciences, Professor, Institute of Economics and Management of Industrial Enterprises, tel.: +7 (499) 230-24-78,

e-mail: aarozhkov@mail.ru

Solovenko I.S., PhD (History), Assistant Professor, tel.: +7 (38451) 7-77-62, e-mail: solovenko71@mail.ru

\section{Abstract}

In 1997 two state institutions - "GURSH" and "SOTSUGOL"' (currently FSBI) were established by the directive of RF Government no.1462 "On coal industry management improvement"; these institutions practical activities started twenty years ago, in February 1998, and until now they remain the corner stones of the institutional system for coal provinces structural reorganization. In this respect it is sensible to analyze the institutional system historical experience and transformation during coal industry reorganization and state support of the mono-cities, including coal industry associated cities.

Figures:

Fig. Federal Institutes of Development, having effect on the Russian coal industry coal provinces reorganization management

\section{Keywords}

Russian Federation, Institutional system, Reorganizations, Coal industry, Coal provinces, Mono-cities.

\section{References}

1. Krasniansky G.L. Restrukturizatsiyu ugolnoy promyshlennosti Rossii sleduet izuchat v profilnyh vuzah [Russian coal industry reorganization shall be studied in the specialized high schools]. Forbes. Available at: http://www.forbes.ru/biznes/343035-georgiykrasnyanskiy-restrukturizaciyu-ugolnoy-promyshlennosti-rossii-sleduet-izuchat (accessed 15.01.2018).

2. Den shahtera (restrukturizatsiya ugolnoy promyshlennostiglazamiuchastnikovizhurnalistov) [Miner's Day (coal industry reorganization through the eyes of participants and journalists)]. Moscow, 2004, 132 p.

3. Garkavenko N.I., Garkavenko A.N., Popov V.N. et al. Ugolnaya promyshlennost Sotsialno-ekonomicheskiy slovar-spravochnik. [Coal industry. Social-economic glossary - reference book]. Moscow, Ugol' Journal Edition LLC, 2007, 514 p.

4. Postanovlenie Pravitelstva RF ot 03.09.1998 N 1026 "O vnesenii izmeneniy idopolneniy v Postanovlenie Pravitelstva Rossiyskoy Federatsii ot 3 dekabrya 1997 goda N 1523 "O gosudarstvennom finansirovanii meropriyatiy po restrukturizatsii ugolnoy promysh lennosti". [Decree of RF Government No. 1523 dated December 3, 1997 "On federal financing of the coal industry reorganization activities"]. Available at: http://legalacts ru/doc/postanovlenie-pravitelstva-rf-ot-03091998-n-1026/ (accessed 15.01.2018). 5. Rozhkov A.A., Anistratov M.K. \& Frolov A.A. Transformatsiya sotsialno-ekonomicheskih mekhanizmov strukturnyh preobrazovaniy $v$ ugolnoy promyshlennosti Rossi [Transformation of the Russian coal industry restructuring social-economic mechanisms]. Gornaya Promyshlennost - Mining Industry, 2015, No. 5, pp. 36-42.

6. Relsovye voyny stali istoriey [Rail battles became history]. Iskra (Inta, Republic of Komi), April, 10, 1999.

7. Problemy i perspektivy razvitiya ugolnoy promyshlennosti. Federalnyy spravochnik Toplivno-energeticheskiy kompleks Rossii [Coal industry problems and prospects. Federal reference book. Fuel and energy complex of Russia]. Web-resource. Available at: http://federalbook.ru/files/FS/Soderjanie/FS-7/IV/Problemi\%20i\%20perspektivi.pdf (accessed 15.01.2018).

8. Ukaz Prezidenta RF ot 9 Marta 2004 goda N 314 "O sisteme i strukture federalnyh organov ispolnitelnoy vlasti" [RF President Decree No. 314 dated March 9, 2004 "On executive federal agencies system and structure"]. Available at: http://base.garant. ru/186816/\#friends (accessed 15.01.2018).

9. Postanovlenie Pravitelstva RF ot 16 Aprelya 2004 goda N 215 "Ob uporyadocheni sostava koordinatsionny soveshchatelny iny horganovigrupp obrazovannyh Pravitelstvom Rossiyskoy Federatsii" [RF Government resolution No. 215 dated April 16, 2004 "On regulation of coordination, consultative and other Russian Federation Government formed bodies and groups"]. Available at: https://normativ.kontur.ru/docume nt?moduleld=1\&documentld=99516 (accessed 15.01.2018).
10. Ukaz Prezidenta RF ot 12 Maya 2008 goda N 724 "Voprosy sistemy i struktury federalnyh organov ispolnitelnoy vlasti" [RF President Decree No. 724 dated May 12, 2008 "On executive federal bodies system and structure aspects"]. Available at: http://base. garant.ru/12160263/ (accessed 15.01.2018).

11. Intervyu s direktorom GU "Sotsugol" doktorom ekonomicheskih nauk, professorom A.A. Rozhkovym [Interview with Director GU "Sotsugol", Doctor of Economic Sciences, Professor Rozhkov A.A.]. Ugol' - Russian Coal Journal, 2009, No. 3, pp. 7-12. Available at: http://www.ugolinfo.ru/Free/032009.pdf (accessed 15.01.2018).

12. Agapov A.E. Analiz vypolneniya rabot po realizatsii programmy likvidatsii osobo ubytochnyh shaht i razrezov $v 2008$ godu [The analysis of performance of work on realization of the program of liquidation of especially unprofi table mines and openpit mines in 2008 year]. Ugol' - Russian Coal Journal, 2009, No. 3, pp. 3-6. Available at: http://www.ugolinfo.ru/Free/032009.pdf (accessed 15.01.2018).

13. Bufina N.E. Razvitie sistemy sotsialnogo partnerstva na ugolnyh predpriyatiyah Kuzbassa vXXI veke [Social partnership system development in Kuzbass coal enterprises in XXI century]. Russian regions intellectual and industrial potential. Kemerovo, 2012, pp. 237-243.

14. Birykova O.V. Restrukturizatsiya ugolnoy promyshlennosti Kuzbassa vseredine 1980-h nachale 2000-h godov (na primere Kemerovo) [Kuzbass coal industry reorganization in the middle of 1980 s - beginning of 2000-s (with reference to Kemerovo)]. Russian regions intellectual and industrial potential. Kemerovo, 2012, pp.. 217-222.

15. HarteS., Grävingholt J., Pleines H., Schröder H-H. Geschäfte mit der Macht. Bremen, 2003. 383 p.

16. Pyatkin A.M. \& Rozhkov A.A. Gosudarstvenno-chastnoe partnerstvo v zhiznedeyatel'nosti uglepromyshlennykh monogorodov [Partnership between the state and the business in the life of coal one-industry towns]. Ugol' - Russian Coal Journal, 2013, No. 6, pp. 58-63. Available at: http://www.ugolinfo.ru/Free/062013. pdf (accessed 15.01.2018).

17. Nekommercheskaya organizatsiya Fond sotsialno-ekonomicheskoy podderzhki regionov "SUEK - REGIONAM"[Non-profit company"Fund of regions social and economic support "SUEK - REGIONS"]. Avaiable at: http://fond.suek.ru/ (accessed: 15.01.2018). 18. Kompleksnaya programma "Sozdanie v Rossiyskoy Federatsii tekhnoparkov v sfere vysokih tekhnologiy" (Odobrena rasporyazheniem Pravitelstva RF ot 10 Marta 2006 goda N 328-r [Comprehensive program "High technoparks establishing in the Russian Federation" (endorsed by the RF Government Decree No. 328-r dated March 10, 2006)]. Available at: http://minsvyaz.ru/ru/documents/3269/ (accessed 15.01.2018). 19. Industrialnye parki i tekhnoparki Rossii [Industrial parks and technoparks in Russia]. Available at: http://russiaindustrialpark.ru/tehnopark_catalog_perecheny_spisok_russia (accessed 15.01.2018).

20. AO Kuzbasskiy tekhnopark ["Kuzbass tecnopark" JSC]. Available at: http://technopark42.ru/departments/park/rezidents-technopark (accessed 15.01.2018).

21. Instituty razvitiya Rossii: retrospektiva formirovaniya [Russian Institutes of development. Organization history]. Available at: http://kapital-rus.ru/articles/article/instituty_razvitiya_rossii_retrospektiva_formirovaniya/ (accessed 15.01.2018).

22. Nauchnyy doklad: instituty razvitiya kak instrument regionalnoy politiki [Scientific report: institutes of development as regional policy tool]. Moscow, FGBUN “Institut ekonomiki RAN" Publ., 2015, p. 14.

23. Petrina O.A. Gosudarstvennaya podderzhka monogorodov v Rossii [State support for mono-cities in Russia"]. Vestnik Gosudarstvennogo universiteta upravleniy - Newsletter of the State Management University, 2015, No. 6, pp. 151-156.

24. Agaptsov S.A., Perchyan A.V. \& Rosliak Yu.V. Svodnyy otchet o rezultatah kontrolnogomeropriyatiya "Proverka effektivnosti ispolzovaniya sredstv federalnogo byudzheta napravlennyh vnekommercheskuyu organizatsiyu "Fond razvitiya monogorodovv 2014$2016 \mathrm{gg}$. [Summary report on results of the audit activity "Audit of the expenditure efficiency of the federal budget funds, allocated to the non-profit company "Monocities development fund" in 2014-2016]. Audit Chamber of the Russian Federation Bulletin, 2017, No. 3, pp. 3-67.

25. Otcheto rezultatahekspertno-analiticheskogomeropriyatiya "Analiz rezultativnostimer prinimaemyh organamigosudarstvennoy vlastipo podderzhke monogorodov" (utverzhden Kollegiey Schetnoy palaty Rossiyskoy Federatsii, protokolot 7 Aprelya 2017 goda N $19 \mathrm{~K}$ (1164), punkt 1) [Report on expert-analytical activity results "Analysis of the effectiveness of the actions, performed by the state government bodies for mono-cities support" (endorsed by the Board of the Audit Chamber of the Russian Federation, protocol No. 19K (1164), dated April 7, 2017, item 1]. Available at: http://komitet4.km.duma.gov.ru/ Sostoyavshiesya-meropriyatiya/item/12870343/ (accessed 15.01.2018).

26. Yanovsky A.B. Main trends and prospects of the coal industry development in Russia. Ugol' - Russian Coal Journal, 2017, No. 8, pp. 10-14. doi: 10.18796/0041-5790-20178-10-14. Available at: http://www.ugolinfo.ru/Free/082017.pdf (accessed 15.01.2018). 27. Tarazanov I.G. Russia's coal industry performance for January - September, 2017. Ugol' - Russian Coal Journal, 2018, No. 1, pp. 18-32. doi: 10.18796/0041-5790-2018-1-18-32. 


\section{Ретроспективная и прогнозная оценки эффективности технологического развития угольной промышленности России}

DOI: http://dx.doi.org/10.18796/0041-5790-2018-2-48-53

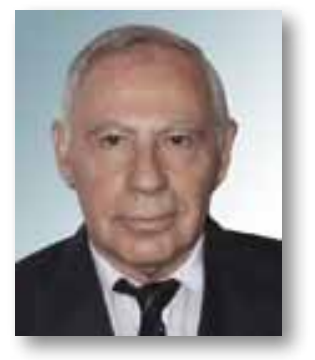

ВоСКоБойник Михаил Петрович

Доктор экон. наук,

117186, г. Москва, Россия,

тел.: +7 (495) 610-83-20,

e-mail:mivoskob@mail.ru

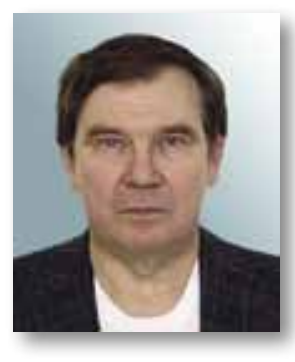

РОжков Анатолий Алексеевич
Доктор экон. наук,
профессор НИТУ «МИСиС»,
председатель совета директоров
AO «осинформуголь»,
119049, г. Москва, Россия,
mел.: +7 (499) 236-81-55,
e-mail: aarozhkov@mail.ru

Приведен ретроспективный анализ за период 2012-2016 гг.и выполнены прогнозные расчеты до 2035 г. технологического развития угольной промышленности России с учетом изменения важнейших показателей, отражающих уровень технологического состояния отрасли. Факторная прогнозная оценка технологического развития угольной промышленности дана с использованием расчетов по разработанной производственно-финансовой математической модели прогнозирования технологического развития в трех качественно отличных сценариях - инерционном, умеренного технологического развития, инновационном. Определены условия роста производительности труда в угольной промышленности за счет интенсивных факторов в долгосрочной перспективе. Ключевые слова: технологическое развитие, производительность труда, фондоотдача и фондовооруженность труда, темп роста, инвестичии в основной капитал, экстенсивные и интенсивные факторы, сценарии: инерционный, умеренного технологического развития и инновачионный.

\section{ВВЕДЕНИЕ}

Под технологическим развитием угольной промышленности понимается развитие производственной деятельности на базе использования новой техники и технологий, высококвалифицированных кадров и технологических инноваций, которое в долгосрочной перспективе призвано обеспечить конкурентоспособность угольной отрасли, по- вышение уровня жизни ее работников и улучшение качества использования человеческого потенциала в целом. Применительно к анализу и оценке уровня технологического развития угольной промышленности предлагаются следующие основные показатели:

- производительность труда одного работника в основном производстве; фондоотдача (отношение объема добычи угля к стоимости основных фондов);

- фондовооруженность труда (отношение стоимости основных фондов к численности работников в основном производстве);

- доля инвестиций, направленных на реконструкцию и модернизацию в общем объеме инвестиций в основной капитал;

- доля инвестиций в машины и оборудование в общем объеме инвестиций в основной капитал. При этом следует отметить, что данные показатели корреспондируются с системой показателей Росстата для статистической оценки уровня технологического развития отраслей экономики [1].

Ретроспективный анализ производительности труда в угольной промышленности России за последние пять лет показывает ее значительно более низкий уровень по сравнению сведущими угледобывающими странами мира, что связано как с более сложными горно-геологическими условиями добычи угля, так и с техническим уровнем оборудования и слабым его обновлением на новое, более э $\phi$ фективное.

По расчетам Института энергетических исследований РАН (ИНЭИ РАН), средняя производительность труда в угольной промышленности России в 5-9 раз ниже, чем в развитых угледобывающих странах мира:

- при подземной добыче угля ниже, чем в США, в 5,9 раза; чем в ЮАР - в пять раз; чем в Австралии - в 3,9 раза; чем в Китае - в 3,7 раза;

- при открытой добыче угля ниже, чем в Австралии, в 9,3 раза; чем в США - в восемь раз; чем в ЮАР - в 4,5 раза; чем в Китае - в 4,3 раза.

Многие угольные компании оснащены горношахтным и горнотранспортным оборудованием, которое по многим видам и по своим техническим параметрам значительно отстает от новых зарубежных аналогов.

Ввод активной части основных фондов в отрасли за последние годы в среднем практически не превышал 3-3,5\% в год, что является весьма низким по сравнению с развитыми странами мира, в которых указанный показатель редко опускается ниже значения 10\%. 
Структура инвестиций в основной капитал угольной промышленности России в период 2012-2016 гг., \%

\begin{tabular}{|c|c|c|c|c|c|c|}
\hline Показатели & 2012 r. & 2013 r. & 2014 r. & 2015 r. & 2016 r. & $\begin{array}{c}2012-2016 \text { rг. } \\
\text { (в среднем) }\end{array}$ \\
\hline Доля затрат на перевооружение и реконструкцию & 34,7 & 30,7 & 41,2 & 32,9 & 45,5 & 37 \\
\hline $\begin{array}{l}\text { Из них: } \\
\text { - доля затрат на приобретение машин, оборудования } \\
\text { и транспортных средств }\end{array}$ & 27,1 & 24 & 26,6 & 24 & 39,5 & 28,2 \\
\hline Прочие инвестиции в основной капитал & 65,3 & 69,3 & 58,8 & 67,1 & 54,5 & 63 \\
\hline
\end{tabular}

Источник: ФГБУ «ЦДУТЭК»

В инвестициях в основной капитал доля затрат на техническое перевооружение и реконструкцию в среднем за 2012-2016 гг. составила только 36,4\%, в том числе доля затрат на приобретение машин, оборудования и транспортных средств - 28\% (табл. 1).

Рост производительности труда в 2012-2016 гг. происходил в угольной промышленности России только за счет роста фондовооруженности труда при снижении фондоотдачи (кроме 2016 г.). Производительность труда за этот период увеличилась на 29,2\% и обеспечивалась ростом фондовооруженности труда на 78,8\% при снижении фондоотдачи на $27,8 \%$.

Влияние на производительность труда фондовооруженности труда и фондоотдачи по годам пятилетия в неизменных ценах приведено на рис.1.

Анализ технологического развития добычи угля показывает, что за последние несколько десятилетий в угольной промышленности не внедрено ни одной принципиально новой системы разработки месторождений угля, а происходит лишь эволюционное совершенствование существующей техники и технологий.

Современная техника и технология ведения подземных горных работ исчерпали резервы повышения производительности и интенсивности труда, снижения уровня ручного труда и безопасности. В рамках традиционной технологии добычи угля эти проблемы уже не решаются.
Открытый способ разработки обладает большими возможностями повышения производительности и интенсивности труда в связи с применением все увеличивающейся единичной мощности техники для экскавации и транспортирования горной массы. Однако уже и здесь достигнут определенный предел роста мощности оборудования, связанный не только с возможностями машиностроения, но и с технологическими особенностями горной промышленности.

В связи с этим возникает необходимость перехода к новому технологическому отраслевому укладу развития на основе инновационных технологий, составляющих технологическую платформу промышленной стратегии «Индустрия-4.0» (четвертой промышленной революции). При этом основные сценарии технологического развития угольной промышленности в долгосрочной перспективе будут определяться скоростью перехода к новому технологическому укладу.

В зависимости от стратегических ориентиров по возможным сценариям добычи угля и производительности труда на период до 2035 г. авторами выделяются три качественно различных сценария при переходе отрасли к новому технологическому укладу - инерционный, умеренного технологического развития и инновационный (табл. 2).

Сценарий инерционного технологического развития основывается на сохранении существующего научнотехнологического потенциала угольной отрасли и отечественного горного машиностроения в рамках третьего-четвертого технологических укладов. Развитие угольной промышленности базируется на ориентирах существующих технологических платформ (ТП) - ТП «Твердых полезных ископаемых» и ТП «Экологически чистая тепловая энергетика высокой эффективности» $[2,3]$.

Сценарий инновационного развития предполагает широкомасштабное использование мировых трендов технологического развития при реализации направлений пятого и шестого технологических укладов с внедрением элементов промышленной стратегии «Индустрия-4.0». В качестве базиса реализации данного сценария, кроме действующих технологических платформ, должны быть разработаны и реализованы технологические платформы принципиально нового инновационного уровня. 
Стратегические ориентиры по возможным сценариям добычи угля и производительности труда на период до 2035 г.

\begin{tabular}{|c|c|c|c|c|c|c|}
\hline Сценарии & Стратегические ориентиры & 2020 r. & 2025 r. & 2030 r. & 2035 r. & 2035 г./2015 г., \% \\
\hline \multirow[t]{2}{*}{ Инерционный } & Добыча угля, млн т & 390 & 400 & 410 & 450 & 120,3 \\
\hline & $\begin{array}{l}\text { Среднемесячная производительность } \\
\text { труда одного работника в основном } \\
\text { производстве, т }\end{array}$ & 316 & 390 & 499 & 653 & В три раза \\
\hline \multirow{2}{*}{$\begin{array}{l}\text { Умеренного } \\
\text { технологического } \\
\text { развития }\end{array}$} & Добыча угля, млн т & 400 & 420 & 430 & 500 & 133,7 \\
\hline & $\begin{array}{l}\text { Среднемесячная производительность } \\
\text { труда одного работника в основном } \\
\text { производстве, т }\end{array}$ & 320 & 425 & 585 & 867 & В четыре раза \\
\hline \multirow[t]{2}{*}{ Инновационный } & Добыча угля, млн т & 420 & 450 & 480 & 520 & 139 \\
\hline & $\begin{array}{l}\text { Среднемесячная производительность } \\
\text { труда одного работника в основном } \\
\text { производстве, т }\end{array}$ & 325 & 447 & 673 & 1081 & В пять раз \\
\hline
\end{tabular}

Сценарий умеренного технологического развития является промежуточным в части достижения стратегических ориентиров технологического развития угольной промышленности России.

Расчеты по оценке эффективности технологического развития отрасли до 2035 г. по приведенным сценариям были проведены с использованием разработанной производственно-финансовой математической модели прогнозирования технологического развития угольной промышленности, которая дает возможность определить уровни показателей, необходимые для достижения в отрасли прогнозируемой производительности труда, соответствующей уровню ведущих угледобывающих стран мира. Расчеты проводились в ценах 2012 г. для исключения влияния ценностного фактора, выявления истинной эффективности технического состояния отрасли в перспективе и возможности сравнения с периодом 2012-2016 гг.

Для реализации сценария инерционного развития, по которому рост производительности труда должен возрасти в три раза, необходимо:

- повысить долю обновления основных производственных средств с 3,5\% в 2016 г. до 7,7\% в 2035 г.;

- долю роста фондоотдачи вводимых основных фондов в основном производстве в темпе роста производительности труда увеличить к 2035 г. до 50\% (в период 2012-2016 гг. снижение фондоотдачи оказывало отрицательное влияние на рост производительности труда);

- фондоотдачу вводимых основных фондов в основном производстве поднять с 0,931 т/тыс. руб. в 2016 г. до 1,515 т/тыс. руб. в 2035 г., то есть в 1,55 раза;

- фондовооруженность труда в основном производстве увеличить в 2,55 раза;

- долю инвестиций, направляемых на реконструкцию и модернизацию, в общем объеме инвестиций в основной капитал повысить с 45,5\% в 2016 г. до 55,8\% в 2035 г.;

- долю затрат на приобретение машин, оборудования и транспортных средств в общем объеме инвестиций в основной капитал увеличить с 39,5\% в 2016 г. до 62\% в 2035 г.

При этих условиях технологического развития отрасли рост фондовооруженности труда в 2,5 раза и рост фондоотдачи на 16,1\% позволят увеличить производительность труда в 2035 г. по сравнению с 2015 г. в три раза при росте добычи угля на 20,3\%.
Зависимости темпов изменения основных показателей технологического развития угольной промышленности при реализации инерционного сценария в период до 2035 г. (в неизменных ценах) приведены на рис. 2.

Реализация сценария умеренного технологического развития, по которому рост производительности труда должен возрасти в четыре раза, вызывает необходимость:

- повысить долю обновления основных производственных средств с 3,5\% в 2016 г. до 10,1\% в 2035 г.;

- долю роста фондоотдачи вводимых основных фондов в основном производстве в темпе роста производительности труда увеличить к 2035 г. до 60\%;

- фондоотдачу вводимых основных фондов в основном производстве повысить до 1,515 т/тыс. руб., то есть в 1,85 раза;

- фондовооруженность труда в основном производстве увеличить в 3,2 раза;

- долю инвестиций, направляемых на реконструкцию и модернизацию, в общем объеме инвестиций в основной капитал повысить до 62\% в 2035 г.;

- долю затрат на приобретение машин, оборудования и транспортных средств в общем объеме инвестиций в основной капитал увеличить до 88\% в 2035 г.

При этих условиях технологического развития отрасли рост фондовооруженности труда в 3,2 раза и рост фондоотдачи на 21,9\% позволят увеличить производительность труда в 2035 г. по сравнению с 2015 г. в четыре раза при росте добычи угля на 33,7\%.

Зависимости темпов изменения основных показателей технологического развития угольной промышленности при реализации умеренного сценария в период до 2035 г. (в неизменных ценах) приведены на рис. 3.

Для реализации сценария инновационного развития, по которому рост производительности труда должен возрасти в пять раз, необходимо:

- повысить долю обновления основных производственных средств с 3,5\% в 2016 г. до 12,6\% в 2035 г.;

- долю роста фондоотдачи вводимых основных фондов в основном производстве в темпе роста производительности труда увеличить к 2035 г. до 70\%;

- фондоотдачу вводимых основных фондов в основном производстве увеличить до 2,286 т/тыс. руб., то есть в 2,3 раза;

- фондовооруженность труда в основном производстве увеличить в 3,9 раза; 


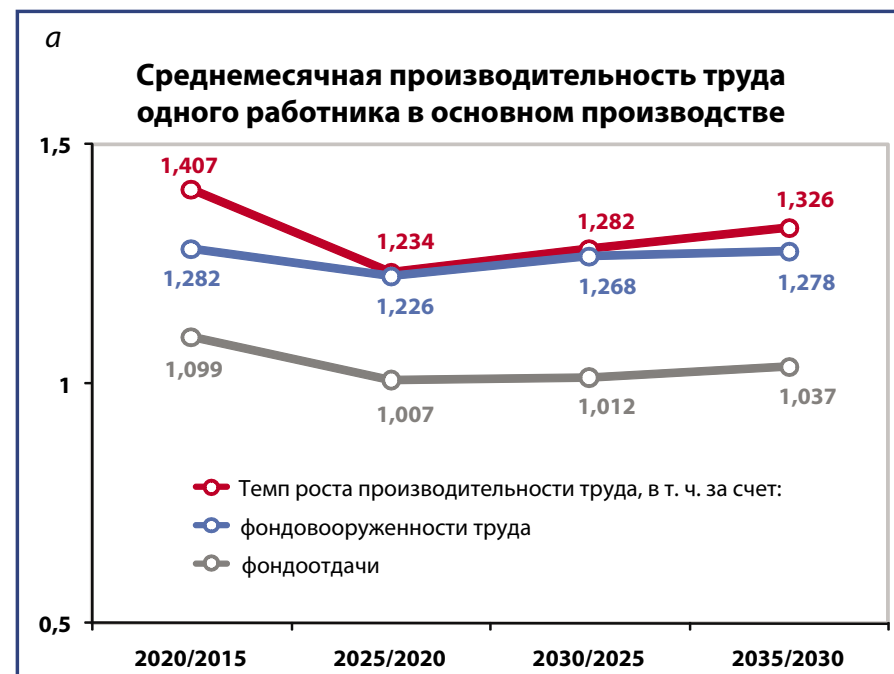

одного работника в основном производстве

B

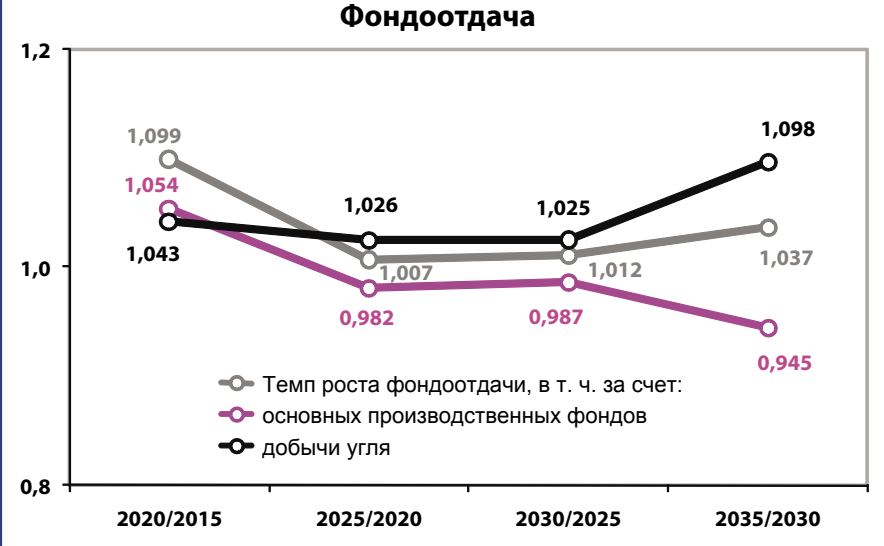

$a$

\section{Среднемесячная производительность труда} одного работника в основном производстве

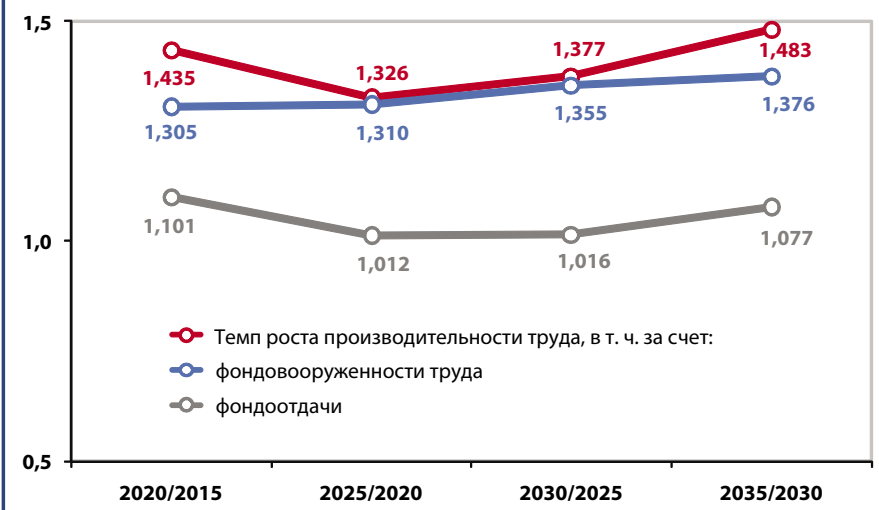

B

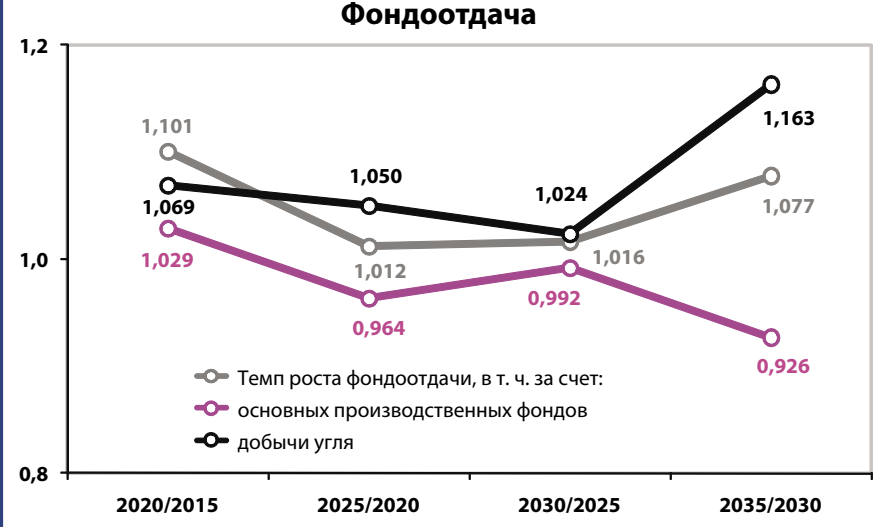

Фондовооруженность труда

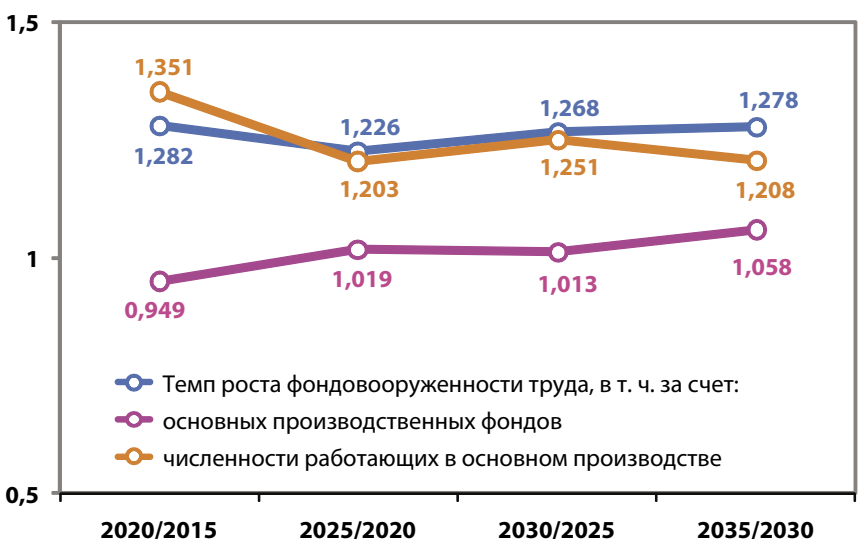

Источник: расчеты авторов

Pис. 2. Зависимости темпов изменения основных показателей технологического развития угольной промышленности при реализации инерционного сиенария в период до 2035 г. (в неизменных ценах 2012 г.)

Fig. 2. Coal industry technological development indicators variability rate under inertia scenario implementation until 2035 (stable prices, 2012)

\section{6}

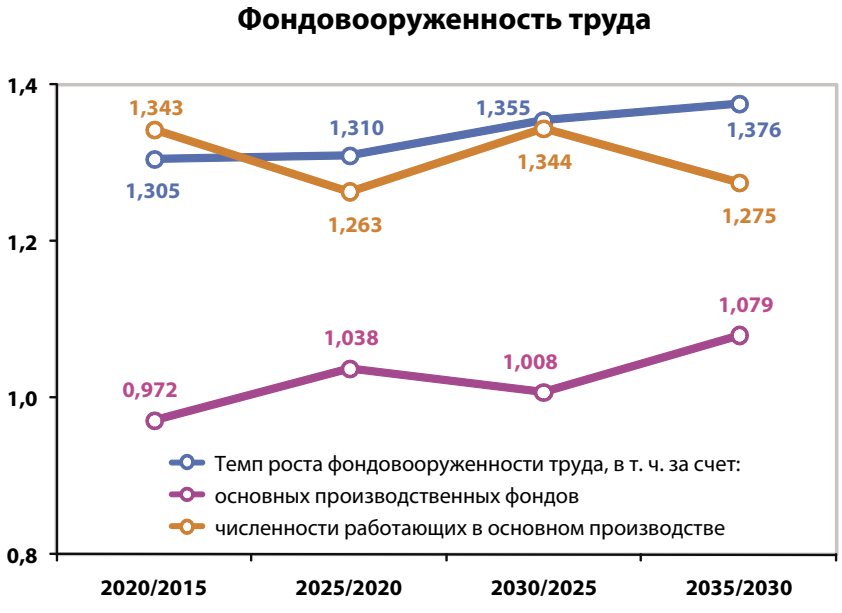

Источник: расчеты авторов

Рис. 3. Зависимости темпов изменения основных показателей технологического развития угольной промышленности при реализации умеренного сценария в период до 2035 г. (в неизменных ценах 2012 г.)

Fig. 3. Coal industry technological development indicators variability rate under moderate development scenario implementation until 2035 (stable prices, 2012) 
$a$

Среднемесячная производительность труда одного работника в основном производстве

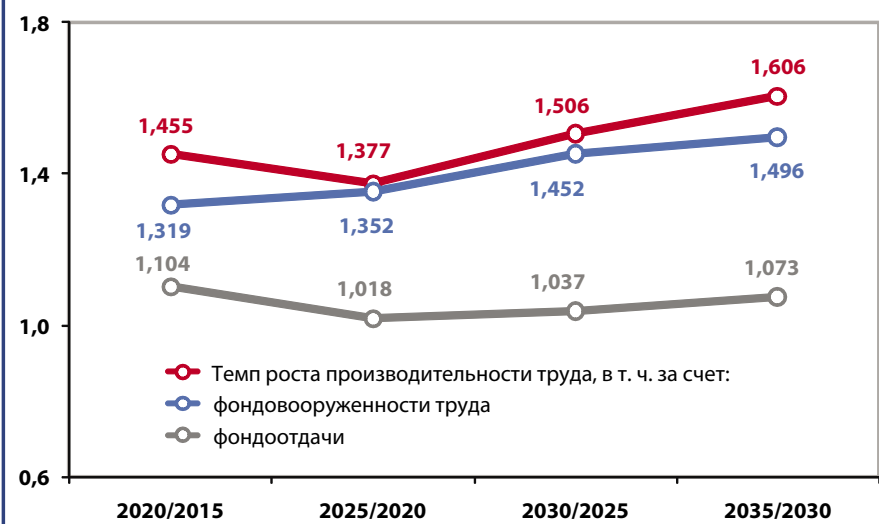

B

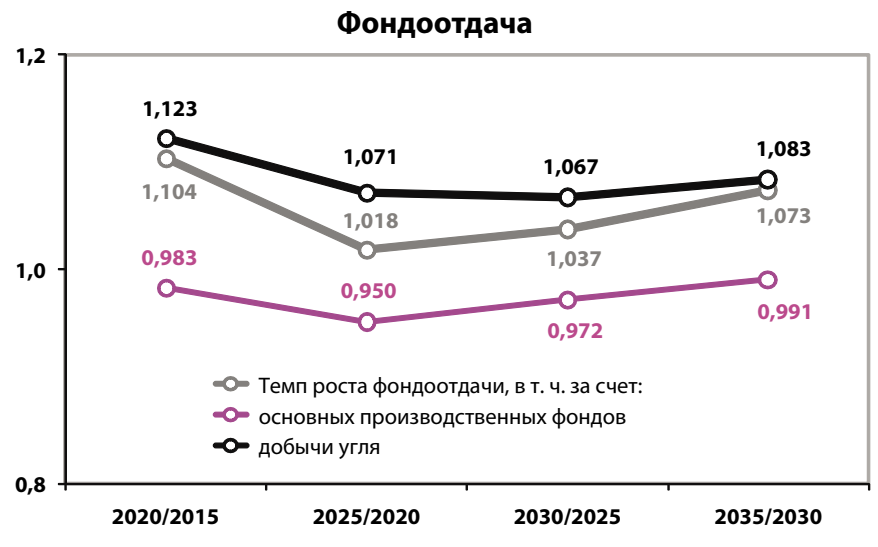

- долю инвестиций, направляемых на реконструкцию и модернизацию, в общем объеме инвестиций в основной капитал повысить до 62\% в 2035 г.;

- долю затрат на приобретение машин, оборудования и транспортных средств в общем объеме инвестиций в основной капитал увеличить до 90\% в 2035 г.

При этих условиях технологического развития отрасли рост фондовооруженности труда в 3,9 раза и рост фондоотдачи на 25, $1 \%$ позволят увеличить производительность труда в 2035 г. по сравнению с 2015 г. в пять раз при росте добычи угля на $39 \%$.

Зависимости темпов изменения основных показателей технологического развития угольной промышленности при реализации инновационного сценария в период до 2035 г. (в неизменных ценах) приведены на рис. 4.

\section{ЗАКЛЮЧЕНИЕ}

Таким образом, на основании ретроспективной и прогнозной оценки эффективности технологического развития угольной промышленности России можно сделать следующие основные выводы:

- сохранение действующих условий технологического развития отрасли приведет к постепенному снижению темпов роста производительности труда в связи с ограниченными возможностями расширения использования экстенсивных факторов;

- повысить производительность труда до уровня развитых угледобывающих стран возможно только при реализации показателей технологического развития отрасли по
6

Фондовооруженность труда

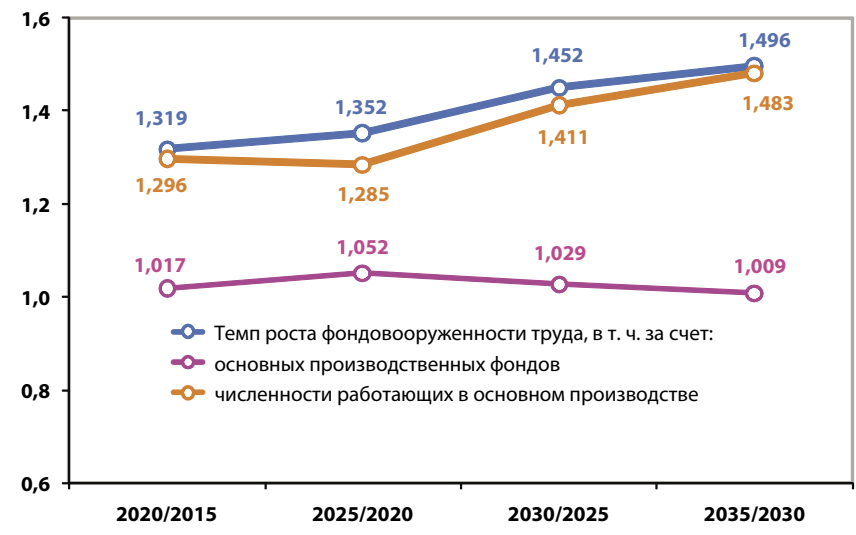

Источник: расчеты авторов

Puc. 4. Зависимости темпов изменения основных показателей технологического развития угольной промышленности при реализации инновационного сценария в период до 2035 г. (в неизменных ценах 2012 г.)

Fig. 4. Coal industry technological development indicators variability rate under innovative scenario implementation until 2035 (stable prices, 2012)

двум предлагаемым сценариям достижения необходимых стратегических ориентиров добычи угля и производительности труда на период до 2035 г. - умеренного технологического развития и инновационного технологического развития;

- для решения этой задачи необходимо:

- повысить уровень технологического обновления производственной базы отрасли в пределах 10-13\% годовых;

- увеличить темп роста фондоотдачи вводимых основных производственных фондов в 1,9-2,3 раза;

- поднять уровень фондовооруженности труда в 3,2-3,9 раза;

- увеличить долю затрат на приобретение машин, оборудования и транспортных средств в общем объеме инвестиций в основной капитал до 88-90\%;

- реализовать механизмы государственного нормативноправового и организационно-экономического регулирования, способствующие использованию нового высокопроизводительного оборудования в угольной промышленности, в том числе на основе локализации его производства при импортозамещении;

- только при выполнении этих условий может быть реализован целевой индикатор по росту производительности труда, намеченный в «Программе развития угольной промышленности России на период до 2030 года», позволяющий сократить технологическое отставание угольной отрасли от уровня развитых стран и выйти на инновационный устойчивый путь развития [4];

- при этом достижение целей инновационного развития российской угольной промышленности при перехо- 
де к новому технологическому укладу возможно только в случае качественных изменений бизнес-процессов, реализуемых на предприятиях:

- активного внедрения элементов промышленной стратегии «Индустрия-4.0», включая автоматизацию и роботизацию проведения горных выработок, выемки и переработки угля; технологии геоинформационного обеспечения и системы автоматического управления на горных предприятиях, учитывающих горнотехнические особенности российских месторождений и российские стандарты; цифровое 3D-моделирование геомеханических процессов при разработке месторождений; Интернет вещей при подземном и открытом способах добычи угля (комплексы «Умная шахта», «Интеллектуальный разрез»), при переработке («Саморегулируемая (умная) фабрика») и транспортировке угля («Умный транспорт»);

- повышения качества производимой угольной продукции за счет дифференциации шахтного и карьерного фондов с выделением групп предприятий по уровню технологического развития;

- организации производственных процессов и освоения новых инновационных технологий на перспективныхугледобывающихи перерабатывающихпредприятиях;

- повышения уровня научно-исследовательских и опытно-конструкторских работ;
- подготовки отраслевых кадров в соответствии с требованиями промышленной стратегии «Индустрия-4.0»;

- изменения подходов к управлению инновационным угольным предприятием, в частности, оценки текущего уровня и стратегии развития, планирования конкурентоспособности, развития процессов интеграции с различными субъектами инновационной экономической среды.

\section{Список литературы}

1. Система показателей Росстата для статистической оценки уровня технологического развития отраслей экономики. [Электронный ресурс]. URL: http://www.gks. ru/wps/wcm/connect/rosstat_main/rosstat/ru/statistics/ economydevelopment/ (дата обращения: 15.12.2017).

2. Захаров В.Н. Технологическая платформа твердых полезных ископаемых / Технополис XXI «Технологические платформы в России», № 31 (2014). С. 14-18.

3. Технологическая платформа «Экологически чистая тепловая энергетика высокой эффективности». [Электронный ресурc]. URL: http://science.spb.ru/files/tehplatformy/ tepen/presentation/\#1 (дата обращения: 15.12.2017).

4. Распоряжение Правительства Российской Федерации от 21 июня 2014 г. № 1099-р «О Программе развития угольной промышленности России на период до 2030 года». [Электронный ресурс]. URL: http://rosugol.ru/upload/pdf/ Programma_21_06_2014.pdf (дата обращения: 15.12.2017).

ECONOMIC OF MINING

UDC 658.155:622.33 (470) () M.P. Voskoboinik, A.A. Rozhkov, 2018

ISSN 0041-5790 (Print) • ISSN 2412-8333 (Online) • Ugol' - Russian Coal Journal, 2018, № 2, pp. 48-53

Title

RUSSIAN COAL INDUSTRY TECHNOLOGICAL DEVELOPMENT EFFICIENCY HISTORICAL AND PREDICTIVE ANALYSIS

DOI: http://dx.doi.org/10.18796/0041-5790-2018-2-48-53

Authors

Voskoboinik M.P. ${ }^{1}$, Rozhkov A.A. ${ }^{2,3}$

${ }^{1}$ Moscow, 117186, Russian Federation

${ }^{2}$ National University of Science and Technology "MISIS" (NUST "MISIS"), Moscow, 119049, Russian Federation

3 "Rosinformugol", JSC, Moscow, 119049, Russian Federation

\section{Authors' Information}

Voskoboinik M.P., Doctor of Economic Sciences, tel.: +7 (495) 610-83-20, e-mail: mivoskob@mail.ru

Rozhkov A.A., Doctor of Economic Sciences, Professor, Chairman Board of Directors, tel.: +7 (499) 236-81-55, e-mail: aarozhkov@mail.ru

\section{Abstract}

Russian coal industry technological development 2012-2016 historical analysis is provided and predictive calculations until 2035 are offered with account for major industry technological parameters variability. Coal industry technological development predictive factor analysis applies calculations based on production-financial mathematical model, covering three different scenarios: inertia, moderate and innovative technical development. Coal industry labor efficiency growth long-term conditions are established based on intensive factors.

Figures:

Fig. 1. Single employee average monthly labor efficiency growth rate as a function of capital-labor ratio growth and capital productivity decrease in 2012-2016 (stable prices)

Fig. 2. Coal industry technological development indicators variability rate under inertia scenario implementation until 2035 (stable prices)

Fig. 3. Coal industry technological development indicators variability rate under moderate development scenario implementation until 2035 (stable prices)

Fig. 4. Coal industry technological development indicators variability rate under innovative scenario implementation until 2035 (stable prices)

\section{Keywords}

Technological development, Labor efficiency, Labor capital productivity and capital-labor ratio, Growth rate, Capital investments, Extensive and intensive factors, Scenarios: inertia, moderate and innovative technological development.

\section{References}

1. Sistema pokazateley Rosstata dlya statisticheskoy otsenki urovnya tekhnologicheskogo razvitiya otrasley ekonomiki [Federal Statistics Service indicators for economic activities technological development level statistic evaluation].Web-resource. Available at: http://www.gks.ru/wps/wcm/connect/rosstat_main/rosstat/ru/statistics/economydevelopment/(accessed 15.12.2017). 2. Zakharov V.N. Tekhnologicheskaya platforma tverdyh poleznyh iskopaemyh. Tekhnopolis XXI [Solid mineral resources technological platform. Tekhnopolis XXI]. Tekhnologicheskie platformy $v$ Rossii - Technological platforms in Russia, 2014, No. 31, pp. 14-18.

3. Tekhnologicheskaya platforma "Ekologicheski chistaya teplovaya energetika vysokoy effektivnosti" [Technological platform "High efficient environmentally safe thermal energy". Web-resource. Available at: http://science.spb.ru/files/ tehplatformy/tepen/presentation/\#1 (accessed 15.12.2017).

4. Rasporyazhenie Pravitelstva Rossiyskoy Federatsii ot 21 iyunya $2014 \mathrm{~g}$ №1099-r "O Programmerazvitiya ugolnoy promyshlennosti Rossiina period do 2030 goda" [Resolution of the Government of the Russian Federation No. 1099-p dated 21 June 2014 "On Russian coal industry development until 2030"]. Web-resource. Available at: http://rosugol.ru/upload/pdf/Programma_21_06_2014.pdf(accessed 15.12.2017). 


\section{Соглашение о государственно-частном партнерстве как форма реализации проекта переработки углей В синтетическое жидкое топливо на территории} Приморского края

DOI: http://dx.doi.org/10.18796/0041-5790-2018-2-54-60

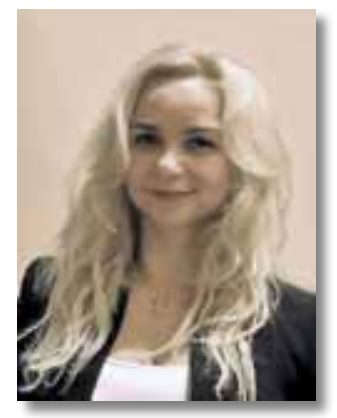

\author{
БАКУРОВА \\ Елена Владимировна \\ Соискатель Школы \\ экономики и менеджмента \\ Дальневосточного \\ федерального университета, \\ 690090 , г. Владивосток, Россия, \\ тел.: +7 (914) 791-70-71, \\ e-mail:bakurovs@yandex.ru
}

Современная угольная промышленность - это не только угледобыча, это инновационные перерабатывающие производства и прорывные технологии. Особое внимание необходимо уделить развитию производства глубокой переработки угля, увеличению экспорта продуктов С высокой добавленной стоимостью. Важная роль отводится государственно-частному партнерству как одной из форм взаимодействия государственных органов и частного бизнеса при реализации крупномасштабных социально значимых проектов. В работе показана возможность реализации инновационного подхода к развитию угольной отрасли Приморского края с использованием механизма государственно-частного партнерства.

Ключевые слова: государственно-частное партнерство (ГЧП), уголь, инновационное развитие предприятий угольной отрасли, углепереработка, синтетическое жидкое топливо (СЖТ), проект переработки углей в СЖТ, Приморский край, структурирование проектов ГЧП.

\section{ВВЕДЕНИЕ}

В свете современной инновационной политики использование механизмов государственно-частного партнерства (ГЧП) является актуальной задачей как для топливно-энергетического комплекса страны в целом, так и отраслей, входящих в него, а именно угольной промышленности. Дальнейшее развитие угольной отрасли исследователи связывают с ее инновационным развитием на основе внедрения прорывных технологий глубокой переработки угольного сырья, выпуска продукции с новыми потребительскими свойствами. Важная роль отводится государственно-частному партнерству как ключевому механизму, позволяющему реализовать крупномасштабные комплексные социально значимые проекты с учетом интересов государственных органов и частного бизнеса.

Например, в работе Л.С. Плакиткиной [1] показано, что в угольную промышленность России необходимо вкладывать преимущественно те инвестиции, которые могут привести к повышению производительности труда не менее чем в 3-5 раз. Такими инвестициями являются вложения в высокоинновационные технологии в области геологоразведки, добычи и переработки угля.

Т.В. Кретинина рассматривает факторы экономического роста в постдепрессивном угольном регионе (на примере Восточного Донбасса) [2]. Среди инновационных факторов автор выделяет использование механизмов государственно-частного партнерства и создание механизмов поддержки градообразующих предприятий. Ведущая роль отводится инновационному подходу к использованию природных ресурсов (угля), отмечается экономическая эффективность глубокой переработки угля на основе отечественной и зарубежной практики. Такой подход позволит сменить вектор развития региона от сырьевого, монопрофильного к перерабатывающему.

С.М. Никитенко, Е.В. Гоосен [3] отмечают, что в условиях экономических санкций возможность дальнейшего развития страны за счет добычи и реализации на внешнем рынке природных ресурсов не имеет перспектив. В ближайшие годы России предстоит создать новую модель развития, опирающуюся на внутренние источники развития: комплексное освоение недр, устойчивое развитие территорий, партнерство власти и бизнеса. Ключевую роль в этом предстоит сыграть проектному подходу, реализуемому на принципах государственно-частного партнерства в рамках сотрудничества государства, бизнеса и научно-образовательных учреждений.

\section{ГОСУДАРСТВЕННО-ЧАСТНОЕ ПАРТНЕРСТВО}

За рубежом традиционно государственно-частное партнерство осуществляется в сфере ответственности государства и направлено на развитие инфраструктуры. Однако, как показывает опыт и анализ российской специфики, сфера реализации ГЧП может быть гораздо шире: от реализации инфраструктурных проектов общегосударственного значения до разработки и адаптации особо перспективных технологий для новых точек роста там, где сосредоточены значительный научный потенциал и человеческий капитал. 
На наш взгляд, одно не противоречит другому. Зачастую крупномасштабные общественно-значимые проекты носят комплексный характер, и инвестиционные затраты на их осуществление включают в себя не только ту часть, которая приносит экономические выгоды в виде прибыли, но для реализации и запуска проекта требуется создание инфраструктуры (дорог, источников электроснабжения, объектов социальной сферы и пр.). Все это, безусловно, влияет на первоначальные инвестиции по проекту, и без государственной поддержки реализация проекта может оказаться экономически нецелесообразной. Государственно-частное партнерство, выраженное в объединении ресурсов, в данном случае позволяет оптимизировать эффективность проекта, удовлетворить интересы частных инвесторов в получении дохода, решить общегосударственные задачи развития региона и страны в целом.

Сферы применения ГЧП очень разнообразны - это прежде всего инфраструктура, ЖКХ, дороги, образование, медицина и другие секторы. Приоритетная отрасль, которая выбирается для привлечения в нее инвестиций с помощью ГЧП, зависит от социально-экономического уровня развития страны и реализуемой политики государства. В современныхусловиях особую актуальность приобретают вопросы, связанные с применением ГЧП в инновационной области, когда из-за высокого риска недостижимости требуемых результатов на различных стадиях создания и рыночного освоения инноваций особенно желательна поддержка государственных структур. Исключительная значимость государственно-частного партнерства как эффективного инструмента реализации инновационной политики признается ведущими зарубежными странами. ПрограммыГЧП, стимулирующие тесные контакты между научным и промышленным секторами экономики и ориентирующие государственные исследования на промышленные инновации, характерны для всех промышленно развитых государств.

В рамках ГЧП государство не только берет часть риска и инвестирует в значительной мере в новые проекты. Главной его задачей является создание общеэкономических условий, определяющих развитие инновационнойдеятельности.

С 1 января 2016 г. вступил в силу Федеральный закон от 13 июля 2015 г. № 224-Ф3 «О государственно-частном партнерстве, муниципально-частном партнерстве в Российской Федерации и о внесении изменений в отдельные законодательные акты Российской Федерации». В законе о ГЧП дается следующее определение государственночастного партнерства: юридически оформленное на определенный срок и основанное на объединении ресурсов, распределении рисков сотрудничество публичного партнера, с одной стороны, и частного партнера, с другой стороны, которое осуществляется на основании соглашения о ГЧП, заключенного в соответствии с настоящим федеральным законом в целях привлечения в экономику частных инвестиций, обеспечения органами государственной власти и органами местного самоуправления доступности товаров, работ, услуг и повышения их качества.

В целях обеспечения практической реализации закона о ГЧП введено достаточно четкое регламентирование процессов инициирования, разработки, оценки, принятия решения о реализации, определения частного партнера для реализации проекта государственно-частного партнерства.
Определен перечень объектов соглашения о государственно-частном партнерстве, который охватывает практически все отрасли. К объектам в сфере топливноэнергетического комплекса, и в частности угольной промышленности, в отношении которых возможно заключение соглашений оГЧП (224-Ф3), относятся: имущественные комплексы, предназначенные для производства промышленной продукции и (или) осуществления иной деятельности в сфере промышленности (п. 18 введен Федеральным законом от 03.07.2016 № 360-Ф3); объекты по производству, передаче и распределению электрической энергии.

Сторонами соглашения о ГЧП, МЧП являются публичный и частный партнеры. Частный партнер - российское юридическое лицо, с которым заключено соглашение о ГЧП. Публичный партнер - Российская Федерация, субъект Российской Федерации или муниципальное образование. Федеральным законом предусматривается обязательное определение уполномоченного органа субъекта Российской Федерации (муниципального образования).

Разработку предложения о реализации проекта ГЧП, МчП может обеспечить как публичный, так и частный партнер. Механизм частной инициативы, предусмотренный в законе о ГЧП, имеет следующие преимущества:

- сокращается процедура отбора частного партнера в случае, если нет других интересантов;

- у частного партнера есть легитимный способ предложить публичному партнеру проект ГЧП на своих условиях.

Эффективность проекта ГЧП и его сравнительное преимущество - обязательное условие для принятия решения о реализации соответствующего проекта. Оценка эффективности проекта ГЧП проводится уполномоченным органом на основании следующих критериев:

- финансовая эффективность;

- социально-экономический эффект от реализации проекта ГЧП, рассчитанный с учетом целей и задач, определенных в документах стратегического планирования.

Если по итогам оценки проект признан эффективным по каждому из указанных критериев, определяется его сравнительное преимущество. Утверждение уполномоченным органом положительного заключения по проекту является обязательным условием для реализации проекта ГЧП.

Согласно «Долгосрочной программе развития угольной промышленности России до 2030 года» (утверждена распоряжением Правительства РФ от 21 июня 2014 г. № 1099-р) предусматривается создание угольно-технологических (включая глубокую переработкуугля), углехимических (в том числе получение СЖТ из низкокачественных коксующихся углей) и энергоугольных кластеров, позволяющих комплексно использовать возможности угольных месторождений.

Одним из путей развития угольной отрасли Приморского края на основе инновационного подхода, по нашему мнению, может быть строительство завода по производству СЖТ из приморских бурых углей мощностью 500 тыс. т жидких продуктов в год [4]. Для создания такого производства требуются инвестиции в объеме, эквивалентном 254 млн дол. США., включая долевое участие в строительстве электростанции [5]. По нынешнему курсу такие затраты составляют до 16,510 млрд руб. Общая сумма капитальных вложений по комплексному проекту, с учетом энергоисточника (типовая ТЭС), оценивается в 500 млн дол. США, или 32,5 млрд руб. [6]. Поскольку при таком объеме сум- 
Финансово-экономические показатели эффективности проекта организации производства синтетического жидкого топлива (СЖТ) из угля на заводе мощностью 500 тыс. т жидких продуктов в год на территории Приморского края без применения и с применением государственно-частного партнерства

\begin{tabular}{|c|c|c|c|c|c|}
\hline \multirow{2}{*}{ Показатели } & \multirow{2}{*}{$\begin{array}{c}\text { Реализация } \\
\text { проекта только } \\
\text { за счет средств } \\
\text { частного } \\
\text { инвестора без } \\
\text { механизма ГЧП }\end{array}$} & \multicolumn{3}{|c|}{$\begin{array}{c}\text { Реализация проекта на основе механизма ГЧП } \\
\text { на территории Приморского края } \\
\text { без предоставлении налоговых льгот ТОСЭР }\end{array}$} & \multirow{2}{*}{$\begin{array}{l}\text { Реализация проекта } \\
\text { на основе механизма } \\
\text { ГЧП на территории } \\
\text { Приморского края } \\
\text { с предоставлением } \\
\text { налоговых льгот ТОСэР }\end{array}$} \\
\hline & & $\begin{array}{c}\text { Производ- } \\
\text { ственная } \\
\text { часть }\end{array}$ & $\begin{array}{l}\text { Инфраструк- } \\
\text { турная часть }\end{array}$ & $\begin{array}{l}\text { Проект } \\
\text { в целом }\end{array}$ & \\
\hline Источник финансирования & $\begin{array}{c}\text { Средства } \\
\text { частных } \\
\text { инвесторов }\end{array}$ & $\begin{array}{l}\text { Частный } \\
\text { партнер }\end{array}$ & $\begin{array}{c}\text { Публичный } \\
\text { партнер }\end{array}$ & $\begin{array}{c}\text { Смешанное } \\
\text { финансирование } \\
\text { на основе ГЧП }\end{array}$ & $\begin{array}{c}\text { Смешанное } \\
\text { финансирование } \\
\text { на основе ГЧП }\end{array}$ \\
\hline Капитальные вложения, млн руб. & 32500 & 16510 & 15990 & 32500 & 32500 \\
\hline $\begin{array}{l}\text { Чистая прибыль, плюс } \\
\text { амортизационные отчисления } \\
\text { в год, млн руб. }\end{array}$ & 5802 & 6278 & - & 6278 & $\begin{array}{l}7418 \text { (1-5 лет); } \\
7067 \text { (6-10 лет) }\end{array}$ \\
\hline $\begin{array}{l}\text { Суммарный бюджетный эффект } \\
\text { за счет экономии затрат } \\
\text { на топливо и дополнительных } \\
\text { налоговых поступлений в год, } \\
\text { млн руб. }\end{array}$ & 7823 & & 7770 & 7770 & $\begin{array}{l}6272 \text { (1-5 лет); } \\
6618 \text { (6-10 лет) }\end{array}$ \\
\hline NPV, млн руб. & -11138 & 6606 & 12619 & 19226 & 17905 \\
\hline PI & 0,66 & 1,40 & 1,79 & 1,59 & 1,55 \\
\hline Срок окупаемости, лет & Не окупается & 5 лет & 4 года & 4 года & 4 года \\
\hline
\end{tabular}

марных инвестиций в финансирование проекта только за счет средств инвесторов финансово-экономические показатели проекта в десятилетнем периоде прогнозирования имеют отрицательные значения (проект не окупается), то финансирование предлагается осуществлять за счет как частных инвесторов (производственная часть), так и регионального бюджета (инфраструктурная часть) (табл. 1).

Таким образом, участие государства в финансировании проекта значительно улучшает его экономические показатели, при этом каждый из партнеров извлекает значительную выгоду, и решаются социальные проблемы развития угольной отрасли края.

Исследование моделей и механизмов ГЧП имеет важное значение для поиска источников финансирования и выбора структуры реализации проекта переработки углей в СЖТ. Под структурированием проекта понимается процесс достижения между всеми будущими участниками проекта компромисса в отношении его основных параметров (срок, сумма, доли участия и риски каждой из сторон), в результате чего становится возможной практическая реализация данного проекта [7].

Наиболее приемлемой формой ГЧП при реализации крупномасштабных проектов переработки углей в СЖТ, на наш взгляд, является соглашение о государственночастном партнерстве в рамках Закона № 224-Ф3, когда частная сторона осуществляет строительство объекта, получает право собственности на объект, осуществляет эксплуатацию объекта и получает доход от эксплуатации. Механизм реализации проекта переработки углей в СЖТ на заводе мощностью 500 тыс. т жидких продуктов в год на территории Приморского края в рамках государственночастного партнерства представлен на рис. 1.

Преимуществом данной модели в рамках соглашения о ГЧП является возможность привлечения софинансирования проекта из бюджетных источников, возникновения частной собственности на создаваемый инфраструктурный объект (типовая ТЭС) у частного партнера, а также возможность учета государственного интереса и потребности бизнеса в государственной поддержке. При этом законодательно гарантируется неизменность правил игры на весь период действия соглашения и предусмотрена возможность пересмотра условий соглашения в случае изменения макроэкономических условий и законодательства, напрямую затрагивающих проект (налоги, льготы и т.д.).

Сложный объектный состав проектов переработки углей в синтетическое жидкое топливо позволяет отнести их к комплексным инвестиционным проектам в сфере угольной промышленности. Это обусловливает специфику их оценки и структурирования в рамках ГЧП. Ниже описан авторский подход к оценке и определению оптимальной доли государственного участия в реализации проектов переработки углей в СЖТ.

\section{ПОДХОД К ОЦЕНКЕ И ОПРЕДЕЛЕНИЮ \\ ОПТИМАЛЬНОЙ ДОЛИ ГОСУДАРСТВЕННОГО \\ УЧАСТИЯ В РЕАЛИЗАЦИИ ПРОЕКТОВ ПЕРЕРАБОТКИ УГЛЕЙ В СЖТ}

Важную роль в отборе проектов инвестором играет характеристика эффективности проекта, основанная на построении чистого дисконтированного дохода (NPV), полученного в результате реализации проекта:

$$
N P V=\sum_{k=1}^{n} \frac{P_{k}}{(1+r)^{k}}-I C_{\text {общ, }}
$$

где: $I C_{\text {общ }}$ - первоначальный суммарный объем инвестиций; $P_{k}$ - годовой доход (чистая прибыль и амортизационные отчисления); $r$ - ставка дисконтирования; $n$ - количество лет реализации проекта.

Показатель $N P V$ отражает общий уровень эффективности проекта и соответствует дисконтированному потоку 


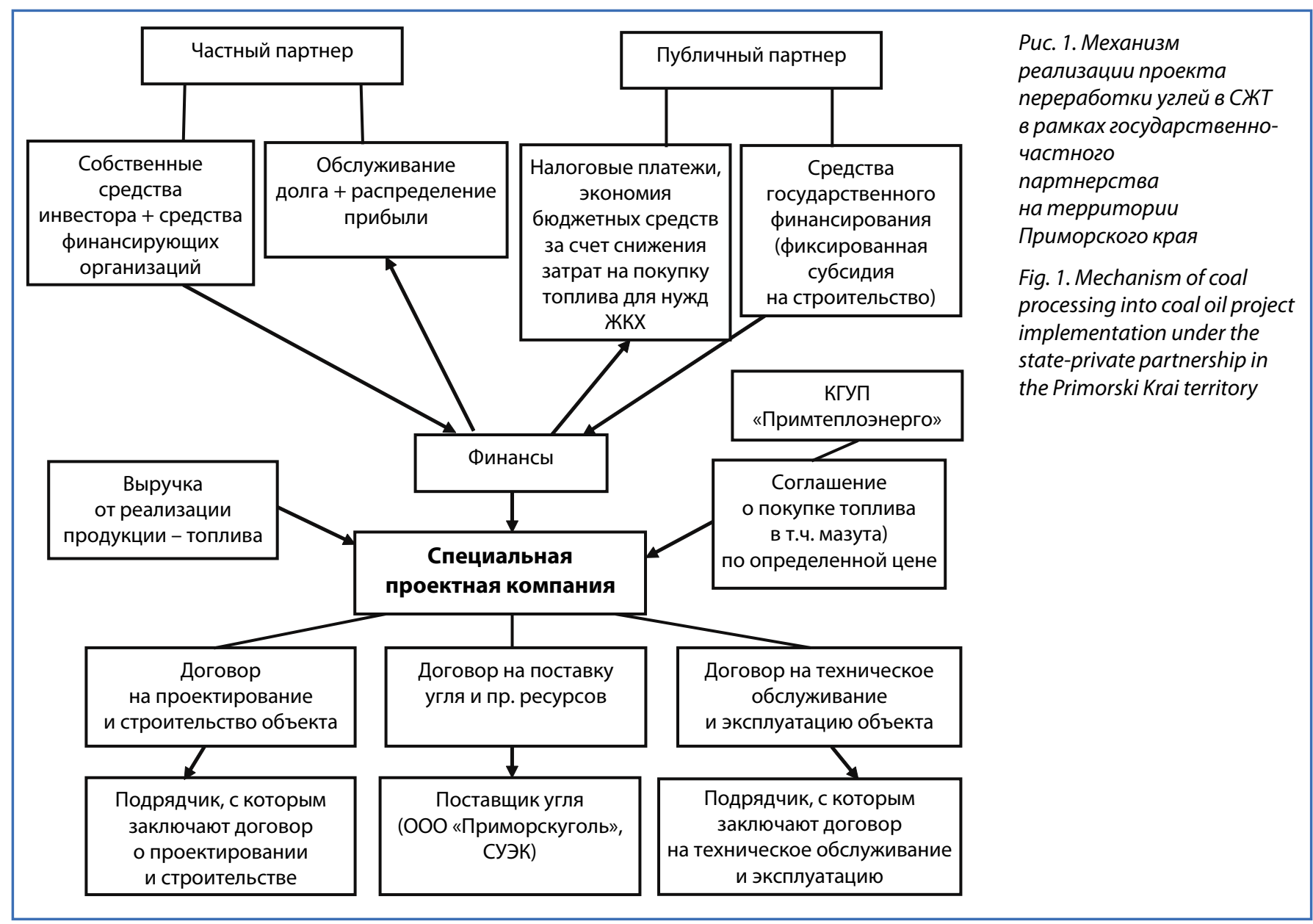

наличности пары «частный инвестор - государство», где государство играет пассивную роль собственника ресурсов и получателя налоговых доходов в соответствии с фиксированной системой налогообложения.

Активная позиция государства, использующего механизмы ГЧП, существенно меняет дело. В рамках ГЧП государство уже участвует в финансировании капитальных вложений, строя часть инфраструктурных объектов, необходимых для реализации технологического проекта, и осуществляя некоторый набор проектных природоохранных мероприятий. В этой ситуации для государства может быть построено аналогичное (1) $N P V_{\text {гос }}$ в котором используются больший временной горизонт $n g$ и меньший, чем у инвестора, дисконт $r_{\text {гос }}$ :

$$
N P V_{\text {гос }}=\sum_{k=1}^{n g} \frac{\operatorname{tax}^{t}+P_{\text {гос }}}{\left(1+r_{\text {гос }}\right)^{k}}-I C_{\text {гос }} \text {. }
$$

Здесь расходы государства $I C_{\text {гос }}$ - капитальные вложения в инфраструктуру и природоохранные мероприятия, а в составе доходов присутствуют не только налоговые платежи $\operatorname{tax}^{t}$ от оцениваемого проекта, но и внепроектные и прочие дополнительные доходы $P_{\text {гос }}$, порождаемые со временем развитием инфраструктуры территории.

Для частного инвестора ключевым показателем эффективности является аналог (1) - $N P V_{\text {ин, }}$ в котором капитальные расходы уменьшены с учетом партнерского участия государства, а в качестве дополнительных расходов включены налоговые платежи:

$$
N P V_{\text {инв }}=\sum_{k=1}^{n} \frac{P_{k}}{\left(1+r_{\text {инв }}\right)^{k}}-\left(I C_{\text {общ }}-I C_{\text {гос }}\right) .
$$

Инвестору интересен проект, если $N P V_{\text {инв }}>0$.

На наш взгляд, возможность возникновения конфликта можно исключить путем уравновешивания экономических интересов основных участников проекта - государства и бизнеса. Если исходить из гипотезы существования равновесной эффективности, должно соблюдаться условие равенства эффективности для инвестора и государства:

$$
\begin{aligned}
& N P V_{\text {гос }}=N P V_{\text {инв }} \\
& \sum_{k=1}^{n g} \frac{\operatorname{tax}^{t}+P_{\text {гос }}}{\left(1+r_{\text {гос }}\right)^{k}}-I C_{\text {гос }}=\sum_{k=1}^{n} \frac{P_{k}}{\left(1+r_{\text {инв }}\right)^{k}}-I C_{\text {общ }}+I C_{\text {гос }}
\end{aligned}
$$

Введем обозначения:

$P V_{\text {гос }}=\sum_{k=1}^{n g} \frac{\operatorname{tax}^{t}+P_{\text {гос }}}{\left(1+r_{\text {гос }}\right)^{k}}-$ общая накопленная величина дисконтированных доходов государства;

$P V_{\text {инв }}=\sum_{k=1}^{n} \frac{P_{k}}{\left(1+r_{\text {инв }}\right)^{k}}$ - общая накопленная величина дисконтированных доходов инвестора.

Преобразование формул дает следующие равенства:

- оптимальная сумма капитальных затрат по проекту, принимаемых на себя государством:

$$
I C_{\text {гос }}^{\text {опт }}=\frac{P V_{\text {гос }}-P V_{\text {инв }}+I C_{\text {общ }}}{2} ;
$$

- оптимальная доля участия государства в финансировании проекта ГЧП:

$$
W_{\text {гос }}^{\text {опт }}=\frac{I C_{\text {гос }}^{\text {опт }}}{I C_{\text {общ }}}
$$




$$
W_{\text {гос }}^{\text {опт }}=\frac{P V_{\text {гос }}-P V_{\text {инв }}+I C_{\text {общ }}}{2 I C_{\text {общ }}} .
$$

Оптимальная доля финансирования, согласно данному равенству, характеризует область согласованных интересов публичного и частного партнеров. Графически это отображается точкой пересечения кривых $N P V_{\text {инв }}$ и $N P V_{\text {гос. }}$.

Подход протестирован на проекте переработки углей в СЖТ на территории Приморского края с применением механизма ГЧП сучетом производственной и инфраструктурной частей проекта.

На территории Приморья реализация проекта имеет значительный бюджетный эффект, в том числе за счет экономии затрат на покупку дальнепривозного топлива (мазута) для нужд ЖКХ [8]. От реализации проекта государственный (публичный) партнер выигрывает в большей мере. Поэтому имеется значительный резерв в вопросах структурирования инвестиционных затрат на этапе ведения переговоров и привлечения частного партнера для участия в финансировании проекта. Кроме того, для привлечения частного партнера в Приморском крае целесообразно использовать налоговые льготы, предусмотренные для резидентов территорий опережающего социально-экономического развития (ТОСЭР), а именно налог на прибыль по ставке 5\% в течение первых пяти лет и 10\% в последующие пять лет; налог на имущество организаций по ставке $0 \%$; страховые взносы в государственные внебюджетные фонды по ставке 7,6\%.

Для каждого варианта реализации проекта были выполнены расчеты, на основе которых проведена оценка эффективности проекта (табл. 2).

Далее выполнен расчет оптимальной суммы капитальных затрат по проекту, принимаемых на себя государством, и оптимальной доли участия государства в финансировании проекта ГЧП по предложенным выше формулам (5), (6). Ставка дисконтирования принята на уровне $24 \%$ для государственного и частного партнеров, показатели рассчитаны сроком на 10 лет (табл. 3, 4).

В варианте реализации проекта переработки углей в СЖТ на заводе мощностью 500 тыс. т на территории Приморского края без предоставления налоговых льгот отмечается превышение оптимальной доли участия государства в финансировании проекта ГЧП (58,5\%) над долей государства в финансировании проекта в базовом варианте $(49,2 \%)$. Поскольку в данном случае равенство бюджетной и финансовой эффективности не достигается, то оптимальная доля государства ограничивается долей участия государства в базовом варианте финансирования инфраструктурной части проекта - 49,2\%, баланс интересов государственных и частных структур не достигнут. Требуют-

Таблича 2

\section{Исходные данные по проекту переработки углей в СЖТ из угля на заводе мощностью 500 тыс. т на территории Приморского края}

\begin{tabular}{|c|c|c|}
\hline \multirow[b]{2}{*}{ Исходные финансовые параметры } & \multicolumn{2}{|c|}{ Вариант реализации проекта } \\
\hline & $\begin{array}{c}\text { Без предоставления } \\
\text { льгот }\end{array}$ & $\begin{array}{c}\text { С предоставлением } \\
\text { льгот }\end{array}$ \\
\hline Суммарные инвестиции, млн руб. (IC общ) & 32500 & 32500 \\
\hline Объем инвестиций по объекту производства, млн руб. & 16510 & 16510 \\
\hline $\begin{array}{l}\text { Инвестиции в инфраструктурные объекты и природоохранные мероприятия, } \\
\text { млн руб. }\end{array}$ & 15990 & 15990 \\
\hline Доля государства в базовом варианте, \% & 49,2 & 49,2 \\
\hline Ежегодная прибыль до налогообложения, млн руб. & 6919 & 7063 \\
\hline Ставка налога на прибыль, \% & 0,2 & $\begin{array}{l}0,05 \text { (1-5 лет); } \\
0,1 \text { (6-10 лет) }\end{array}$ \\
\hline Чистая прибыль, млн руб. & 5536 & $\begin{array}{l}6675 \text { (1-5 лет); } \\
6324 \text { (6-10 лет) }\end{array}$ \\
\hline Амортизационные отчисления, млн руб. & 743 & 743 \\
\hline Ежегодные налоговые поступления, млн руб. $\left(\operatorname{tax}^{t}\right)$ & 4570 & $\begin{array}{l}3072 \text { (1-5 лет); } \\
3418 \text { (6-10 лет) }\end{array}$ \\
\hline Внепроектные и прочие дополнительные доходы государства, млн руб. ( $\left.P_{\text {гос }}\right)$ & 3200 & 3200 \\
\hline
\end{tabular}

Таблича 3

\section{Доходы по проекту переработки углей в СЖТ на заводе мощностью 500 тыс. т на территории Приморского края на период 10 лет}

Доходы от реализации проекта
Общая накопленная величина дисконтированных доходов ( $\left.P V_{\text {гос }}, P V_{\text {инв }}\right)$ по ставке дисконтирования $24 \%$, млн руб.

\section{Без предоставления налоговых льгот}

Чистые потоки государства (налоговые поступления + внепроектные 77707770 и прочие дополнительные доходы государства), млн руб.

Чистые потоки инвестора (чистая прибыль + амортизация), млн руб. 62786278

28609

\section{С предоставлением налоговых льгот}

Чистые потоки государства (налоговые поступления + внепроектные 62726618 и прочие дополнительные доходы государства), млн руб.

Чистые потоки инвестора (чистая прибыль + амортизация), млн руб. 74187067

23116

23415

26984 


\begin{abstract}
Оптимальная сумма капитальных затрат по проекту переработки углей в СЖТ на заводе мощностью 500 тыс. т на территории Приморского края, принимаемая на себя государством, и оптимальная доля участия государства в финансировании проекта ГЧП
\end{abstract}

\begin{tabular}{|c|c|c|}
\hline \multirow[t]{2}{*}{ Финансовые параметры } & \multicolumn{2}{|c|}{$\begin{array}{c}\text { Вариант реализации проекта переработки углей в } \\
\text { СЖТ на заводе мощностью } 500 \text { тыс. т } \\
\text { на территории Приморского края } \\
\end{array}$} \\
\hline & $\begin{array}{c}\text { Без предоставления } \\
\text { налоговых льгот }\end{array}$ & $\begin{array}{c}\text { С предоставлением } \\
\text { налоговых льгот ТОСЭР }\end{array}$ \\
\hline $\begin{array}{l}\text { Общая накопленная величина дисконтированных } \\
\text { доходов государства }\left(P V_{\text {гос }}\right) \text {, млн руб. }\end{array}$ & 28609 & 23415 \\
\hline $\begin{array}{l}\text { Общая накопленная величина дисконтированных } \\
\text { доходов инвестора }\left(P V_{\text {инб }}\right) \text {, млн руб. }\end{array}$ & 23116 & 26984 \\
\hline Суммарные инвестиции, млн руб. (IC обш $)$ млн руб. & 32500 & 32500 \\
\hline $\begin{array}{l}\text { Оптимальная сумма капитальных затрат по проекту, } \\
\text { принимаемых на себя государством (I гот }) \text {, млн руб. }\end{array}$ & 18996 & 14466 \\
\hline $\begin{array}{l}\text { Оптимальная доля участия государства в финансировании } \\
\left.\text { проекта ГЧП ( } W_{\text {гос }}^{\text {опт }}\right)\end{array}$ & 0,585 & 0,445 \\
\hline
\end{tabular}

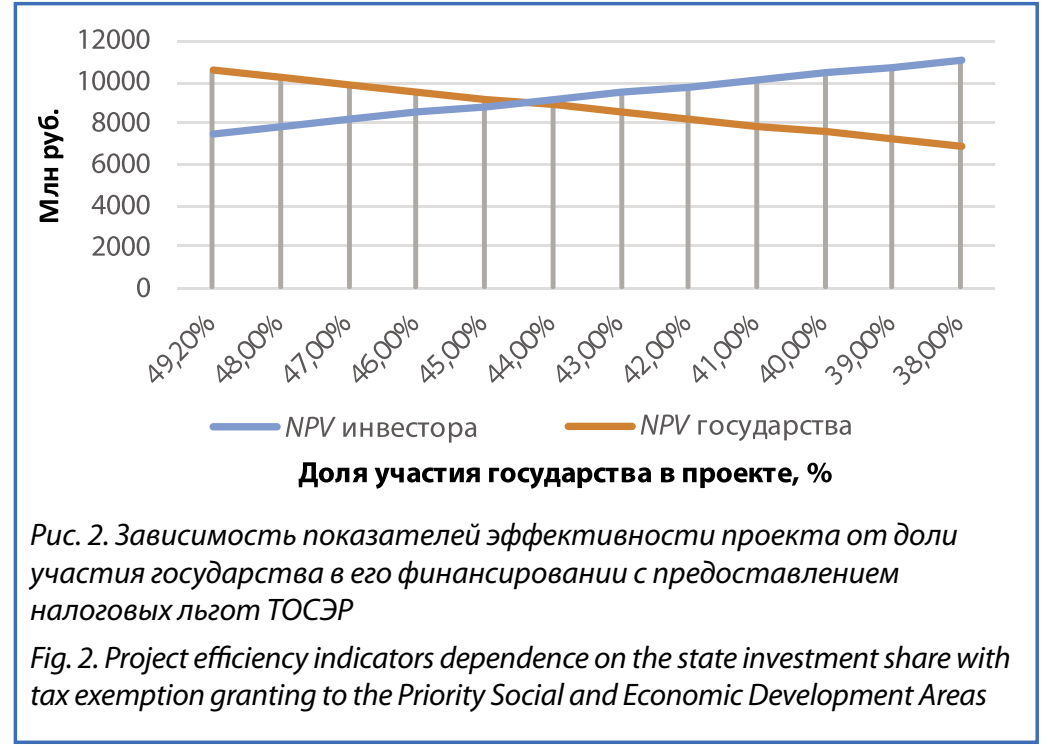

углей в синтетическое жидкое топливо позволяют осуществить комплексную оценку целесообразности реализации проекта, найти оптимальную конфигурацию объемов финансирования и мер поддержки в рамках проекта, что позволяет принимать экономически обоснованные управленческие решения относительно отбора таких проектов для реализации.

\title{
Список литературы
}

1. Плакиткина Л.С. Интенсификация инновационного процесса в угольной промышленности России // Горная Промышленность. 2011. № 3. С. 4-11.

2. Кретинина Т.В. Факторы экономического роста в постдепрессивном угледобывающем регионе: возможности и эффективность государственно-частногопартнерства//Инженерный вестник Дона. 2011. Т.17. Вып. № 3. С. 285-293.

ся дополнительные меры финансового стимулирования частного инвестора в реализации проекта. Такой мерой является применение налоговых льгот.

Применение налоговых льгот, предусмотренных для резидентов территорий опережающего социальноэкономического развития (ТОСЭР), позволяет достигать более сбалансированной структуры участия в проекте для частного и публичного партнеров. Полученное при этом равенство бюджетной и финансовой эффективности проекта позволяет государству передать некоторую часть расходов по инфраструктурному объекту частному партнеру и снизить долю финансового участия в проекте с 49,2 до 44,5\% (рис. 2).

На наш взгляд, такая схема ГЧП оптимальна для реализации проекта переработки углей в СЖТ на заводе мощностью 500 тыс. т на территории Приморского края и позволяет привлечь частного партнера с учетом сбалансированности интересов его участников.

\section{ЗАКЛЮЧЕНИЕ}

Предложенный алгоритм и методический инструментарий оценки и структурирования проектов переработки
3. Никитенко С.М., Гоосен Е.В. Комплексное освоение природных ресурсов на принципах государст-венно-частного партнерства // Горный информационно-аналитический бюллетень. 2015. № 1-2. С. 150-159.

4. Бакурова Е.В. Переработка углей в синтетическое жидкое топливо как стратегическое направление развития предприятий угольной отрасли Приморского края // Уголь. 2016, № 10, С. 46-50. URL: http://www.ugolinfo.ru/ Free/102016.pdf (дата обращения: 15.01.2018).

5. Шумейко М.В. Гидрогенизация угля // Горный информационно-аналитический бюллетень. 2008. № 9. С. 32-39.

6. Проект производства 500 тыс. т моторного топлива из угля [Электронный ресурс]:URL: http://www.uglerodtophim. ru/2010-10-08-13-37-44/24 (дата обращения 15.01.2018).

7. Мерзлов И.Ю. Подходы к структурированию проектов государственно-частного партнерства // Вопросы регулирования экономики. 2014. Т.5. № 1. С. 77-87.

8. Бакурова Е.В. Социально-экономические аспекты реализации проекта переработки углей в синтетическое жидкое топливо на территории Приморского края // Известия Дальневосточного федерального университета. 2016. № 1. С. 100-115. 
UDC 334.021:622.33(571.63) ๑ E.V. Bakurova, 2018

ISSN 0041-5790 (Print) • ISSN 2412-8333 (Online) • Ugol' - Russian Coal Journal, 2018, № 2, pp. 54-60

Title

AGREEMENT ON PUBLIC-PRIVATE PARTNERSHIP AS A FORM OF REALIZATION OF THE PROJECT

OF PROCESSING COAL INTO SYNTHETIC LIQUID FUELS ON THE TERRITORY OF PRIMORSKY KRAI

DOI: http://dx.doi.org/10.18796/0041-5790-2018-2-54-60

\section{Author}

Bakurova E.V.'

${ }^{1}$ The Far Eastern Federal University, Vladivostok, 690090, Russian Federation

\section{Authors' Information}

Bakurova E.V., Applicant of School of economy and management, tel.: +7 (914) 791-70-71, e-mail: bakurovs@yandex.ru

\section{Abstract}

Modern coal industry is not only coal mining, it is an innovative processing production and breakthrough technologies. Special attention should be paid to the development of production of deep processing of coal, increase the export of products with high added value. The important role belongs to public-private partnership as a form of cooperation between state bodies and private business in implementation of large-scale socially significant projects. The article shows the possibility of implementing an innovative approach to the development of the coal industry of Primorsky region with using of public-private partnerships.

Figures:

Fig. 1. Mechanism of coal processing into coal oil project implementation under the state-private partnership in the Primorski Krai territory

Fig. 2. Project efficiency indicators dependence on the state investment share with tax exemption granting to the Priority Social and Economic Development Areas

\section{Keywords}

Public-private partnership (PPP), Coal, Innovative development of enterprises of coal industry, Coal processing, Synthetic liquid fuel (CTL), Project of processing of coal into synthetic liquid fuel, Primorsky Krai, Structuring of PPP projects.

\section{References}

1. Plakitkina L.S. Intensifikacija innovacionnogo processa $v$ ugol'noj promyshlennosti Rossii [Intensification of the innovation process in industrial coal industry of Russia]. Gornaja Promyshlennost' - Mining Industry, 2011, No. 3, pp. 4-11.

2. Kretinina T.V. Faktory jekonomicheskogo rosta v postdepressivnom ug ledobyvajushhem regione: vozmozhnosti i jeffektivnost' gosudarstvennochastnogo partnerstva [Factors of economic growth in postdepression ug- ledobychayuschem region: opportunities and effectiveness of public-private partnership]. Inzhenernyj vestnik Dona - Engineering journal of Don, 2011, Vol. 17(3), pp. 285-293.

3. Nikitenko S.M. \& Goosen E.V. Kompleksnoe osvoenie prirodnyh resursov na principah gosudarstvenno-chastnogo partnjorstva [The integrated development of natural resources on the principles of public-private partnership]. Gornyy Informatsionno-Analiticheskiy Byulleten - Mining Information-Analytical Bulletin, 2015, No. 1-2, pp. 150-159.

4. Bakurova E.V. Pererabotka uglej v sinteticheskoe zhidkoe toplivo kak strategicheskoe napravlenie razvitija predprijatij ugol'noj otrasli Primorskogo kraja [Processing of coal into synthetic liquid fuels as a strategic direction of development of enterprises of coal industry of Primorsky Krai]. Ugol' - Russian Coal Journal, 2016, No. 10, pp. 46-50. Available at: http://www.ugolinfo.ru/ Free/102016.pdf (accessed 15.01.2018).

5. Shumejko M.V. Gidrogenizacija uglja [Hydrogenation of coal]. Gornyy Informatsionno-Analiticheskiy Byulleten - Mining Information-Analytical Bulletin, 2008, No. 9, pp. 32-39.

6. Proekt proizvodstva 500 tys. $t$ motornogo topliva iz uglja [The project of production of 500 thousand tons of motor fuels from coal]. Web-resource. Availaible at: http://www.uglerodtophim.ru/2010-10-08-13-37-44/24 (accessed 15.01.2018).

7. Merzlov I.Yu. Podhody k strukturirovaniju proektov gosudarstvenno-chastnogo partnjorstva [Approaches to structuring public-private partnerships]. Voprosy regulirovanija jekonomiki - The issues of regulation of the economy, 2014, Vol. 5(1), pp. 77-87.

8. Bakurova E.V. Social'no-jekonomicheskie aspekty realizacii proekta pererabotki uglej v sinteticheskoe zhidkoe toplivo na territorii Primorskogo kraja [Socio-economic aspects of the project of processing coal into synthetic liquid fuels on the territory of Primorsky region]. Izvestija Dal'nevostochnogo federal'nogo universiteta - Proceedings of the Far Eastern Federal University, 2016, No. 1, pp. 100-115.

\section{СУЭК - лидер социального развития России}

17 января 2018 2. Российский союз промышленников и предпринимателей (РСПП) объявил итоги авторитетного ежегодного российского конкурса «Лидеры российского бизнеса: динамика и ответственность - 2017». АО «СУЭК» стало обладателем гран-при конкурса в номинации «За вклад в социальное развитие территорий».

АО «СУЭК»- один из признанныхлидеров корпоративной социальной ответственности и благотворительности в стране. Основой социальной политики СУЭКАндрея Мельниченко являются комплексное повышение качества жизни в регионах, где расположены предприятия компании, создание благоприятной социальной среды в регионах присутствия.

Ежегодного СУЭК реализует порядка 150 социальных и благотворительных проектов в регионах своего присутствия. Объем социальных инвестиций компании составляет порядка 1 млрд руб.

Заместитель генерального директора СУЭК Сергей Григорьев подчеркивает: «СУЭК не только лидер угольной отрасли России и одна из крупнейших угольных ком- паний мира. Om стабильной работы наших предприятий зависит социальноэкономическая стабильность в нескольких регионах страны, в которых мы являемся крупнейшими налогоплательщиками и работодателями. Наш стратегический приоритет - всестороннее развитие регионов нашего присутствия, повышение качества жизни наших сотрудников, членов их семей, жителей на наших территориях. Это важное условие стабильного развития компании на многие годы вперед».

Всероссийский конкурс «Лидеры российского бизнеса: динамика и ответственность»- наиболее престижный конкурс по оценке динамики экономического и социального развития отечественных компаний. АО «СУЭК» неоднократно становилось победителем конкурса в различных номинациях, в том числе «За вклад в решение социальных проблем территорий», «За высокую социальную ответственность бизнеса», «За социальные программы поддержки семей», «За высокое качество отчетности в области устойчивого развития» и других. 


\section{Особенности культуры труда на японских предприятиях}

DOI: http://dx.doi.org/10.18796/0041-5790-2018-2-61-66

В статье представлены результаты стажировки руководителей, специалистов компании СУЭК и научных сотрудников НИИОГР на промышленных предприятиях Японии. Стажировка проводилась в рамках реализации ведомственной целевой программы «Повышение квалификации инженерно-технических кадров на 2016-2017 гг.». Описаны основные принципы формирования и особенности культуры труда, организации безопасной и эффективной трудовой деятельности на этих предприятиях, сделаны выводы о возможности применения японского опыта формирования культуры труда в практике работы российских предприятий угледобычи.

Ключевые слова: стажировка, организачия труда, эффективность, безопасность, качество и надежность, культура труда, установки и ценности персонала.

\section{ВВЕДЕНИЕ}

В настоящее время в $\mathrm{AO}$ «СУЭК» работа с персоналом направлена на формирование коллективов сотрудников, понимающих и разделяющих ценности и цели компании, профессионально подготовленных и мотивированных на производительную работу, стремящихся к саморазвитию. Развитие персонала рассматривается руководством компании как важная составляющая работы по формированию высокого уровня корпоративной культуры для обеспечения и сохранения лидирующих конкурентных позиций на рынке углепроизводителей [1, 2].

Составной частью выстраиваемой системы работы с кадровым резервом является организация зарубежных стажировок, каждая из которых позволяет ее участникам не только увидеть эффективные приемы труда, применяемые на зарубежных предприятиях, но и, адаптировав, освоить их в своей практике работы [3, 4].

В период 9-17 декабря 2017 г. состоялась командировка двадцати семи работников СУЭК и двух сотрудников НИИОГР на предприятия Японии, производящие карьерную и строительную технику. Согласно программе для участников стажировки было организовано посещение заводов компаний Hitachi и Komatsu с целью ознакомления с культурой труда в аспектах обеспечения эффективности и безопасности производства.

\section{КУЛЬТУРА ТРУДА}

Каждый из своего жизненного и трудового опыта знает, что одну и ту же работу можно сделать по-разному. Один работник выполнит работу (задание, операцию) качественно и быстро, другой - затратит уйму времени, устанет, а результат его труда «будет желать лучшего».

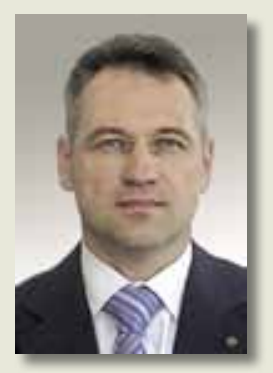

ФОМИН Анатолий Валентинович

Канд. сои. наук,

советник директора

по персоналу $A O$ «СУЭК»,

115054, г. Москва, Россия,

e-mail:FominAV@suek.ru

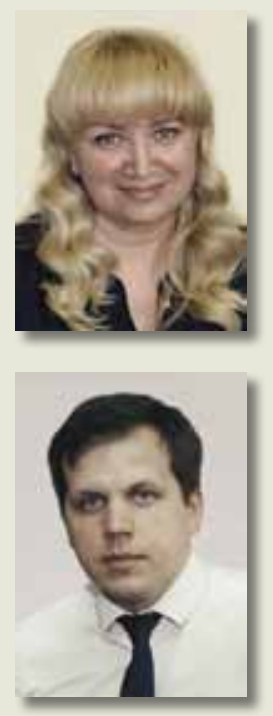

ЛАПАЕВА Оксана Анатольевна

Канд. экон. наук,

ученый секретарь НИИОГР,

старший научный сотрудник

Челябинского филиала

Института горного дела УрО РАН, 454048, г. Челябинск, Россия,

e-mail: lapaeva@yandex.ru

\section{СмолИН Антон Вячеславович}

Канд. техн. наук,

научный сотрудник НИИОГР,

454048, г. Челябинск, Россия,

e-mail: 89507358464@mail.ru

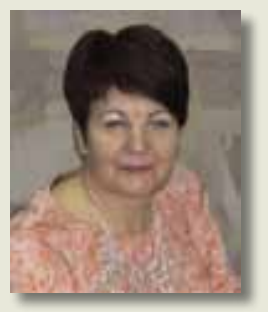

\author{
МИХНО Марина Владимировна \\ Директор Чегдомынского \\ горно-технологического техникума, \\ 682030, п. Чегдомын, \\ Хабаровский край, Россия, \\ e-mail: gildenbrant@mail.ru
}

Почему так происходит? Зачастую работники на предприятиях имеют различные представления о параметрах трудовой деятельности, ее организации, планировании, обеспечении безопасности, требованиях к состоянию рабочего места и различное отношение к труду. Все перечисленное определяется содержанием и состоянием культуры труда $[4,5,6,7]$.

Культура труда - это совокупность личностных и выработанных качеств работника, а также устройство предприятия, благодаря которому организуется и реализуется трудовая деятельность, обеспечивающая требуемый уровень безопасности и эффективности производства $[5,8,9]$. 


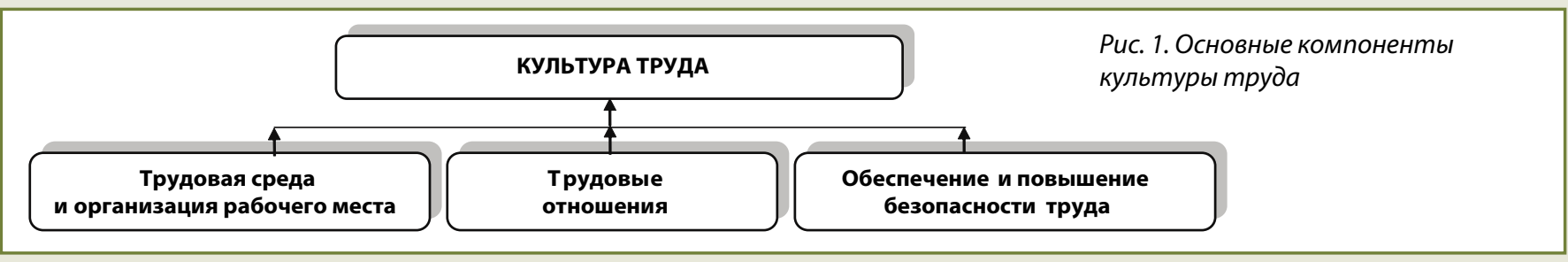

Традиционно культура труда на японских предприятиях ассоциируется во всем мире с понятием «качество», системой «5S», системой «кайдзен», «бережливым производством», кружками качества, системой пожизненного найма $[10,11]$. Но только ли этим формируется культура труда высокого уровня?

Попытаемся ответить на этот вопрос обобщением увиденного и услышанного на встречах с руководителями и специалистами заводов, в ходе посещения цехов предприятий.

Основные компоненты, определяющие уровень культуры труда и на которые обратили внимание участники стажировки на японских предприятиях, представлены на рисунке 1.

Формирование, поддержание высокой культуры труда и ее дальнейшее развитие на предприятиях компании Komatsu осуществляются в рамках реализации концепции управления «Путь KOMATSU» («KOMATSU Way»), основные положения которой отражены в документе Кодекс поведения Komatsu [12].

В основе этой концепции - принцип, определяющий жизнеспособность компании: «Максимизация корпоративной ценности путем достижения высокого качества и надежности продукции компании». Корпоративная ценность понимается в компании как доверие к ней общества и всех заинтересованных сторон, окружающих компанию (клиенты, партнеры и т.п.).

Основными составляющими реализуемой компанией концепции управления «KOMATSU Way» являются:

- эффективное корпоративное управление;

- эффективное и безопасное создание продукции;

- управление брэндом компании.

Главные принципы, заложенные в концепции управления компанией:

1. Сила компании - это жизнеспособность организации и всех ее сотрудников, непрерывные улучшения на каждом рабочем месте.

2. Работа лицом к клиенту с привлечением всего имеющегося потенциала организации.

3. Соблюдение баланса жизненного цикла работника (работа/отдых).

\section{- Трудовая среда и организация рабочего места}

Основной принцип организации трудового процесса на предприятиях - обеспечение качественного и надежного производственного процесса. Для этого используются организационные инструменты, позволяющие сократить дефекты, брак, отходы и переделки исправляемого брака. Эти инструменты объединены в методику под названием Дзидока (jidoka), которая включает в себя:

1. защиту от ошибок / защиту от непреднамеренного использования - технические и технологические решения, реализация которых позволяет сделать операцию только одним, правильным способом и дефект просто не может образоваться;
2. автоматизацию трудовых операций - создание и использование такого оборудования, которое способно самостоятельно обнаруживать первый дефект, после чего сразу остановиться и сигнализировать о том, что возникла проблема;

3. поиск причины возникновения дефекта;

4. контроль источника ошибок - перенос фокуса контроля с готовой продукции на процесс;

5. организационную и операционную стандартизацию - доступное для работника описание правильного выполнения критичных и важных с точки зрения качества операций [14].

Следует отметить, что принимавшие нас руководители и специалисты японских предприятий отмечали: количество дефектов, равное «нулю», - это сказка, так и не ставшая былью. Попытки создать систему, полностью исключающую брак во всех его проявлениях и на всех стадиях производственного процесса, потерпели крах, в некоторых случаях вместе с компаниями, реализующими такие системы. Реальная цель работы в этом направлении - ноль брака у потребителя, отсутствие повторяющихся дефектов и минимальный уровень брака в системе. Контроль качества осуществляется самим рабочим, выполняющим операции, и при необходимости контролерами по завершении сборки крупных узлов машин.

По сути, обеспечение производительного труда реализуется в двух направлениях: первое - обеспечение отсутствия дефектов у потребителя, т.е. обнаружение дефекта до отгрузки продукции; второе - выстраивание качественного производственного процесса.

Японские менеджеры признают, что выстраивание качественного производственного процесса трудоемко, требует целенаправленной непрерывной работы и ресурсов на первоначальном этапе, но оно того стоит (рис. 2).

Основной принцип, заложенный на японских предприятиях в мотивацию работника к качественному труду без дефектов, - это «не принимай; не производи; не передавай дефекты». Принцип реализуется благодаря созданию защиты от ошибок.

Например, при сборке на узле имеются два одинаковых отверстия. Если рабочий вставит трубку в одно отверстие будет правильно (рис. 3), вставит в другое - будет брак, который определится только на последующей операции или вообще на финишной. Так как изделие жестко закрепляется на сборочном стенде, одно из отверстий закрыто пластиной и по ошибке трубку туда точно не вставишь.

Установление причины и источника брака, разработка решения по его устранению, реализация решения и отработка в технологии выполнения операций позволяют забыть про брак навсегда.

В случаях, когда подобное техническое решение невозможно, используется организационная и операционная стандартизация. Для этого все операции, производимые 
для выпуска продукции, делятся на 4 категории по их влиянию на качество (табл. 1), и для каждой из них определяется требуемый уровень стандартизации. По всем критичным для качества продукции операциям работнику четко указываются правильные действия (рис. 4).

\section{- Трудовые отношения}

Практически на всех предприятиях нам удалось увидеть другое отношение к бракам, дефектам, ошибкам персонала и к качеству труда, чем на отечественных предприятиях (табл. 2).

Отношение к дефектам на японских предприятиях следующее: промахи из-за забывчивости, случайной перестановки, перепутывания, неправильного считывания, ложной интерпретации, заблуждений, незнания или невнимательности возможны и неизбежны; их следует вскрывать и нельзя замалчивать [14].

Основной принцип, реализуемый в целенаправленной работе с дефектами в технологии, организации, управлении, поведении и действиях работников, - «необходимо искать не виновников дефекта, а его причину». Причины дефектов определяются по следующей цепочке: дефект, возникший в продукте - действие - сотрудник - причина - промах и/или заблуждение - дефект в системе. Таким образом, формируется и механизм предотвращения ошибок:

- создание условий для бездефектной работы;

- внедрение методов бездефектной работы;

- систематическое устранение возникших ошибок;

- принятие мер предосторожности и внедрение простых технических решений, позволяющих сотрудникам предотвратить совершение ошибки.

Следует отметить, что представленные в табл. 1 характеристики отношения работников к труду реализуются на японских предприятиях не только в аспекте обеспечения качества продукции, но и в аспекте обеспечения безопасности, поскольку ошибки оператора могут привести не только к браку, но и к травме [15].

Система обучения и подготовки работников в компании имеет несколько уровней. Основы трудовых отношений закладываются еще при обучении будущих работников в школе посредством проведения экскурсий по цехам предприятия, музею компании Komatsu. Компания осуществляет активную поддержку классов естественных наук в начальных школах. Следующим уровнем является помощь в получении базового образования, которая предоставляется людям, не имеющим возможности получить уровень
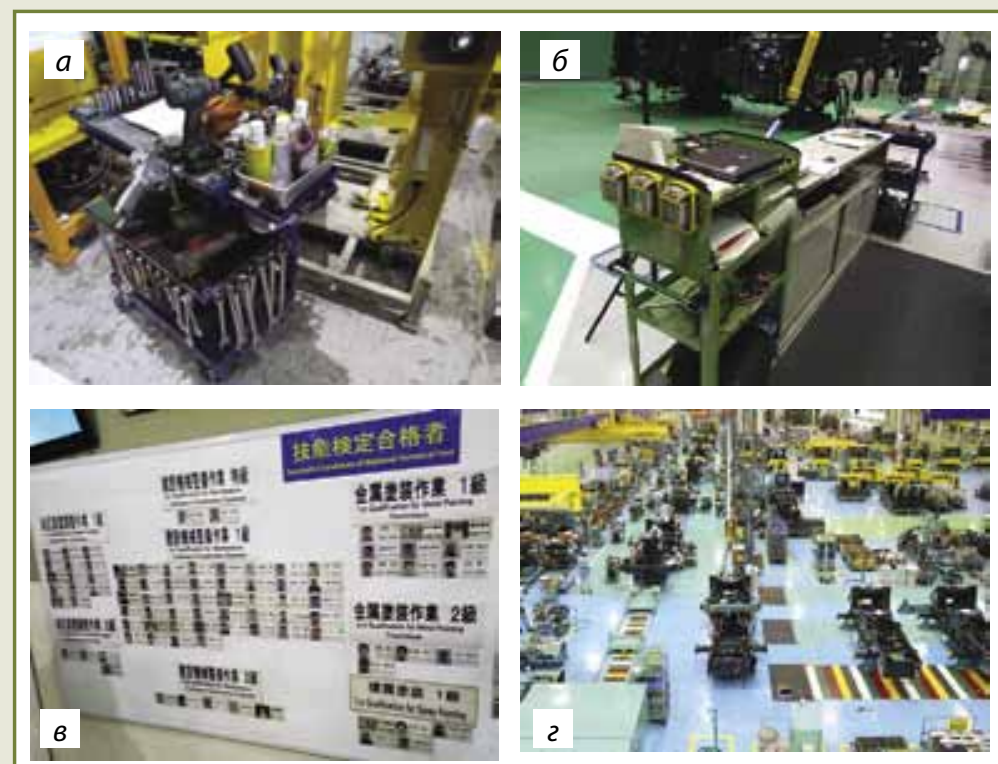

Рис. 2. Примеры организации труда на рабочем месте и в цехе: а - рабочее место рабочего; б -рабочее место мастера; в - визуализация структуры компетенций работников чеха; г-сборочный чех

Таблица 1

\section{Распределение операций по их влиянию на качество продукции (доработано по [14])}

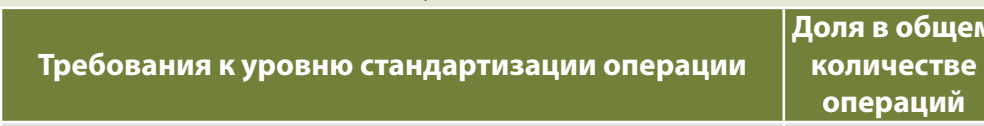

Критичная - должна быть описана очень четко $15 \%$

и последовательно, отклонения недопустимы

Очень важная - должна быть описана,

но допускаются отклонения, при этом мы

получаем хорошие результаты

Маловажная - правильное выполнение определено, но не описано, работа выполняется с очень большим допуском на отклонения, но это не влияет на результат Не важная - работу нужно сделать качественно

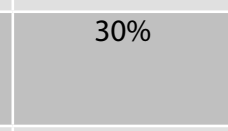

$30 \%$ образования, необходимый для найма на работу, в силу специфических для страны или региона обстоятельств (Чили, Африка) [12]. На следующем уровне предоставляется поддержка университе-

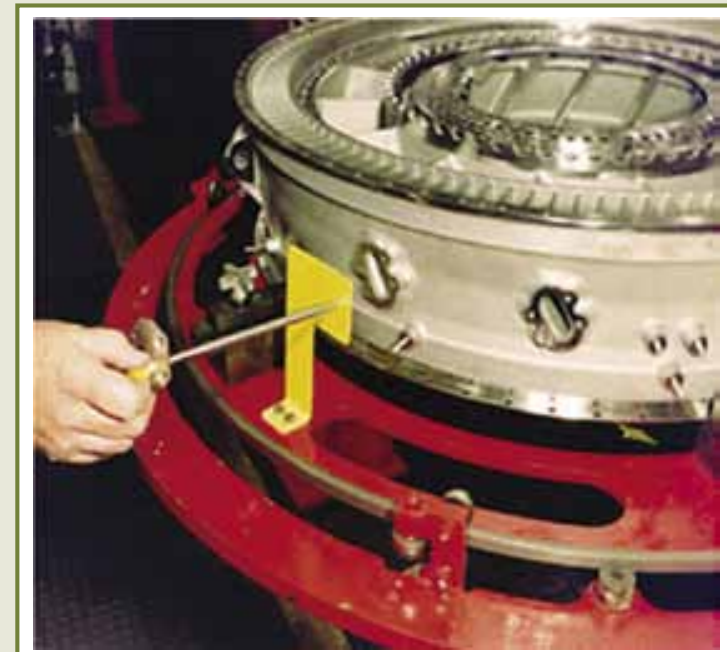

Puс. 3. Пример реализации системы защиты от ошибок [14] там и школам профессионального обучения - формирование учебной программы, предоставление оборудования Komatsu, a также инструкторов (рис. 5).

- Обеспечение и повышение безопасности труда

Культура безопасности труда на японских предприятиях является одним из важнейших элементов управления предприятием [15]. Культура безопасности труда рассматривается как понятие, включающее в себя следующие аспекты:

- отношение к безопасности труда;

ФЕВРАЛЬ, 2018, “УГОЛЬ" 

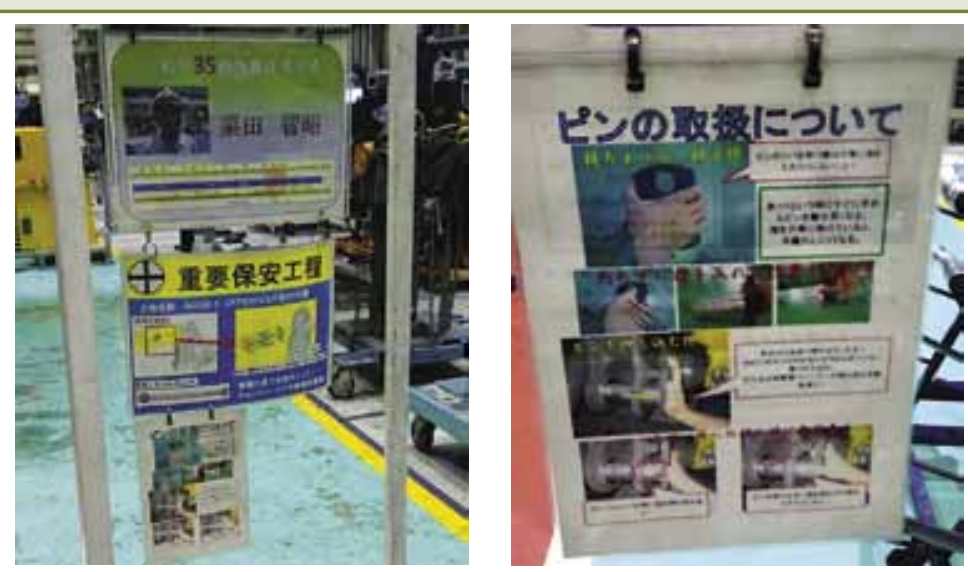

Рис. 4. Пример описания операции и ее правильного (безопасного) выполнения, размещенного на участке, где выполняется эта операчия

\section{Основные характеристики отношения работников к качеству труда на российских и японских предприятиях (доработано по [14])}

Российские предприятия

Брака должно быть меньше относительно уровня, достигнутого не планируют в прошедшем периоде Низкое качество продукции ошибка людей, сбой в работе оборудования

За качество ответственно производство (подразделение)

Качество есть результат проверок

Контроль качества - обязанность отдела контроля качества (ОТК)

Одни и те же дефекты могут повторяться

Ошибки выявляются контролерами
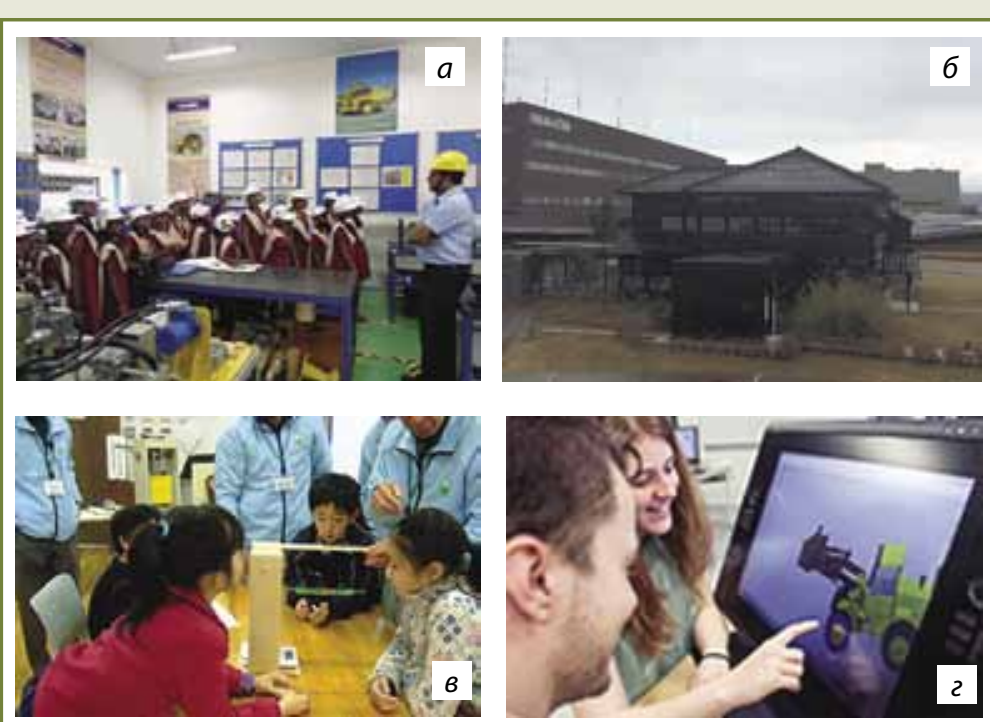

Рис. 5. Примеры участия компании в обучении и подготовке потенциальных работников [12]: а - экскурсия для школьников с разъяснением необходимости соблюдения правил безопасности; б - дом музей основателя компании Komatsи Мэитаро Такэути; в - объяснение школьникам основ конструирования деталей машин; г - предоставление оборудования для обучающих программ в университетах
- поведение в производственной системе;

- климат на рабочем месте с точки зрения безопасности труда $[12,16,17]$.

Отношение к безопасности труда как к основному и обязательному условию высокопроизводительной работы является обязательным критерием при отборе всего без исключения персонала (рабочих, специалистов и руководителей). Даже офисные работники, которые работают в безопасных, относительно производства условиях, допускаются до работы только после того, как смогут выявить 32 опасности на своем офисном рабочем месте. Считается, что работник должен не просто выучить, где может быть опасность, а должен ее чувствовать и уметь самостоятельно выявлять. На этом строится отношение к безопасности. Закрепляется это отношение при подготовке персонала, поддерживается коллективом при непосредственной реализации трудового процесса.

Такой многоэтапный подход к формированию и поддержанию внимательного отношения к безопасности труда обеспечивает и обосновывает безопасное поведение работников в производственном процессе. Поведение рабочих основывается на их собственном понимании существующих опасностей и соответствующих этим опасностям безопасных действий. Отдельного внимания заслуживают тренировочные центры при японских предприятиях, на которых рабочие отрабатывают не только правильные действия при работе с опасностями, но и могут ощутить на себе последствия от неправильных действий при типовых нарушениях требований безопасности. Так, например, в тренировочном центре компании Komatsu есть специальные стенды, на которых рабочие могут получить «псевдоопыт» травмирования без вреда для собственного здоровья (рис. 6.). Вход в центр сделан через низкий дверной проем, при прохождении которого, если смотреть только под ноги, ударишься головой. Тем самым акцентируется внимание рабочих на том, что опасность может быть везде, а не только там, где мы ее ждем. Представлен стенд, на котором работникам наглядно показывается нагрузка на коленные суставы при спрыгивании с высоты. Так при спрыгивании человека с небольшой, казалось бы, высоты (3 м) нагрузка на суставы достигает 400 кг. Тут же представлены все открытые вращающиеся части действующего на производстве оборудования, и работнику наглядно демонстрируется, что происходит с пластиковой рукой при попадании ее в опасную зону.

Руководству предприятий, которые мы посетили, удалось создать и поддерживать благоприятный климат на рабочем месте с точки зрения безопасности труда. В первую очередь это было достигнуто за счет того, что полностью отсутствует система наказаний за нарушения требований безопасности. Вместо наказаний работает общественное порицание коллектива. Такой подход позволяет практически полностью исключить сокрытие информации об опасностях и нарушениях. 

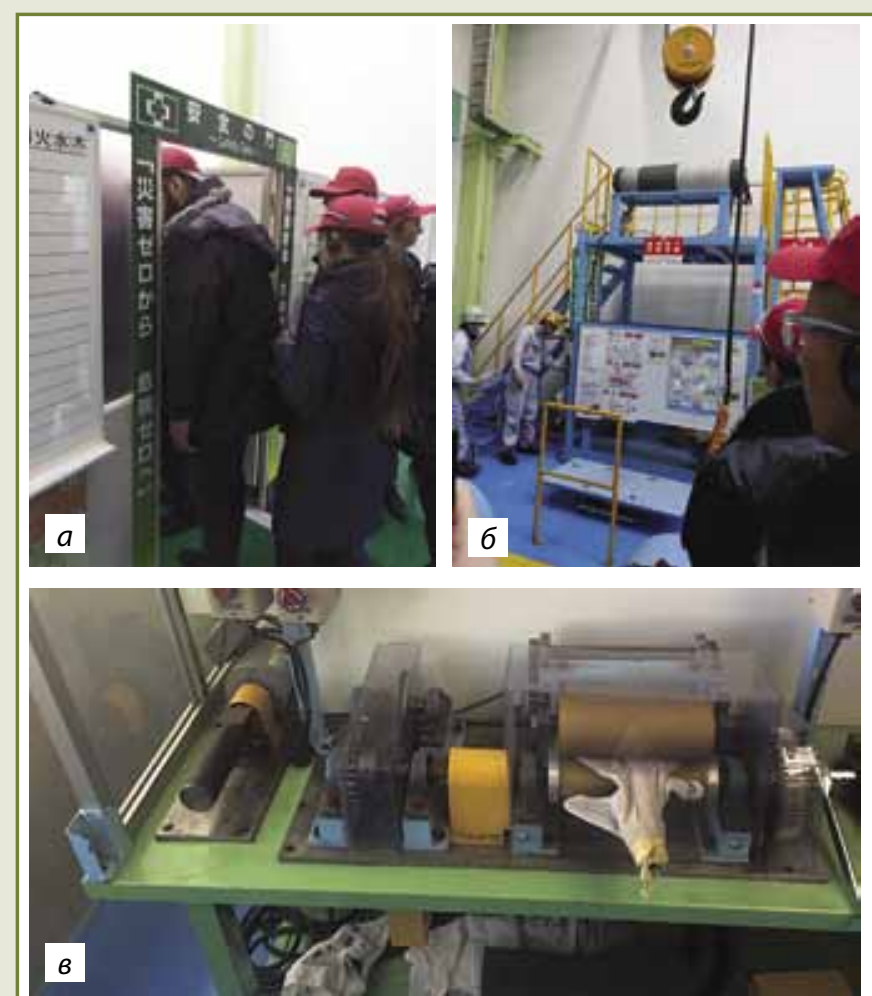

Puc. 6. Помещение учебного класса для отработки рабочими «псевдоопыта» ощущения опасности (учебный иентр Komatsu): a - проверка внимательности работника к высоте притолока двери; б-стенд, демонстрирующий нагрузку на суставы при падении работника с высоты 3 м и более; в-стенд, демонстрирующий последствия травмирования рабочих при работе в непосредственной близости с вращающимися частями узлов оборудования

Специалисты работают с этой информацией по следующему принципу: «Мы ищем не причины невыполнимости задачи, а возможные пути ее решения». Этим принципом мотивируется разработка технико-технологических решений. В случае, если нет возможности реализовать техникотехнологические решения, непосредственные руководители принимают и реализуют организационные решения, обеспечивающие безопасность труда, а на инструктажах подробно прорабатывают с рабочими все выявленные опасности и безопасные приемы труда.

Именно высокий уровень культуры безопасности труда на японских предприятиях позволяет им получать значимо более высокие результаты от применения общепринятых в мире методов и способов управления охраной труда (зафиксированных в стандартах OHSAS).

\section{ЗАКЛЮЧЕНИЕ}

Культура труда является важнейшей характеристикой успешно развивающейся компании, влияет на ее жизнеспособность, поскольку работники компании как носители культуры труда - основной источник ее развития.

В основу высокой культуры труда на японских предприятиях заложены принципы, нацеливающие всех сотрудников на поддержание и непрерывное повышение качества трудовых процессов и готовой продукции.

Одной из важных особенностей культуры труда работников японских предприятий является отношение к клиенту - отзывчивость на его потребности и включение всего потенциала компании для их удовлетворения. Цель тру- довой деятельности каждого работника - предоставлять продукты, услуги и решения, которые могут поддержать развитие бизнеса.

Достижение этой цели обеспечивается вовлечением каждого работника в процесс выстраивания безопасного и эффективного производственного процесса, поддержания требуемого ритма и такта движения ресурсов, не допускающего появления дефектов в технологии, организации, управлении, поведении и действиях людей. Для этого контроль качества результатов труда нацелен на выявление причины возникновения дефекта, а не его виновников.

Участники стажировки выражают благодарность руководству $А О$ «СУЭК», АО «СУЭК-Кузбасс», $А О$ «СУЭККрасноярск», АO «Разрез Тугнуйский», $A O$ «Ургалуголь», ООО «Приморскуголь», ООО «НИИОГР» и лично Ю.И. Албатову; представителям компаний: 000 «Комацу СНГ»С.Ю. Завивалову, А.М. Касаткину, ООО «Сумитек Интернейшнл»-г-ну Ю. Ютани, С.Н.Зыкову, Т. Отиука, ООО «Хитачи Констракшн Машинери Евразия»-2-ну М. Сэндзаки, ООО «Майнтек Машинери» - М. Четинелли и А.Ю. Загиеву за всестороннюю поддержку и организацию поездки.

\section{Список литературы}

1. Артемьев В.Б., Галкин В.А., Кравчук И.Л. Безопасность производства (организационный аспект). М.: Горная книга, 2016. 144 с.

2. Роль руководителя и персонала в обеспечении безопасности производства: Отдельная статья горного информационно-аналитического бюллетеня / В.Б. Артемьев, А.И. Добровольский, В.В. Лисовский, В.А. Галкин, А.М. Макаров, И.Л. Кравчук, Н.О. Каледина, О.В. Воробьева, А.В. Галкин. М.: Горная книга, 2017. 47 с. (Сер. «Б-ка горного инженера-руководителя». Вып. 32).

3. Об организации производства и труда на предприятиях Федеративной Республики Германии / А.В. Фомин, Д.Е. Горев, В.Ю. Натейкин, С.И. Захаров, В.А. Хажиев //Уголь. 2016. № 5. C. 86-89. URL: http://www.ugolinfo.ru/Free/052016. pdf (дата обращения: 15.01.2018).

4. Об организации производства и труда на предприятиях Японии / А.В. Фомин, О.Н. Садовая, М.Н. Полещук, О.С. Шивырялкина // Уголь. 2017. № 2. С. 30-33. URL: http://www. ugolinfo.ru/Free/022017.pdf (дата обращения: 15.01.2018).

5. Петров А.В., Карасева К.С. Основные теоретические подходы к исследованию современной корпоративной культуры труда // Вестник Санкт-Петербургского университета. Серия 12. 2015. Вып. 2. С. 86-92.

6. Гастев А.К. Трудовые установки / под ред. Ю. Гастева, Е. Петрова. 3-е изд. М.: Либроком, 2011. 480 с.

7. Culture Management // Management systems. URL: http://www.mgtsystems.com/culture-management-dif (дата обращения: 15.01.2018).

8. Custom the Relationship between Leadership Styles and Organizational Culture essay paper sample // Best writing service. URL: http://bestwritingservice.com/essays/ Management/the-relationship-between-leadership-stylesand.html (дата обращения: 15.01.2018).

9. Камерон К., Куинн Р. Диагностика и изменение организационной культуры / пер. с англ. под ред. И.В. Андреевой. СПб.: Питер, 2001. 320 с.

10. Галева А.А. Особенности организационной культуры в японских и немецких компаниях // Культура в современ- 
ном мире. 2015. № 1. [Электронный ресурс]. URL: http:// infoculture.rsl.ru (дата обращения 15.01.2018).

11. Kristina Kovacevik. The use of brainwashing in the process of changing the organizational culture of the German and Japanese workers // Ekonomiski Razvoj - Economic Development. 2013. Issue 3. P. 243.

12. Официальный сайт компании Komatsu Ltd [Электронный ресурc]. URL: https://home.komatsu/en/ (дата обращения: 15.01.2018).

13. Розенко Н. Дзидока, или Правильный процесс дает правильные результаты [Электронный ресурc]. URL: http:// www.cfin.ru/management/manufact/jidoka.shtml (дата обращения: 15.01.2018).
14. http://www.careerjoy.com/ [Электронный ресурс]. URL: http://www.careerjoy.com/blog/mmm-3-principles-ofjapanese-ork-culture-monday-morningmotivator/.

15. Comparing safety culture and learning culture five starsLittlejohn, Allison; Lukic, Dane; Margaryan, Anoush Risk Management 2014-11-01.

16. Safety Culture And Best Practices At Japan's Fusion Research ...five stars / K. Rule, L. Cadwallader, M. King, Y. takase, Y. Oshima, K. Nishimura and A. Sukegawa Prepared for the U.S. Department of Energy under Contract DE-AC02.

17. Stiglitz J.E., Greenwald B.C. Creating a Learning Society: A New Approach to Growth, Development, and Social Progress. New-York: Columbia Univ Pr., 2014. 680 p.

UDC 658.382:658.387:658.5(520) ๔ A.V. Fomin, O.A. Lapaeva, A.V. Smolin, M.V. Mikhno, 2018

PRODUCTION SETUP

ISSN 0041-5790 (Print) • ISSN 2412-8333 (Online) • Ugol' - Russian Coal Journal, 2018, № 2, pp. 61-66

Title

SPECIFIC FEATURES OF THE JAPANESE ENTERPRISES WORK CULTURE

DOI: http://dx.doi.org/10.18796/0041-5790-2018-2-61-66

\section{Authors}

Fomin A.V. ${ }^{1}$, Lapaeva O.A. ${ }^{2,3}$, Smolin A.V. ${ }^{2}$, Mikhno M.V. ${ }^{4}$

'SUEK, JSC, Moscow, 115054, Russian Federation

${ }^{2}$ Institute of efficiency and safety of mining production ("NIIOGR" LLC), Chelyabinsk, 454048, Russian Federation

${ }^{3}$ Chelyabinsk Mining Institute of Ural branch of RAS, Chelyabinsk, 454048, Russian Federation

${ }^{4}$ Chegdomyn Mining and Technological College, Chegdomyn village, Khabarovsk Krai, 682030, Russian Federation

\section{Authors' Information}

Fomin A.V., PhD (Sociological Sciences), Adviser, Director in charge of Human Resources, e-mail: FominAV@suek.ru

Lapaeva O.A., PhD (Economic), Academic Secretary, Senior Scientific Assistant, e-mail: lapaeva@yandex.ru

Smolin A.V., PhD (Engineering), Scientific Assistant, e-mail: 89507358464@mail.ru

Mikhno M.V., Director, e-mail: gildenbrant@mail.ru

\section{Abstract}

The paper presents the results of SUEK managers and NIIOGR scientific researchers practical training in Japan industrial enterprises. The practical training was performed as part of the departmental target program "Engineering and technical personnel qualification improvement in 2016-2017". The main concepts of the labor culture formation and its specific features, safe and efficient labor activity organization at these enterprises are described, conclusions are made on the possibility of the Japanese experience application for labor culture forming in the Russian coal mining enterprises.

\section{Keywords}

Practical training, Labor organization, Efficiency, Safety, Quality and reliability, Labor culture, Personnel resolutions and values.

\section{References}

1. Artemiev V.B., Galkin V.A. \& Kravchuk I.L. Bezopasnost' proizvodstva (organizatsionnyy aspect) [Industrial safety (organizational aspect]. Moscow, Gornaya Kniga Publ., 2016, 144 p.

2. Artemiev V.B., Dobrovolskiy A.I., Lisovskiy V.V., Galkin V.A., Makarov A.M., Kravchuk I.L., Kaledina N.O., Vorobyova O.V. \& Galkin A.V. Rol rukovoditelya i personala vobespechenii bezopasnostiproizvodstva [Manager's and personnel role in production safety provision]. Separate article in the Mining Information and Analytical Bulletin. Moscow, Gornaya Kniga Publ., 2017, 47 p. (Mining Engineer-Manager's Library series, issue 32)

3. Fomin A.V., Gorev D.E., Nateikin V.Yu., Zakharov S.I. \& Khazhiev V.A. Ob organizatsii proizvodstva i truda na predpriyatiyakh Federativnoy Respubliki Germanii [On production and labor organization in Germany enterprises]. Ugol' - Russian Coal Journal, 2016, No. 5, pp. 86-89. Available at: http://www. ugolinfo.ru/Free/052016.pdf (accessed 15.01.2018).

4. Fomin A.V., Sadovaya O.N., Poleshchuk M.N. \& Shivyryalkina O.S. Ob organizatsii proizvodstva i truda na predpriyatiyakh Yaponii [On production and labor organization in the enterprises of Japan]. Ugol' - Russian Coal Journal, 2017, No. 2, pp. 30-33. Available at: http://www.ugolinfo.ru/Free/022017.pdf (accessed 15.01.2018).
5. Petrov A.V. \& Karaseva K.S. Osnovnye teoreticheskie podhody k issledovaniyu sovremennoy korporativnoy kultury truda [Main theoretical to the modern corporate labor culture investigation]. Vestnik Sankt-Peterburgskogo Universiteta-Newsletter of the St-Petersburg Universtity, Series 12, 2015, issue 2, pp. 86-92.

6. Gastev A.K. Trudovye ustanovki [Labor resolutions]. Under the editorship of Gastev Yu., Petrov E., 3-d edition. Moscow, Librokom Publ., 2011, 480 p.

7. Culture Management. Management systems. Web-resource. Availaible at: http://www.mgtsystems.com/culture-management-dif (accessed 15.01.2018). 8. Custom the Relationship between Leadership Styles and Organizational Culture essay paper sample. Best writing service. Web-resource. Availaible at: http://bestwritingservice.com/essays/Management/the-relationshipbetween-leadership-styles-and.html (accessed 15.01.2018).

9. Cameron K. \& Quinn R. Diagnostika i izmenenie organizatsionnoy kultury [Organization culture diagnostics and transformation]. Translated from English under the editorship of Andreyeva I.V. St-Petersburg, Piter Publ., 2001, 320 p. 10. Galeva A.A. Osobennosti organizatsionnoy kultury v yaponskih i nemetskih kompaniyah [Specific features of organizational culture in Japanese and German companies]. Kultura $v$ sovremennom mire - Culture in the Modern World, 2015, No. 1. Web-resource. Available at: http://infoculture.rsl.ru (accessed 15.01.2018).

11. Kristina Kovacevik. The use of brainwashing in the process of changing the organizational culture of the German and Japanese workers. Ekonomiski Razvoj-Economic Development, 2013, No. 3, pp. 243.

12. Official website Komatsu Ltd. Web-resource. Availaible at: https://home. komatsu/en/ (accessed 15.01.2018).

13. Rozenko N. Dzidoka, ili Pravil'nyy protsess daet pravil'nye rezul'taty [Dzidoka, or the Correct process yields the correct results]. Web-resource. Availaible at: http://www.cfin.ru/management/manufact/jidoka.shtml (accessed 15.01.2018).

14. http://www.careerjoy.com/ Web-resource. Availaible at: http://www. careerjoy.com/blog/mmm-3-principles-of-japanese-ork-culture-mondaymorningmotivator/ (accessed 19.02.2015).

15. Comparing safety culture and learning culture five starsLittlejohn, Allison; Lukic, Dane; Margaryan, Anoush Risk Management 2014-11-01.

16. Rule K., Cadwallader L., King M., Takase Y., Oshima Y., Nishimura K. \& Sukegawa A. Safety Culture and Best Practices at Japan's Fusion Research ...five stars. Prepared for the U.S. Department of Energy under Contract DE-AC02. 17. Stiglitz J.E. \& Greenwald B.C. Creating a Learning Society: A New Approach to Growth, Development, and Social Progress. New-York, Columbia Univ Pr., 2014, 680 p. 


\section{0 новой нормативной базе проблем борьбы с эндогенными пожарами в шахтах}

DOI: http://dx.doi.org/10.18796/0041-5790-2018-2-67-70

В статье приведены данные о возникновении эндогенных пожаров в шахтах Кузбасса. Рассмотрены введенные в действие в 2012-2016 гг. документы, составляющие нормативную базу защиты шахт от эндогенных пожаров на этапах их проектирования, строительства, отработки и ликвидации. По результатам рассмотрения сделан вывод о соответствии новой нормативной базы современным достижениям науки и практики и возможности снижения эндогенной пожароопасности шахт при ее реализации. Предложены меры по совершенствованию эндогенной пожаробезопасности шахт путем гармонизации использованных терминов и определений основных понятий и обновления устаревших в настоящее время актов рекомендательного характера (руководств, методик, технологических схем и др.).

Ключевые слова: подземная добыча угля, эндогенная пожароопасность, промышленная безопасность, федеральные нормы и правила, самовозгорание угля, нормативная база, неразрушаюший контроль, взрывоустойчивая перемычка.

\section{ВВЕДЕНИЕ}

В условиях рыночной экономики естественной задачей является обеспечение рентабельности шахт. Большим потенциальным резервом в решении данной задачи является снижение аварийности с одновременным повышением нагрузки на очистные забои и концентрацией горных работ.

В связи с этим борьба с эндогенными пожарами в шахтах приобрела особую значимость. Как показывает опыт Кузбасса, при больших суточных нагрузках обострились традиционно разнонаправленные меры профилактики самовозгорания угля и преодоления «газового барьера». Эндогенные пожары стали возникать при скоростях подвигания 190 м/мес. и отсутствии потерь на пластах, ранее не отнесенных к склонным к самовозгоранию. Примером является самовозгорание угольной пыли у газоотсасывающей скважины на пласте Толмачевском (шахта «Полысаевская», 2011 г.). Ее общая масса, вынесенная в выработанное пространство, превысила 11 т.

\section{НОВАЯ НОРМАТИВНАЯ БАЗА}

Задача повышения рентабельности подземной добычи угля в годы реструктуризации в Кузбассе решалась ликвидацией наиболее аварийных шахт. Иллюстрацией этому могут служить данные о возникновении эндогенных пожаров, приведенные в таблице.

Статистика свидетельствует о том, что влияние фактора реструктуризации отрасли на снижение числа эндо-

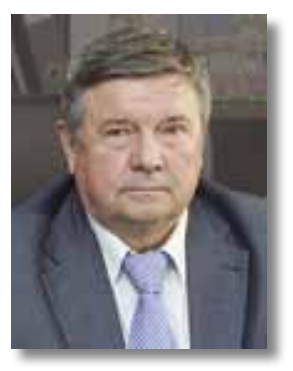

ФИЛАТОВ Юрий Михайлович

Канд. техн. наук, генеральный директор AО «НЦ ВостНИИ», 650002, г. Кемерово, Россия, тел.: +7 (3842) 64-30-99, e-mail:main@nc-vostnii.ru

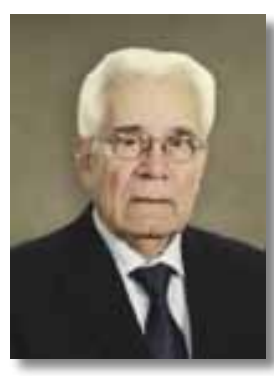

ИГИШЕВ Виктор Григорьевич Доктор техн. наук, профессор, научный консультант AО «НЦ ВостНИИ», 650002, г. Кемерово, Россия, тел.: +7 (3842) 64-30-99, e-mail:main@nc-vostnii.ru

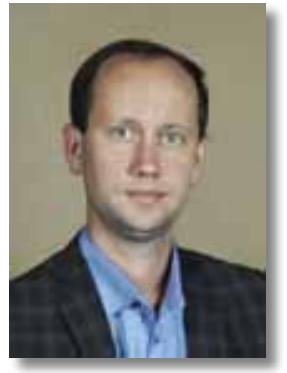

\section{ШЛАПАКОВ Павел Александрович} Заведующий лабораторией профилактики эндогенных пожаров AO «НЦ ВостНИИ», 650002, г. Кемерово, Россия, тел.: +7 (950) 579-59-96, e-mail:shlapak1978@mail.ru

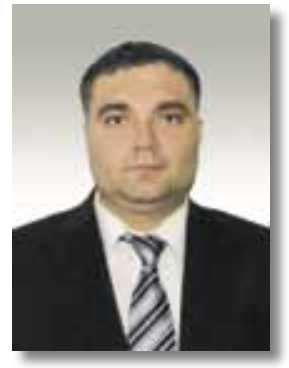

\section{ШИРЯЕВ Сергей Николаевич}

Технический директор ООО «Управляющая компания «ЕВРАЗ Междуреченск», 654080, г. Междуреченск, Россия, тел.: +7 (960) 931-37-95, e-mail:Sn_shir@mail.ru

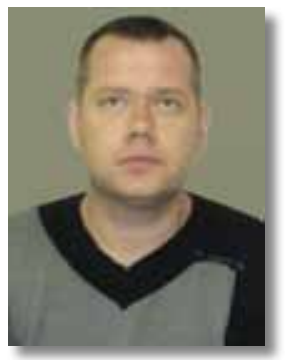

ШЛАПАКОВ Евгений Александрович Научный сотрудник лаборатории профилактики эндогенных пожаров AO «НЦ ВостHИИ», 650002, г. Кемерово, Россия, тел.: +7 (923) 510-37-21 
Динамика эндогенных пожаров в шахтах Кузбасса, 1992-2016 rr.

\begin{tabular}{|c|c|c|}
\hline Год & Число пожаров & Всего пожаров \\
\hline 1992 & 29 & \multirow{5}{*}{94} \\
\hline 1993 & 16 & \\
\hline 1994 & 17 & \\
\hline 1995 & 13 & \\
\hline 1996 & 19 & \\
\hline 1997 & 8 & \multirow{5}{*}{36} \\
\hline 1998 & 12 & \\
\hline 1999 & 7 & \\
\hline 2000 & 3 & \\
\hline 2001 & 6 & \\
\hline 2002 & 2 & \multirow{5}{*}{21} \\
\hline 2003 & 6 & \\
\hline 2004 & 8 & \\
\hline 2005 & 2 & \\
\hline 2006 & 3 & \\
\hline 2007 & 3 & \multirow{5}{*}{15} \\
\hline 2008 & 2 & \\
\hline 2009 & 2 & \\
\hline 2010 & 4 & \\
\hline 2011 & 4 & \\
\hline 2012 & 7 & \multirow{5}{*}{14} \\
\hline 2013 & 5 & \\
\hline 2014 & 1 & \\
\hline 2015 & 1 & \\
\hline 2016 & - & \\
\hline
\end{tabular}

генных пожаров к 2001 г. было практически исчерпано. Дальнейшее снижение числа пожаров обеспечили существовавшие в те годы нормативная база, научное обеспечение, техническая оснащенность и производственная дисциплина. Вместе с тем, достигнутый к 2006 г. уровень снижения эндогенной пожароопасности не удовлетворял запросов производства. В 2012 г., например, из-за самовозгорания угля были изолированы два комплексномеханизированных забоя с суммарной производительностью 9800 т/сут. При этом один забой проветривался по комбинированной схеме (шахта «Заречная»), второй - по прямоточной (ш/у «Анжерское»).

Стала очевидной необходимость анализа основных положений защиты шахт от самовозгорания угля, и ее совершенствования с учетом негативного влияния факторов, сопутствующих работе высокопроизводительных забоев (увеличение количества воздуха, газоуправление через выработанное пространство, вынос пыли в отработанную часть пласта и другое). Прежде всего это коснулось нормативной базы, переработка которой выполнена в 2012-2016 гг.

В «Положении об аэрогазовом контроле в угольных шахтах» [1], изданном в 2012 г., регламентированы: контроль параметров рудничной атмосферы в целях обнаружения подземных пожаров, методика расчета воздуха и выделяемого оксида углерода и методика определения индикаторных газов.
В 2012 г. также вступила в действие «Инструкция по применению схем проветривания выемочных участков шахт с изолированным отводом метана из выработанного пространства с помощью газоотсасывающих установок» [2]. В ней впервые законодательно регламентировано проведение газоотводящих сбоек и скважин на расстоянии, равном 2/3 планируемого подвигания линии очистного забоя за инкубационный период самовозгорания угля.

Данное требование обусловлено необходимостью снижения длительности отработки активно проветриваемой зоны в выработанном пространстве. Это позволяет минимизировать время поступления кислорода к разрыхленным массам угля, образующимся вследствие отжима краевых частей оконтуривающих лавы угольных целиков. Создается возможность предотвращения перерастания низкотемпературного окисления угля в стадию самонагревания ввиду недостаточности кислорода.

С 2013 г. задействована «Инструкция по определению инкубационного периода самовозгорания угля» [3]. Использование данного нормативного документа позволило установить единый порядок определения склонности угля к самовозгоранию на всей территории России и исключить применение нелегитимных методик.

В 2016 г. в нее были внесены изменения в части категорирования угля по склонности к самовозгоранию. В действующей редакции исключено понятие «уголь, весьма склонный к самовозгоранию». Внесение этого изменения обусловлено необходимостью исключения разночтений действующих федеральных норм и правил при выборе средств и способов профилактики самовозгорания, применяемых на угольных предприятиях, разрабатывающих пласты угля, склонного к самовозгоранию. Фактически средства и способы профилактики самовозгорания угля для «склонных» и «весьма склонных» углей не имеют принципиальных различий.

С 2015 г. действует «Инструкция по изоляции неиспользуемых горных выработок и выработанных пространств в угольных шахтах» [4]. Необходимость разработки данного нормативного документа была продиктована тем, что существовавшее с 1977 г. «Руководство по изоляции отработанных участков, временно остановленных и неиспользуемых горных выработок в шахтах» уже не соответствовало произошедшим изменениям геологических условий и технологии горных работ. Кроме того, оно не имело законодательного статуса. В таких условиях органам Госгортехнадзора не представлялось возможным осуществлять объективный контроль качества и своевременности изоляции, что снижало эффективность профилактики эндогенных пожаров.

Одним из основных требований инструкции [4] предусматривается изоляция горных выработок на пластахугля, склонного к самовозгоранию, взрывоустойчивыми перемычками. Это обусловлено необходимостью взрывозащиты действующих горных выработок в случае возникновения эндогенного пожара в выработанном пространстве и возможности последующего взрыва метановоздушной смеси.

Также данной инструкцией предусмотрен неразрушающий контроль прочностных параметров взрывоустойчивых перемычек. Необходимость неразрушающего кон- 
троля вызвана тем, что материалы, применяемые при возведении взрывоустойчивых перемычек, требуют неукоснительного соблюдения технологии. Так, при изменении температуры используемой воды или соотношения количества смеси с водой возможно значительное ухудшение взрывозащитных свойств возводимой перемычки. На практике обнаруживались перемычки, не набравшие расчетной прочности в установленный период.

К сожалению, в настоящее время методика неразрушающего контроля взрывоустойчивых перемычек так и не создана, в то время как в строительстве используются приборы для контроля качества бетонных изделий. Данные приборы после приведения их во взрывобезопасное исполнение и получения всех необходимых разрешительных документов в полной мере позволили бы решить указанную проблему. Заводы-изготовители данных приборов готовы приступить к выпуску и сертификации при условии заказа значительных партий. Для этого необходимо решить вопрос финансирования.

В новые «Правила безопасности в угольных шахтах» [5], изданные в 2015 г., внесены изменения в части вскрытия и подготовки склонных к самовозгоранию угольных пластов. Существовавший ранее запрет на вскрытие последних пластовыми выработками вступал в противоречие с наличием значительного количества шахт, где данное требование выполнено не было. К тому же за последние 15 лет в Кузбассе зафиксировано только два случая самовозгорания угля во вскрывающих выработках. При этом в ходе расследования данных аварий было установлено, что пожары возникли из-за отступлений от проектных решений и невыполнения мер по предупреждению самовозгорания угля.

Издание в 2016 г. «Инструкции по предупреждению эндогенных пожаров и безопасному ведению горных работ на склонных к самовозгоранию пластах угля» [6] завершило формирование новой нормативной базы. С учетом требований, зафиксированных в этой инструкции, было скорректировано деление пластов по склонности к самовозгоранию на две категории (склонные, несклонные) и разрешено пластовое вскрытие склонных к самовозгоранию шахтопластов.

Необходимо отметить, что инструкции [6] впервые в угольной отрасли придан общероссийский статус. До 2016 г. в шахтах России действовали периодически перерабатываемые бассейновые инструкции. Зачастую они решали задачу защиты шахт от эндогенных пожаров с учетом технического и финансового обеспечения шахт.

Введение в действие новой единой инструкции, как и всей нормативной базы, делает возможным формирование комплекса мер, эффективных при реализации в любых горно-геологических и горнотехнических условиях. В свою очередь она позволяет контролирующим органам использовать в своей работе нормативные требования, гармонично связывающие отдельные этапы борьбы с эндогенными пожарами: прогноз, профилактику, обнаружение, локацию и тушение.

\section{ЗАКЛЮЧЕНИЕ}

Разработанные в 2012-2016 гг. нормативные документы, регламентирующие ведение горных работ на склонных к самовозгоранию пластах, базируются на современных до- стижениях науки и практики и при эффективном контроле в состоянии обеспечить снижение эндогенной пожароопасности шахт до приемлемого уровня. В частности в Кузбассе за последние три года (2014-2016 гг.) возникли два эндогенных пожара.

Однако возможности влияния созданной нормативной базы на проблему защиты шахт от самовозгорания могут быть увеличены за счет ее дальнейшего совершенствования.

В качестве первоочередной меры этого совершенствования может быть предложена гармонизация использованных в базе терминов и их определений. В частности в инструкциях [3] и [6] «инкубационный период самонагревания» и «инкубационный период самовозгорания», «ранняя стадия эндогенного пожара» трактуются как равнозначные с температурой $80-130^{\circ} \mathrm{C}$. В положении [1] «ранняя стадия пожара» характеризуется температурой тления, которая для угля может достигать более $290^{\circ} \mathrm{C}$. Ликвидация очагов самовозгорания при такой температуре потребует больших затрат технических и материальных средств.

Следующим этапом совершенствования нормативной базы является обновление устаревших в настоящее время документов, имеющих рекомендательный статус (руководства, методики, технологические схемы и другое). Отдельные из них, как, например, «Руководство по применению способов торможения развития самовозгорания угля в выработанном пространстве выемочных полей шахт», были разработаны в 1989 г., поэтому данное руководство, как и другие документы рекомендательного характера, должны быть переработаны в соответствии с существующими требованиями $[1,2,3,4,5,6]$.

\section{Список литературы}

1. Положение об аэрогазовом контроле в угольных шахтах. Сер. 05. Вып. 23. М.: ЗАО «Научно-технический центр исследований проблем промышленной безопасности» (ЗАО НТЦ ПБ), 2012. 110 с.

2. Федеральные нормы и правила в области промышленной безопасности «Инструкция по применению схем проветривания выемочных участков шахт с изолированным отводом метана из выработанного пространства с помощью газоотсасывающих установок». Сер. 05. Вып. 21. М.: ЗАО НТЦ ПБ, 2011. 126 с.

3. Федеральные нормы и правила в области промышленной безопасности «Инструкция по определению инкубационного периода самовозгорания угля». Сер. 05. Вып. 38. М.: ЗАО НТЦ ПБ, 2013. 22 с.

4. Федеральные нормы и правила в области промышленной безопасности «Инструкция по изоляции неиспользуемых горных выработок и выработанных пространств в угольных шахтах». Сер. 05. Вып. 43. М.: ЗАО НТЦ ПБ, 2015. 54 c.

5. Федеральные нормы и правила в области промышленной безопасности «Правила безопасности в угольных шахтах». Сер. 05. Вып. 40. М.: ЗАО НТЦ ПБ, 2015. 196 с.

6. Федеральные нормы и правила в области промышленной безопасности «Инструкция по предупреждению эндогенных пожаров и безопасному ведению горных работ на склонных к самовозгоранию пластах угля». Сер. 05. Вып. 46. М.: ЗАО НТЦ ПБ, 2016. 56 с. 
UDC 622.822.22 @ Yu.M. Filatov, V.G. Igishev, P.A. Shlapakov, S.N. Shiryaev, E.A. Shlapakov, 2018

ISSN 0041-5790 (Print) • ISSN 2412-8333 (Online) • Ugol' - Russian Coal Journal, 2018, № 2, pp. 67-70

Title

NEW REGULATORY FRAMEWORK FOR ENDOGENOUS FIRES PROBLEMS IN COAL MINES

DOI: http://dx.doi.org/10.18796/0041-5790-2018-2-67-70

Authors

Filatov Yu.M. ', Igishev V.G. ${ }^{1}$, Shlapakov P.A. ', Shiryaev S.N. ${ }^{2}$, Shlapakov E.A. ${ }^{\prime}$

1 "Scientific Centre "VostNII" for Industrial and Environmental Safety in Mining Industry" JSC, Kemerovo, 650002, Russian Federation

2"Upravlyayushchaya kompaniya "EVRAZ Mezhdurechensk" LLC, Novokuznetsk, 654080, Russian Federation

\section{Authors' Information}

Filatov Yu.M., PhD (Engineering), General Director, tel.: +7 (3842) 64-30-99, e-mail: main@nc-vostnii.ru

Igishev V.G., Doctor of Engineering Sciences, Professor, Scientific consultant, tel.: +7 (3842) 64-30-99, e-mail: main@nc-vostnii.ru

Shlapakov P.A., Laboratory Head, Laboratory for Prevention of Endogenous Fires, tel.: +7 (950) 579-59-96, e-mail: shlapak1978@mail.ru

Shiryaev S.N., Technical Director, tel.: +7 (960) 931-37-95, e-mail:Sn_shir@mail.ru Shlapakov E.A., Research worker of Laboratory for Prevention of Endogenous Fires, tel.: +7 (923) 510-37-21

\section{Abstract}

Information about the endogenous fires occurrence in the Kuzbass mines is given Federal rules and regulations enacted in 2012-2016, which has become the regulatory framework for mines protection from endogenous fires at the period of their design, construction, mining and abandonment are considered. Based on the results of the review, a conclusion was made on the compliance of the new regulatory framework with modern achievements of science and practices and the possibility of reducing the endogenous fire hazard in mines during its implementation. Measures for the endogenous fire safety improvement in coal mines of by harmonizing the used terms and defining the basic concepts and updating the currently outdated acts of recommendation (guidelines, methodologies etc.) are proposed.

\section{Keywords}

Underground coal mining, Endogenous fire hazard, Industrial safety, Federal rules and regulations, Coal ignition, Regulatory framework, Nondestructive test, Explosion-proof stopping.

\section{References}

1.Polozhenie ob aerogazovom kontrole vugolnykh shakhtakh [Regulation on air-gas control in coal mines]. Moscow, ZAO «Nauchno-tekhnicheskiy tsentr issledovaniy problem promyshlennoy bezopasnosti» (ZAO NTTS PB) Publ., 2012, Vol. 05(23), $110 \mathrm{p}$.

2. Federalnye normy i pravila v oblasti promyshlennoy bezopasnosti “Instruktsiya po primeneniyu skhem provetrivaniya vyemochnykh uchastkov shakht s izolirovannym otvodom metana iz vyrabotannogo prostranstva s pomoshch'yu gazootsasyvayushchikh ustanovok" [Instruction on the application of ventilation schemes of mines working areas with insulated removal of methane from the developed space using gas - suction plants]. Moscow, ZAO NTTS PB Publ., 2017, Vol. 05(21), 128 p. 3. Federal'nye normy i pravila voblastipromyshlennoy bezopasnosti"Instruktsiya po opredeleniyu inkubatsionnogo perioda samovozgoraniya uglya" [Instruction on the determination of the incubation period of coal combustion]. Moscow, ZAO NTTS PB Publ., 2013, Vol. 05(38), 22 p.

4. Federalnye normy i pravila v oblasti promyshlennoy bezopasnosti "Instruktsiya po izolyatsii neispol'zuemykh gornykh vyrabotok i vyrabotannykh prostranstv v ugol'nykh shakhtakh" [Instruction on the insulation of unused mine opening and extraction sections in coal mines]. Moscow, ZAO NTTS PB Publ., 2015, Vol. 05(43), $54 \mathrm{p}$

5. Federalnye normy i pravila v oblasti promyshlennoy bezopasnosti "Pravila bezopasnosti v ugol'nykh shakhtakh" [Safety Rules in the Coal Mines]. Moscow, ZAO NTTS PB Publ., 2015, Vol. 05(40), 196 p.

6. Federal'nye normy i pravila v oblasti promyshlennoy bezopasnosti “Instruktsiya po preduprezhdeniyu endogennykh pozharov i bezopasnomu vedeniyu gornykh rabot na sklonnykh k samovozgoraniyu plastakh uglya" [Instruction on the prevention of the endogenous fires and safe conducting mining operations in coal seams prone to self combustion]. Moscow, ZAO NTTS PB Publ., 2016, Vol. 05(46), 56 p.

\section{КНИЖНАЯ НОВИНКА}

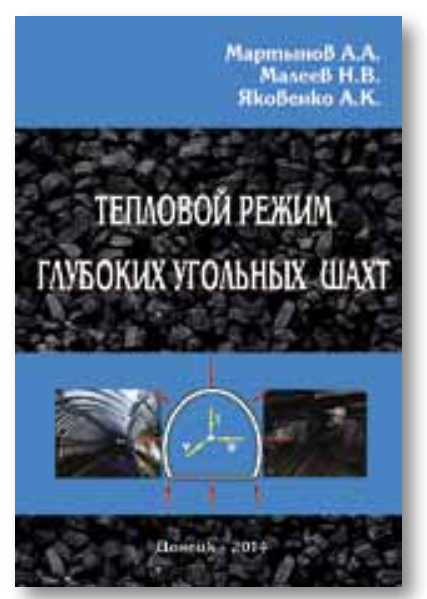

Рекомендовано к изданию

Ученым советом Института

горного дела и геологии

и Ученым советом

Государственного Макеевского

научно-исследовательского института

nо безопасности работ

в горной промышленности.

\section{Тепловой режим глубоких угольных шахт} Мартынов А.А., Малеев Н.В., Яковенко А.К.

Донецк: Издательство «Ноулидж» (Донецкое отделение), 2014. 443 с. ISBN 978-617-579-992-5

В монографии изложены результаты научных исследований теплового режима глубоких шахт. Рассмотрены свойства рудничного воздуха, основные факторы, источники нагрева и процессы, определяющие его тепловое состояние в выработках различного назначения. Освещены санитарно-гигиенические нормативы шахтного климата. Проанализированы особенности формирования шахтного микроклимата при современной технологии подземной добычи угля на больших глубинах. Представлены рациональные по тепловому фактору горнотехнические и технологические решения, обеспечивающие снижение нагрева воздуха в выработках глубоких горизонтов. Рассмотрены физические основы охлаждения шахтного воздуха, связанные с применением искусственного и естественного холода. Изложены данные о выборе технологических схем шахтных систем кондиционирования воздуха, стационарных и передвижных холодильных установок, сведения о способах и технических средствах регулирования шахтного микроклимата.

Приведены основные положения расчета теплового режима горных выработок с использованием специального программного обеспечения. Освещены вопросы рационального проектирования и эксплуатации систем кондиционирования шахтного воздуха.

Монография предназначена для предприятий угольной отрасли, студентов горных специальностей и специалистов, занимающихся вопросами борьбы с высокими температурами воздуха в глубоких шахтах. 


\section{Лучшие шахтеры компании «СУЭК-Кузбасс» награждены автомобилями Volkswagen}

24 лучших горняка компании «СУЭККузбасс» в канун Нового года получили на новогоднем заседании клуба «Добычник» новые машины марки Volkswagen. А всего с начала 2017 года обладателями наградных автомобилей за высокие производственные достижения стали 44 шахтера.

Традиционно лучшие очистные коллективы по итогам года на заседании клуба награждены кубками, дипломами и премиями.

Победителями производственного соревнования стали бригады Юрия Солдатенко и Олега Германа шахты имени С.М. Кирова, Владимира Березовского шахты «Талдинская-Западная- 1 ».

Памятный знак за наибольшее число побед- восемнадцать- в Днях повышенной добычи вручен бригаде Олега Германа шахты имени С.М. Кирова.

Еще одна традиция- награждение на заседании клуба орденом «За особый вклад в развитие СУЭК-Кузбасс». Обладателями высшей награды компании на этом заседании стал бригадир шахты имени А.Д. Рубана Олег Кукушкин.

В рамках клуба состоялось подведение итогов выполнения повышенных обязательств, принятых коллекти-

\section{ЕВРАЗ запустил}

\section{на шахте «Алардинская» лаву \\ с запасами 2,8 млн тонн угля}

На шахте «Алардинская» в декабре 2017 г. введена в эксплуатацию лава 3-38 с запасами около 2,8 млн т коксующегося угля ценной марки КС.

Отработка угля ведется на глубине до 240 м. Для безопасности труда горняков предусмотрена дегазация выработанного пространства вертикальными скважинами, пробуренными с поверхности. В ходе отработки запасов осуществляется непрерывное проветривание лавы с помощью вентилятора главного проветривания.

Добычной забой оснащен высокопроизводительным очистным оборудованием. Компания обновила лавокомплект шахты «Алардинская», закупив современный перегружатель Grot-1100 с дробилкой Scorpion-3000P. Hoвая техника будет способствовать наращиванию объемов производства и обеспечит эффективную безопасную выемку угля из новой лавы.

В новой лаве работает один из самых известных шахтерских коллектив Кузбасса - бригада-миллионер Альберта Ямалиева участка № 1 (начальник участка Валерий Кузнецов). Из нового очистного забоя планируется ежемесячно выдавать на-гора до 240 тыс. т угля до декабря 2018 г.

Шахта «Алардинская» - единственное предприятие Распадской угольной компании, добывающее уголь марки КС. Основными потребителями продукции являются металлургические предприятия ЕВРАЗа. вами на предыдущем заседании, и взятие новых повышенных производственных обязательств на первое полугодие 2018 г.

Также на заседании избран новый президент клуба «Добычник». Большинство голосов набрал бригадир шахты имени С.М. Кирова Юрий Солдатенко.
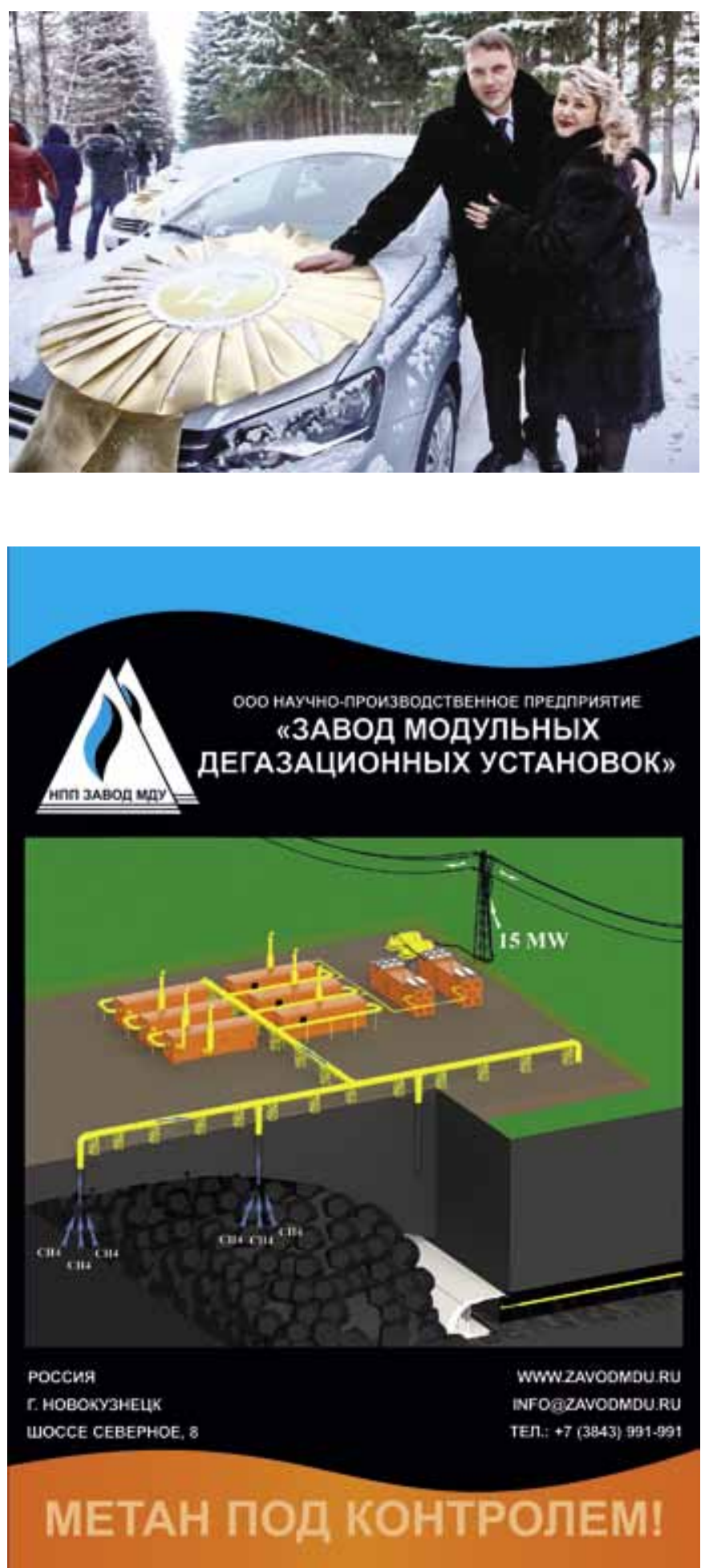

ФЕВРАЛЬ, 2018, “УГОЛЬ” 
Для компании Dassault Systemes - мирового лидера в области решений для 3D-проектирования, создания цифровых 3D-макетов и управления жизненным циклом изделий уже стало традицией собирать журналистов на пресс-ланч в конче года. 19 декабря 2017 г. состоялся пресс-ланч компании, посвященный ключевым проектам в 2017 г., а также важным анонсам в преддверии 2018 г. Мероприятие прошло в инжиниринговом центре прототипирования высокой сложности «Кинетика», где выступил управляющий директор Dassault Systèmes в Poccuи и СНГ Алексей Рыжов.

\section{ЦИФРОВАЯ ЭКОНОМИКА}

Одной из основных и наиболее обсуждаемых тем 2017 г. стала цифровизация экономики. Государство, а вместе с ним и практически все крупнейшие игроки российского рынка объявили о программах цифровой трансформации бизнеса. По данным исследования Mckinsey, в России цифровизация действительно идет высокими темпами - в период с 2011 по 2015 г. совокупный объем цифровой экономики России увеличился на 59\%. Согласно аналитике, основной долей цифровой экономики в России является торговля и сегмент В2С, однако наибольшим потенциалом роста обладают именно такие сферы, как производства и города. В рамках участия в цифровой трансформации российской экономики Алексей Рыжов также рассказал о сотрудничестве Dassault Systèmes c TechNet и Национальной Технологической Инициативой. Центр «Кинетика» также является стратегическим партнером компании в развитии процесса цифровизации в России.

\section{КЛЮЧЕВЫЕ ПРОЕКТЫ И ПАРТНЕРСТВА}

В 2017 г. у Dassault Systèmes был целый ряд важных событий и анонсов, среди которых запуск новых отраслевых решений, сотрудничество с крупнейшими заказчиками, развитие высокотехнологичных проектов, а также важные изменения бизнес-стратегии в России. Ключевыми индустриями для компании остаются транспортная, авиакосмическая, судостроительная, а также отрасль природных ресурсов, в то время как индустрия энергетики и промышленного оборудования развиваются сегодня наиболее активно.

Главными для Dassault Systèmes технологиями являются 3D-симулирование, аддитивное производство, использование ВІМ в капитальном строительстве, а также виртуальная реальность.

- Стратегическое соглашение в сфере инновационных струнных технологий в рамках транспортного проекта SkyWay.

- Объявлен ряд ключевыхпроектов для индустрии природныхресурсов: запускпроекта внедрения решения Quintiqдля оптимизации логистической цепи и бизнес-процессов Новолипецким металлургическим комбинатом, который обладает одной из самых передовых цепей поставок в металлургической отрасли; проекты с компанией «Норникель» на шахте «Скалистая» и месторождении Быстринское.

- Трансформация канала продаж SOLIDWORKS в России. C расширением дистрибьюторской сети SOLIDWORKS теперь обеспечивает поддержку клиентов более чем в 70 городах России и стран СНГ, расширив свою партнерскую сеть до 20 реселлеров.

На международном уровне был заключен целый ряд соглашений с крупнейшими глобальными компаниями. Сотрудничество с Boeing направлено на использование платформы
Dassault Systèmes 3DEXPERIENCE в своих программах коммерческой авиации, а также в космических программах. Другой новый проект - обеспечение управления проектами капитального строительства совместно с Bouygues Construction и Accenture. Компания Doosan Infacore внедрила платформу 3DEXPERIENCE для ускорения реализации своей стратегии трансформации бизнеса с целью стать одним из трех крупнейших машиностроительных предприятий мира. Компания PSA Retail использовала отраслевое решение Dassault Systèmes "Virtual Garage" для создания цифрового формата торгового зала, который привносит высококачественную цифровую визуализацию в процессы продаж, осуществляемые в автосалоне. Сегодня “Experience Store” в Париже предоставляет специальные конфигураторы, в цифровом виде демонстрирующие покупателю автомобили брендов Peugeot, Citroën и DS.

Компания Bouygues Construction ускоряет цифровую трансформацию своей проектной деятельности, сотрудничая c Accenture (NYSE: ACN) и Dassault Systèmes (Euronext Paris: \#13065, DSY.PA), чтобы получить возможность централизованного управления проектами капитального строительства от начала и до конца. Данная инициатива является логическим продолжением активного развития компании в области индустриализации своих операций и улучшения взаимодействия со своими партнерами по цепочке поставок. Компания приступила к реализации этой инициативы после того, как несколько лет назад внедрила методологию информационного моделирования здания (Building Information Modeling, BIM) - концепциюдля интегрированных технологий и процессов, способствующих повышению комплексной эффективности строительной деятельности.

Чтобы оказать поддержку Bouygues Construction в этой новаторской для строительной отрасли инициативе, три компании подписали соглашение по развитию цифровой среды для со вместного управления строительными проектами на базе платформы Dassault Systèmes 3DEXPERIENCE, которая уже используется в других отраслях, в том числе в автомобильной промышленности и в аэрокосмической отрасли.

Компания Dassault Systèmes воплощает принцип 3DEXPERIENCE, обеспечивая компаниям и сотрудникам виртуальную среду для создания устойчивых инноваций. Ведущие решения компании помогают изменить подход к разработке, производству изделий и сервису. Приложения Dassault Systèmes для совместной работы способствуют поиску социальных инноваций, позволяя виртуальному миру улучшать мир реальный. Обеспечивая поддержку свыше 220 тыс. заказчиков, Dassault Systèmes работает более чем в 140 странах мира, с компаниями любого размера и из всех отраслей промышленности. Более подробная информация представлена по адресу www.3ds.com. 
Холдинговая компания «СДС-Уголь» вошла в первую пятерку рейтинга экологической ответственности горнодобывающих и металлургических компаний Всемирного фонда дикой природы (WWF).

По итогам всесторонней оценки компания «СДС-Уголь» заняла 5-е место, продемонстрировав впечатляющую динамику роста, «отыграв» 20 позиций по сравнению с рейтингом предыдущего года.

Рейтинг экологической ответственности горнодобывающих и металлургических компаний составляет Всемирный фонд дикой природы совместно с проектом Программы развития ООН, Глобального экологического фонда и Минприроды России при участии Национального рейтингового агентства уже во второй раз. Компании оцениваются по трем направлениям (экологический менеджмент, воздействие на окружающую среду и прозрачность) всего более чем по 35 критериям. Оценке подвергаются все этапы деятельности - обустройство месторождений, добыча и переработка полезных ископаемых и утилизация отходов. При оценивании прозрачности, в частности, принималась во внимание работа по информированию общественности в спорных экологических ситуациях. Основой для отбора компаний стали материалы доклада Минприроды России «О состоянии и использовании минеральносырьевых ресурсов».

«Цель данного проекта - оценить разные горнодобывающие отрасли с точки зрения экологической ответственности. В пилотный рейтинг были включены 33 компании, в том числе АОХК «СДС-Уголь», - пояснила начальник управления по экологической безопасности и охраны окружающей среды Любовь Тургенева. - По итогам первого рейтинга за 2015 год компания АОХК «СДС-Уголь» вошла лишь в третью десятку, заняв 25-е место. За короткий промежуток времени специалистами компании была проведена маситабная работа в рамках рейтинга по трем направлениям: экологическому менеджменту, уровню воздействия компании на окружающую среду, а также уровню компании по раскрытию информачии о воздействии на окружающую среду в ходе производственной деятельности. В результате, при подведении итогов рейтинга за 2016 год АО ХК «СДС-Уголь» вошло в первую пятерку рейтинга (5-е место), заняв при этом лидирующее положение среди угледобывающих компаний Poccuu».

\section{АО «Дальтрансуголь» - эколидер Хабаровского края}

В правительстве Хабаровского края состоялось торжественное мероприятие, в рамках которого подвели итоги Года экологии и наградили победителей традиционного краевого конкурса «Эколидер». АО «Дальтрансуголь» присвоено звание «Эколидер 2017» / степени в категории «Крупное предприятие», а также оно награждено дипломом конкурса.

В 2017 г. краевой экологический конкурс «Эколидер» проводился Министерством природных ресурсов Хабаровского края уже в 11-й раз. Заявки на конкурс поступили из 14 муниципальных образований Хабаровского края. Общее количество желающих принять участие - 91 конкурсант - стало максимальным за все годы существования конкурса. Проекты экологической направленности и свои достижения в области охраны окружающей среды представили разнообразные организации края, в том числе и ветеранские, предприятия, индивидуальные предприниматели, юридические лица, отдельные граждане, учреждения города и администрации городских округов и районов.

Оценивались работы по множеству категорий: «Крупное предприятие», «Предприятие среднего и малого бизнеса», «Муниципальное образование», «Образовательное учреждение», «Энтузиаст», «Профи», «Учреждение, организация», «Сохраним амурского тигра», «Средство массовой информации».

Напомним, что в 2017 г. АО «Дальтрансуголь» провело серию мероприятий по обеспечению экологической безопасности в Ванинском муниципальном районе, на которые затрачено более 164 млн руб.

В 2016 г. Дальтрансуголь занял II-е призовое место по результатам ежегодного краевого экологического конкурса «Эколидер» в категории «Крупное предприятие». 


\section{Предприятия СУЭК в Красноярском крае успешно начали работу в 2018 году}

Предприятия Сибирской угольной энергетической компании в Красноярском крае стабильно отработали новогодние праздничные дни, обеспечив потребителей - крупнейшие станции, коммунально-бытовые объекты и частный сектор - необходимым объемом твердого топлива. Всего с начала 2018 года разрезы «Бородинский имени М.И. Щадова»,

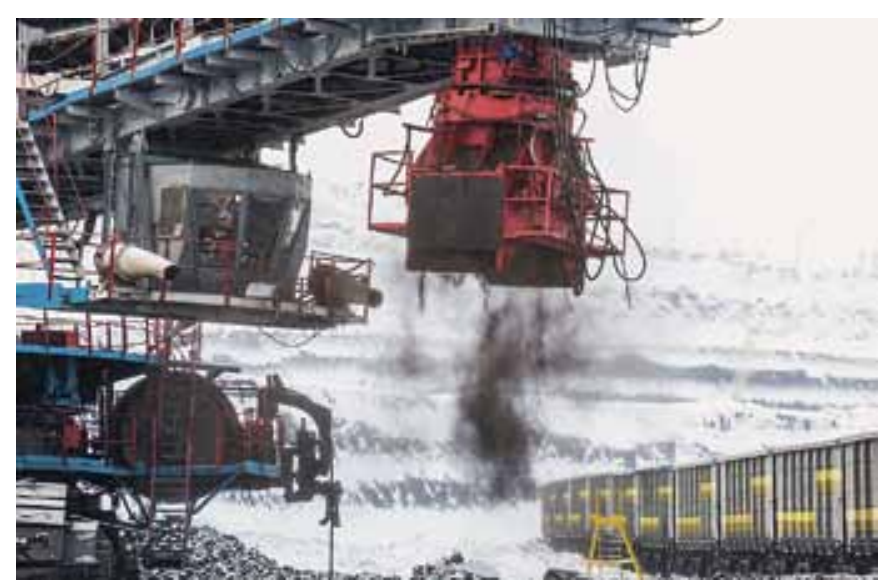

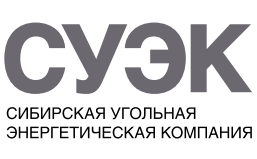

«Назаровский» и «Березовский» отгрузили потребителям около 800 тыс. т угля, что на $6 \%$ выше производственного плана. Отгрузка не прекращалась даже в ночь с 31 декабря на 1 января.

«Всравнении спредыдущимигодами началоянваря выдалось достаточно теплым, тем не менее в отдельные дни работа была осложнена туманом и плохой видимостью. Несмотря на это, праздники мы отработали стабильно, производительно, без серьезных поломок, прежде всего благодаря профессионализму наших горняков. Важный вклад в бесперебойные поставки топлива внесли и наши сервисные предприятия - ремонтные и транспортное железнодорожное подразделения», - рассказал генеральный директор АО «СУЭК-КрасноярсК» Андрей Федоров, подчеркнув, что в случае резкого понижения температуры воздуха угледобывающие предприятия полностью готовы к повышенным нагрузкам с целью сохранения энергобезопасности в регионе.

Добавим, по итогам 2017 года предприятия СУЭК в Красноярском крае добыли около 28 млн т угля. В наступившем году перед ними стоит задача взять планку в 30 млн т.

\section{АО «СУЭК-Красноярск» инвестировало почти 30 млн руб.} в развитие интеллектуального потенциала

Почти 30 млн руб. выплатило АО «СУЭККрасноярск» своим сотрудникам за рационализаторские идеи и предложения, в том числе в 2017 г. объем премирования составил 3 млн руб.

В угольной компании подвели итоги работы постоянно действующей с 2010 г. комиссии по раци онализаторской деятельности. За это время благодаря инициативе горняков реализовано более 280 мероприятий по повышению эффективности и безопасности производства. Общий экономический эффект от их внедрения превысил 300 млн руб.

Как подчеркнул председатель комиссии, финансовый директор АО «СУЭК-Красноярск» Андрей Великосельский, количество рационализаторских проектов, которые предлагают сотрудники, чтобы оптимизировать свой труд, растет ежегодно. «Если в первые годы работы комиссии мы рассматривали около 20 проектов, то в 2017-м и предшествующие ему несколько лет объем идей и предложений стабильно достигает 60. Росту деловой активности персонала способствует как четко отстроенный механизм финансового поощрения сотрудников, так и друге способы мотивации, например возможность дополнительного обучения и повышения квалификачии для инициативных сотрудников", - пояснил он.

Среди крупнейших проектов, реализованных в 2017 г., Андрей Великосельский выделил такие, как изменение технологии вскрышных работ на Назаровском разрезе - эффект от преобразований превысил 4 млн руб., модернизация подачи связующего в дозирующий бункер на участке брикетного производства Березовского разреза, замена однониточных импульсных рельсовых цепей переменного тока на фазочувствительные с реле в Бородинском погрузочнотранспортном управлении и другие.

В то же время, по его словам, сегодня значительно изменился подход к оценке проектов - кроме новизны, актуальности, экономического эффекта особое внимание уделяется безопасности. «Все предлагаемые сотрудниками предложения по внесению изменений в технологию, работу оборудования должны пройти обязательную сертификацию», - подчеркнул председатель комиссии по рационализаторской деятельности.

Кстати, наиболее интересные и жизнеспособные проекты АО «СУЭК-Красноярск» публикует в специальном рационализаторском вестнике «От идеи до рекорда». Издание распространяется не только на предприятиях в Красноярском крае, но и направляется в Москву и другие региональные подразделения СУЭК, что открывает перед проектами перспективу дальнейшего тиражирования, а перед предприятиями - возможности для дальнейшего повышения эффективности за счет мобилизации внутренних ресурсов. 


\section{На красноярских предприятиях СУЭК завершается}

\section{реализация проекта, направленного на снижение риска \\ общего и глазного травматизма,}

улучшение качества жизни сотрудников,

имеюцих проблемы со зрением

Проект стал частью комплексной корпоративной программы «Здоровье», включающей такие подпрограммы, как «Здоровое питание», «Антитабак» (помощь сотрудникам в отказе от курения), «Здоровый образ жизни» (создание условий и привлечение к занятиям физкультурой и спортом, участие в спортивных соревнованиях).

В течение сентября-декабря 2017 г. на предприятиях СУЭК в Красноярском крае исследование органов зрения прошли около 1,5 тыс. человек, что составляет более трети трудового коллектива. Партнером по реализации проекта стал центр коррекции зрения «Окулюс»: врачиофтальмологи провели осмотры как в краевом центре, так и с выездом на предприятия в Бородино, Назарово и Шарыпово. Все необходимое оборудование производства Японии, Кореи, США медицинский десант также привез с собой. Важным направлением проекта стало обеспечение сотрудников так называемыми корригирующими очками для коррекции нарушений зрения.

«На собственном опыте знаю, насколько важно видеть мирв подробностях, посколькутоженошуочки. Есливидишь не четко, можно и ступеньку не заметить, и не в свой автобус войти. Еще более важна предосторожность на произ- водстве. Междутем распространенность аметропий в обществе в челом очень высока, она занимает примерно шестое место среди различных заболеваний. СУЭК социальноответственнаякомпания, идля снижения рисков натранспорте, производстве и в быту для сотрудников с недостаточным зрением управлением медицины труда была инициирована акция по обеспечению корригирующими очками. Ни одного нарекания или хотя бы просто нейтрального отзыва по поводу работы офтальмологовя неуслышала, только положительные. Так и говорят: врачи - молодиы! Спасибо Компании за такую акцию!» - отметила заместитель руководителя службы промышленной безопасности, экологии, охраны и медицины труда АО «СУЭК-Красноярск» Валентина Хусаинова.

Опыт подобных осмотров красноярцы также распространили на коллег из Иркутска и шахтерского поселка Саган-Нур Республики Бурятия. Причем в Саган-Нуре, удаленном от республиканского центра почти на 200 км, красноярские медики не только организовали диагностику сотрудникам и ветеранам предприятий СУЭК, в том числе страдающим сложными офтальмологическими заболеваниями, но и провели мастер-класс для врача-офтальмолога центральной районной больницы.

Пресс-служба АО ХК «СДС-Уголь» информирует

\section{Проектный институт «СИГД» подтвердил соответствие системы менеджмента качества ГОСТ Р ИСО 9001 - 2015}

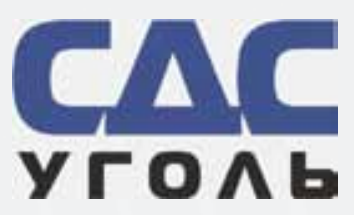

единицы института. В результате проверки установлено, что система менеджмента качества ООО «СИГД» функционирует результативно и поддерживается в соответствии с требованиями стандарта ГОСТ Р ИСО 9001-2015 (ISO 9001:2015).

«Мероприятия поулучшению системы менеджментакачества, которые были внедрены в институте, позволили повысить результативность процессов проектирования, выполнять проекты на высоком техническом уровне в установленные сроки и в соответствии с заключенными договорами, - отмечает директор ООО «СИГД» Татьяна Корчагина. - Система менеджмента качества проектных работ, соответствующая требованиям ISO 9001:2015, имеет определяющее значение при стратегическом планировании деятельности института».
В процессе проведения инспекционного контроля комиссией проверены все подразделения и структурные 


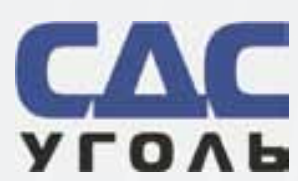

Пресс-служба АО ХК «СДС-Уголь» информирует

\section{Три экскаваторные бригады АО ХК «СДС-Уголь» стали рекордсменами по итогам января}

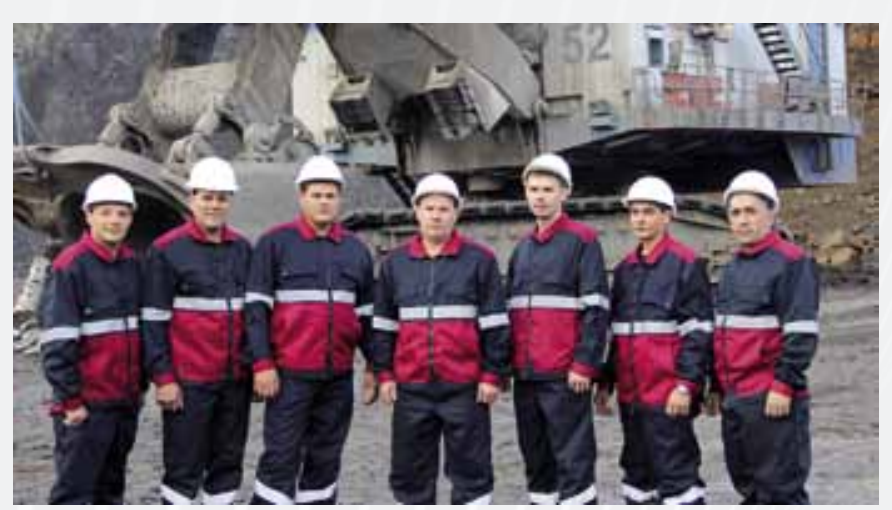

Экипаж Руслана Федякина, экскаватор Р\&H 2800 № 52

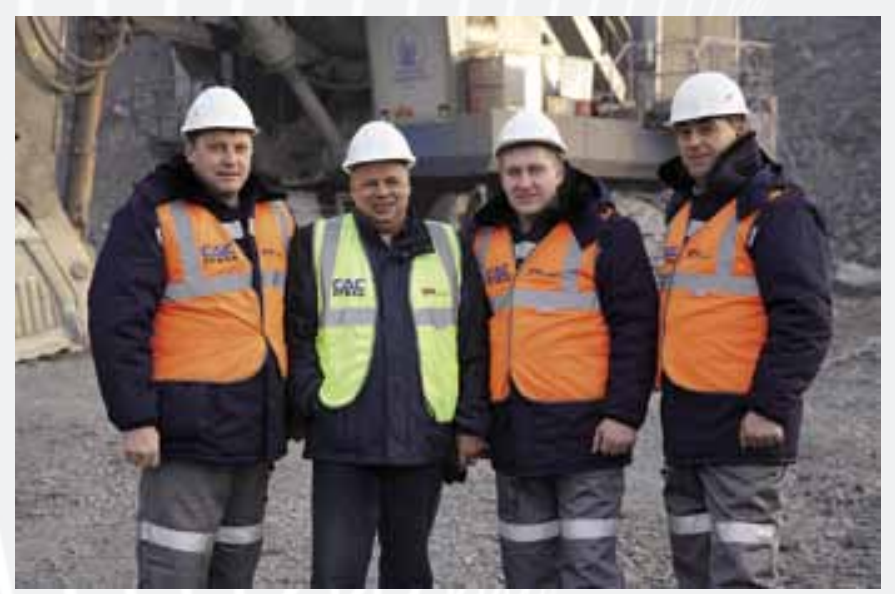

Бригада Вячеслава Санникова, экскаватор Hitachi EX3600

По итогам января 2018 г. предприятия АО ХК «СДСУголь» отработали в плановом режиме. Несмотря на экстремальные природно-климатические условия и праздники, большинство экскаваторных бригад предприятий открытой добычи угля отработали спревышением плановых показателей.

Особо отличилась бригада 33-кубового экскаватора Р\&H 2800 № 52 под руководством Руслана Федякина разреза «Черниговец». За месяц горняки отгрузили более 1 млн куб. м вскрышной породы, что на 54 тыс. куб. м превышает объем месячного задания.

Самый высокий суточный показатель по отгрузке горной массы у бригады машинистов экскаватора Р\&H 2800 № 50 Анатолия Мухаметсалимова разреза «Черниговец». Так, за 28 января, при плане 34,1 тыс. куб. м, ими отгружено 57,8 тыс. куб. м.

Среди экипажей экскаваторов марки Hitachi EX3600 (вместимость ковша 21 куб. м) наилучший результат у бригады под руководством Вячеслава Санникова разреза «Восточный» (АО «Салек»). При плане 550 куб. м отгружено 690 куб. м горной массы, что на 25\% превышает месячную норму.

«Значительныхрезультатов экскаваторные бригадыдостигли благодаря грамотной организации производственного прочесса. Особое внимание на предпиятиях было уделено своевременным планово-предупредительным ремонтам экскаваторного парка, что дало возможность отработать с высокой производительностью», - пояснил заместитель генерального директора по производству АО ХК «СДС-Уголь» Игорь Балашов.

\section{Проходческие бригады холдинга «СДС-Уголь» прошли более 1800 м горных выработок за январь 2018 г.}

В бригадной работе по горной проходке за январь 2018 г. отмечены передовики шахт угольного холдинга «СДС-Уголь» (входит в состав АО ХК «Сибирский Деловой Союз) - «Листвяжной» и «Южной».

На шахте «Листвяжная» в январе 2018 г. перевыполнены планы проходки горных выработок бригадой Сергея Филимонова более чем на 52\% сверх норматива ГПКС (350 м).

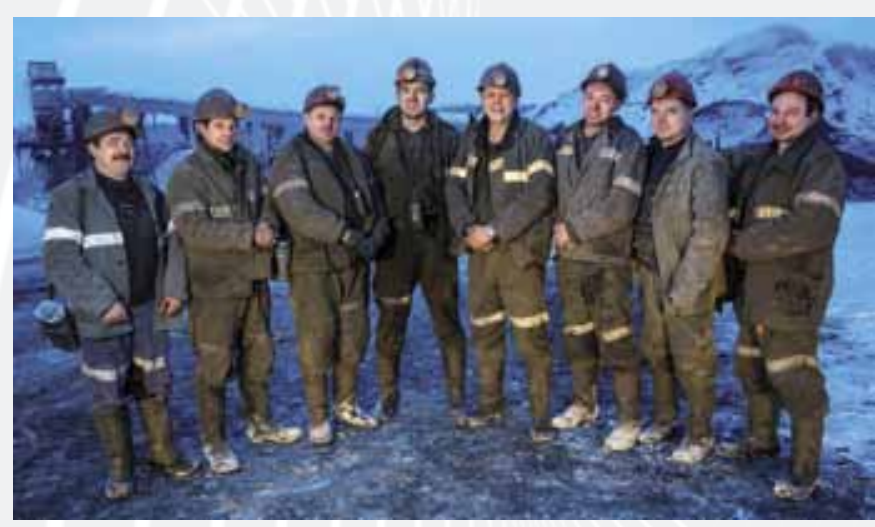

Проходчики шахты «Южная»
Проходческие коллективы шахты «Южная» (филиал АО «Черниговец») по итогам января 2018 г. прошли 990 м горных выработок, улучшив результат января 2017-го (335 м) на $195 \%$.

Для подготовки очистного фронта проходческие бригады шахты «Южная» за январь перевыполнили план горных выработок на $14 \%$. Лучший результат у бригады под руководством Алексея Ширшина. При прохождении южной монтажной печи за месяц проходчики прошли 140 м горных выработок, превысив плановый показатель на 155\% (план - 50 м).

Бригада Андрея Пачея перевыполнила плановое задание месяца на 13\%, пройдя 136 м горных выработок сбойки и вентиляционного штрека 10Л. Также с превышением плана отработали проходческие бригады под руководством Андрея Блинова и Сергея Варфоломеева.

В феврале 2018 г. коллектив шахты «Южная» взял на себя плановые обязательства увеличить показатель по проходке горных выработок на $32 \%$ от факта января (1310 м). До конца года проходчики шахты «Южная» планируют пройти более 15000 м горных выработок, выдать на-гора более 2,7 млн т угля. 


\section{К вопросу переработки}

\section{угольных шламов}

DOI: http://dx.doi.org/10.18796/0041-5790-2018-2-77-80

Представлена технологическая установка комплексной переработки угольных шламов из наружных отстойников обогатительной фабрики «Черниговская» разреза «Черниговец» (АО ХК «СДС-Уголь»). Использование данной установки позволяет осуществить перевод угля из разряда потерь в товарную продукцию высокого качества, соответствующую требованиям потребителей. В настоящей статье выполнено экономическое обоснование переработки угольных шламов на предлагаемой технологической установке. Ключевые слова: угольный шлам, обогащение, безотходные технологии.

\section{ВВЕДЕНИЕ}

Энергетическая стратегия Российской Федерации на период до 2030 г. предусматривает увеличение доли угля в топливном балансе страны за счет новыхтехнических решений добычи и переработки угля, обеспечивающих рациональное природопользование и охрану природной среды [1].

При переработке рядового угля на обогатительной фабрике «Черниговская» (АО «Черниговец»), построенной по проекту института «Кузбассгипрошахт» и сданной в эксплуатацию в 1974 г., образуется угольный шлам, который складируется в наружные шламоотстойники.

В настоящее время в наружных отстойниках фабрики скопилось более 1 млн т необогащенного угольного шлама. Общая площадь загрязнения наружными отстойниками составляет около 19 га непригодной для рекультивации территории $[2,3,4,5]$.

\section{УСТАНОВКА КОМПЛЕКСНОЙ ПЕРЕРАБОТКИ УГОЛЬНЫХ ШЛАМОВ ИЗ НАРУЖНЫХ ОТСТОЙНИКОВ ОФ «ЧЕРНИГОВСКАЯ»}

Специалистами ООО «Сибирский Институт Горного Дела», являющегося одним из структурных подразделений АО ХК «СДС-Уголь», разработана установка по переработке угольных шламов из наружных отстойников обогатительной фабрики «Черниговская» часовой производительностью 50 т [6, 7, 8, 9, 10, 11].

В результате обогащения угольных шламов на данной установке получаем товарную продукцию и отходы обогащения в обезвоженном виде. В дальнейшем отходы направляются на породный отвал. Товарная продукция реализуется потребителям для энергетических нужд.

Общий вид обогатительной установки представлен на puc. 1.

По результатам отбора проб установлено средневзвешенное качество находящегося в шламоотстойниках угля: зольность - 26,6\%, высшая теплота сгорания на сухое беззольное состояние - 8167 ккал/кг, то есть уголь, содержа-

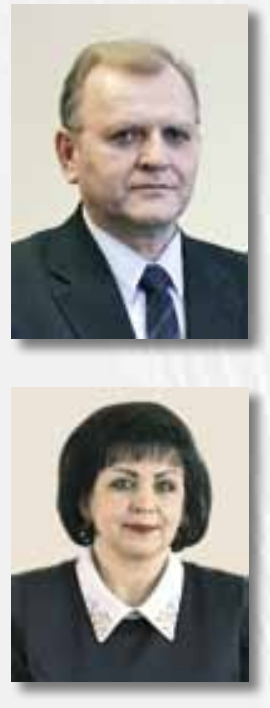

ЕФИМОВ Виктор Иванович

Доктор техн. наук, заместитель директора по перспективному развитию Филиала АО ХК «СДС-Уголь» в г. Москве, nрофесссор НИТУ «МИСиС», 119034, г. Москва, Россия, e-mail:v.efimov@sds-ugol.ru

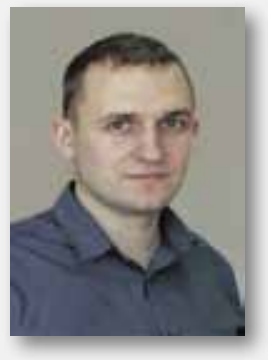

КОРЧАГИНА Татьяна Викторовна

Канд. техн. наук, Директор 000 «Сибирский Институт Горного Дела», 653066, г. Кемерово, Россия, e-mail: t.korchagina@sds-ugol.ru

\section{АНТОНОВ Алексей Игоревич Начальник отдела технологии обогащения ООО «Сибирский Институт Горного Дела», 653066, г. Кемерово, Россия, e-mail:a.antonov@pk-ugol.ru}

щийся в шламе, сохранил свои потребительские свойства. Технологическая схема переработки угольных шламов на установке представлена на рис. 2.

Извлечение шлама из шламоотстойника осуществляется погружным насосом с агитатором. Агитатор создает сильную вертикальную тягу, которая заставляет осевшие твердые частицы перейти во взвешенное состояние. Извлеченный шлам транспортируется насосом на высокочастотный грохот для предварительной (мокрой) классификации по классу крупности +2 мм и отделения посторонних предметов. Подрешетный продукт самотеком транспортируется в зумпф. Надрешетный продукт транспортируется ленточным конвейером в штабель отходов.

Процесс классификации и обезвоживания на высокочастотном грохоте происходит за счет высокочастотных колебаний грохота. Подрешетный продукт грохота насосом подается для классификации по классу 0,2 мм на блок гидроциклонов, где осуществляется разделение на пески (класс +0,2 мм) и слив (класс -0,2 мм). Угольный шлам подается насосом в корпус гидроциклонов по касательной, где в результате вращения создается центробежное поле и происходит классификация по крупности. Крупные 


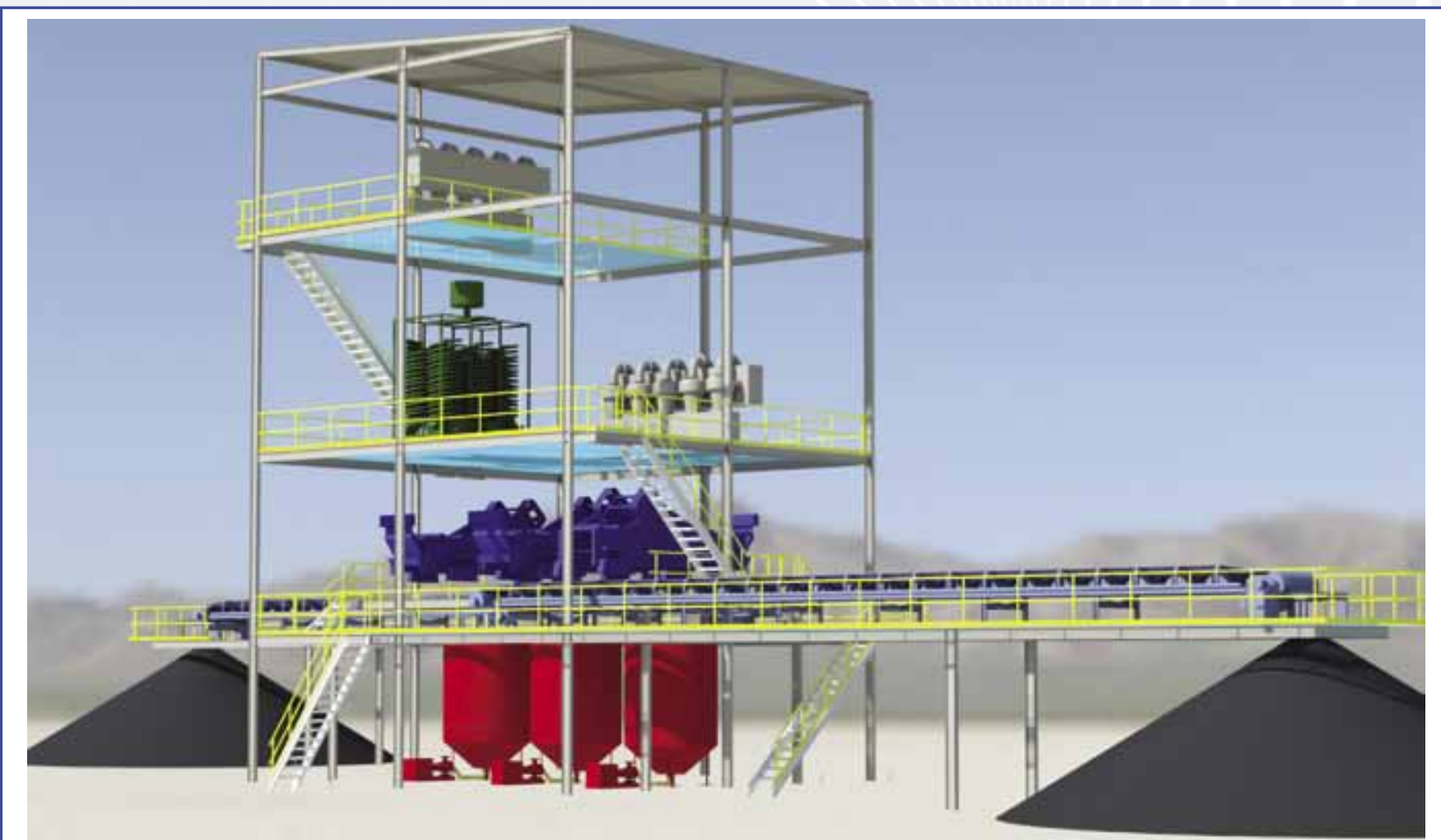

Рис. 1. Общий вид обогатительной установки

Fig. 1. Concentration unit overview

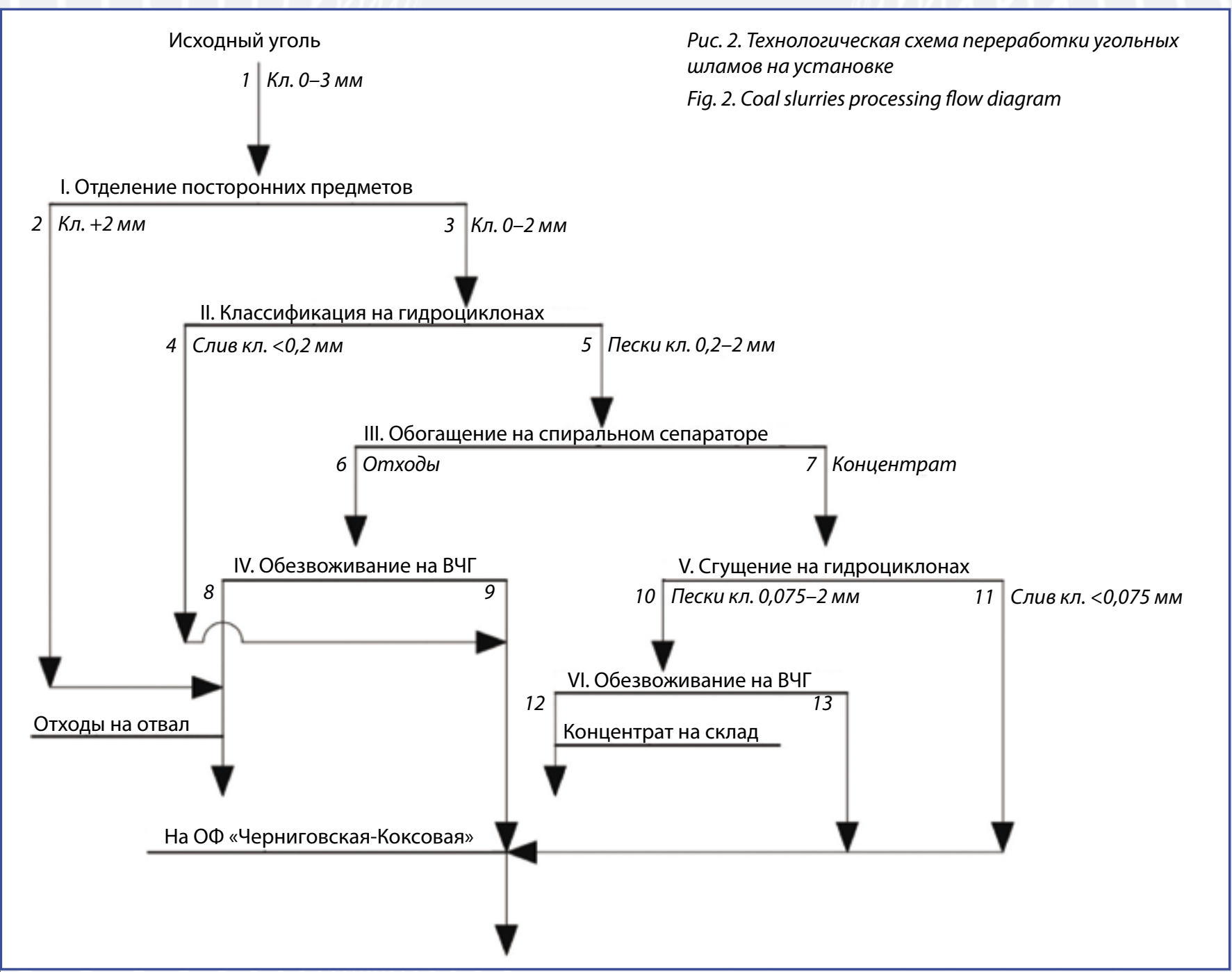




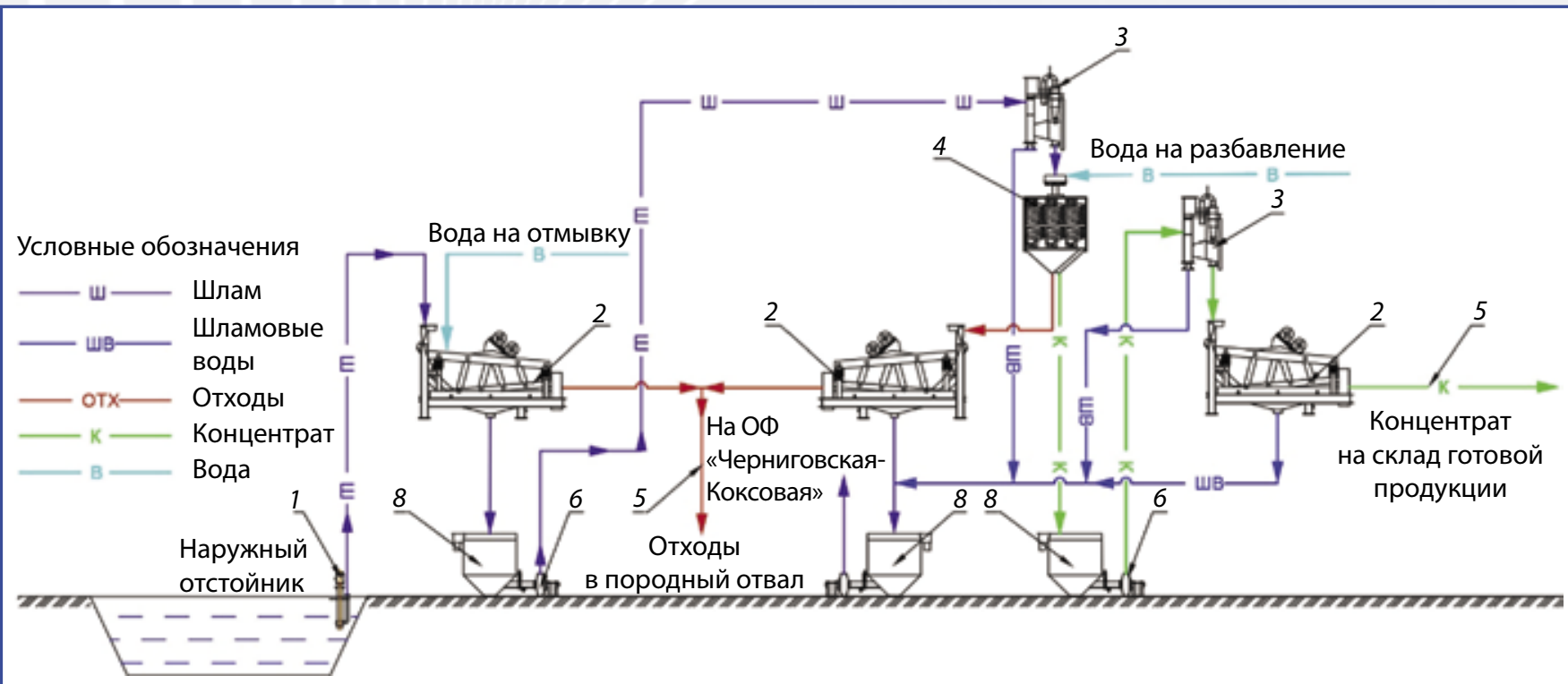

Pис. 3. Схема цепи аппаратов установки по переработке угольных шламов: 1 - насос погружной (1 шт.); 2 - высокочастотный грохот (3 шт.); 3 - блок гидроциклонов (2 шт.); 4 - блок спиральных сепараторов (1 шт.); 5 - ленточный конвейер (2 шт.); 6, 7 - насос шламовый (3 uт.); 8 - зумпф (3 шт.)

Fig. 3. Coal slurries units process chain: 1 - submersible pump (1 pc.); 2 - high frequency screen (3 pcs.); 3 - hydrocyclone module (2 pcs.); 4 spiral separator module (1 pc.); 5 - belt conveyor (2 pcs.); 6, 7 - slurry pump (3 pcs.); 8 - sump (3 pcs.)

частицы удаляются через песковую насадку. Более мелкие частицы удаляются через верхний патрубок в виде слива. Слив (класс -0,2 мм) самотеком транспортируется в зумпф и далее насосом подается для обогащения на ОФ «Черниговская-Коксовая». Пески (класс +0,2 мм) самотеком подаются в приемный стакан спиральных сепараторов для обогащения.

Обогащение на спиральном сепараторе осуществляется за счет действия центробежных сил, а также за счет сил трения. Отходы спиральных сепараторов обезвоживаются на высокочастотном грохоте. Обезвоженные отходы транспортируются ленточным конвейером в штабель отходов. Подрешетный продукт объединяется со сливом гидроциклонов классификации и транспортируется насосом на ОФ «Черниговская-Коксовая» для дальнейшего обогащения.

Концентрат спиральных сепараторов самотеком транспортируется в зумп ф питания гидроциклонов сгущения и далее насосом подается для сгущения на гидроциклонах. На гидроциклонах сгущения выделяются пески (класс $+0,075$ мм) и слив (класс -0,075 мм).

Пески гидроциклонов сгущения обезвоживаются на высокочастотном грохоте, где обезвоженный продукт является товарной продукцией, а подрешетный продукт совместно со сливом гидроциклонов транспортируется насосом на ОФ «Черниговская-Коксовая» для дальнейшего обогащения.

На обогатительной фабрике «Черниговская-Коксовая» шлам обогащается на флотационных машинах с получением угольного концентрата зольностью 9,5\% и дополнительным выходом товарной продукции 24,8\%. Выход концентрата, получаемый на установке по переработке угольных шламов, составляет 40,6\% с зольностью 10,9\%.

Суммарный выход товарной продукции (установка и ОФ «Черниговская-Коксовая») составляет 65,4\%, или 98139,4 т в год с зольностью $10,4 \%$.
Схема цепи аппаратов установки по переработке угольных шламов представлена на рис. 3.

Расчеты качественно-количественной и водношламовой схем выполнены с учетом рекомендаций и требований нормативных документов, а также на основании гранулометрического и фракционного составов, представленных службой ОТК ОФ «Черниговская».

Экономическая оценка эффективности данной работы:

- товарная продукция может быть реализована по цене 2092 руб./т как энергетический уголь;

- себестоимость товарной продукции составляет 919 руб./т;

- чистый дисконтированный доход - 341 млн руб.;

- вложенные денежные ресурсы окупятся через 1,6 года;

- индекс доходности - 2,8;

- бюджетная эффективность - 109 млн руб.

\section{ЗАКЛЮЧЕНИЕ}

Таким образом, при рекомендуемой в условиях рыночной экономики внутренней норме доходности 10\% строительство установки по переработке шламов является экономически целесообразным и эффективным. Внутренняя норма доходности составит 14,1\%.

Основные преимущества данной установки:

- высокая экономическая эффективность;

- невысокие капитальные затраты (срок окупаемости установки составит 1,6 года, доходность за первую пятилетку - 341 млн руб.);

- неприхотливость в обслуживании (установка имеет минимум вращающихся частей и механизмов, все технологические процессы по максимуму автоматизированы);

- транспортабельность (конструкция установки проектируется разборного типа, после отработки одного шламохранилища предусмотрена возможность переноса всего оборудования и несущих конструкций к другим хранилищам); 
- экологическая безопасность (территория осушенных шламоотстойников в дальнейшем пригодна для рекультивации).

Перевод угольных шламов в технологически приемлемое топливо позволит не только улучшить экологическую обстановку в угледобывающих регионах, но и добиться существенного экономического эффекта.

\section{Список литературы}

1. Энергетическая стратегия России на период до 2030 г: утв. распоряжением Правительства РФ от 13.11.2009. № 1715p. М., 2010. 138 c.

2. Ефимов В.И., Рыбак Л.В. Производство и окружающая среда. М., 2012. 301 с.

3. Ефимов В.И., Никулин И.Б., Рыбак В.Л. Использование отходов углеобогащения и оптимизация ресурсов по экологическому фактору // Известия Тульского государственного университета. Науки о Земле. 2014. № 1. С. 85-95.

4. Ефимов В.И. Управление качеством: учебное пособие. М., 2014. 382 C.

5. Ефимов В.И., Сидоров Р.В., Корчагина Т.В. К вопросу образования отходов производства от предприятий угольной отрасли Кузбасса // Горный информационноаналитический бюллетень. 2017. № 1. С. 85-96.

6. Авдохин В.М. Обогащение углей: учебник для вузов: в 2 т. Т. 2 Технологии. 2-е изд., перераб. и доп. М.: Горная книга. 2012. 475 с.

7. Методические рекомендации по оценке эффективности инвестиционных проектов (вторая редакция) М.: Экономика, 2000. 421 с.

8. Оборотное водоснабжение углеобогатительных фабрик / И.С. Благов, М.А. Борц, Б.И. Вахрамеев и др. М.: Недра, 1980. 214 с.

9. Папин А.В., Неведров А.В., Сечин А.И. Комплексная переработка низкосортных углей и отходов углеобогащения // Ползуновский вестник. 2014. № 3. С. 220-223.

10. Полулях А.Д., Пилов П.И., Егурнов А.Е. Практикум по расчетам качественно-количественных и водно-шламовых схем углеобогатительных фабрик. Днепропетровск: ДонГУ, 2007. 504 с.

11. Федотов К.В., Никольская Н.И. Проектирование обогатительных фабрик: учебник, 2-е изд., перераб. и доп. М.: Горная книга, 2014. 536 с.

COAL PREPARATION

UDC 622.7:662.654.1 ๑ V.I. Efimov, T.V. Korchagina, A.I. Antonov, 2018

ISSN 0041-5790 (Print) • ISSN 2412-8333 (Online) • Ugol' - Russian Coal Journal, 2018, № 2, pp. 77-80

Title

ON COAL SLURRY PROCESSING

DOI: http://dx.doi.org/10.18796/0041-5790-2018-2-77-80

\section{Authors}

Efimov V.I. ${ }^{1,2}$, Korchagina T.V. ${ }^{3}$, Antonov A.I. ${ }^{3}$

1 "SBU-Coal" Holding Company, JSC, Moscow Branch, Moscow, 119034, Russian Federation

${ }^{2}$ National University of Science and Technology "MISIS" (NUST "MISIS"), Moscow, 119049, Russian Federation

3 "Mining Engineering Institute of Siberia", LLC, Kemerovo, 653066, Russian Federation

\section{Authors' Information}

Efimov V.I., Doctor of Engineering Sciences, Professor, Deputy Director for Future Development, e-mail: v.efimov@sds-ugol.ru Korchagina T.V., PhD (Engineering), Director, e-mail:t.korchagina@sds-ugol.ru

Antonov A.I., Head of Department of Technology of Preparation, e-mail: a.antonov@pk-ugol.ru

\section{Abstract}

Presented is the process unit for integrated processing of coal slurries from the external sedimentation tanks of the Chernigivka concentrator is shown in the Chernigovets section (HC SBU-Coal). The use of this unit enables coal transfer from the category of losses into high-quality commodity products, meeting consumers specifications. This article provides an economic feasibility study of coal slurries processing using proposed process unit. Figures:

Fig. 2. Coal slurries processing flow diagram

Fig. 3. Coal slurries units process chain: 1 -submersible pump (1 pc.); 2 - high frequency screen (3 pcs.); 3 - hydrocyclone module (2 pcs.); 4-spiral separatormodule (1 pc.); 5 - belt conveyor (2 pcs.); 6, 7 -slurry pump (3 pcs.); 8 -sump (3 pcs.)

\section{Keywords}

Coal slurry, Concentration, Non-waste technologies

\section{References}

1. Energeticheskaya strategiya Rossii na period do 2030 goda: Utverzhdeno rasporyazheniem Pravitelstva RF ot 13.11.2009 N $1715 \mathrm{r}$. [Energy strategy of Russia until 2030]. Endorsed by the resolution of RF Government No. 1715 r, dated 13.11.2009. Moscow, 2010, 138 p.

2. Efimov V.I. \& Rybak L.V. Proizvodstvo iokruzhayushchaya sreda [Production and environment]. Moscow, 2012, $301 \mathrm{p}$.

3. Efimov V.I., Nikulin I.B. \& Rybak L.V. Ispolzovanie othodov ugleobogashcheniya i optimizatsiya resursov po ekologicheskomu faktoru [Coal ben- eficiation wastes utilization and resources optimization with account for environmental factor]. Izvestiya Tul'skogo gosudarstvennogo universiteta. Nauki o Zemle - Newsletter of the Tula State University. Earth Sciences, 2014, No. 1, pp. 85-95.

4. Efimov V.I. Upravlenie kachestvom: Uchebnoe posobie [Quality management: Educational aid]. Moscow, 2014, 382 p.

5. Efimov V.I., Sidorov R.V. \& Korchagina T.V. K voprosu obrazovaniya otkhodov proizvodstva ot predpriyatiy ugol'noy otrasli Kuzbassa [On wastes generation by Kuzbass coal enterprises]. Gornyy Informatsionno-Analiticheskiy Byulleten' Mining Information and Analytical Bulletin, 2017, No. 1, pp. 85-96.

6. Avdokhin V.M. Obogashchenie ugley: Uchebnik dlya vuzov v 2 tomah. T.2 Tekhnologii 2-e izd pererab. i dop. [Coal beneficiation: Textbook for high schools, in 2 volumes. Vol. 2 Technologies, 2-nd edition, updated and revised]. Moscow, Gornaya Kinga Publ., 2012, 475 p.

7. Metodicheskie rekomendatsii po otsenke effektivnosti investitsionnyh proektov vtoraya redaktsiya [Methodical recommendations for investment projects efficiency evaluation (second revision)]. Moscow, Ekonomika Publ., 2000, 421 p. 8. Blagov I.S., Borts M.A., Vakhrameyev B.I. et al. Oborotnoe vodosnabzhenie ugleobogatitelnyh fabrik [Coal beneficiation factories recycle water supply]. Moscow, Nedra Publ., 1980, 214 p.

9. Papin A.V., Nevedrov A.V., Sechin A.I. Kompleksnaya pererabotka nizkosortnyh ugley i othodov ugleobogashcheniya [Low grade coal and beneficiation wastes integrated processing]. Polzunovskiy vestnik - Polsunovsky Newsletter, 2014, No. 3, pp. 220-223.

10. Polulyakh A.D., Pilov P.I. \& Egurnov A.E. Praktikum po raschetam kachestvenno-kolichestvennyh i vodno-shlamovyh skhem ugleobogatitelnyh fabrik [Workshop for coal beneficiation factories qualitative-quantitative and water-slime flow diagrams computation]. Dnepropetrovsk, DonGU Publ., 2007, 504 p.

11. Fedotov K.V., Nikolskaya N.I. Proektirovanie obogatitelnyh fabric: Uchebnik, 2-e izd pererab i dop. [Beneficiation factories design: Textbook, 2-nd edition, revised and updated]. Moscow, Gornaya Kniga Publ., 2014, 536 p. 


\section{Кластерная организация месторождения как основа планирования оптимальной}

\section{плотности сети углеразведочных скважин}

DOI: http://dx.doi.org/10.18796/0041-5790-2018-2-81-87

Актуальность исследования связана с вопросами обеспечения эффективного управления качеством угольной продукции при эксплуатации месторождения в направлении обеспечения действенного планирования опережающей эксплуатационной разведки как инструмента, позволяющего получить максимально полную информацию о качественных показателях полезного ископаемого. При этом первично сам процесс планирования опережающей эксплуатационной разведки непосредственно ориентирован на: обработку имеющейся информации по месторождению; выделение горно-геологических факторов, влияющих на изменчивость и неоднородность показателей качества угля в массиве горных пород; учет порядка отработки месторождения полезного ископаемого. Учитывая данное обстоятельство, а также задачи, стоящие перед опережающей эксплуатационной разведкой, вопрос о размещении разведочных скважин по площади месторождения для обеспечения максимальной информативности процесса продвижения фронта горных работ зависит от модели месторождения, обеспечивающей представления угольного месторождения как объекта изучения. Таким образом, модели месторождения, которые будут приняты на стадии эксплуатации месторождения горным предприятием, в дальнейшем будут оказывать значительное влияние на эффективность управления качеством угольной продукции и возможность варьирования решениями при текущем планировании и контроле за ведением горных работ на месторождении. Объект исследования - углепородный массив Эльгинского каменноугольного месторождения Южно-Якутского бассейна в пределах угольных пластов, принятых к открытой разработке. Результаты исследования. Разработан подход к кластерной организации угольных месторождений. Даны определения относительно угольныхместорождений по следующим понятиям: кластерная организация угольного месторождения; кластерная зона угольного месторождения; кластерная зона геологоразведочного профиля; зона влияния геологоразведочного профиля; базовый и кластерный профиль. На основе кластерной организации угольного месторождения заданы основные принципы для планирования оптимальной плотности разведочных скважин опережающей эксплуатационной разведки. В качестве примера представлен переход к кластерной организации участка 2 Эльгинского каменноугольного месторождения.

Ключевые слова: Эльгинское каменноугльное месторождение, кластерная организация угольного месторождения, кластерная зона угольного месторождения, кластерная зона геологоразведочного профиля, зона влияния геологоразведочного профиля, базовый профиль и кластерный профиль, опережающая эксплуатационная разведка.

\section{ВВЕДЕНИЕ}

В современных экономических условиях вопросы управления качеством продукции горного предприятия являются весьма актуальными, так как именно они являются фундаментальными основами, предопределяющими возможности горного предприятия отвечать современным вызовам мировой экономики при сохранении собственной экономической и производственной стабильности [1]. При этом сами вопросы эффективного управления качеством продукции горного предприятия непосредственно связаны со сте-

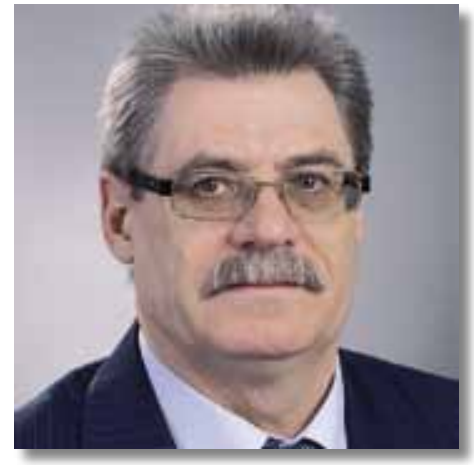

ГРИБ Николай Николаевич

Доктор техн. наук, профессор, заместитель директора по научной работе,

заведующий кафедрой «Горное дело» Технического института (ф) СВФу, 678960, г. Нерюнгри, Россия, e-mail:grib@nfygu.ru

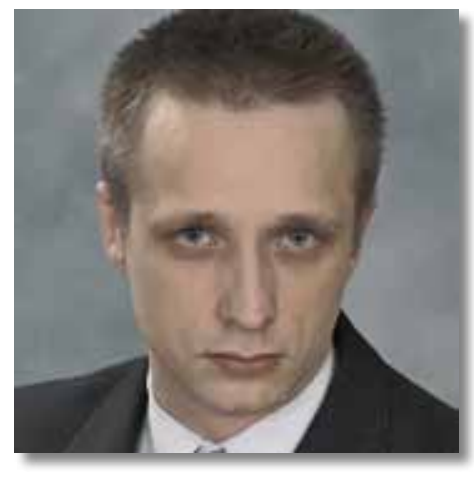

КУЗНЕЦОВ Павел Юрьевич

Канд. геол.-минер. наук, дочент, дочент кафедры «Горное дело» Технического института (ф) СВФУ, 678960, г. Нерюнгри, Россия, e-mail:kuznetsov.pavel.yu@gmail.com 
пенью изученности геологического строения месторождения и изменчивостью показателей качества угля, заключенного в недрах, по всей площади месторождения, принятого к отработке.

Учитывая представленное обстоятельство, можно обозначить, что одним из ключевых моментов при проектировании и вводе в эксплуатацию горного предприятия является наличие достоверных баз данных по качественным показателям полезного ископаемого, имеющих пространственную привязку по площади месторождения. Именно такие базы данных позволяют составить наиболее полное представление о состоянии изученности месторождения полезных ископаемых и предусмотреть необходимый объем дополнительных разведочных работ на месторождении в период его эксплуатации.

Как правило, планирование и проведение разведочных работ на стадии эксплуатации осуществляются за счет собственных средств горного предприятия и должны быть максимально эффективны как с точки зрения экономики, так и с точки зрения обеспечения возможности планирования и управления качеством продукции горного предприятия [2]. Достижение этого возможно при установлении оптимальной сети опробования (сети разведочных скважин), необходимой для уточнения качественных показателей добываемых полезных ископаемых, определяющих в дальнейшем эффективность технологических и рационально оправданных экономических решений [3]. При этом под оптимальной плотностью сети опробования, в контексте данной статьи, рассматривается такая густота сети (в частности такое расстояния между точками опробования (скважинами)), которая позволит повысить надежность, оперативность и эффективность решения технологических задач при управлении качеством продукции горного предприятия на стадии эксплуатации месторождения с возможностью оптимизации экономических затрат.

Как показано в работе [4], установление оптимальной плотности сети в современных условиях эксплуатации горных предприятий ограничивается выполнением рекомендации Федерального бюджетного учреждения «Государственная комиссия по запасам полезных ископаемых» (ГКЗ) по плотности сети опробования или основывается на практическом опыте ранее проведенных разведочных работ в аналогичных условиях [5].

Именно такой подход и обусловливает появление дополнительного проектного сгущения сетей опробования на стадии эксплуатации месторождения горным предприятием, только в случаях возникновения неопределенностей в ведении технологических процессов добычи полезного ископаемого на конкретных участках [6]. При этом возникновение неопределенностей при ведении технологических процессов добычи полезного ископаемого обусловлено различным сочетанием горно-геологических факторов и применением усредненных характеристик показателей качества полезного ископаемого и физикомеханических свойств без учета их пространственной изменчивости и неоднородности на этапе проектирования горных предприятий [7].

Эффективность решения обозначенного выше вопроса, как правило, связана с применением количественных методов проектирования сети опробования [8], которые напрямую связаны с детализацией геостатических моделей месторождений полезных ископаемых, которые активно применяются в настоящее время $[9,10,11]$. Но применение этих методов в условиях эксплуатации месторождения из-за экономии финансовых средств, как правило, опять же ограничивается площадью самого участка возникновения неопределенности и, соответственно, сгущение сети опробования проводится только для его условий.

Таким образом, рассмотренная выше ситуация с изученностью показателей качества полезного ископаемого предопределяет бессистемное сгущение сети опробования и ведет к нарушению структуры последовательного поэтапного нарастания разведочной информации до оптимальных объемов, обеспечивающих возможность эффективного управления качеством продукции горного предприятия и планированием горных работ. Учитывая это, можно логично прийти к выводу, что бессистемное принятие решений о плотности сети опробования неизбежно приведет к разноуровневой изученности месторождения в целом при явном уменьшении управленческой стабильности горного предприятия через невозможность планирования затрат на трудовые, материальные, энергетические и другие ресурсы [12].

Для россыпных и рудных месторождений одним из вариантов выхода из рассмотренной выше ситуации является создание оптимальной системы опробования на стадии опережающей эксплуатационной разведки на основе идей, высказанных в монографии доктором технических наук С.М. Ткачом (Институт горного дела Севера (О РАН), о кластерной организации месторождений [13].

Для угольных месторождений, как правило, при принятии решения об оптимальной плотности сети опробования на стадиях эксплуатационной разведки исходят в основном из понятия изменчивости показателей качества угля в целом по месторождению и ориентируются на создание регулярной сети опробования по всему месторождению с ориентированием на рекомендации ГК3 [14]. Применение регулярной сети является не всегда оправданным шагом, особенно для крупных угольных месторождений, на которых горно-геологические условия разработки месторождения характеризуются наличием тектоническими нарушений. Это связано с тем, что отдельные участки месторождения, разделенные тектоническим нарушениями, могут характеризоваться различными показателями изменчивости и неоднородности, а также степенью изученности показателей качества углей $[15,16]$. Учитывая данное обстоятельство, предлагается на основе идей о кластерной организации месторождений [13] в качестве основы для решения вопроса об оптимальной плотности сети опробования на стадиях эксплуатационной разведки угольных месторождений обеспечить переход от блоковой модели месторождения (деление относительно технических нарушений) к кластерной модели организации угольных месторождений. Такой переход позволит детализировать площадь угольного месторождения и получить самостоятельные сети эксплуатационного опережающего опро- 
бования с учетом ранее полученных данных по опробованию угля для каждого кластера в отдельности. В качестве примера реализации кластерного подхода к организации угольного месторождения в данной статье рассмотрено Эльгинское каменноугольное месторождение Южно-Якутского бассейна.

\section{КЛАСТЕРНАЯ ОРГАНИЗАЦИЯ ЭЛЬГИНСКОГО КАМЕННОУГОЛЬНОГО МЕСТОРОЖДЕНИЯ}

На угольных месторождениях опережающая эксплуатационная разведка ориентирована на уточнение показателей качества угля, морфологии угольного пласта и запасов полезного ископаемого, а также горно-технологических условий участка, подготавливаемого кдобычным работам. При этом результаты опережающей эксплуатационной разведки являются основным информационным обеспечением для текущего планирования и контроля за ведением горных работ, а сам процесс опережающих эксплуатационных разведочных работ осуществляется не на всем месторождении, а обеспечивает изучение только фронта горных работ, опережая непосредственно добычные работы на один-два года [17].

Из отмеченного выше, следует, что при планировании опережающей эксплуатационной разведки требуется уделять особое внимания определению оптимальных пространственно-геометрических параметров размещения разведочных скважин для достижения максимально эффективной увязки экономических затрат горного предприятия с поэтапным получением достоверной, представительной и полной информации о качестве намеченного к добыче полезного ископаемого.

Таким образом, учитывая рассмотренные выше задачи и требования к проведению опережающей эксплуатационной разведки месторождения, стоит заметить, что необходим переход на такую модель месторождения, которая бы позволила в достаточной степени оперативно (один два года) планировать проведение геологоразведочных работ на участках, в пределах которых осуществляется текущее и перспективное планирование горных работ. Причем такое планирование должно непосредственно учитывать данные о пространственной изменчивости и неоднородности этого участка по показателям качества угля. Для достижения этой цели разработан кластерный подход корганизации Эльгинского каменноугольного месторождения, основу которого составили идеи, изложенные в работах $[13,18]$.

При разработке подхода к определению оптимальной плотности сети разведочных скважин опережающей эксплуатационной разведки угольных месторождений на основе кластерного подхода необходимо обозначить следующие ключевые позиции, позволяющие представить угольное месторождение как кластерную систему:

- кластерная зона угольного месторождения - это обособленный в пространстве участок месторождения, определяемый в пространстве залеганием по падению угольных пластов на основе наличия на месторождении установленных осложняющих геологических факторов, особенностей морфологии рельефа месторождения и угольных пластов;
- кластерная зона геологоразведочного профиля это обособленный в пространстве участок месторождения, определяемый в пространстве месторождения по простиранию угольных пластов зоной влияния геологоразведочного профиля, выделенного по результатам детальной стадии разведки месторождения;

- зона влияния геологоразведочного профиля - это участок месторождения, заключенный между профилем и близлежащими заданными геологоразведочными профилями, и равный по площади произведению длины профиля на сумму половин расстояний до близлежащих заданных геологоразведочных профилей;

- кластерная организация угольного месторождения - это система информационного представления угольного месторождения, представляющая собой его дифференциацию на зоны, опережающее эксплуатационное опробование которых позволяет обеспечить поэтапное получение достоверной и представительной информации о качестве намеченного к добыче полезного ископаемого в соответствии с этапами перемещения фронта горных работ.

При переходе к кластерной организации Эльгинского каменноугольного месторождения необходимо также учитывать наличие тектонических нарушений на месторождении $[16,20]$ и принятый порядок отработки месторождения и движения фронта горных работ [19]. На современном этапе рассматриваемое месторождение, как правило, представляется в виде самостоятельных участков (рис. 1) [16, 19].

Причем каждый из этих участков, в силу своей самостоятельности, должен характеризоваться индивидуальными показателями качества угля, что актуализирует инициализацию процедуры планирования плотности сети опробования опережающей эксплуатационной разведки для каждого участка в отдельности $[12,17]$.

Но при рассмотренном подходе к планированию разведочных работ совершенно не учитываются морфология рельефа и пространственное расположение угольных пластов в углевмещающей толще, что может существенно сказаться на суждениях о значениях показателей качества угля для выделенных участков. Таким образом, опираясь на рассмотренные выше ключевые позиции о кластерной организации месторождения, а также основные задачи, решаемые на опережающей эксплуатационной разведке, необходимо осуществить переход к системе кластерной организации месторождения, которая позволит более детально рассматривать выделенные участки Эльгинского месторождения.

В качестве примера рассмотрим переход на кластерную организацию участка 2 Эльгинского каменноугольного месторождения (рис. 2, 3).

На рис. 2 представлено разделение на четыре кластерные зоны участка 2 Эльгинского месторождения. При анализе рис. 2 можно заметить два типа специальных выделенных профилей: базовый профиль и кластерный профиль. Базовый тип профиля соответствует опорному профилю, заданному при проведении детальных разведочных работ, и залегает по падению угольных пластов. Кластерный тип профиля - это граница между кластерными зонами месторождения в пределах одного 


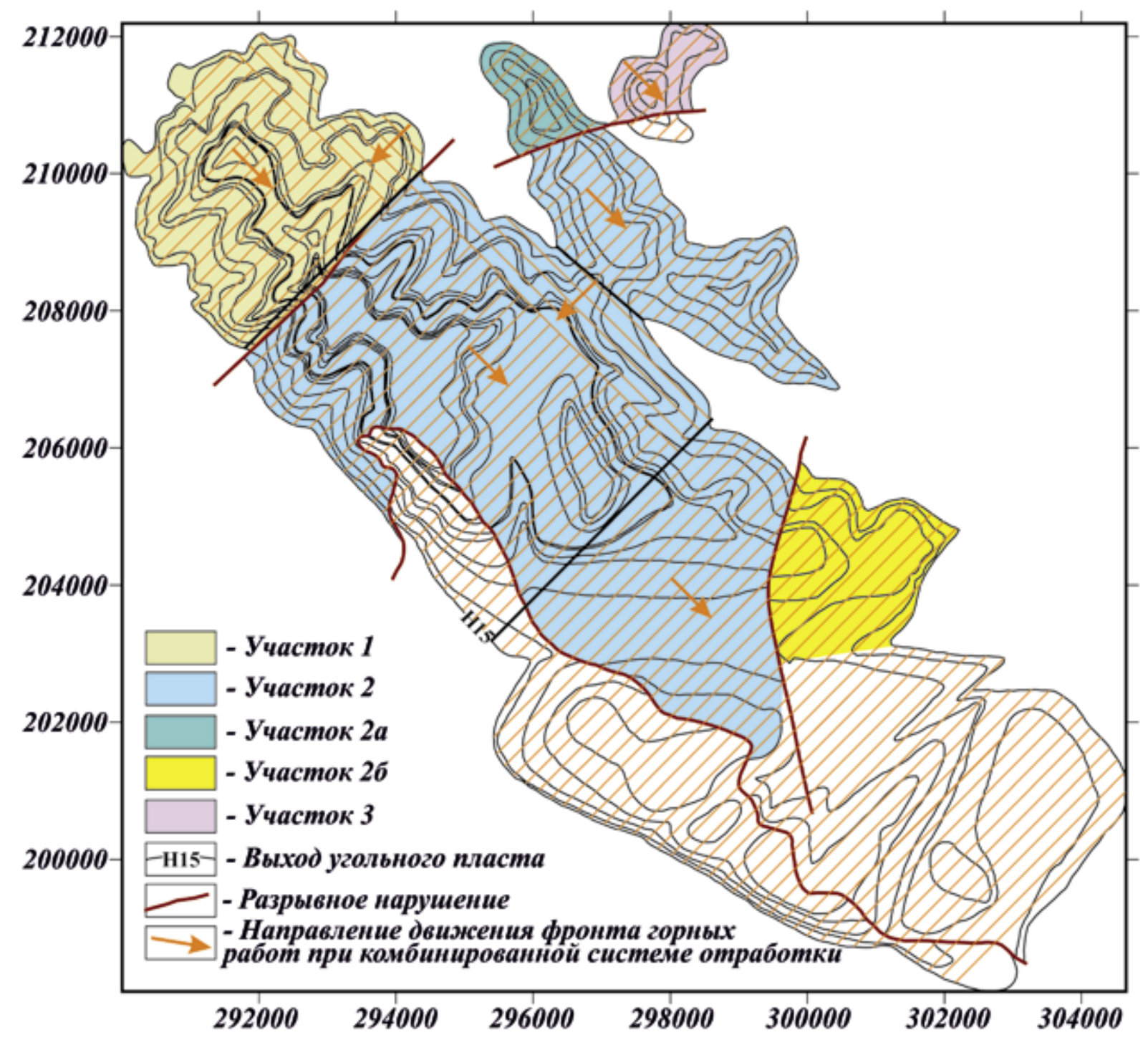

Рис. 1. Порядок отработки и участки Эльгинского каменноугольного месторождения

Fig. 1. The stoping sequence and sites of the Elga coal deposit

участка исследования, которая задается с учетом морфологии рельефа участка. Эти два типа специальных профилей позволяют выделить на участке месторождения самостоятельные кластерные зоны, а также обосновать начальную точку задания самостоятельных сетей разведочных скважин опережающей эксплуатационной разведки (точка пересечения базового и кластерного профилей). В случае отсутствия кластерного профиля (выдержанная морфология рельефа) в качестве начальной точки задания сети разведочных скважин опережающей эксплуатационной разведки принимается точка пересечения базового профиля с линией тектонического нарушения, ограничивающей участок месторождения.

На рис. 3 представлено разделение участка 2 Эльгинского каменноугольного месторождения на кластерные зоны геологоразведочных профилей. Такое представление кластерной организации участка позволяет однозначно судить о площади, которой характерны конкретные показа- тели качества угля, определяемые зоной влияния геологоразведочного профиля.

Опираясь на представленную в статье кластерную организацию участка 2 Эльгинского каменноугольного месторождения, можно перейти к созданию основы для планирования оптимальной плотности разведочных скважин опережающей эксплуатационной разведки для каждой выделенной кластерной зоны участка месторождения, опираясь на следующие принципы:

$>$ расчет оптимальных расстояний между профилями разведочных скважин на основе данных об изменчивости показателей качества угля осуществляется по направлению залегания по падению угольных пластов как направлению наименьшей изменчивости показателей качества угля [14] самостоятельно в пределах каждой выделенной кластерной зоны месторождения;

$>$ расчет оптимальных расстояний между разведочными скважинами осуществляется на основе данных об изменчивости показателей качества угля по направлению 
a)

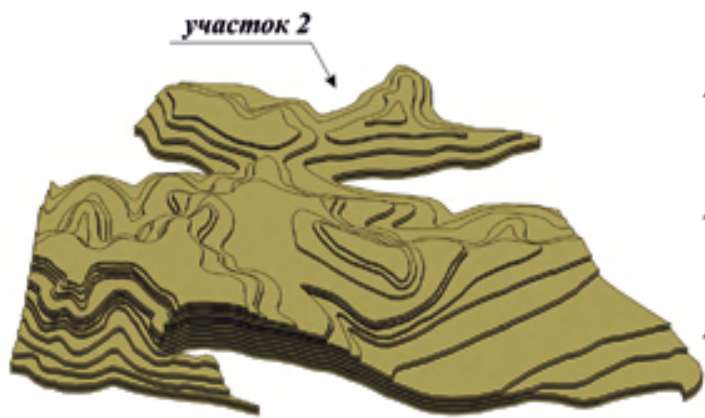

s)

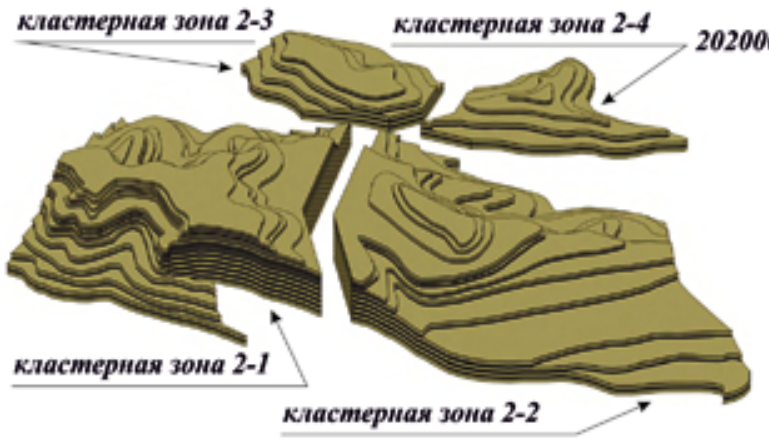

б)

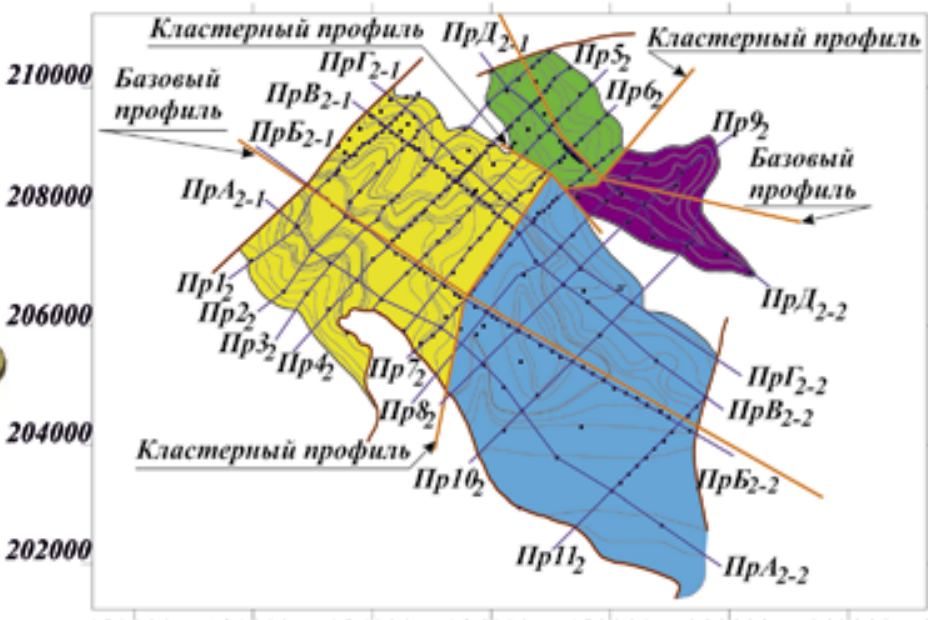

$290000 \quad 292000 \quad 294000 \quad 296000 \quad 298000 \quad 300000 \quad 302000$

Условные обозначения:

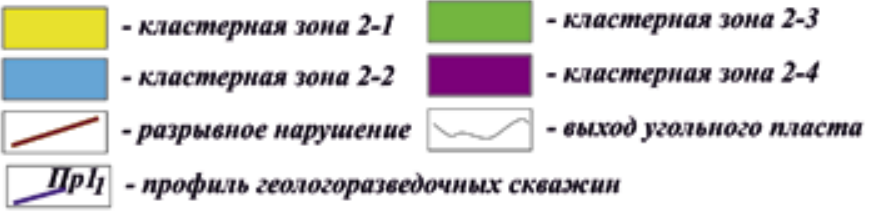

Примечамие: а) - объемиая модепь участка 2; б) - плановая модель разделеиия участка 2 па кластеры по падению угольиых пластов; в) - обьемная модель разделения участка 2 на кластеры по падению угольных пластов.

Puс. 2. Кластерные зоны Эльгинского каменноугольного месторождения участка 2

Fig. 2. Cluster zones of site 2 of Elga coal deposit

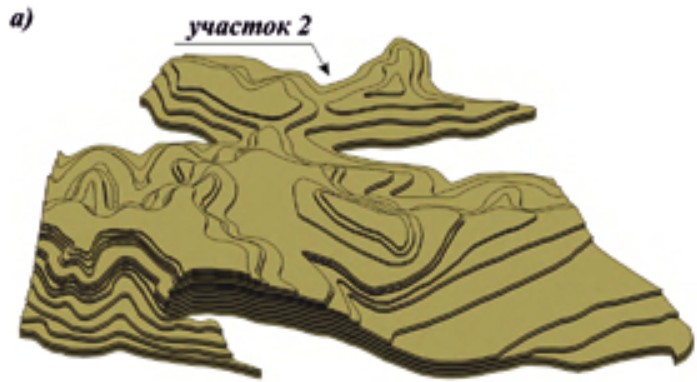

6)

кластерная зона Пр5 кластерная зона Пр кластерная зона Дрз

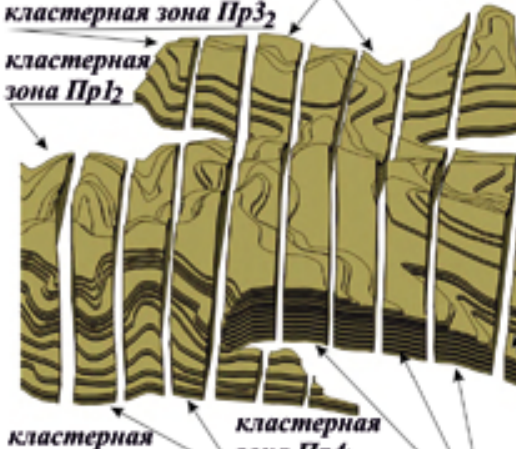

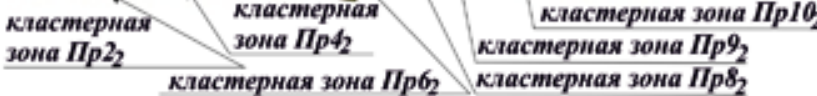

6)

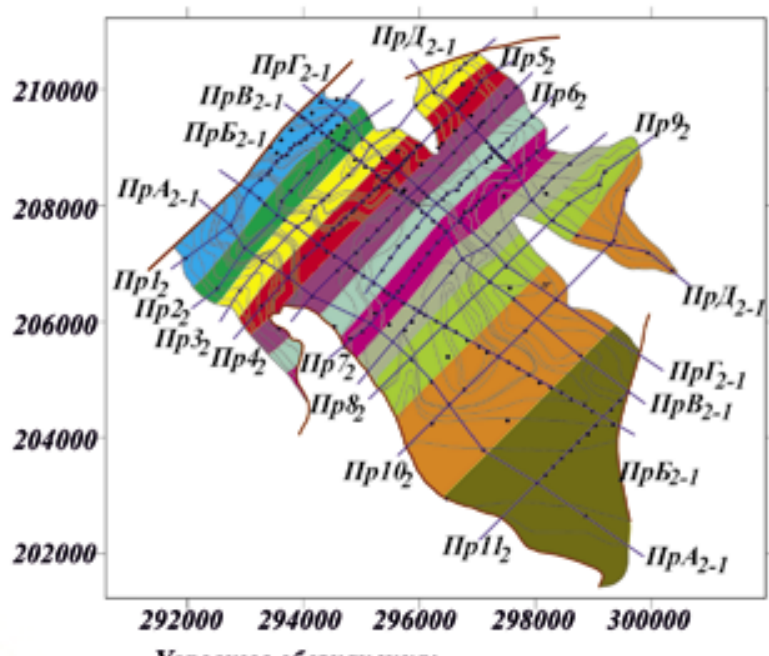

Условнме обозиачения:

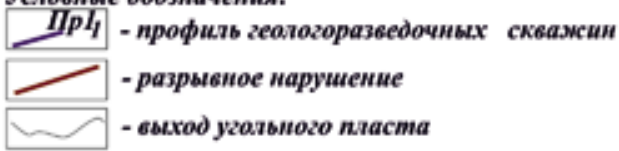

Примечание: a) - об̆емная модель участка 2; б) - пламовая модель разделения участка 2 на кластеры по простиранио угольных пластов; 6) - обьемиая модель разделения участка 2 па кластеры nо простираинь угальиых пластов

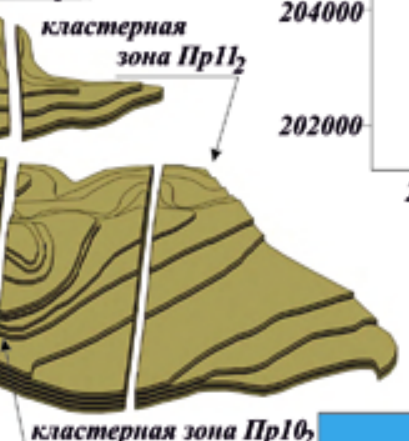

Рис. 3. Кластерные зоны геологоразведочных профилей Эльгинского каменноугольного месторождения участка 2

Fig. 3. Cluster zones of geological-prospecting profiles of site 2 of Elga coal deposit 
простирания угольных пластов как направлению наибольшей изменчивости показателей качества угля [14] самостоятельно в пределах каждой выделенной кластерной зоны геологоразведочных профилей;

$>$ в качестве начальной точки задания самостоятельных сетей разведочных скважин опережающей эксплуатационной разведки принимается точка пересечения базового профиля с кластерным профилем.

Также стоит отметить, что переход на кластерную организацию других участков Эльгинского каменноугольного месторождения осуществляется в той же последовательности, что и для участка 2, рассмотренного в статье.

\section{ЗАКЛЮЧЕНИЕ}

Кластерная организация угольного месторождения позволяет построить модель угольного месторождения на основе данных о результатах проведения доразведочных и детальных геологоразведочных работ, о тектонической обстановке на месторождении, о морфологии рельефа месторождения и угольных пластов, о порядке отработки месторождения и движения фронта горных работ.

При этом кластерная организация угольного месторождения обеспечивает создание эффективной основы вариативного планирования для кластерных структур самостоятельных оптимальных сетей опробования опережающей эксплуатационной разведки. Такой подход позволяет активно вовлекать в расчет сетей разведочных скважин количественные методы их расчета, обеспечивающие учет степени изученности участка месторождения, подготавливаемого в разработку на основе фактически оцененных данных о неоднородности изменчивости показателей качества углей.

Помимо указанного выше предложенный подход позволяет повысить эффективность перспективного и текущего планирования горных работ через управление ведением разведочных работ посредством учета последовательности отработки кластерных зон геологоразведочных профилей, что, несомненно, открывает широкие возможности для обеспечения процесса эффективного управления качеством угольной продукции на этапе подготовки участка к его отработке.

\section{Список литературы}

1. Nawrocki T.-L., Jonek-Kowalska I. Assessing operational risk in coal mining enterprises - Internal, industrial and international perspectives // Resources Policy. 2016. Vol. 48. Pp. 50-67. doi: 10.1016/j.resourpol.2016.02.008.

2. Stojanović C. Risk management model in surface exploitation of mineral deposits // Archives of Mining Sciences. 2016. Vol. 61(2). Pp. 293-308. doi: 10.1515/amsc-2016-0022.

3. Wellmer F.-W. Statistical Evaluations in Exploration for Mineral Deposits // Springer Science \& Business Media, 2012. 379 p. doi: 10.1007/978-3-642-60262-7-3.

4. Кузнецов П.Ю., Гриб Н.Н. Обоснование поэтапного подхода к выбору плотности сети разведочных скважин на стадии эксплуатации угольного месторождения / Проблемы комплексного освоения георесурсов // Горный информационно-аналитический бюллетень. 2016. № 8 (специальный выпуск 21). С. 462-475.
5. Ермолов В.А. Геология: учебник для вузов: в 2-х частях. Часть II: Разведка и геолого-промышленная оценка месторождений полезных ископаемых. М.: Издательство МГГУ, 2005. 392 с.

6. Soltani S., Safa M. Optimally Locating Additional Drill holes to Increase the Accuracy of Ore/Waste Classification // Mining Technology. Transactions of the Institutions of Mining and Metallurgy: Section A. 2015. Vol. 124(4). P. 213-221. doi: 10.1 179/1743286315Y.0000000009.

7. Marcelo G.. The effective management of geological risk in long-term production scheduling of open pit mines: $\mathrm{PhD}$ Thesis. School of Engineering, The University of Queensland, 2003. $256 \mathrm{p}$.

8. Лебедев Г.В. Методы определения параметров систем опробования // Вестник Пермского университета. Геология. 2007. Вып. 4 (9). С. 76 - 90.

9. Bertoli O, Paul A, Casley Z, Dunn D. Geostatistical drillhole spacing analysis for coal resource classification in the Bowen Basin, Queensland // International Journal of Coal Geology. 2013. Vol. 112. Pp. 107-113. doi: 10.1016/j.coal.2012.12.010.

10. Saikia K, Sarkar B. Coal exploration modelling using geostatistics in Jharia coalfield, India // International Journal of Coal Geology. 2013. Vol. 112. Pp. 36-52. doi: 10.1016/j. coal.2012.11.012.

11. Mai N.L., Erten O., Topal E. A new generic open pit mine planning process with risk assessment ability // International Journal of Coal Science \& Technology. 2016. Vol. 3(4). Pp. 407417. doi: 10.1007/s40789-016-0152-z.

12. Милютин А.Г. Разведка и геолого-экономическая оценка месторождений полезных ископаемых: учеб. пособие. М.: МГОУ, 2003.

13. Ткач С.М. Методологические и геотехнологические аспекты повышения эффективности освоения рудных и россыпных месторождений Якутии. Якутск: Издательство Института мерзлотоведения СО РАН, 2006. 284 с.

14. Методические рекомендации по применению классификации запасов месторождений и прогнозных ресурсов твердых полезных ископаемых. Угли и горючие сланцы. М.: ФГУ ГКЗ, 2007. 34 с.

15. Гриб Н.Н., Кузнецов П.Ю. Оценка изученности показателей качества угля Эльгинского месторождения //Уголь. 2016. № 9. C. 72-77. URL: http://www.ugolinfo.ru/Free/092016. pdf (дата обращения: 15.01.2018).

16. Кузнецов П.Ю., Гриб Н.Н., Скоморошко Ю.Н. Оценка неоднородности и пространственной изменчивости показателей качества углей // Горный журнал. 2017. № 3. С. 47-54.

17. Поиски и разведка месторождений полезных ископаемых: учебник для вузов / В.В. Авдонин, Г.В. Ручкин, Н.Н. Шатагин и др. М.: Академический Проект, Фонд «Мир», 2016. 544 c. URL: http://www.iprbookshop.ru/60034.html (дата обращения: 15.01.2018).

18. Гитис Л.Х. Статистическая классификация и кластерный анализ. М.: Издательство МГГУ, 2003. 157 с.

19. Технологический регламент отработки Эльгинского каменноугольного месторождения. Екатеринбург:ГУ ИГД УрО РАН, 2009. 129 c.

20. Угольная база России. Т. 5, кн. 2: Угольные бассейны и месторождения Дальнего Востока России (Республика Саха, Северо-Восток, о. Сахалин, п-ов Камчатка). М.: Геоинформмарк, 1999. 638 с. 
UDC 550.8.013(571.56) @ N.N. Grib, P.Yu. Kuznetsov, 2018

ISSN 0041-5790 (Print) • ISSN 2412-8333 (Online) • Ugol' - Russian Coal Journal, 2018, № 2, pp. 81-87

Title

CLUSTER-BASED ARRANGEMENT OF THE DEPOSIT AS A BASIS OF THE PLANNING REASONABLE DENSITY OF COAL WELLS

DOI: http://dx.doi.org/10.18796/0041-5790-2018-2-81-87

\section{Authors}

Grib N.N. ${ }^{1}$, Kuznetsov P.Yu.

${ }^{1}$ Technical Institute (branch) of M.K. Ammosov North-Eastern Federal University (TI (b) NEFU), Nerungry, 678960, Russian Federation

\section{Authors' Information}

Grib N.N., Doctor of Engineering Sciences, Professor, Deputy Director for Science, Head of the Department of mining, e-mail: grib@nfygu.ru Kuznetsov P.Yu., PhD (Geological-mineralogical), Associate Professor of the Department of mining, e-mail: kuznetsov.pavel.yu@gmail.com

\section{Abstract}

The relevance of the research is related to the issues of ensuring effective management of the quality of coal output in the field exploitation towards ensuring efficient planning of pre-mining grade control drilling as a tool to obtain total information about the qualitative indicators of a mineral. The planning process of pre-mining grade control drilling is primarily focused on: available data handling of the deposit; on the allocation of mining-and geological factors affecting the variability and heterogeneity of coal quality indicators in the rock massif; stoping sequence of mineral deposits. In view of this, as well as the tasks facing pre-mining grade control drilling, the issue of placement of test pits along the deposit area to ensure maximum informativeness of the process of advancing the mining front depends on the field model providing the representation of the coal deposit as an object of study. Thus, the field model which will be adopted at the field development stage by the mining enterprise will subsequently have a significant impact on the effectiveness of coal product quality management and the ability to vary solutions in the current planning and control of mining operations at the field. Object of research is coal-bearing massif of the Elga coal deposit of the South Yakutian embayment within the coal seams taken for open mining. Research results. An approach to the cluster-based arrangement of coal deposits has been developed. The following definitions are given for coal deposits: cluster-based arrangement of a coal deposit; a cluster zone of a coal deposit; a cluster zone of geological-prospecting profile; zone of influence of geological prospecting profile; basic and cluster profile. Based on the cluster arrangement of the coal field the main principles for planning reasonable density of coal wells for pre-mining grade control drilling are given. As an example the conversion to the cluster-based arrangement of site 2 of the Elga coal deposit is presented.

Figures:

Fig. 1. The stoping sequence and sites of the Elga coal deposit

Fig. 2. Cluster zones of site 2 of Elga coal deposit

Fig. 3. Cluster zones of geological-prospecting profiles of site 2 of Elga coal deposit

\section{Keywords}

Elga coal deposit, Cluster-based arrangement of coal deposit, Cluster zone of a coal deposit, Cluster zone of geological-prospecting profile, Zone of influence of geological prospecting profile, Basic profile and cluster profile, Pre-mining grade control drilling.

\section{References}

1. Nawrocki T.-L., Jonek-Kowalska I. Assessing operational risk in coal mining enterprises - Internal, industrial and international perspectives. Resources Policy, 2016, Vol. 48, pp. 50-67. doi: 10.1016/j.resourpol.2016.02.008.

2. Stojanović C. Risk management model in surface exploitation of mineral deposits. Archives of Mining Sciences, 2016, Vol. 61(2), pp. 293-308. doi: 10.1515/ amsc-2016-0022.

3. Wellmer F.-W. Statistical Evaluations in Exploration for Mineral Deposits Springer Science \& Business Media, 2012, 379 p. doi: 10.1007/978-3-642-60262-7-3. 4. Kuznetsov P.Yu. \& Grib N.N. Obosnovanie poehtapnogo podkhoda k vyboru plotnosti seti razvedochnykh skvazhin na stadii ehkspluatatsii ugol'nogo mestorozhdeniya. Problemy kompleksnogo osvoeniya georesursov [Substantiation of the staged approach to exploratory grid interval selection at the stage of coal deposit operation. Georesources integrated development issues.]. Gornyy Informatsionno-Analiticheskiy Byulleten'-Mining Information and Analytical Bulletin, 2016, No. 8 (Special issue 21), pp. 462-475.
5. Ermolov V.A. Geologiya: Uchebnik dlya vuzov: V 2-kh chastyakh. CHast' II: Razvedka i geologo-promyshlennaya otsenka mestorozhdenij poleznykh iskopaemykh [Geology: Textbook for higher educational establishments: In 2 parts. Part II: Exploration and geological-industrial estimation of mineral deposits]. Moscow, MSMU Publ., 2005, 392 p.

6. Soltani S. \& Safa M. Optimally Locating Additional Drill holes to Increase the Accuracy of Ore/Waste Classification. Mining Technology. Transactions of the Institutions of Mining and Metallurgy: Section A, 2015, Vol. 124(4), pp. 213-221. doi: 10.1179/1743286315Y.0000000009.

7. Marcelo G.. The effective management of geological risk in long-term production scheduling of open pit mines: PhDThesis. School of Engineering, The University of Queensland, 2003. 256 p.

8. Lebedev G.V. Metody opredeleniya parametrov sistem oprobovaniya [Methods of testing systems parameters definition]. Vestnik Permskogo universiteta. Geologiya - Perm University Newsletter. Geology, 2007, Vol. 4(9), pp. 76-90. 9. Bertoli O., Paul A., Casley Z. \& Dunn D. Geostatistical drillhole spacing analysis for coal resource classification in the Bowen Basin, Queensland. International Journal of Coal Geology, 2013, Vol. 112, pp. 107-113. doi: 10.1016/j. coal.2012.12.010

10. Saikia K. \& Sarkar B. Coal exploration modelling using geostatistics in Jharia coalfield, India. International Journal of Coal Geology, 2013, Vol. 112 pp. 36-52. doi: 10.1016/j.coal.2012.11.012.

11. Mai N.L., Erten O. \&Topal E. A new generic open pit mine planning process with risk assessment ability. International Journal of Coal Science \& Technology, 2016, Vol. 3(4), pp. 407-417. doi: 10.1007/s40789-016-0152-z.

12. Milyutin A.G. Razvedkaigeologo-ehkonomicheskaya otsenka mestorozhdenij poleznykh iskopaemykh: uchebnoe posobie [Exploration and geological-economic estimation of mineral deposits: textbook]. Moscow, MGOU Publ., 2003. 13. Tkach S.M. Metodologicheskie i geotekhnologicheskie aspekty povysheniya ehffektivnostiosvoeniya rudnykh irossypnykh mestorozhdenij Yakutii [Methodological and geotechnological aspects of increase of efficiency of development of ore and placer deposits of Yakutia]. Yakutsk, Institut merzlotovedeniya SB RAS Publ., 2006, 284 p.

14. Metodicheskie rekomendatsiipo primeneniyu klassifikatsii zapasov mestorozhdenij i prognoznykh resursov tverdykh poleznykh isko $\neg$ paemykh. Ugli i goryuchie slantsy [Methodical recommendations on application of classification of reserves deposit and prognostic resources of solid minerals. Coal and oil shale]. Moscow, FGU GKZ Publ., 2007, 34 pp.

15. Grib N.N. \& Kuznetsov P.Yu. Otsenka izuchennosti pokazatelej kachestva uglya EHI'ginskogo mestorozhdeniya [Available Elgin coal deposit coal quality indicators assessment]. Ugol' - Russian Coal Journal, 2016, No. 9, pp. 72-77. Available at: http://www.ugolinfo.ru/Free/092016.pdf (accessed 15.01.2018). 16. Kuznetsov P.Yu., Grib N.N., Skomoroshko Yu.N. Otsenka neodnorodnosti i prostranstvennoj izmenchivosti pokazatelej kachestva uglej [Assessment of nonuniformity and spatial variability of coal quality indexes]. Gornyj zhurnal - Mining Journal, 2017, No. 3, pp. 47-54. doi: 10.17580/gzh.2017.03.09. 17. Avdonin V.V., Ruchkin G.V., Sharagin N.N. et. al. Poiski i razvedka mestorozhdenijpoleznykh iskopaemykh. EHlektronnyj resurs. Uchebnik dlya vuzov [Prospecting and exploration of mineral deposits. Electronic resource. Textbook for high schools]. Moscow, Academic Proekt, Found "Mir" Publ., 2016, 544 p. Available at: http://www.iprbookshop.ru/60034.html (accessed 15.01.2018) 18. Gitis L.Kh. Statisticheskaya klassifikatsiya i klasternyj analiz [Statistical classification and cluster analysis]. Moscow, MSMU Publ., 2003, 157 p.

19. Tekhnologicheskij reglament otrabotki EHI'ginskogo kamennougol'nogo mestorozhdeniya [Process regulations for mining the Elga coal Deposit]. Ekaterinburg, GU IGD UrO RAN Publ., 2009, 129 p.

20. Ugol'naya baza Rossii. T.5, kn.2: Ugol'nye bassejny i mestorozhdeniya Dal'nego Vostoka Rossii (Respublika Sakha, Severo-Vostok, o. Sakhalin, p-ov Kamchatka) [The coal base of Russia. Vol.5, book 2: Coal basins and deposits of the Russian Far East (Republic of Sakha, northeast, Sakhalin island, Kamchatka Peninsula)]. Moscow, Geoinformmark Publ., 1999, 638 p. 


\section{Аспекты ликвидации шахт Прокопьевско- Киселевского угольного месторождения}

DOI: http://dx.doi.org/10.18796/0041-5790-2018-2-88-94

\author{
БЫКАДОРОВ Алексей Иванович \\ Канд. техн. наук, \\ Генеральный директор \\ ООО «Сибирский институт геотехнических \\ исследований», \\ 653000, г. Прокопьевск, Россия, \\ e-mail:priem_sigi@mail.ru
}

\section{ЧЕРНУХА Александр Владимирович}

Заместитель начальника Управления маркшейдерии, геологии и охраны природы ФГБУ «ГУРШ»,

127254, г. Москва, Россия,

e-mail:chav@gursh.ru

\section{СВИРКО Сергей Владимирович}

Заведующий лабораторией охраны инженерных

и природных объектов

ООО «Сибирский институт геотехнических

исследований»,

653000, г. Прокопьевск, Россия,

e-mail: svirko@ngs.ru

Рассмотрен техногенный гидрогеологический комплекс, включающий действующие, консервируемые и ликвидируемые предприятия угледобычи на территории городов Прокопьевска и Киселевска Кемеровской области. Определены вероятные негативные гидрогеологические, газодинамические и геомеханические последствия, связанные сликвидацией и затоплением шахт Прокопьевско-Киселевского угольного района. Выполнен анализ сложившейся гидрогеологической ситуации с учетом перспективы развития открытых горных работ.

Ключевые слова: техногенный комплекс гидравлически связанных шахт, отметка гидравлической связи, уровень затопления шахты, водоотливной комплекс, откачка, прогноз развития гидрогеологической ситуации, подтопление поверхности, геомеханические прочессы и явления, гидромониторинг.

\section{ВВЕДЕНИЕ}

В границах Прокопьевско-Киселевского месторождения каменных углей расположены горные отводы 22 шахт, девять из которых находятся в пределах городской черты г. Киселевска: «Тайбинская», «Суртаиха», им. Вахруше- ва, «Киселевская», «Красный Кузбасс», «Дальние Горы», «Черкасовская», № 12 и «Краснокаменская»; 13 - в черте города Прокопьевска: «Тырганская», «Зиминка», «Красногорская», им. Калинина, им. Ворошилова, им. Дзержинского, «Зенковская», «Ноградская», «Коксовая», «Центральная», «Северный Маганак», «Красный Углекоп» и «Смычка» (см. рисунок).

По состоянию на декабрь 2017 г. единственной действующей шахтой Прокопьевско-Киселевского угольного района остается шахта им. Дзержинского, осуществляющая производство подземных горных работ на гор. +20 м. Остальные шахты либо уже ликвидированы, либо находятся на стадии консервации и планируются к ликвидации.

Как известно, закрытие шахт сопровождается изменением их антропогенного воздействия на окружающую среду с возникновением новых негативных явлений и процессов, которых не было в период эксплуатации предприятий. В условиях характерных особенностей ПрокопьевскоКиселевского месторождения с его высокой концентрацией угледобывающих предприятий, гидравлически связанных между собой, достаточно плотной застройки поверхности ликвидируемых шахтных полей и ведения открытой добычи на горных отводах шахт, ликвидированных полным или частичным затоплением, экологически опасными являются процессы [1, 2, 3, 4, 5, 6, 7, 8, 9]:

- подтопление участков жилой и промышленной застройки;

- перетоки подземных вод из затопленных шахт в действующие предприятия открытой и подземной добычи;

- загрязнение подземных водоносных горизонтов и питьевых водозаборов, находящихся в зоне действия промышленных объектов;

- деформации поверхности от просадочных явлений;

- неуправляемое выделение газов (метано-воздушная смесь, продукты окисления от эндогенных пожаров и другое) из ликвидированных горных выработок.

Указанная специфика требует всестороннего анализа ситуации, обоснованного проведения мероприятий, максимально снижающих риски в процессе ликвидации и затопления шахт Прокопьевско-Киселевского угольного района и должного контроля.

Гидрометрические особенности ПрокопьевскоКиселевского месторождения обусловливают деление всей совокупности шахт района на обособленные группы. Так гидравлическая связь шахт «Тырганская» и им. Ка- 


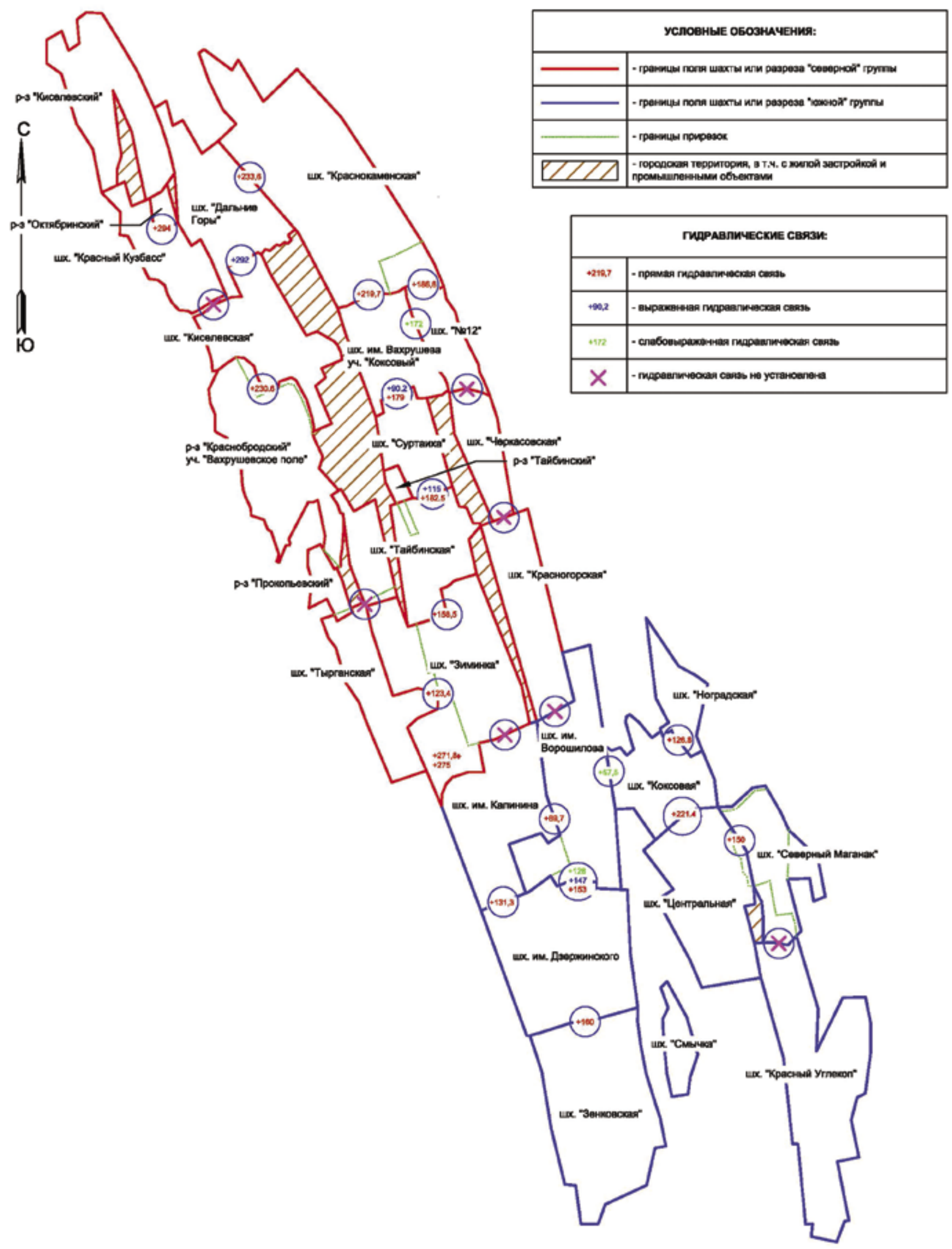

Схема расположения шахтных полей Прокопьевско-Киселевского месторождения каменного угля Fig. Prokopyevsko-Kiselyovskoye coal deposit mine-takes layout 
линина на отметках гор. +272 м и выше, изолированность шахт «Зиминка» и «Красногорская» от шахт им. Калинина и им. Ворошилова, существующий рельеф поверхности, а также разные темпы развития открытых работ по полям ликвидированных шахт г. Прокопьевска и г. Киселевска и, как следствие, разные точки разгрузки подземных вод позволяют выделить в месторождении две группы: северную и южную.

В северную группу шахт входят гидравлически связанные шахты «Тырганская», «Тайбинская», им. Вахрушева, «Суртаиха», «Черкасовская», «Зиминка», № 12, «Краснокаменская» (ОАО «Поляны»), «Дальние горы» (ОАО «Луговое»). К северной группе отнесены также гидравлически обособленная шахта «Красногорская» и шахта «Киселевская», граничащая с Краснобродским угольным разрезом (участок «Вахрушевское поле») через вскрытые разрезом выработки горизонта +220 м, а также шахта «Красный Кузбасс», водопритоки которой истекают в выработки открытых работ разреза «Октябринский».

Южная группа шахт объединяет шахты «Ноградская», «Центральная», «Северный Маганак», «Коксовая-2», им. Калинина, им. Ворошилова, им. Дзержинского и «Зенковская». К южной группе также относятся изолированные шахты «Смычка» и «Красный Углекоп», режим затопления которых не влияет на общую гидрогеологическую ситуацию Прокопьевско-Киселевского угольного района. Водопонижение на шахтах «Смычка» и «Красный Углекоп» по условию безопасности городской жилой застройки контролируется муниципальными службами г. Прокопьевска.

Помимо деления шахт на северную и южную группы целесообразно дополнительное деление южной группы на западный (шахты им. Калинина, им. Ворошилова, им. Дзержинского, «Зенковская») и восточный (шахты «Ноградская», «Коксовая-2», «Центральная», «Северный Маганак», а также обособленные шахты «Смычка» и «Красный Углекоп») кусты, что обусловлено нижеследующим обстоятельством.

Между шахтами им. Ворошилова и «Коксовая-2» прямых гидравлических связей не установлено. Гидравлическая связь на уровне незначительной фильтрации (до $\left.10 \mathrm{~m}^{3} / 4\right)$ оценивается возможной на отметке $+57,5$ м через породный целик размером 5,5-6 м между забоем квершлага гор. +50 м шахты им. Ворошилова и кровлей пласта VI Внутреннего шахты «Коксовая-2» и слежавшийся закладочный массив.

В пользу слабовыраженности связи свидетельствует анализ графиков затопления подземных выработок шахт «Коксовая-2» и им. Ворошилова за 2015 г. При превышении уровня затопления шахты им. Ворошилова отметки $+57,7$ м (абс.) и его росте до +100 м (абс.) заметного падения скорости затопления шахты им. Ворошилова, которое наблюдалось бы в случае существенных перетоков воды между шахтами, не установлено. Характер затопления шахты «Коксовая-2» в этот период времени носит случайный характер, поскольку для ускорения подтопления основных горных выработок гор. +65 м шахты с целью исключения аэродинамической связи и локализации эндогенного пожара дополнительно использовались воды р.
Аба. Таким образом, при отсутствии прямой гидравлической связи западные и восточные шахты южной группы следует рассматривать обособленно.

Уровень затопления западного куста южной группы гидравлически связанных шахт не может превысить отметки +258 - +262 м, так как в этом случае шахтные воды выйдут на поверхность в самом низком месте Прокопьевско-Киселевского угольного района - на горном отводе шахты «Зенковская». При этом гидравлическая связь между крайней шахтой южной группы - шахтой им. Калинина и смежной шахтой северной группы шахтой «Тырганская» может возникнуть только на отметке +272 м и выше.

Уровень затопления шахты «Коксовая-2», крайней в восточном кусту южной группы шахт, не должен превышать отметки +125 м (абс.) по условию охраны промышленных и гражданских зданий, сооружений и коммуникаций, расположенных в центре г. Прокопьевска, в том числе железной дороги РЖД (МПС).

В случае прекращения водоотведения на шахте «Коксовая-2» с соответствующими последствиями для объектов поверхности областью разгрузки шахтовых вод через каскад перетоков «Коксовая-2» - «Центральная» - «Северный Маганак» (на отметках +221,4 м и +150 м соответственно) станет карьерная выемка ООО «Разрез «Березовский», производящего открытую доработку запасов в границах горного отвода ликвидированной шахты «Северный Маганак». То есть уровень затопления восточного куста и всей южной группы шахт в целом не достигнет отметки перетока +272 м.

В свою очередь северная группа шахт вследствие прямых гидравлических связей на установленных отметках будет разгружаться в выработки открытых работ, расположенных по полям ликвидированных шахт г. Киселевска, то есть уровень затопления северной группы гидравлически связанных шахт также не достигнет отметки перетока $+272 \mathrm{M}$.

Следовательно, по гидрометрическим условиям в Прокопьевско-Киселевском месторождении выделяются обособленные группы шахт:

- южная группа шахт:

- западная ветвь южной группы (шахты им. Калинина, им. Ворошилова, им. Дзержинского и «Зенковская»);

- восточная ветвь южной группы (шахты «Ноградская», «Коксовая-2», «Центральная», «Северный Маганак», «Смычка» и «Красный Углекоп»);

- северная группа шахт: «Тырганская», «Тайбинская», им. Вахрушева, «Суртаиха», «Черкасовская», «Зиминка», № 12, «Краснокаменская», «Дальние горы», «Красногорская», «Киселевская» и «Красный Кузбасс».

\section{ЗАПАДНАЯ ВЕТВЬ ЮЖНОЙ ГРУППЫ ШАХТ}

Гидрогеологический режим западной ветви южной группы шахт (им. Калинина, им. Ворошилова, им. Дзержинского и «Зенковская») обусловливается прямыми гидравлическими связями шахт между собой, производством водоотведения на шахте им. Дзержинского и откачкой водопритоков в выработках смежных ликвидируемых шахт (им. Калинина, им. Ворошилова и «Зенковская») по усло- 
вию безопасности действующей шахты им. Дзержинского. При этом техногенно-нарушенный массив остается осушенным на глубину 150 м и более.

В случае принятия решения по ликвидации шахты им. Дзержинского потребуется сохранение водоотливных комплексов с их усилением для приема водопритоков с шахты им. Дзержинского с целью обеспечения безопасности открытых горных работ, планируемых на полях шахт «Зенковская» до гор. +150 м и им. Дзержинского до гор. $+140 \mathrm{M}$.

В результате многолетнего ведения горных работ и действия водоотливов в пределах шахтных полей произошло снижение уровней подземных вод и сформировалась депрессионная воронка. При полном отказе от производства горных работ и прекращении водоотведения на шахтах им. Дзержинского, им. Калинина, им. Ворошилова и «Зенковская» инициируется процесс «залечивания» депрессионной воронки, при котором уровень подземных вод будет повышаться. С учетом прямых сбоек шахт горными работами подъем уровня подземных вод в пределах шахтных полей будет формироваться по принципу сообщающихся сосудов до самоизлива шахтных вод на поверхность в точках с минимальными высотными отметками.

На горном отводе шахты «Зенковская» имеются наиболее низко расположенные участки поверхности западной ветви южной группы гидравлически связанных шахт Прокопьевско-Киселевского техногенного гидрогеологического комплекса. Долине р. Щербаковка, пересекающей шахтное поле с запада на восток, соответствует отметка +258 м, кроме того, шахтные воды могут выйти в районе лога ручья Бескулачиха на отметке около +258 м и лога ручья Мокина на отметке $+258 \mathrm{~m}$.

При реализации ликвидации шахт полным затоплением с самоизливом шахтных вод на горном отводе шахты «Зенковская» от подтопления шахтными водами, а также в результате подъема уровня грунтовых вод могут пострадать до 900 частных жилых домов и 40 многоэтажных зданий, расположенных в правобережной части р. Аба (отметки $+242-+244$ м) к востоку от горного отвода шахть «Зенковская».

Принимая во внимание прямые гидравлические связи между вышеуказанными шахтами, уровень затопления шахт им. Калинина, им. Ворошилова и им. Дзержинского с учетом гидравлического сопротивления шахтовых перемычек составит $+258-+262 \mathrm{M}$.

В восточной части горного отвода шахты им. Дзержинского, а также на территории, расположенной ниже по рельефу от горного отвода шахты, на правом берегу р. Аба (отметка +246 - +256 м), от подтопления шахтными водами, а также в результате подъема уровня грунтовых вод могут пострадать до 800 частных домовладений и около 20 многоэтажных зданий.

В результате ухудшения дренирования и подпора грунтовых вод с учетом большой мощности покровных суглинков и их низких фильтрационных свойств, приводящих к эффекту заболачивания, в зону подтопления попадут и жилые поселки, расположенные на горном отводе шахты им. Ворошилова (минимальная отметка застройки - +269,9 м).
Исходя из вышеизложенного, в случае полной ликвидации шахт и прекращения работ по водоотведению от подтопления шахтными водами может пострадать значительное количество объектов жилой и промышленной городской застройки, большая часть которой расположена вне пределов горных отводов. С учетом отметок жилой и промышленной застройки, расположенных вне горных отводов шахт им. Дзержинского и «Зенковская» ниже по рельефу (отметка +242 м и выше), по условию разрыва водоносных горизонтов подземных вод и вод четвертичных отложений уровень водопонижения западного куста южной группы шахт не должен превышать отметки $+210 \mathrm{~m}$.

При этом ввиду значительности объемов перетока между шахтами и сложностей их сброса в речную сеть вследствие ограниченной пропускной способности подземных и поверхностных водотоков, возможно, потребуется несколько отдельных точек водопонижения.

\section{ВОСТОЧНАЯ ВЕТВЬ ЮЖНОЙ ГРУППЫ ШАХТ}

Поле шахты «Коксовая-2» (ранее шахта «Коксовая»), расположенное в восточной части южной группы ликвидируемых шахт района, имеет минимальные отметки поверхности в своей западной части (+261,6 - +263 м). Несколько выше (до +265 - +266 м) отметки южнее, в долине р. Аба.

В границах влияния горных работ шахты «Коксовая-2» расположены капитальная жилая застройка центра г. Прокопьевска, промышленные здания и сооружения, электрифицированная железная дорога РЖД, автобаза и другие объекты, которые подрабатывались шахтой «Коксовая-2» с использованием различных видов закладки отработанного пространства с усадкой от 5\% (литая твердеющая) до 30\% (коренные породы Усятской свиты).

Помимо подтопления, возникающего при ликвидации шахт, могут появиться новые негативные проблемы, вызванные изменением характера деформирования земной поверхности, в частности активизацией процесса сдвижения. Активизацией процесса сдвижения принято считать дополнительное сдвижение массива горных пород и земной поверхности над старыми очистными выработками под воздействием некоторого активизирующего фактора. Механизм активизации процесса сдвижения на ликвидируемых шахтах имеет другую природу, в отличие от повторной подработки земной поверхности при переходе горных работ на нижние горизонты, и обусловлен снижением прочностных свойств увлажненных горных пород при затоплении выработанного пространства шахтными водами, возобновлением процесса их обрушения и заполнением пустот и расслоений, сохранившихся в подработанной толще. Обводнение горных пород резко снижает их устойчивость - породы размокают, становятся склонными к сползанию.

В условиях активизации процессов сдвижения при полном затоплении шахты «Коксовая-2» возможно негативное геомеханическое влияние на вышеуказанные объекты поверхности, прогноз которого весьма затруднителен - методик расчета ожидаемых деформаций подработанного массива горных пород и земной поверхности для условий 
Кузбасса после ликвидации (консервации) шахты способом затопления не существует. Для их разработки нет достаточных инструментальных наблюдений за поведением техногенного массива затопленных шахт.

Поэтому, как уже было сказано ранее, по условию охраны промышленных и гражданских зданий, сооружений и коммуникаций уровень затопления шахты «Коксовая-2», крайней в восточном кусту южной группы шахт, не должен превышать отметки +125 м (абс.).

С учетом проводимого водопонижения на шахте «Коксовая-2» до отметки +125 м подтопление объектов поверхности в границах влияния шахт «Ноградская», «Коксовая-2», «Центральная» и «Северный Маганак» не прогнозируется. При этом принимаем во внимание следующее:

- прямую гидравлическую связь шахт «Ноградская» и «Коксовая» на гор. +125 м (отметка $+126,8$ м) и на гор. +165 м (отметка +177 м) через разрушенные межэтажные целики на участке совместной отработки пласта VI Внутреннего, а также наличие на горном отводе шахты «Ноградская» остаточной карьерной выемки до гор. +230 м;

- прямые гидравлические связи шахт «Коксовая-2» и «Центральная» через сбойки горными работами гор. +215 м (минимальная отметка +221,4 м);

- прямые гидравлические связи шахт «Центральная» и «Северный Маганак» на прирезке через очистные выработки пласта Горелого на гор. +150 м;

- карьерную выемку ООО «Разрез «Березовский», расположенную в границах горного отвода ликвидированной шахты «Северный Маганак», с перспективными планами по открытой отработке запасов до проектной отметки +150 м. Доработка запасов в настоящее время осуществляется в целиках без предварительного снижения уровня затопления. В перспективе при развитии открытых работ в плане и по глубине ниже отметки затопления шахты «Северный Маганак» нельзя исключать поступление водопритоков шахт «Центральная» и «Северный Маганак» частично или полностью в открытые горные работы ООО «Разрез «Березовский».

Таким образом, с учетом водопонижения на обособленных шахтах «Смычка» и «Красный Углекоп», а также поддержания безопасного уровня на шахте «Коксовая-2» и перспектив развития открытых работ на ООО «Разрез «Березовский» подтопления жилой и промышленной застройки в границах влияния всех шахт восточного куста южной группы ожидать не следует.

В случае полного отказа от водопонижения угрозе гидрогеологических и геомеханических рисков подвергаются объекты поверхности, расположенные в зонах влияния шахт «Коксовая-2», «Центральная», «Красный Углекоп» и «Смычка». Жилая и промышленная застройка в границах горного отвода шахты «Северный Маганак» отсутствует.

\section{СЕВЕРНАЯ ГРУППА ШАХТ}

Складывающаяся гидрогеологическая ситуация в северной группе Прокопьевско-Киселевского угольного района определяется отметками прямых и явных гидравлических связей шахт между собой, а также ведением открытой угледобычи, в том числе на полях ликвидированных и консервируемых предприятий (шахты «Красный Кузбасс», «Дальние Горы», «Краснокаменская», им. Вахрушева, «Тайбинская», «Черкасовская» и № 12).

Так, например, гидрогеологическая ситуация на горных отводах и в техногенных горизонтах шахт «Тайбинская», «Суртаиха», им. Вахрушева, «Тырганская» и «Зиминка» контролируется ООО «Инвест-Углесбыт» и ООО «Участок «Коксовый», осуществляющих открытую доработку запасов в границах горных отводов ликвидированных шахт «Тайбинская» и им. Вахрушева до планируемых отметок - гор. +50 м и гор. \pm 0 м соответственно. Производство водопонижения выполняется по условию безопасности собственных открытых работ с целью исключения поступления значительных объемов воды в выработки открытых горных работ. ООО «Инвест-Углесбыт» осуществляет откачку погружными насосами, смонтированными в скиповом стволе шахты «Тайбинская». Безопасность выработок ООО «Участок «Коксовый» обеспечивается системой барьерной защиты, состоящей из скважин, пробуренных в подземные выработки шахт им. Вахрушева и «Суртаиха» и оборудованных погружными насосами, а также внутрикарьерным водоотливом участка. При осуществлении водопонижения меняется уровень затопления смежных шахт, гидравлически связанных на разных отметках с их вовлечением в общую гидросистему.

Контроль гидрогеологической ситуации на шахтах «Черкасовская» и № 12 осуществляется ООО «Шахта № 12», выполняющим производство открытых горных работ в целике между консервируемой шахтой № 12 и ликвидированной шахтой «Черкасовская» на гор. +220 м, по состоянию на декабрь 2017 г. водоотведение осуществляется подземным водоотливом гор. +100 м.

Шахта «Киселевская» ликвидируется подтоплением подземных горных выработок с организацией перепуска шахтовых вод в открытые горные работы Краснобродского угольного разреза (участок «Вахрушевское поле») ОАО «УК «Кузбассразрезуголь» на отметках +230,6 - +235 м с их дальнейшей откачкой в очистные сооружения разреза. При минимальных отметках естественной поверхности +319,5 м и выше на горном отводе шахты «Киселевская» самоизлива шахтных вод и подтопления поверхности ожидать не следует.Шахта «Красный Кузбасс» ликвидирована с истечением воды на отметке +294 м в выработки открытых горных работ разреза «Октябринский». Объем водопритоков, поступающих в выработки разреза достигает 70-80 м³/ч. При этом гидрогеологическая ситуация остается стабильной в течение длительного времени (более 15 лет).

Планами перспективного развития АО «Луговое» предусматривается ведение открытых работ на двух эксплуатационных участках до гор. +80 м в границах консервируемой шахты «Дальние Горы». Поэтому в качестве варианта консервации шахты принят «комбинированный» способ - с откачкой воды погружными насосами, расположенными в скипоклетевом стволе шахты. Для обеспечения безопасности ведения открытых работ будет выполняться опережающее понижение уровня затопления по отношению к открытым работам. В настоящее время шахта находится в режиме затопления. 
AO «Поляны» производит доработку открытым способом запасов углей пластов, отработанных подземным способом шахтой «Краснокаменская», в основном на их выходах, залегающих в северной части горного отвода предприятия. Проектная граница открытых работ - до гор. \pm 0 м. Управление уровнями подземных вод осуществляется стационарным шахтовым водоотливом гор. +100 м, т.е. техногенно-нарушенный массив остается осушенным на глубину 200 м и более.

При производстве открытых работ в затопленных контурах ликвидированных шахт ниже пьезометрической отметки подземных вод потребуется опережающее снижение уровней затопления в границах дорабатываемых участков, при котором уровни затопления смежных шахт, с которыми имеются гидравлические связи, также будут меняться. То есть в существующей ситуации и на ближайшую перспективу уровни затопления являются динамическими [10]. Так как горизонты открытых горных работ существенно ниже отметок дневной поверхности, что в свою очередь потребует поддержания соответственных уровней затопления ликвидируемых (консервируемых) шахт, подтопление объектов городской застройки исключается.

Шахта «Красногорская» ликвидируется «комбинированным» способом - затоплением до отметки +270 м, исключающей подтопление участков дневной поверхности. Проектом ликвидации предусмотрена установка погружных насосов в клетевом стволе шахты. В настоящее время шахта находится в режиме затопления, монтаж насосов не осуществлялся из-за существенных сроков затопления шахты (более пяти лет от начала затопления).

С целью недопущения поступления подземных вод из шахт северной группы в шахты южной группы в случае полного отказа от ведения открытых работ на полях ликвидированных шахт северной группы и прекращения откачки воды необходима организация в северной группе водоотливного комплекса с поддержанием уровня на определенной отметке, которая может быть установлена по анализу планов поверхности и геологических разрезов.

\section{МонИторИнг}

В рамках возможного возникновения гидрогеологических и геомеханических рисков при затоплении шахт Прокопьевско-Киселевского угольного района необходимо проведение регламентированных повторяющихся наблюдений за изменением состояния геологической среды - мониторинга подземных вод и мониторинга деформаций и сдвижений земной поверхности.

Необходимость гидромониторинговых наблюдений основана на возможном подтоплении территорий и неконтролируемых поступлений воды в выработки действующих предприятий открытой угледобычи. Мониторинг подземных вод включает производство периодических наблюдений за уровнями подземных вод, фиксацию производительности дренажных средств (погружных и других насосов) и их эксплуатационное состояние. По результатам этого вида мониторинга могут быть уточнены прогнозные оценки по гидродинамическому режиму затопления техногенных горизонтов шахт и откорректированы проектные решения и мероприятия по охране природных и инженерных объектов.

Необходимость мониторинговых наблюдений за деформациями и сдвижением земной поверхности обусловлена наличием на поверхности жилых домов, промышленных объектов и сооружений. Мониторинг деформаций и сдвижений земной поверхности включает вынесение инструментальными методами на поверхность горных отводов шахт прогнозных провалоопасных зон от вскрывающих, очистных и подготовительных выработок, их ограждение понятными знаками, систематический контроль состояния ограждений провалоопасных зон с целью их своевременной засыпки в случае их появления. На участках прогнозного подтопления поверхности, вблизи провалоопасных зон, на застроенных территориях, а также на участках выходов крутых пластов и труднообрушаемых кровель под наносы могут быть заложены профильные линии грунтовых реперов, по результатам инструментальных наблюдений за которыми определяются величины остаточных сдвижений и степень вредного влияния затопления шахты на охраняемые объекты.

\section{ЗАКЛЮЧЕНИЕ}

Вопросы безопасности открытых горных работ, проводимых по полям ликвидированных шахт ниже пьезометрической поверхности затопления (исключение поступления аварийных объемов водопритоков, устойчивость бортов и т.д.), необходимо решать в рамках отдельных локальных проектов отработки запасов.

\section{Список литературы}

1. Правила охраны сооружений и природных объектов от вредного влияния подземных горных разработок на угольных месторождениях. СПб, 1998.

2. Федеральный закон от 20.06.1996 № 81-Ф3 (ред. от 03.07.2016) «О государственном регулировании в области добычи и использования угля, об особенностях социальной защиты работников организаций угольной промышленности». URL: http://www.consultant.ru/document/ cons_doc_LAW_10849/ (дата обращения: 15.01.2018).

3. Федеральный закон от 21.07.1997 № 116-Ф3 (ред. от 07.03.2017) «О промышленной безопасности опасных производственных объектов» (с изм. и доп., вступ. в силу с 25.03.2017). URL: http://www.consultant.ru/document/cons_ doc_LAW_15234/ (дата обращения: 15.01.2018).

4. Приказ Ростехнадзора от 19.11.2013 № 550 (ред. от 08.08.2017) «Об утверждении Федеральных норм и правил в области промышленной безопасности «Правила безопасности в угольных шахтах» (Зарегистрировано в Минюсте России 31.12.2013 № 30961). URL: http://www. consultant.ru/document/cons_doc_LAW_157929/ (дата обращения: 15.01.2018).

5. Инструкция о порядке ведения работ по ликвидации и консервации опасных производственных объектов, связанных с пользованием недрами. РД 07-291-99. Утверждена Постановлением Госгортехнадзора России от 02.06.1999 № 33. URL: http://files.stroyinf.ru/Data1/7/7996/ (дата обращения: 15.01.2018). 
6. Правила безопасности при разработке угольных месторождений открытым способом. ПБ 05-619-03. М., 2004.

7. Инструкция по безопасному ведению горных работ и затопленных выработок. М., 1996.

8. Методическое руководство о порядке выделения провалоопасных зон и выбора комплекса технических мероприятий по выявлению и ликвидации пустот при ликвидации шахт. М.: ИПКОН РАН, 1999.

9. Руководство по проведению мониторинга подземных вод и прогнозу изменения гидрогеологических условий при затоплении ликвидированных шахт Кузбасса. Кемерово: Кузбассвузиздат, 2008.

10. Отчет о научно-исследовательской работе «Разработка комплекса мероприятий по управлению гидрогеологической ситуацией в техногенных горизонтах и на поверхности горных отводов ликвидируемых шахт Прокопьевско-Киселевского угольного района с учетом влияния гидравлически связанных действующих горных предприятий (І этап)», ООО «СИГИ». Прокопьевск, 2017.

ECOLOGY

UDC 556.36622.85:65.016.6:622.33.012.2 ๔ A.I. Bykadorov, A.V. Chernukha, S.V. Svirko, 2018

ISSN 0041-5790 (Print) • ISSN 2412-8333 (Online) • Ugol' - Russian Coal Journal, 2018, № 2, pp. 88-94

Title

ASPECTS OF LIQUIDATION OF MINES OF THE PROKOPYEVSKO-KISELEVSKY COAL DEPOSIT

DOI: http://dx.doi.org/10.18796/0041-5790-2018-2-88-94

\section{Authors}

Bykadorov A.I. ${ }^{1}$, Chernukha A.V. ${ }^{2}$, Svirko S.V. ${ }^{1}$

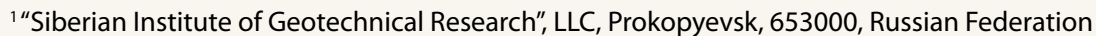

${ }^{2}$ Federal State Budgetary Institution on Reorganization and Liquidation of Non-efficient Mines ("GURSH" FSBI), Moscow, 119019, Russian Federation

\section{Authors' Information}

Bykadorov A.I., PhD (Engineering), General Director,

e-mail: priem_sigi@mail.ru

Chernukha A.V., Deputy Head of Department of Mine Surveying, Geology and Protection of Nature, e-mail: chav @gursh.ru

Svirko S.V., Head of the Laboratory for the Protection of Engineering and Natural Objects, e-mail: svirko@ngs.ru

\section{Abstract}

The technogenic hydrogeological complex including operating, canned and liquidated coal mining enterprises in the cities of Prokopyevsk and Kiselevsk of the Kemerovo region of the Russian Federation is considered. The probable negative hydrogeological, gas-dynamic and geomechanical consequences associated with the liquidation and flooding of the mines of the Prokopyevsko-Kiselevsky coal region are determined. The analysis of the current hydrogeological situation is performed taking into account the prospects for the development of open mining.

Figures:

Fig. Prokopyevsko-Kiselyovskoye coal deposit mine-takes layout

\section{Keywords}

Technogenic complex of hydraulically connected mines, Mark of hydraulic connection, Level of mine flooding, Drainage complex, Pumping out, Forecast of hydrogeological situation development, Surface flooding, Geomechanical processes and phenomena, Hydromonitoring.

\section{References}

1. Pravila ohrany sooruzheniy i prirodnyh obektov ot vrednogo vliyaniya podzemnyh gornyh razrabotok na ugolnyh mestorozhdeniyah [Regulations for facilities and natural objects protection from harmful impact of coal deposits underground workings]. St-Petersburg, 1998.

2. Federalnyy zakon ot 20.06.1996 N81-FZ(red. ot 03.07.2016) "Ogosudarstvennom regulirovanii $v$ oblasti dobychi $i$ ispolzovaniya uglya ob osobennostyah sotsialnoy zashchity rabotnikov organizatsiy ugolnoy promyshlennosti" [Federal law No. 81-FZ, dated 20.06.1996 (revision dated 03.07.2016) "On state regulation of coal mining and coal utilization and the particularities of social security for the employees of coal enterprises"]. Available at: http://www. consultant.ru/document/cons_doc_LAW_10849/ (accessed 15.01.2018). 3. Federalnyy zakon ot 21.07.1997 N 116-FZ (red. ot 07.03.2017) "O promyshlennoy bezopasnosti opasnyh proizvodstvennyh obektov" (s izmeneniyami i dopolneniyami vstupivshih v silu s 25.03.2017) [Federal law No. 116-FZ, dated 21.07.1997 (revision dated 07.03.2017) “On industrial safety of hazardous production facilities" (revised and updated, effective since 25.03.2017)].
Available at: http://www.consultant.ru/document/cons doc LAW 15234/ (accessed 15.01.2018).

4. Prikaz Rostekhnadzora ot 19.11.2013 N 550 (red. ot 08.08.2017) "Ob utverzhdenii Federalnyh norm i pravil v oblasti promyshlennoy bezopasnosti "Pravila bezopasnosti v ugolnyh shahtah" (Zaregistrirovano v Minyuste Rossii 31.12.2013 N 30961) [Rostehnadzor regulation No. 550 dated 19.11.2013 (revision dated 08.08.2017) "On adoption of the Federal industrial safety standards and regulations "Safety regulations in coal mines" (registered by the Ministry of Justice of the Russian Federation on 31.12.2013, No. 30961)]. Available at:http://www.consultant.ru/document/cons_doc_LAW_157929/ (accessed 15.01.2018).

5. Instruktsiya o poryadke vedeniya rabot po likvidatsii i konservatsii opasnyh proizvodstvennyh obektov svyazannyh s pol'zovaniem nedrami RD 07-29199. Utverzhdena Postanovleniem Gosgortekhnadzora Rossii ot 02.06.1999 $N 33$. [Guidelines for abandonment and securing of hazardous production facilities Involving the use of mineral resources. RD 07-291-99. Endorsed by the resolution of Gosgortekhnadzor of Russia, No. 33, dated 02.06.1999]. Available at: http://files.stroyinf.ru/Data1/7/7996/ (accessed 15.01.2018). 6. Pravila bezopasnosti pri razrabotke ugolnyh mestorozhdeniy otkrytym sposobom PB 05-619-03 [Safety regulations for coal open pit mining PB 05-619-03]. Moscow, 2004

7. Instruktsiya po bezopasnomu vedeniyu gornyh rabot i zatoplennyh vyrabotok [Guidelines for safe mining and drowned wastes management] Moscow, 1996

8. Metodicheskoe rukovodstvo o poryadke vydeleniya provaloopasnyh zon i vybora kompleksa tekhnicheskih meropriyatiy po vyyavleniyu i likvidatsii pustot pri likvidatsii shaht [Methodical guidelines for mining damage zones identification and cavities liquidation during mines abandonment]. Moscow, IPKON RAS Publ., 1999

9. Rukovodstvo po provedeniyu monitoringa podzemnyh vod i prognozu izmeneniya gidrogeologicheskih usloviy pri zatoplenii likvidirovannyh shaht Kuzbassa. [Guidelines for underground water monitoring and hydrogeological conditions prediction during abandoned Kuzbass mines flooding]. Kemerovo, Kuzbassvuzizdat Publ., 2008.

10. Otchet o nauchno-issledovatelskoy rabote "Razrabotka kompleksa meropriyatiy po upravleniyu gidrogeologicheskoy situatsiey v tekhnogennyh gorizontah inapoverhnostigorny hotvodov likvidiruemyh shaht Prokopevsko-Kiselevskogo ugolnogo rayona s uchetom vliyaniya gidravlicheski svyazanny deystvuyushchih gornyh predpriyatiy (I etap)" [Report on scientific and research activity "Development of action plan for technogenic horizons and liquidated mines allotment surfaces hydrogeological situation management in ProkopyevskoKiselyovsky coal region with account for hydraulically related active mining enterprises (1 stage)"]. Prokopyevsk, "SIGI", LLC, 2017. 


\title{
СУЭК представила на ФЭС доклад \\ о достижениях в области экологии
}

\author{
на предприятиях логистики
}

Заместитель генерального директора СУЭК - директор по логистике Денис Илатовский представил в декабре 2017 г. на заседании Федерального экологического совета, прошедшем в рамках выставки «Экотех», ключевые экологические решения, которые применяются на предприятиях логистики $\mathrm{AO}$ «Сибирская угольная энергетическая компания» (СУЭК).

В целом в рамках года экологии СУЭК подписаны 10 соглашений с Минприроды Российской Федерации на общую сумму более 6 млрд руб.

Денис Илатовский рассказал, что компания совместно с Ассоциацией морских портов и профильными проектными институтами России провела научно-технический обзор мировых практик в области защиты от пыления при перевалке угля в морских портах и сформировала перечень наилучших технологий. Большинство из них уже реализуется на терминале «Дальтрансуголь» в Хабаровском крае, в Мурманском морском торговом порту (ММТП) и в «СК «Малый порт».

Так, в АО «Дальтрансуголь» с 2013 г. общий объем выбросов вредных веществ снижен в 4,85 раза благодаря реализации комплекса природоохранных мер. Дополнительно в 2017 г. в здании вагоноопрокидывателя проведена модернизация системы пылеподавления DUSTEX: при выгрузке угля система автоматически генерирует мелкодисперсный туман высокой плотности. В общей сложности на мероприятия по улучшению экологии в Дальтрансугле в 2017 г. направлено около 400 млн руб.

В ближайших планах - проектирование ветрозащитных экранов, внедрение системы экологического менеджмента ISO 14001-2016 и выбор наиболее эффективных средств для закрепления пылящих поверхностей с помощью добавок, связывающих пыль.

Особенное место в экологической программе СУЭК отводится ММТП, который является передовой площадкой по внедрению комплекса природоохранных мероприятий. Денис Илатовский подчеркнул, что с 2012 по 2017 г. вложения в экологические программы ММТП возросли в 22 раза, в 2017 г. затраты на природоохранные мероприятия составляют 785 млн руб., а до 2020 г. планируется потратить еще 2,2 млрд руб.

Сегодня производственная территория порта оборудована 8-ю стационарными пушками орошения с радиусом действия 110 м и тремя мобильными, всего по проекту предусмотрено 15 систем орошения. Все туманообразующие пушки оборудованы «зимними пакетами» и работают круглогодично, что позволяет уменьшить пылеобразование на 49\%. «Для сокращения выбросов полностью был переработан весь технологический процесс работы порта, произведеназамена оборудования», - подчеркнул Денис Илатовский.

Еще один масштабный проект - снижение выбросов в атмосферный воздух путем закрытия территории складов угля уникальными 6-метровыми защитными стенками. В общей сложности будет установлено 1426 секций.

По итогам 2017 года суммарные выбросы вредных веществ в атмосферу в порту будут в 2 раза ниже, чем в 2010 г.

Денис Илатовский отметил, что Мурманский порт первым среди портов внедряет систему автоматизированного контроля выбросов в атмосферный воздух на основе международной методики с последующей реализацией проекта по экологической диспетчеризации.

Напомним также, что в рамках заседания ФЭС на выставке «Экотех» СУЭК была отмечена наградой Минприроды Российской Федерации за активную экологическую политику.

Наша справка.

AO «СУЭК» - одна из ведущих угледобывающих компаний мира, крупнейший в России производитель угля, крупнейший поставщик на внутренний рыноки на экспорт. Добывающие, перерабатывающие, транспортные и сервисные предприятия СУЭК расположены в восьми регионах России. На предприятиях СУЭК работают более 33500 человек. Основной акционер - Андрей Мельниченко. 


\title{
Обоснование горнотехнической рекультивации карьеров по добыче нерудных материалов для производства щебня
}

\author{
DOI: http://dx.doi.org/10.18796/0041-5790-2018-2-96-99
}

\author{
ЗЕНЬКОВ Игорь Владимирович \\ Доктор техн. наук, Заслуженный эколог $Р Ф$, \\ Институт вычислительных технологий СО РАН, \\ профессор ФГАОУ ВО «СИбирский федеральный \\ университет", \\ 660041, г. Красноярск, Россия \\ e-mail:zenkoviv@mail.ru
}

\section{БАРАДУЛИН Илья Михайлович \\ Аспирант \\ ФГАОУ ВО «Сибирский федеральный университет», 660041 , г. Красноярск, Россия}

В статье представлены результаты моделирования горнотехнического этапа рекультивации нерабочих бортов отработанных щебеночных карьеров. Установлена оптимальная форма карьерной выемки сучетом географической ориентации нерабочих бортов карьера, влияющая на плотность деревьев и темпы годового прироста. Рассчитан экологический и экономический эффект в результате использования разработанного подхода к проведению горнотехнического этапа рекультивации в отработанных щебеночных карьерах. Ключевые слова: открытые горные работы, щебеночные карьеры, рекультивация нарушенныхземель, техногенная почвенная смесь, лесная экосистема, продуктивность почвенного слоя.

\section{ВВЕДЕНИЕ}

На протяжении всей истории человеческое общество добывает и перерабатывает нерудные материалы для своих нужд. На территории Сибири нерудные материалы добывают в многочисленных так называемых щебеночных карьерах. Особенностью добычи нерудных материалов является появление горнопромышленных ландшафтов в виде остаточных карьерных выемок. В связи с этим всегда возникают вопросы в первую очередь касающиеся восстановления экологического баланса на нарушенных территориях. Решению таких вопросов в нашей стране и за рубежом в последние годы уделяется большое внимание. Оценке восстановления экологии на территориях с объектами горнодобывающей промышленности, решению экологических проблем посвящено множество работ [1, $2,3,4,5,6,7,8,9,10,11,12,13,14]$. Но, несмотря на большой объем научных работ, по-прежнему не освещены вопросы, касающиеся проведения горнотехнического этапа рекультивации в отработанных щебеночных карьерах с целью улучшения показателей растительных экосистем, формирующихся в них в условиях самовосстановления.

\section{РЕШЕНИЕ ПРОБЛЕМЫ}

В ходе горнотехнической рекультивации основными этапами ее проведения являются: формирование продуктивной смеси из почвенных слоев, содержащих гумус; нанесение ее на межуступные площадки нерабочих бортов карьеров. При этом должны быть подготовлены условия для ускоренного появления на территории горнопромышленного ландшафта растительной экосистемы и дальнейшего ее развития экологически приемлемыми темпами.

В разработанной эколого-математической модели предусматривается расчет площади межуступных площадок, поскольку, именно этот показатель в увязке с мощностью техногенной смеси, наносимой не эти площадки, определяет объем работ по горнотехнической рекультивации. Кроме того, исходя из площади межуступных площадок и мощности слоя продуктивной смеси на них определяют прогнозные показатели травянистой или лесной растительности, которая будет находиться на этих площадках в результате ее самовосстановления: продуктивность покрова, плотность деревьев, годовые темпы прироста их стволовой части.

Для того чтобы установить форму карьерной выемки, обеспечивающей наилучшие экологические показатели, необходимо провести сравнительный анализ возможных вариантов постановки нерабочих бортов карьера в стационарное положение, используя результаты исследования разработанной модели. Классическую компоновку нерабочих бортов отработанного щебеночного карьера в форме квадрата представим на рис. 1, $a$.

В моделировании приняты следующие условия: форма карьера в плане - квадрат размером 500×500 м; глубина карьера - 50 м; угол откоса уступов 70; высота всех уступов кроме нижнего - 7 м; высота нижнего уступа - 8 м; ширина межуступных площадок одинаковая для всех бортов и составляет 6 м. Площади элементов архитектуры горнопромышленного ландшафта: общая площадь горизонтальных проекций откосов уступов составляет 41542 м²; общая площадь межуступных площадок составляет

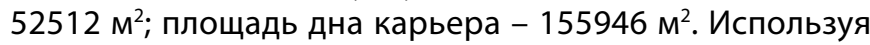
результаты ранее проведенных исследований $[1,2,3,4]$, определим прогнозное количество деревьев в этом карьере и сделаем допущение, что самовосстановление лесной экосистемы будет происходить на межуступных площадках. Количество деревьев, по нашей оценке, составит 917 ед. Как показывает практика, на дне карьеров находятся многочисленные небольшие по площади и неглубокие техногенные водоемы в складках микрорельефа. Этот вид горнопромышленного ландшафта переходит очень быстро в болотистую местность, которая заселяется влаголюбивым тальником. Возможно, здесь будут се- 
литься все представители смешанного леса, но поскольку именно на дне карьера будут собираться дождевые и талые воды, то наш прогноз по лесной экосистеме - количество деревьев на уровне 900-950 ед.

Рассмотрим вариант постановки нерабочих бортов карьера в нерабочее положение, представленный на рис. 1, б. Для расчетов экологических показателей в этом карьере примем следующие технологические условия, прямо оказывающие влияние на плотность и прирост деревьев в лесной экосистеме, которая будет сформирована при ее самовосстановлении. Основные геометрические параметры этого карьера (размеры в плане, глубина) примем по аналогии с карьером, представленном на рис. 1, а. Главным отличием этого карьера от предыдущего являются уменьшенные в десятки раз размеры дна карьера. Размер дна карьера 50×50 м примем из расчета создаваемой емкости в придонной части для сбора в ней талых и дождевых вод объемом $20000 \mathrm{~m}^{3}$.

Рассмотрим архитектуру горнопромышленного ландшафта карьера с расположением емкости для приема природной воды в его центре. В этом случае площади горизонтальных проекций нерабочих бортов равны между собой. Для конструкции нерабочих бортов этого карьера ширина всех межуступных площадок определится размером 34,5 м.

На следующем этапе экологической оптимизации проведем трансформацию площади горизонтальных проекций нерабочих бортов карьера. Для этого сместим дно карьера по двум направлениям: диагональной оси симметрии карьера в угол; горизонтальной оси симметрии в сторону нерабочего борта (рис. 2).

В первом случае в архитектуре горнопромышленного ландшафта щебеночного карьера появляются два узких (западный и северный) и два широких нерабочих борта (восточный и южный), по-разному географически ориентированных.

Западный и северный борта отстраивают из условия ширины межуступных площадок 6 м. Ширина всех площадок на двух других бортах - 63,1 м. Площади площадок для восточного и южного бортов рассчитывают с учетом углов $\gamma$, $\beta$. Во втором случае в архитектуре горнопромышленного ландшафта щебеночного карьера появляются один узкийзападный и один широкий борт - восточный, а также два борта - северный и южный с одинаковой площадью и размером между узким и широким бортами. Западный борт отстраивают из условия ширины межуступных площадок 6 м. Ширину площадок для восточного борта определяют на уровне 63,1 м, а для северного и южного - на уровне 34,5 м. Площади площадок для всех бортов определяют с учетом углов $\omega_{C^{\prime}} \beta_{C^{\prime}} \theta_{C^{\prime}} \gamma_{c^{\prime}}$.

На предпоследнем этапе, используя известные формулы для определения объемных фигур - прямоугольников, поскольку любой слой продуктивной смеси, нанесенной на межуступные площадки, имеет три измерения - рассчитывают объем работ по нанесению техногенной смеси в ходе производства работ по горнотехнической рекультивации. На последнем этапе, исходя из задаваемой мощности слоя продуктивной смеси и географической ориентации нерабочих бортов, определяют прогнозное количество деревьев в лесной экосистеме, формируемой при ее самовосстановлении на межуступных площадках щебеночного карьера. Содержательная часть разработанной модели показывает, что количество принципиально различающихся ва- $a$

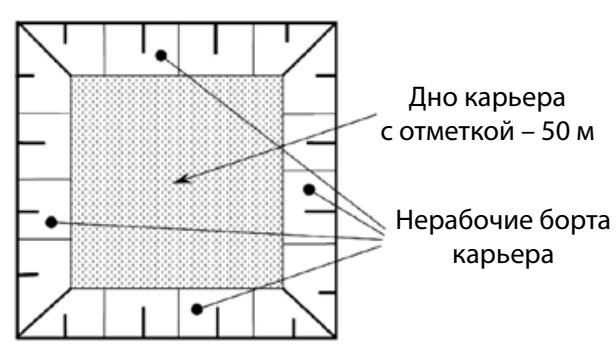

6

Нерабочие борта

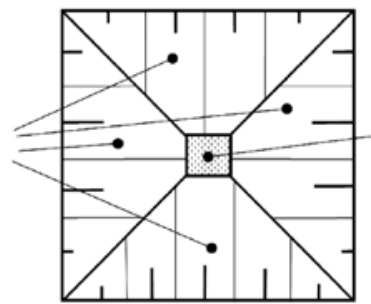

Дно карьера

Рис. 1. План отработанного щебеночного карьера: а - классическая компоновка нерабочих бортов; б - суменьшением площади дна и расширением межуступных плошадок

Fig. 1. Depleted ballast quarry layout: $a$ - conventional nonmining flanks arrangement; $b$ - reduced bottom area and interbench decks extension

$a$

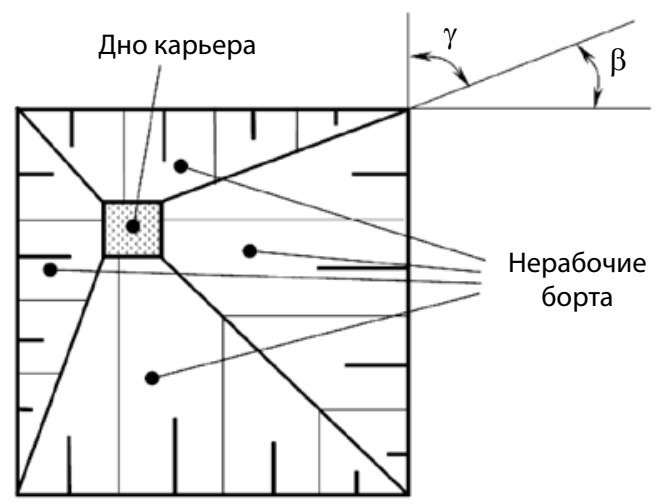

6

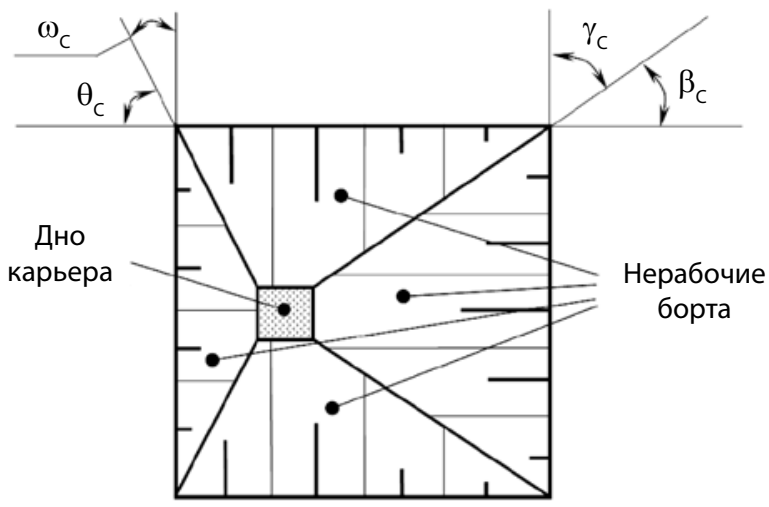

Рис. 2. План отработанного щебеночного карьера со смещением его дна: $а$ - по диагональной оси симметрии; б - по горизонтальной оси симметрии

Fig. 2. Layout of depleted ballast quarry with bottom shifting: $a$-along diagonal center line; $b$-along horizontal center line

риантов конструктивных решений по оформлению нерабочих бортов карьеров, к тому же с различной географической ориентацией, может быть не более девяти. Вместе с тем это количество увеличивается в десятки раз при изменении конструкций межуступных площадок, а также в слу- 


\section{Прогнозные показатели количества взрослых деревьев в щебеночных карьерах} с двумя вариантами расположения дна

Элемент нерабочего борта карьера
Расположение дна карьера

\begin{tabular}{|c|c|}
\hline \multicolumn{2}{|c|}{ Расположение дна карьера } \\
\hline В центре & Смещение в северо-западный угол \\
\hline 4219 & 6751 \\
\hline 3626 & 5833 \\
\hline 4918 & 7763 \\
\hline 7271 & 11563 \\
\hline 6787 & 10943 \\
\hline 7688 & 12090 \\
\hline
\end{tabular}

Межуступные горизонтальные площадки без нанесения продуктивной смеси Межуступные площадки без нанесения продуктивной смеси с уклоном 3-50 в сторону выработанного пространства

Межуступные площадки без нанесения продуктивной смеси с уклоном 3-50 в сторону нерабочего борта

Межуступные горизонтальные площадки с нанесением продуктивной смеси Межуступные площадки с нанесением продуктивной смеси с уклоном 3-50 в сторону выработанного пространства

Межуступные площадки с нанесением продуктивной смеси с уклоном 3-50 в сторону нерабочего борта

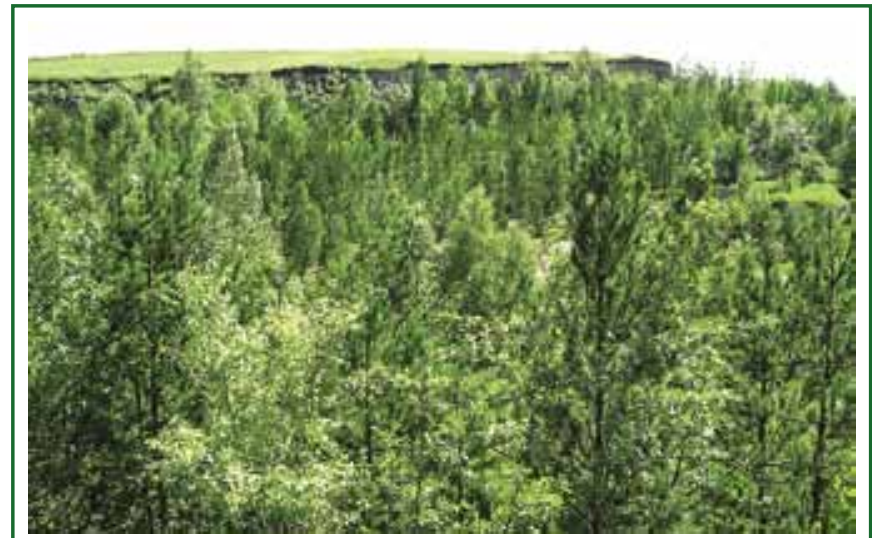

Рис. 3. Лесная экосистема, принятая за эталон при ее самовосстановлении в щебеночных карьерах

Fig. 3. Forestry eco-system as reference model of regeneration in the ballast quarries

бот по горнотехническому этапу рекультивации в размере 980 тыс. руб., проведенной в одном карьере.

\section{ЗАКЛЮЧЕНИЕ}

Итак, на основе комплексного анализа результатов полевых экспедиций, дистанционного горно-экологического мониторинга, результатов моделирования установлены закономерности формирования локальных растительных экосистем в отработанных щебеночных карьерах с разнящимисяпоказателями, которые положены в основу экологической оптимизации геометрической формы карьерной выработки. Установленные экологически оптимальные параметры карьеров должны приниматься во внимание при формировании технического задания на проектирование открытых горных работ на месторождениях по добыче нерудных материалов.

\section{Список литературы}

1. Zenkov I.V., Yuronen Yu.P., Nefedov B.N., Baradulin I.M. Remote sensing in estimation of forest ecosystem generation at crushed stone quarries in Siberia // Eurasian mining. 2016. Vol.1. Pp. 50-54.

2. Зеньков И.В., Барадулин И.М. Обоснование конечной формы щебеночных карьеров Сибири в целях лесотехнической рекультивации // Горный журнал. 2016. № 3. С. 85-88.

3. Зеньков И.В., Барадулин И.М. Результаты исследования условий появления и формирования растительного покрова в отработанных щебеночных карьерах //Уголь. 2017. № 12 C. 69-71. URL: http://www.ugolinfo.ru/Free/122017.pdf (дата обращения: 15.01.2018). 
4. Зеньков И.В., Барадулин И.М. Исследование условий формирования ихарактеристиклесныхэкосистем в отработанных щебеночных карьерах в Красноярском крае //Уголь. 2018. №1. C. 81-83. doi: 10.18796/0041-5790-2018-1-81-83.

5. Ульрих Д.В., Денисов С.Е., Тимофеева С.С. Оценка влияния горнодобывающих и перерабатывающих предприятий на экологическую обстановку в Челябинской области // Горный журнал. 2015. № 5, С. 94-99.

6.Семина И.С., Андроханов В.А.О рекультивации нарушенных земель на разрезах Кузбасса // Горный информационноаналитический бюллетень. 2014. № 12, С. 307-314.

7. Таразанов И.Г. Итоги работы угольной промышленности России за январь-сентябрь 2017 года // Уголь. 2018. № 1. С. 18-32. doi: 10.18796/0041-5790-2018-1-18-32

8. Яновский А.Б. Основные тенденции и перспективы развития угольной промышленности России //Уголь. 2017. № 8. C.10-14. doi: 10.18796/0041-5790-2017-8-10-14. URL: http://www.ugolinfo.ru/Free/082017.pdf (дата обращения: 15.01.2018).

9. Abdullah M.M., Feagin R.A., Musawi L., Whisenant S., Popescu S. The use of remote sensing to develop a site history for restoration planning in an arid landscape // Restoration Ecology. 2016. Vol. 24(1). Pp. 91-99.

10. Zweig C.L., Newman S. Using landscape context to map invasive species with mediumresolution satellite imagery // Restoration Ecology. 2015. Vol. 23(5). Pp. 524-530.

11. Borrelle S.B., Buxton R.T., Jones H.P., Towns D.R. A GISbased decision-making approach for prioritizing seabird management following predator eradication // Restoration Ecology. 2015. Vol. 23(5). P. 580-587.

12. Strunk S., Houben B., Krudewig W. Controlling the Rhenish opencast mines during the transition of the energy industry // World of Mining - Surface \& Underground. 2016. Vol. 68(5). Pp. 289-300.

13. Shoo L.P., Scarth P., Schmidt S., Wilson K.A. Reclaiming Degraded Rainforest: A Spatial Evaluation of Gains and Losses in Subtropical Eastern Australia to Inform Future Investment in Restoration// Restoration Ecology. 2013. Vol. 21(4). Pp.481-489.

14. Sena K., Barton C., Hall S., Angel P., Agouridis C., Warner $R$. Influence of spoil type on afforestation success and natural vegetative recolonization on a surface coal mine in Appalachia, United States//Restoration Ecology. 2015.Vol. 23(2).Pp. 131-138.

UDC 622.882:622.271.3 @ I.V. Zenkov, I.M. Baradulin, 2018

ECOLOGY

ISSN 0041-5790 (Print) • ISSN 2412-8333 (Online) • Ugol' - Russian Coal Journal, 2018, № 2, pp. $96-99$

\section{Title}

SUBSTANTIATION OF MINING-ENGINEERING RECLAMATION OF NONMETALLIC MATERIALS QUARRIES FOR BALLAST PRODUCTION

DOI: http://dx.doi.org/10.18796/0041-5790-2018-2-96-99

\section{Authors}

Zenkov I.V., ${ }^{1,}$, Baradulin I.M. ${ }^{2}$

'Special Design and Technological Bureau "Nauka" of Institute computational technology

of Siberian Branch Russian Academy of Sciences (SDTB “Nauka” ICT SB RAS), Krasnoyarsk, 660049, Russian Federation

${ }^{2}$ Federal State-Autonomous Educational Institution of Higher Professional Education (FSAEI HPE) Siberian Federal University,

Krasnoyarsk, 660041, Russian Federation

\section{Authors' Information}

Zenkov I.V., Doctor of Engineering Sciences, Merited Ecologist of the Russian Federation, Professor, e-mail: zenkoviv@mail.ru

Baradulin I.M., Postgraduate

\section{Abstract}

The paper presents the results of depleted ballast quarries non-mining flanks mining-engineering reclamation modelling. The optimal quarrying geometry is established with account for non-mining quarry flanks geographic orientation, affecting trees density and annual crop rates. Environmental and economic impact of the proposed approach to depleted ballast quarries mining and engineering reclamation is evaluated.

Figures:

Fig. 1. Depleted ballast quarry layout: $a$ - conventional non-mining flanks arrangement; $b$ - reduced bottom area and inter-bench decks extension

Fig. 2. Layout of depleted ballast quarry with bottom shifting: a - along diagonal center line; $b$-along horizontal center line

Fig. 3. Forestry eco-system as reference model of regeneration in the ballast quarries

\section{Keywords}

Surface mining, Ballast quarries, Disturbed lands reclamation, Engineered soil mix, Forestry eco-system, Soil layer fertility.

\section{References}

1. Zenkov I.V., Yuronen Yu.P., Nefedov B.N. \& Baradulin I.M. Remote sensing in estimation of forest ecosystem generation at crushed stone quarries in Siberia. Eurasian mining, 2016, Vol. 1, pp. 50-54.

2. Zenkov I.V. \& Baradulin I.M. Obosnovanie konechnoy formy shchebenochnykh kar'erov Sibiri v tselyakh lesotekhnicheskoy rekul'tivatsii [Ultimate pit limit substantiation for the purpose of forestry reclamation of lands at ballast quarries in Siberia]. Gornyi Zhurnal - Mining Journal, 2016, No. 3, pp. 85-88.

3. Zenkov I.V. \& Baradulin I.M. Rezul'taty issledovaniya usloviy poyavleniya i formirovaniya rastitel'nogo pokrova $v$ otrabotannykh shchebenochnykh kar'erakh [Study results of vegetation emergence and formation in depleted crushed stone quarries]. Ugol' - Russian Coal Journal, 2017, No. 12, pp. 69-71. Available at: http:// www.ugolinfo.ru/Free/122017.pdf (accessed 15.01.2018).

4. Zenkov I.V. \& Baradulin I.M. Issledovanie usloviy formirovaniya i kharakteristik lesnykh ekosistem $v$ otrabotannykh shchebenochnykh kar'erakh v Krasnoyar- skom krae [Study results of vegetation emergence and formation in depleted crushed stone quarries in Krasnoyarsk Krai]. Ugol' - Russian Coal Journal, 2018, No. 1, pp. 81-83. doi: 10.18796/0041-5790-2018-1-81-83.

5. Ulrikh D.V., Denisov S.E. \& Timofeyeva S.S. Otsenka vliyaniya gornodobyvayushchih i pererabatyvayushchih predpriyatiy na ekologicheskuyu obstanovku v CHelyabinskoy oblasti [Evaluation of mining and processing enterprises impact on environmental situation in Chelyabinsk district]. Gornyy Zhurnal - Mining Journal, 2015, No. 5, pp. 94-99.

6. Semina I.S., Androkhanov V.A. O rekultivatsii narushennyh zemel na razrezah Kuzbassa [On disturbed lands reclamation in Kuzbass open-pit mines]. Gornyy Informatsionno-Analiticheskiy Byulleten' - Mining Information and Analytical Bulletin, 2014, No. 12, pp. 307-314.

7. Tarazanov I.G. Russia's coal industry performance for January - September, 2017. Ugol' - Russian Coal Journal, 2018, No. 1, pp. 18-32. doi: 10.18796/00415790-2018-1-18-32.

8. Yanovsky A.B. Main trends and prospects of the coal industry development in Russia. Ugol' - Russian Coal Journal, 2017, No. 8, pp. 10-14. doi: 10.18796/00415790-2017-8-10-14. Available at: http://www.ugolinfo.ru/Free/082017.pdf (accessed 15.01.2018)

9. Abdullah M.M., Feagin R.A., Musawi L., Whisenant S. \& Popescu S. The use of remote sensing to develop a site history for restoration planning in an arid landscape. Restoration Ecology, 2016, Vol. 24(1). pp. 91-99.

10. Zweig C.L. \& Newman S. Using landscape context to map invasive species with mediumresolution satellite imagery. Restoration Ecology, 2015, Vol. 23(5), pp. 524-530. 11. Borrelle S.B., Buxton R.T., Jones H.P. \& Towns D.R. A GIS-based decision-making approach for prioritizing seabird management following predator eradication. Restoration Ecology, 2015, Vol. 23(5), pp. 580-587.

12. Strunk S., Houben B. \& Krudewig W. Controlling the Rhenish opencast mines during the transition of the energy industry. World of Mining - Surface \& Underground, 2016, Vol. 68(5), pp. 289-300.

13. Shoo L.P., Scarth P., Schmidt S. \& Wilson K.A. Reclaiming Degraded Rainforest: A Spatial Evaluation of Gains and Losses in Subtropical Eastern Australia to Inform Future Investment in Restoration. Restoration Ecology, 2013, Vol. 21(4), pp. 481-489.

14. Sena K., Barton C., Hall S., Angel P., Agouridis C. \& Warner R. Influence of spoil type on afforestation success and natural vegetative recolonization on a surface coal mine in Appalachia, United States. Restoration Ecology, 2015, Vol. 23(2), pp. 131-138. 


\title{
Обоснование горнотехнической рекультивации по созданию культурного ландшафта в карьере по разработке глиежей
}

\author{
DOI: http://dx.doi.org/10.18796/0041-5790-2018-2-100-102
}

\author{
ХАРИОНОВСКИЙ Анатолий Алексеевич \\ Доктор техн. наук, академик АГН, \\ заместитель генерального директора \\ по научной работе \\ ООО «МНИИЭКО ТЭК», \\ 614007, г. Пермь, Россия, \\ e-mail:mniiekotek2009@yandex.ru
}

\section{ФРАНК Елена Яковлевна}

Канд. техн. наук,

заместитель директора Института экономики

и менеджмента,

ФГБОУВО «Сибирский государственный

индустриальный университет»,

654007 , г. Новокузнецк, Россия

В статье представлены компоновочная схема культурного ландшафта в карьере по разработке глиежей после окончания горных работ в нем, а также объемы работ по горнотехнической рекультивации. Культурный ландшафт предлагается обустроить путем создания искусственного озера, встроенного в русло реки Рыбная в Красноярском крае, прибрежной площадки с посевом травосмеси и отстройки нерабочего борта карьера, ориентированного на запад и частично на север, на межуступных площадках которого произойдет самовосстановление лесной экосистемы.

Ключевые слова: открытые горные работы, карьеры, культурный ландшафт после рекультивации, искусственный водоем, экологические показатели, техногенная продуктивная смесь, лесные экосистемы.

\section{ВВЕДЕНИЕ}

В Красноярском крае вблизи крупных угольных месторождений находятся небольшие по площади месторождения горелых пород - глиежей. Эти горные породы широко используются в строительстве дорог при отсыпке дорожного полотна под внутрикарьерные автомобильные и железные дороги. Практика разработки карьеров глиежей показывает, что горные работы не ориентированы на экологические цели. Поэтому актуальность разработки новых подходов к проведению горнотехнической рекультивации территории карьеров с целью создания в них культурных ландшафтов не вызывает сомнений.

\section{РЕШЕНИЕ ПРОБЛЕМЫ}

Вопросами экологии широкого спектра в горном деле занимаются специалисты во всех ресурсодобывающих странах. Результаты изучения экологических проблем и их решения в условиях открытых горных работ на месторождениях твердых полезных ископаемых досточно детально изложены в работах $[1,2,3,4,5,6,7,8,9]$. Вместе с тем анализ этих и других работ показывает, что разработки, касающиеся обоснования технологий горнотехнической рекультивации с целью создания культурных ландшафтов в таких карьерах, в специальной литературе практически отсутствуют.

Исследуемый с начала 2000-х годов объект - карьер по разработке глиежей находится на берегу р. Рыбной в Рыбинском районе Красноярского края. Площадь карьера в 2004 г. составляла 0,86 га, а к 2008 г. этот показатель увеличился в 4,9 раза, до 4,25 га. На снимках из космоса, сделанных в 2004 и 2008 гг., просматривается явный бессистемный подход к разработке участка месторождения глиежей. С другой стороны, практика открытых горных работ показывает, что при их производстве, и в особенности на месторождениях общераспространенных полезных ископаемых, можно создать заранее запрограммированную архитектуру горнопромышленного ландшафта, который при необходимости, без существенных дополнительных финансовых затрат, можно трансформировать в культурный.

При выборе направлений рекультивации карьера необходимо учитывать природные и технологические факторы: карьер находится на косогоре; близость реки и возможность формирования проточного озера параллельно с руслом реки; произрастание смешанного леса повсеместно и в шаговой доступности от карьера в северном, западном и южном направлениях (см. рисунок).

Близость смешанного леса, являющегося хорошим источником семенного материала, значительно ускоряет появление лесной экосистемы на межуступных площадках нерабочих бортов карьеров, что доказано в работах $[1,2,3,4,5]$.

В любом проекте на разработку месторождений имеется раздел «Рекультивация нарушенных земель», в который входит план горных работ на момент отработки карьера. Для исследуемого карьера на рисунке показана компоновочная схема культурного ландшафта, сформированного в ходе горнотехнической рекультивации. В восточном и юго-восточном секторах искусственного ландшафта желтым цветом показаны горизонтальные проекции откосов нерабочих уступов высотой 8 м каждый. На территории будущего озера на завершающем этапе гидравлическим экскаватором типа «обратная лопата» производится выемка глиежей на глубину до 6 м. С целью исключения прорыва речной воды в котлован на северном и 


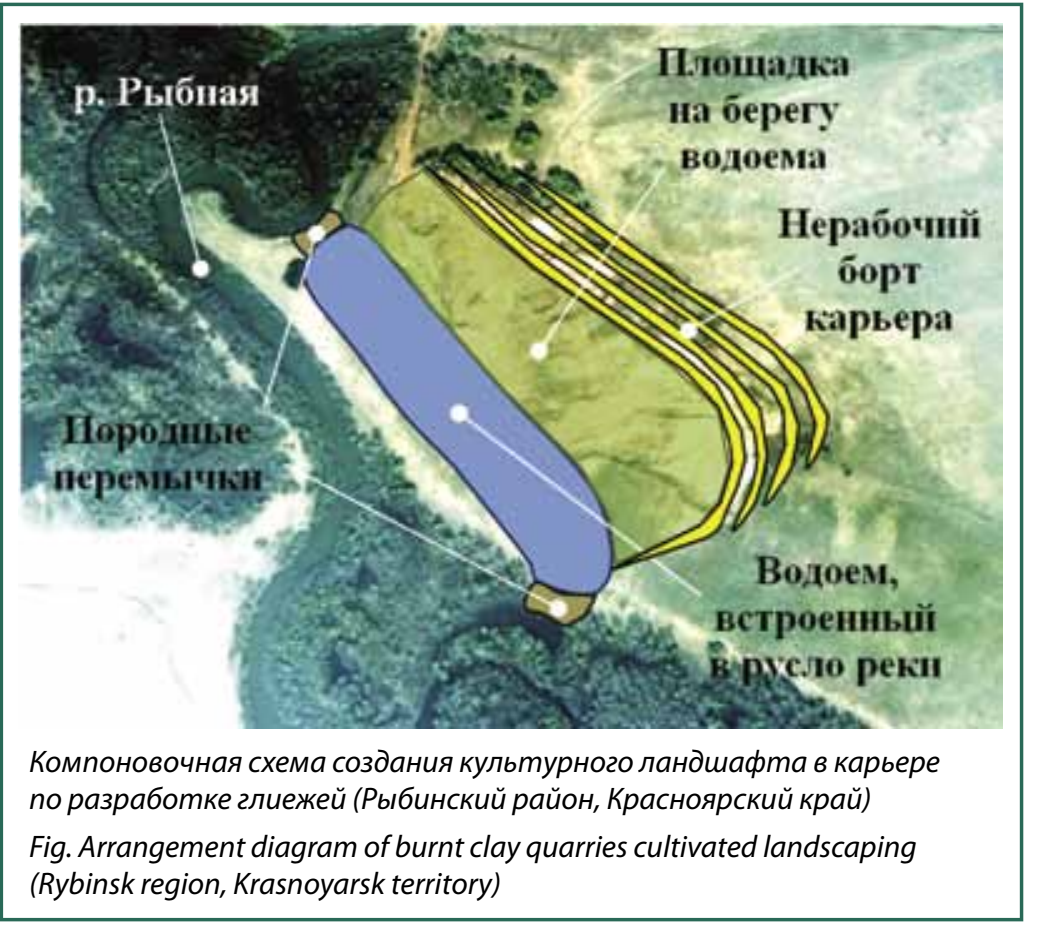

Отметим, что глубинная часть сибирских ректрадиционные места обитания щуки, ельца, хариуса, сороги и др. Учитывая это обстоятельство, с уверенностью можно сказать, что культурный ландшафт будет пользоваться популярностью у любителей летней и зимней рыбалки, проживающих в ближайших населенных пунктах. На горизонтальной площадке, подходящей к озеру, в летнее время можно проводить летние молодежные и студенческие музыкальные форумы и фестивали, экологические школы.

\section{ЗАКЛЮЧЕНИЕ}

Итак, в статье наглядно показана возможность создания многофункционального культурного ландшафта на территории отработанного карьера глиежей. Этому должны способствовать порядок отработки месторождения, а также технологии горнотехнической и биологической рекультивации, способствующие улучшению экологической обстановки в районе производства открытых горных работ.

южном флангах озера оставляются породные перемычки, ширина которых должна быть не менее ширины хода экскаватора и двух берм безопасности слева и справа по ходу экскаватора. Эти перемычки объемом 300 м³ срабатываются экскаватором на заключительном этапе отработки месторождения.

Далее происходит заполнение котлована речной водой. Площадь проточного искусственного озера, встроенного в русло реки, составляет 2,35 га. На восток от него производится грубая и чистовая планировка горизонтальной площадки площадью 3,4 га. На ней впоследствии производят посев смеси трав из мятлика лугового, овсяницы красной, полевицы тонкой, райграса и т.п. Общая площадь культурного ландшафта, включающего озеро, прибрежную площадку и нерабочий борт карьера, составляет 7,3 га. В ходе горнотехнической рекультивации наносят техногенную смесь из рыхлых пород четвертичного возраста на межуступные площадки нерабочего борта карьера и прибрежную площадку. Технологические показатели производства работ для комплектации механизмами этапа горнотехнической рекультивации представлены в таблице.

\section{Технологические показатели горнотехнической рекультивации по обустройству культурного ландшафта в карьере глиежей}

\begin{tabular}{|c|c|}
\hline Показатель & Значение \\
\hline Площадь межуступных площадок в карьере, м² & 12000 \\
\hline $\begin{array}{l}\text { Площадь горизонтальной прибрежной } \\
\text { площадки, } \text { м² }^{2}\end{array}$ & 34000 \\
\hline Мощность наносимой продуктивной смеси, м & 0,4 \\
\hline Объем продуктивной смеси, м³ & 18400 \\
\hline $\begin{array}{l}\text { Объем экскаваторных работ по срабатыванию } \\
\text { породных перемычек, м³ }\end{array}$ & 300 \\
\hline $\begin{array}{l}\text { Прогнозное количество деревьев в лесной } \\
\text { экосистеме (смешанный лес) на межуступных } \\
\text { площадках карьера согласно данным }[1,2,3,4]\end{array}$ & 429 \\
\hline
\end{tabular}

\section{Список литературы}

1. Зеньков И.В., Барадулин И.М. Обоснование конечной формы щебеночных карьеров Сибири в целях лесотехнической рекультивации // Горный журнал. 2016. № 3. C. 85-88.

2. Zenkov I.V., Yuronen Yu.P., Nefedov B.N., Baradulin I.M. Remote sensing in estimation of forest ecosystem generation at crushed stone quarries in Siberia // Eurasian mining. 2016. № 1. Рp. 50-54.

3. Зеньков И.В., Барадулин И.М. Результаты исследования условий появления и формирования растительного покрова в отработанных щебеночных карьерах //Уголь. 2017. № 12 C. 69-71. URL: http://www.ugolinfo.ru/Free/122017.pdf (дата обращения: 15.01.2018).

4. Зеньков И.В., Барадулин И.М. Экологическая оптимизация в технологиях разработки месторождений строительного щебня // Экология и промышленность России. 2015. T.19, № 3. C. 40-44.

5. Naeth M.A., Wilkinson S.R. Establishment of Restoration Trajectories for Upland Tundra Communities on Diamond Mine Wastes in the Canadian Arctic // Restoration Ecology. 2014. Vol. 22(4). Pp. 534-543.

6. Sena K., Barton C., Hall S., Angel P., Agouridis C., Warner R. Influence of spoil type on afforestation success and natural vegetative recolonization on a surface coal mine in Appalachia, United States // Restoration Ecology. 2015. Vol. 23(2). Pp. 131-138.

7. Gilland K.E., McCarthy B.C. Microtopography Influences Early Successional Plant Communities on Experimental Coal Surface Mine Land Reclamation // Restoration Ecology. 2014. Vol. 22(2). Pp. 232-239.

8. Zhang Hao, Zhuang Xueying, Chu L.M. Plant Recruitment in Early Development Stages on Rehabilitated Quarries in Hong Kong // Restoration Ecology. 2013. Vol. 21(2). Pp. 166-173.

9. Ngugil M.R., Neldner V.J., Doley D., Kusy B., Moore D., Richter C. Soil moisture dynamics and restoration of selfsustaining native vegetation ecosystem on an open-cut coal mine // Restoration Ecology. 2015. Vol. 23(5). Pp. 615-624. 
UDC 622.882:622.271.3 @ A.A. Kharionovsky, E.Ya. Frank, 2018

ISSN 0041-5790 (Print) • ISSN 2412-8333 (Online) • Ugol' - Russian Coal Journal, 2018, № 2, pp. 100-102

Title

SUBSTANTIATION OF MINING-ENGINEERING RECLAMATION FOR BURNT CLAY MINES CULTIVATED LANDSCAPING

DOI: http://dx.doi.org/10.18796/0041-5790-2018-2-100-102

\section{Authors}

Kharionovsky A.A. ${ }^{1}$, Frank E.Ya. ${ }^{2}$

1 "MNIIEKO TEK", LLC, Perm, 614007, Russian Federation

${ }^{2}$ Institute of Economics and Management at FSBEl of Higher Education "Siberian State Industrial University", Novokuznetsk, 654007, Russian Federation Autors Information Kharionovsky A.A., Doctor of Engineering Sciences, Deputy General Director, Academy Fellow of the Academy of Mining Sciences, e-mail: mniiekotek2009@yandex.ru Frank E.Ya., PhD (Engineering), Deputy Director

\section{Abstract}

The paper presents arrangement diagram of burnt clay pit cultivated landscape after mining completion, as well as mining and engineering reclamation work scope. It is proposed to cultivate landscape by arrangement of manmade lake, integrated in the Rybnaya river bed, in Krasnoyarsk territory, and nearshore area with grass seeding, west and partially north non-mining quarry flank orientation with forestry eco-system self-regeneration in inter-bench decks.

Figures:

Fig. Arrangement diagram of burnt clay quarries cultivated landscaping (Rybinsk region, Krasnoyarsk territory)

Keywords

Surface mining, Quarries, Cultivated landscape after reclamation, Manmade water body, Environmental indicators, Engineered fertile mix, Forestry eco-systems.

\section{References}

1. Zenkov I.V. \& Baradulin I.M. Obosnovanie konechnoy formy shchebenochnykh kar'erov Sibiri v tselyakh lesotekhnicheskoy rekul'tivatsii [Ultimate pit limit substantiation for the purpose of forestry reclamation of lands at ballast quarries in Siberia]. Gornyi Zhurnal - Mining Journal, 2016, No. 3, pp. 85-88.

2.Zenkov I.V.,Yuronen Yu.P., Nefedov B.N. \& Baradulin I.M. Remote sensing in estimation of forest ecosystem generation at crushed stone quarries in Siberia. Eurasian mining, 2016, No. 1, pp. 50-54.
3. Zenkov I.V. \& Baradulin I.M. Rezul'taty issledovaniya usloviy poyavleniya i formirovaniya rastitel'nogo pokrova v otrabotannykh shchebenochnykh kar'erakh [Study results of vegetation emergence and formation in depleted crushed stone quarries]. Ugol'- Russian Coal Journal, 2017, No. 12, pp. 69-71. Available at: http://www. ugolinfo.ru/Free/122017.pdf (accessed 15.01.2018).

4. Zenkov I.V. \& Baradulin I.M. Ekologicheskaya optimizatsiya v tekhnologiyah razrabotki mestorozhdeniy stroitelnogo shchebnya [Construction crushed stone deposits development technologies environmental optimization]. Ekologiya ipromyshlennost Rossii - Environment and Industry of Russia, 2015, Vol. 19(3), pp. 40-44. 5. Naeth M.A. \&Wilkinson S.R. Establishment of Restoration Trajectories for Upland Tundra Communities on Diamond Mine Wastes in the Canadian Arctic. Restoration Ecology, 2014, Vol. 22(4), pp. 534-543.

6. Sena K., Barton C., Hall S., Angel P., Agouridis C. \&Warner R. Influence of spoil type on afforestation success and natural vegetative recolonization on a surface coal mine in Appalachia, United States. Restoration Ecology, 2015, Vol. 23(2), pp. 131-138. 7. Gilland K.E. \& McCarthy B.C. Microtopography Influences Early Successional Plant Communities on Experimental Coal Surface Mine Land Reclamation. Restoration Ecology, 2014, Vol. 22(2), pp. 232-239.

8. Zhang Hao, Zhuang Xueying \& Chu L.M. Plant Recruitment in Early Development Stages on Rehabilitated Quarries in Hong Kong. Restoration Ecology, 2013, Vol. 21(2), pp. 166-173.

9. Ngugil M.R., Neldner V.J., Doley D., Kusy B., Moore D. \& Richter C. Soil moisture dynamics and restoration of self-sustaining native vegetation ecosystem on an open-cut coal mine. Restoration Ecology, 2015, Vol. 23(5), pp. 615-624.

\section{Tozgpabлreu!}

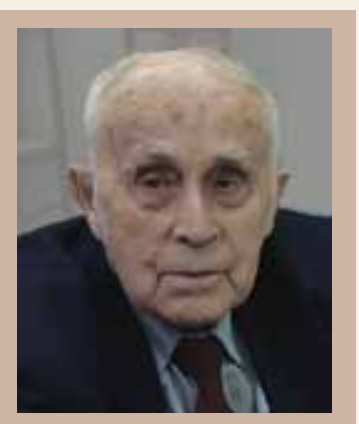

Рифат Хабибулович Гизатулин родился в г. Астрахани. В августе 1941 г., будучи студентом Астраханского РыбВТУЗ(а) был призван в Красную Армию и по окончании краткосрочных курсов радистов направлен в действующую армию. В 1943 г. попал в плен, через два месяца бежал. Был определен в спецлагерь НКВД и осужден на 10 лет лагерей, в апреле 1953 г. освобожден, а в июле 1956 г. полностью реабилитирован.

Трудовую деятельность Рифат Хабибулович начал на шахтах комбината «Воркутуголь», пройдя путь от рядового работника планового отдела до заместителя управляющего трестом «Западуголь». В 1961 г. защитил диплом горного инженера-экономиста, в 1970 г. был приглашен на работу в один из НИИ в г. Москву, а в 1973 г. возглавил отдел разработки подсистем управления финансовой деятельностью предприятий во вновь образованном институте «ВНИИУуголь».

\section{(к 95-летию со дня рождения)}

В 1976 г. Рифат Хабибулович окончил заочную аспирантуру и защитил кандидатскую диссертацию, активно участвовал в реструктуризации угольной промышленности. В феврале 2005 г., в возрасте 82 лет, уволился на пенсию в связи с полученной травмой. Его общий непрерывный трудовой стаж в угольной промышленности составил 62 года.

Рифат Хабибулович Гизатулин был участником парада на Красной Площади 9 мая 2005 г. в честь 60-летия Победы в Великой Отечественной войне. Награжден орденом «Отечественной войны», 18-ю медалями, бронзовой медалью ВДНХ СССР, знаком «Шахтерская слава» всех трех степеней.

Рифат Хабибулович является членом Русского географического общества, членом Международного Союза Славянских туристов, кандидатом в мастера спорта по шахматам, автором сборника стихов и ряда книг.

\section{Коллеги и друзья, ветераны Печорского угольного бассейна, члены РОО «Землячество Коми» в г. Москве, редакционная коллегия и редакция журнала «Уголь» горячо




\section{ФоНД «СУЭК - РЕГИОНАМ» ИнВестирУет \\ В развитие детско-юношеской спортивной школы \\ города Бородино}

Фонд «СУЭК - РЕГИОНАМ» инвестирует в развитие детско-юношеской спортивной школы (ДЮСШ) г. Бородино Красноярского края. На средства угольщиков, в частности, идет оборудование крупнейшего объекта ДЮСШ - комплекса по зимним видам спорта.

Построенный в 2015 г. также при содействии СУЭК комплекс по зимним видам спорта является одним из основных тренировочных центров красноярских лыжников и биатлонистов в рамках подготовки к «XXIX Всемирной зимней универсиаде-2019». В состав сборной края включены и многие воспитанники бородинской ДЮСШ.

«Благодаря работе комплекса по зимним видам спорта наш город фактически стал краевой кузничей по подготовке спортивного резерва», - подчеркивает глава Бородино Александр Веретенников.

Кроме того, под эгидой Академии биатлона на базе Бородино регулярно проходят соревнования краевого, межрегионального и федерального уровней. По словам Александра Веретенникова, организаторы и участники всегда отмечают уровень спортивной базы, условия и качество подготовки турниров. Большая работа проведена на объекте в минувшем году: финансирование СУЭК позволило обустроить территорию возле ДЮСШ, реконструировать пулеулавливающий вал.

В настоящее время воспитанники ДЮСШ готовятся представлять Красноярский край на Первенстве Сибирского федерального округа, которое пройдет в феврале в Новосибирске. Выступать на этих соревнованиях бородинцы будут в новом спортивном снаряжении, которое получили в подарок от Фонда

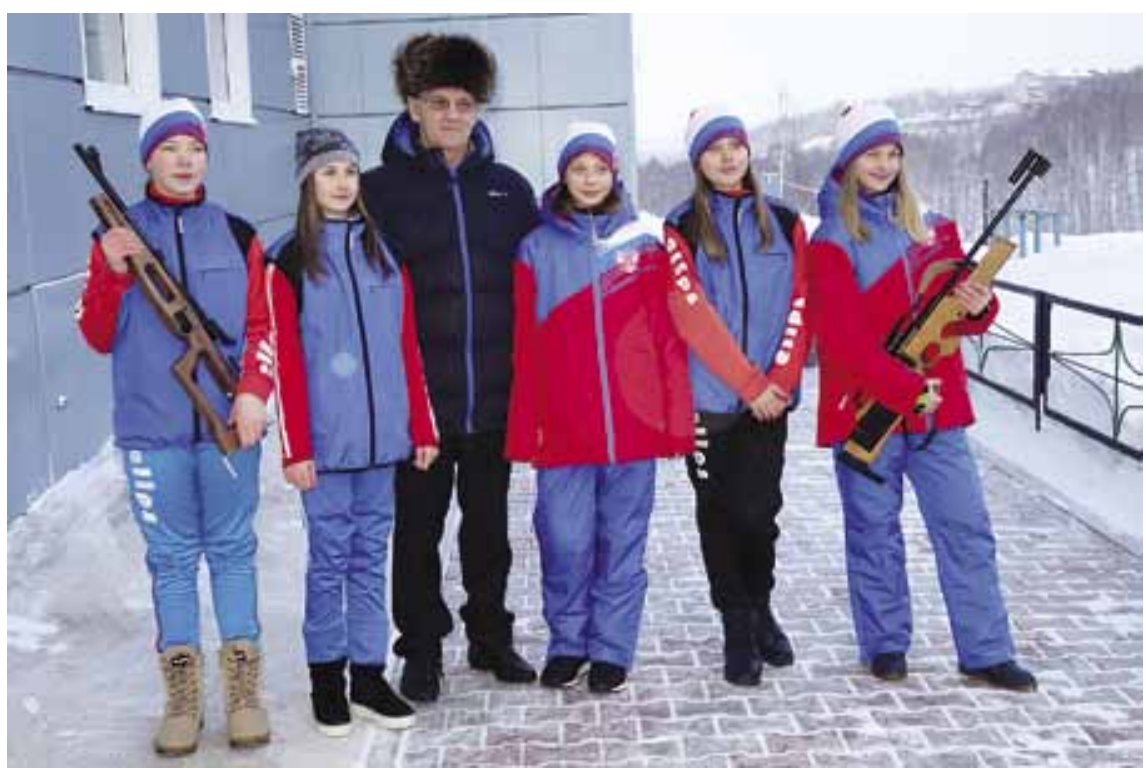

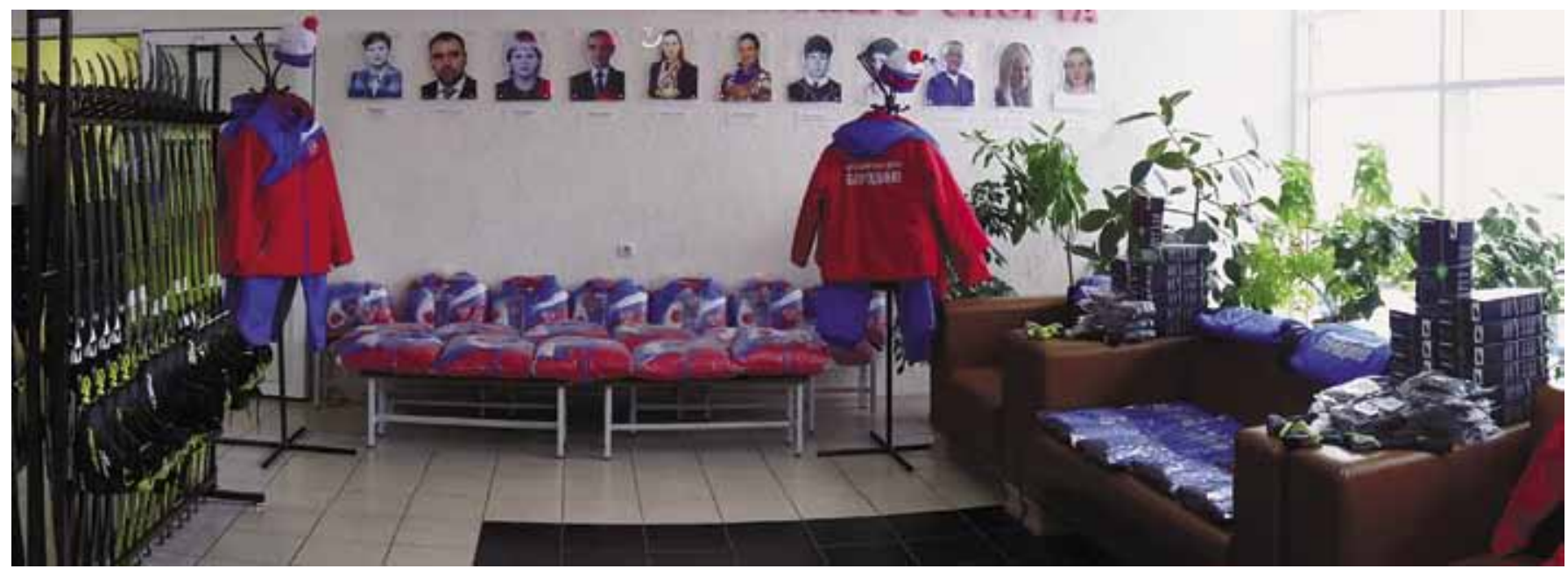




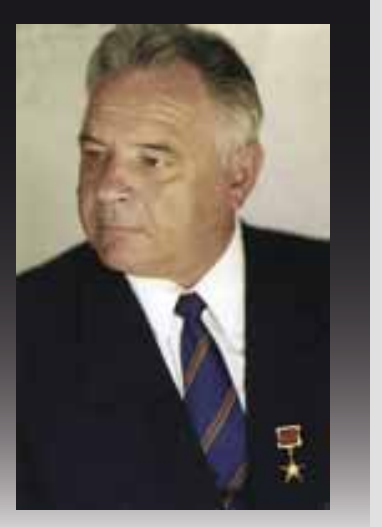

30 декабря 2017 г. на 80-м году ушел из жизни Герой Сочиалистического Труда, Лауреат Государственной премии, Кавалер Ордена Трудового Красного Знамени, Заслуженный шахтер РСФСР, доктор технических наук, профессор, член-корреспондент Российской и Международной инженерных академий, академик Академии горных наук, бывший руководитель компании «Кузбассразрезуголь» Виктор Иванович Кузнецов.

Замечательный, честнейший человек, большой труженик, всю свою жизнь посвятивший угольной отрасли Кузбасса. Более 40 лет Виктор Иванович Кузнецов плодотворно трудился в угольной промышленности. Его трудовая деятельность была полностью связана с освоением месторождений Кузнецкого угольного бассейна и неизменно проходила в одной и той же угледобывающей организации, специализирующейся в области открытых горных работ, именовавшейся в начале трестом «Кемеровоуголь», затем производственным объединением «Кемеровоуголь», затем ОАО «Холдинговая компания «Кузбассразрезуголь».

С именем В.И. Кузнецова связан один из важнейших этапов становления и развития «Кузбассразрезугля». Ему выпало руководить крупнейшим объединением угольных предприятий страны в самый сложный период отечественной экономики, во время реструктуризации угольной отрасли. Он смог вывести концерн из кризиса, сумел сохранить и предприятия объединения, и трудовые коллективы.

Его профессионализм, самоотдача, ответственность, огромная работоспособность, умение вдохновить личным примером вызывали глубокое уважение у всех, кому доводилось работать с ним. Виктор Иванович пользовался безграничным доверием коллег, ведь он всегда старался жить для людей.

Коллектив компании “Кузбассразрезуголь», работники угольной отрасли Кузбасса и России в челом, редакционная коллегия и редакция журнала «Уголь» глубоко скорбят в связи с тяжелой утратой и выражают искреннее соболезнование родным и близким Виктора Ивановича. Светлая ему память!

\section{СУХОВ Виталий Никитович}

$$
(29.08 .1934-23.12 .2017)
$$

23 декабря 2017 г. ушел из жизни горный инженер-экономист, кандидат экономических наук, Заслуженный экономист РФ, Заслуженный работник Минтопэнерго РФ, Почетный работник ТЭК и угольной промышленности Виталий Никитович Сухов.

Богатая трудовая биография В.Н. Сухова неразрывно связана с угольной промышленностью. Окончив в 1956 г. Харьковский инженерно-экономический институт (горный факультет) и получив специальность горный инженер-экономист, Виталий Никитович начал свою трудовую деятельность в тресте «Краснолучуголь» комбината «Донбассантрацит».

Многие годы Виталий Никитович работал на руководящих должностях в Минуглепроме СССР, в ГТ «Арктикуголь» (о. Шпицберген), являлся Уполномоченным СССР в системе уполномоченных стран - членов СЭВ, избирался Председателем группы экспертов по статистике, торговле углем и транспорту ЕЭК ООН.

С 1991 по 1993 г. Виталий Никитович работал начальником отдела анализа и информационного обеспечения Корпорации «Уголь России», затем в Компании «Росуголь» - заместителем начальника Управления стратегических исследований и информационного обеспечения. С 1998 г. и до конца своих дней он трудился в НП «Горнопромышленники России» в должности директора по внешнеэкономическим связям, используя свой международный авторитет и богатейший опыт по содействию развитию экономического сотрудничества между странами-членами ЕЭК ООН.

В своей многогранной деятельности В.Н. Сухову приходилось заниматься как чисто производственными вопросами (комплексная механизация шахт, скоростная проходка выра- боток и т.д.), так и научно-исследовательскими работами, связанными с созданием и внедрением автоматизированной системы управления угольной промышленности, информационного обеспечения на базе новой вычислительной техники и др.

Виталий Никитович Сухов являлся автором более 100 научно-технических публикаций, включая 6 монографий и 9 брошюр. Он был членом ученых советов институтов ВНИИуголь и ЦНИЭИуголь, более десяти лет преподавал в Институте повышения квалификации руководящих работников и специалистов Минуглепрома СССР.

Признанием производственной, научной и организаторской деятельности В.Н. Сухова являются присвоение ему почетных званий и награждение многочисленными правительственными и отраслевыми наградами. Виталий Никитович - полный кавалер знаков «Шахтерская слава» и «Горняцкая слава».

Светлая память о замечательном, добром и отзывчивом человеке - Виталии Никитовиче Сухове - навсегда сохранится в наших сердцах. 


\section{В Мурманском морском торговом порту испытали суперсовременный вакуумный погрузчик}

В Мурманском морском торговом порту (ММТП) в середине января 2018 г. испытали суперсовременный вакуумный погрузчик.

Принципиальным отличием новейшего «вакуумного пылесоса» от аналогов является его способность создавать в рабочем органе «настоящий высокоразреженный вакуум». Кроме того, новая машина может работать круглогодично, в том числе в условиях отрицательных температур до $-20^{\circ} \mathrm{C}$.

Мобильный вакуумный погрузчик Centurion LN1012, смонтированный на грузовом шасси Volvo, произведен шведской компанией DISAB Vacuum Technology AB.

Машина предназначена для работы по уборке пыли и остатков грузов на причалах, складах, технологических проездах и дорогах.

Ширина полосы уборки составляет без малого 2,5 м, а объем контейнера для собранного материала - 12 куб. м.

Испытания показали высокую эффективность новой техники, приобретенной мурманскими портовиками в рамках масштабной экологической программы. Уже через несколько дней после успешных испытаний мобильный вакуумный погрузчик Centurion LN1012 приступил к регулярной уборке технологической площадки ПАО «ММТП».

В 2018 г. портовики планируют приобрести еще одну такую машину. Bсего же инвестиции ПАО «ММТП» в реализацию экологических проектов в наступившем году могут составить более 1 млрд руб.

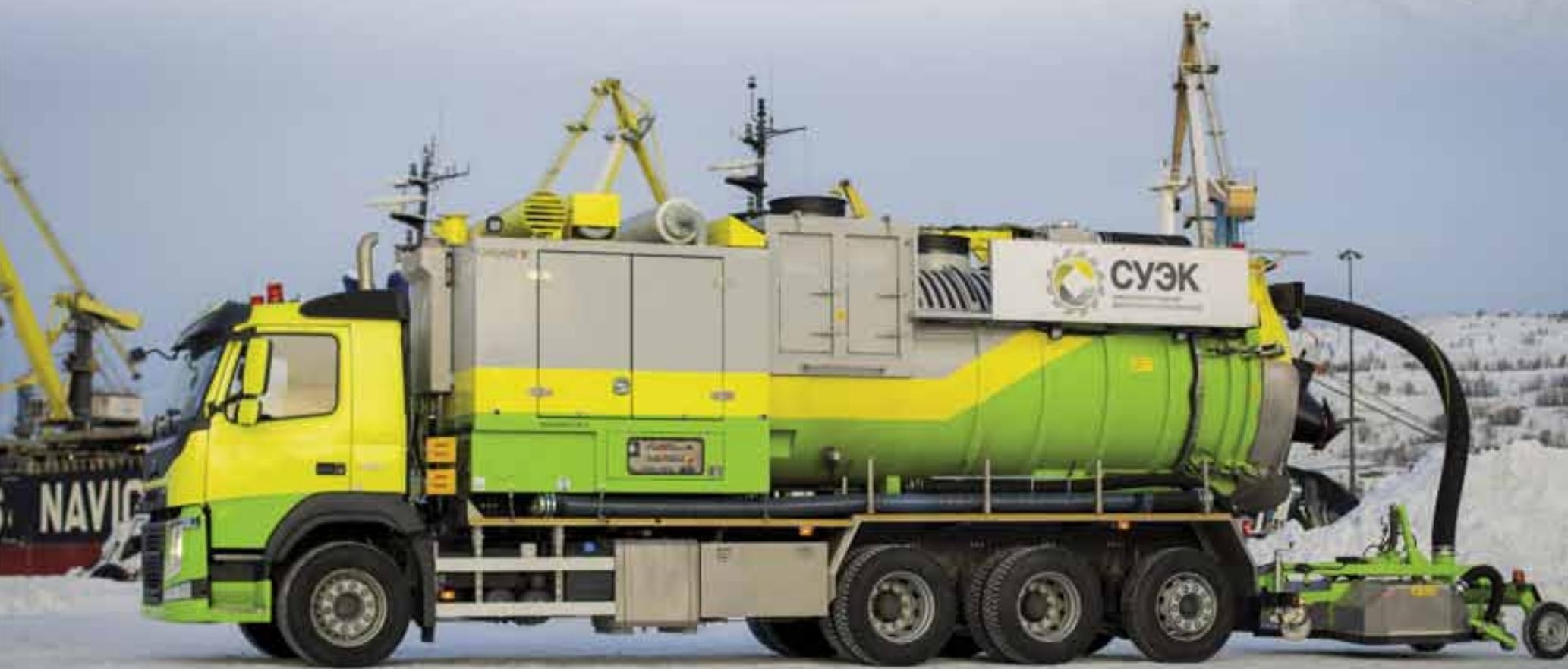


llolil

XXV Международная специализированная выставка технологий горных разработок
5-8 июня 2018 Новокузнецк / Россия
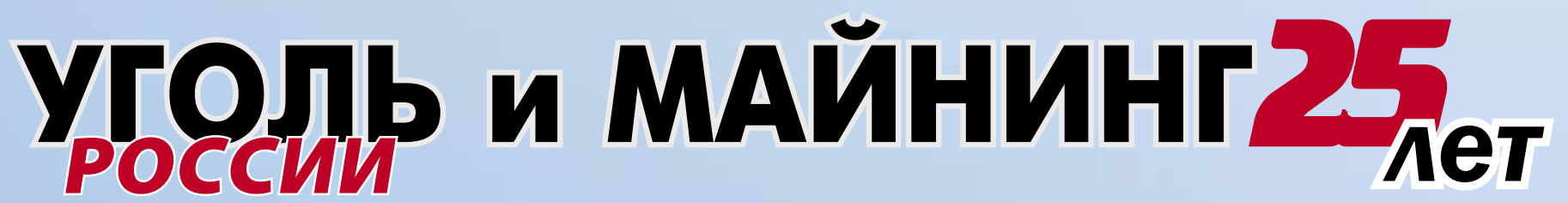

IX МежАународная специализированная выставка

\section{OXРАНА, БЕЗОПАСНОСТЬ ТРУАА И ЖИЗНЕАЕЯТЕАЬНОСТИ}

IV Международная специализированная выставка

\section{НЕАРА РОССИИ}

\section{Организаторы}
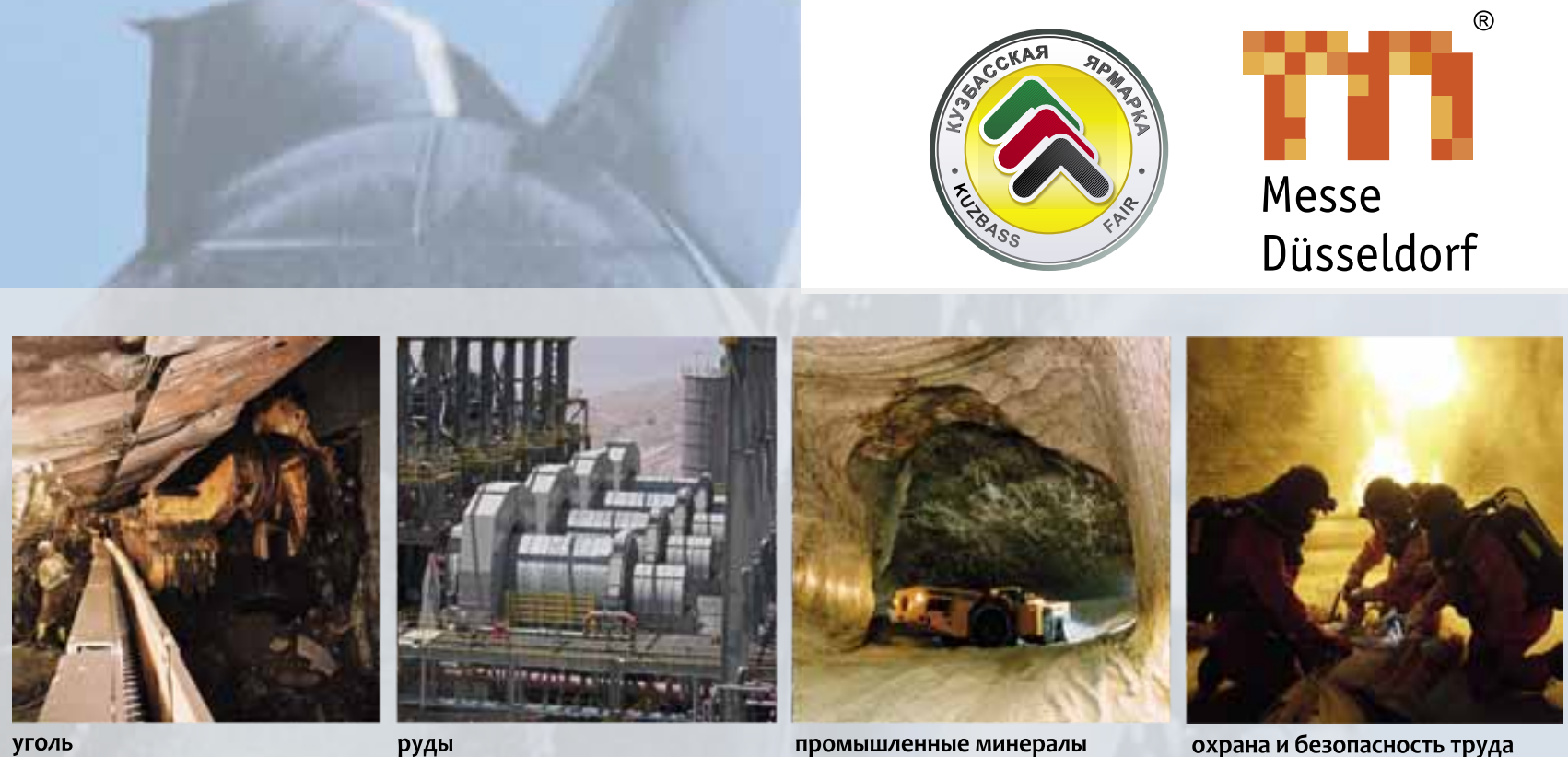

руды

промышленные минералы

охрана и безопасность труда

\section{МЕСТО ПРОВЕДЕНИЯ:}

Выставочный комплекс "Кузбасская ярмарка", ул. Автотранспортная, 51, г. Новокузнецк т./申: 8 (3843) 32-11-89, 32-22-22 e-mail: com@kuzbass-fair.ru 